\title{
The changing role of the central planning offices Latin America : a comparative historical analysis perspective (1950-2013)
}

Citation for published version (APA):

Mejia Guinand, L. B. (2014). The changing role of the central planning offices Latin America : a comparative historical analysis perspective (1950-2013). [Doctoral Thesis, Maastricht University]. Boekenplan. https://doi.org/10.26481/dis.20141119lm

Document status and date:

Published: 01/01/2014

DOI:

10.26481/dis.20141119lm

Document Version:

Publisher's PDF, also known as Version of record

\section{Please check the document version of this publication:}

- A submitted manuscript is the version of the article upon submission and before peer-review. There can be important differences between the submitted version and the official published version of record. People interested in the research are advised to contact the author for the final version of the publication, or visit the DOI to the publisher's website.

- The final author version and the galley proof are versions of the publication after peer review.

- The final published version features the final layout of the paper including the volume, issue and page numbers.

Link to publication

\footnotetext{
General rights rights.

- You may freely distribute the URL identifying the publication in the public portal. please follow below link for the End User Agreement:

www.umlib.nl/taverne-license

Take down policy

If you believe that this document breaches copyright please contact us at:

repository@maastrichtuniversity.nl

providing details and we will investigate your claim.
}

Copyright and moral rights for the publications made accessible in the public portal are retained by the authors and/or other copyright owners and it is a condition of accessing publications that users recognise and abide by the legal requirements associated with these

- Users may download and print one copy of any publication from the public portal for the purpose of private study or research.

- You may not further distribute the material or use it for any profit-making activity or commercial gain

If the publication is distributed under the terms of Article 25fa of the Dutch Copyright Act, indicated by the "Taverne" license above, 


\title{
The Changing Role of the Central Planning Offices in Latin America
}

\author{
A Comparative Historical \\ Analysis Perspective (1950-2013)
}




\section{(C) 2014 Luis Bernardo Mejía Guinand}

All rights reserved. No part of this publication may be reproduced, stored on a retrieval system, or transmitted in any form, or by any means, electronic, mechanical, photocopying, recording or otherwise, without the prior permission in writing, from the author.

ISBN 9789086663323

Published by Boekenplan, Maastricht 


\section{The Changing Role of the Central Planning Offices in Latin America A Comparative Historical Analysis Perspective (1950-2013)}

\section{Dissertation}

to obtain the degree of Doctor at Maastricht University, on the authority of Rector Magnificus, Prof. dr. L.L.G. Soete in accordance with the decision of the Board of Deans, to be defended in public on Wednesday November 19 2014 , at 14:00 hours

by

Luis Bernardo Mejía Guinand 


\section{Promoter}

Prof. dr. Mark Bevir, Berkely Political Science, USA and Maastricht School of Governance, UM

\section{Supervisor}

Prof. dr. Angelika Rettberg, Political Science, Universidad de los Andes, Bogotá, Colombia

\section{Assessment Committee:}

Prof.dr. Chris de Neubourg, Maastricht University (Chairman) Prof.dr. Martin Lodge, London School of Economics Prof. dr. Theodorus Papodopoulos, University of Bath Dr. Zina Nimeh, Ph.D, Maastricht University 
To my daughter Alicia, the joy of my life 


\section{Acknowledgements}

First and foremost, I would like to state my genuine gratitude to my supervisor Dr. Angelika Rettberg. I appreciate her involvement, contributions of time, ideas, and fieldwork funding to make my Ph.D. experience productive and motivating. The professionalism and enthusiasm she has for her own research was motivational for me, even during hard times in the Ph.D. quest.

There are many other people and organizations that I sincerely thank for their contributions to this dissertation. I am especially grateful to Professor Mark Bevir not only for taking over the formal role of promoter late in the process, but also for his time, interest, and helpful comments. Also I am thankful to Professor Chris de Neubourg for his guidance and insightful questions during the development of this piece of work. I would like to express my gratitude to Dr. Mindel van de Laar for her support in every step of my Ph.D.

I would like to thank my reading committee members Prof.dr. Chris de Neubourg, Prof.dr. Martin Lodge, Prof.dr. Theodorus Papodopoulos, Dr. Zina Nimeh for reading my dissertation and for useful suggestions and comments which helped to finalize it.

I gratefully acknowledge the funding sources that made my Ph.D. work possible. During my first 3 years I was partially funded by Universidad de los Andes, through its Desarrollo Docente program. My fieldwork was also supported by the Universidad de los Andes Political Science Department.

My gratitude is also extended to faculty members of the Political Science Department at Universidad de los Andes, whom in response both to seminar presentations and written drafts, provided helpful comments and suggestions that helped me in revising my manuscript. In particular, I would like to thank Monica Pachon and Luis Javier Orjuela for discussing my document a couple of times.

I also benefited from the comments of Miguel Gandour and his staff at Gandour Consultores, particularly Diana Rocha, Christian Cadena and Carlos Mauricio Ortiz. The stimulating environment for discussing ideas that I found among them was essential to the realization of this study.

My time at the Maastricht Graduate School of Governance was made enjoyable in large part due to the friends that became a part of my life there. I am thankful for time spent with colleagues from my 2008 cohort. Particularly, Aziz Atamanov, Sachin Badkas and Biniam Bedasso. 
My greatest debt goes to my wife Eliana Restrepo. Eliana has been essential to my completion of this study, as she has given me confidence and motivated me in so many ways. Eliana has read, discussed and improved everything I have written since we first met. For this, for her patience, support and unwavering belief in me, my deepest gratitude. 


\section{Content}





Part I. Perspectives on Central Planning Agencies in Latin America: History and Theories of Organizational Change .................................. 7

Chapter 2: The variation of the structural arrangement of the central planning agencies in Latin America ..................................................... 8

2.1 The genesis of the central planning organizations ................................. 8

2.2 The waves of change in the planning agencies ....................................... 11

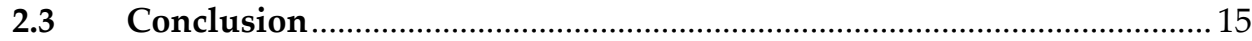

Chapter 3: Theoretical approaches …................................................ 16

3.1 Structural-instrumental perspective ………............................................... 17

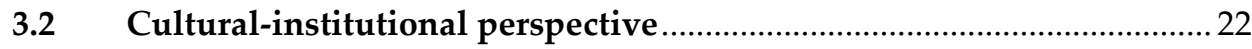

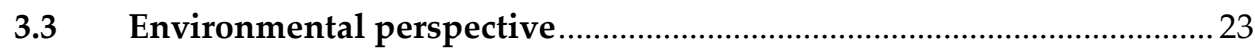

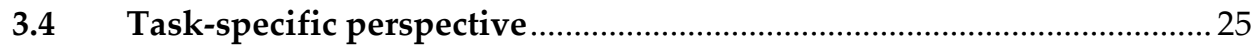

3.5 Endogenous and gradual organizational change …………………........ 26

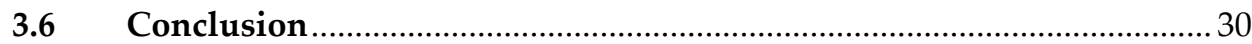

Chapter 4: Process tracing and causal mechanisms ............................ 32

4.1 Causal mechanisms in action .................................................................... 33

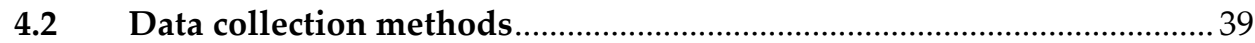



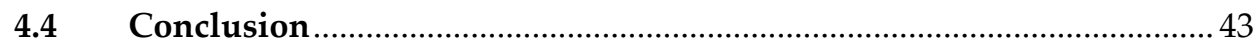

Part II. Historical Narratives: Four Case Studies................................. 44

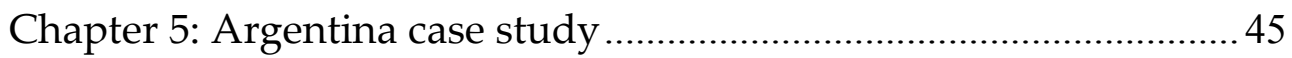

5.1 The genesis and evolution of the planning agency .................................. 45

5.2 The National Development Council-CONADE ........................................ 47

5.3 The National Institute of Economic Planning-INPE …….......................... 60

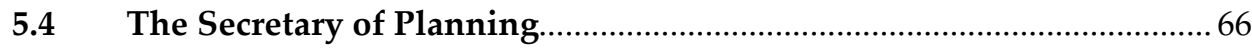


5.5 The Ministry of Federal Planning, Investment and Services

5.6 Conclusion 73

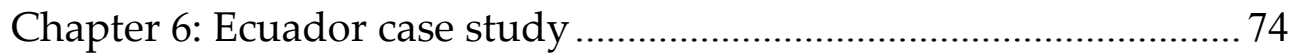

6.1 The genesis and evolution of the planning agency .............................. 74

6.2 National Board of Economic Planning and Coordination ..................... 75

6.3 National Development Council-CONADE .......................................... 86

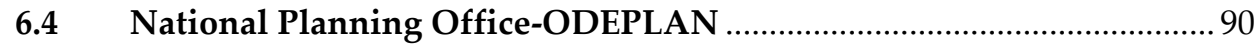

6.5 National Secretary of Planning and Development-SENPLADES........ 91

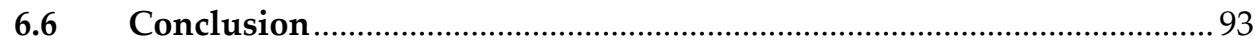

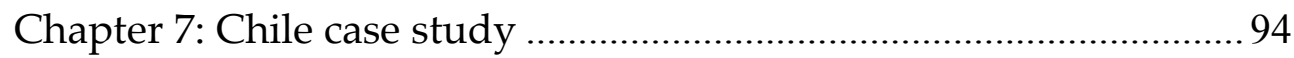

7.1 The genesis and evolution of the planning agency ............................ 94

7.2 The Chilean Development Corporation-CORFO ................................... 95

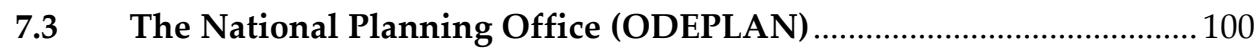

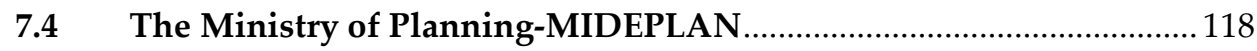

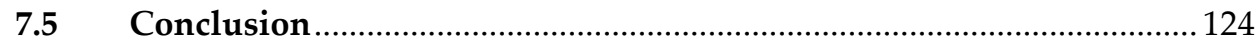

Chapter 8: Colombia case study............................................... 126

8.1 The genesis and evolution of the planning agency ........................... 126

8.2 The Department of Planning and Technical Services ........................ 128

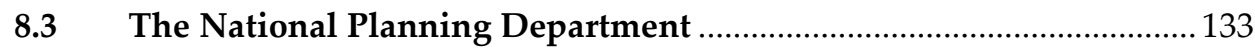

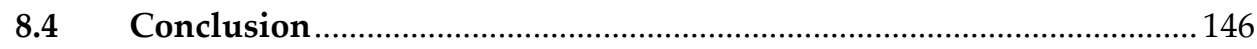

Part III. Comparative Perspectives and Conclusions....................... 148

Chapter 9: The tale of four trajectories of organizational change .... 149

9.1 Similarities and differences among case studies............................... 149

9.2 Organizational change in a nutshell: timelines of transformations ... 152

9.3 The weight of the structural-instrumental perspective ....................... 159

9.4 The weight of the cultural-institutional perspective ......................... 160

9.5 The weight of the environmental perspective ...................................... 161 
9.6 The weight of the task-specific perspective 163

9.7 Conclusion 163

Chapter 10: Explaining endogenous change ......................................... 165

10.1 Veto faculties and decree powers in Latin America .............................. 166

10.2 The ambiguity in the interpretation and implementation of the central

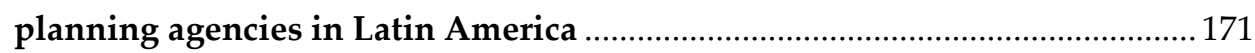

10.3 Conversion mode of organizational change ............................................ 177

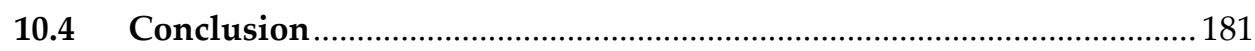

Chapter 11: Conclusions .................................................................. 182

Appendix 1: Central Planning Offices in Latin America and the

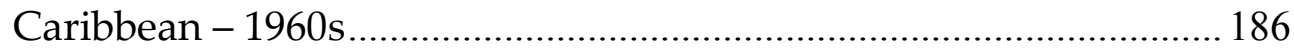

Appendix 2: Central Planning Offices in Latin America and the Caribbean - 2010 ............................................................................... 188

Appendix 3: List of secondary data reviewed ...................................... 192

Appendix 4: Historical evolution of Argentina's Central Planning Agency Tasks ..................................................................................... 194

Appendix 5: Historical evolution of Ecuador's Central Planning Agency Tasks

Appendix 6: Historical evolution of Chile's Central Planning Agency Tasks. 196

Appendix 7: Historical evolution of Colombia's Central Planning

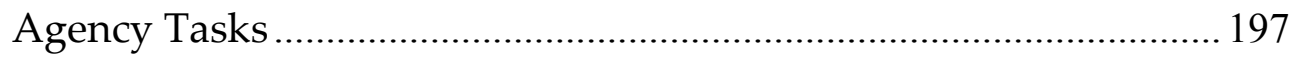

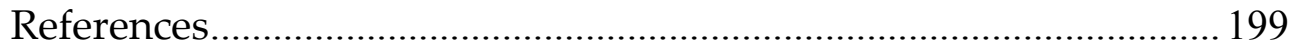

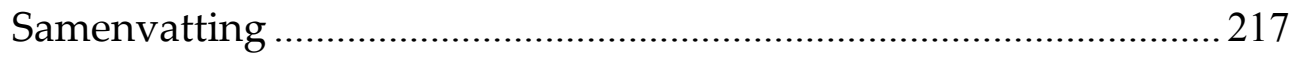

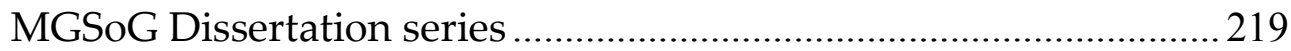




\section{List of Tables}

Table 1. Types of gradual change $\quad 27$

Table 2. Political Context and modes of institutional change 29

Table 3. Types of change agents $\quad 30$

Table 4. Causal mechanism for the structural-instrumental perspective 34

Table 5. Causal mechanism for the cultural-institutional perspective 35

Table 6. Causal mechanism for the environmental perspective 36

Table 7. Causal mechanism for the task-specific perspective 37

Table 8. Causal mechanism for the endogenous-incremental perspective 38

Table 9. Interview categories and type of questions 41

Table 10. Structural change under the Chicago Boys (first phase) 112

Table 11. Colombian National Development Plans 139

Table 12. Trajectory of the initial functions of the planning agency 150

Table 13. Political regime (1950-2013) 151

Table 14. National Development Plans during the Alliance for Progress 162

Table 15. Legal instrument underpinning the creation of the planning 168 office

Table 16. Legal instruments used to transform the planning offices 169

Table 17. Amendments to the planning agencies made by presidential $\quad 170$ mandate

Table 18. Central planning agency mandates (1960s) 172

Table 19. Examples of General and Specific Policy language 176

Table 20. Percentage of functions that fall under general and specific $\quad 177$ policy language

Table 21. The Planning Agencies and the Alliance for Progress 


\section{List of Figures}

Figure 1. Organizational Chart: ODEPLAN, 1967

Figure 2. Organizational Chart: ODEPLAN, 1970

Figure 3. Organizational Chart: ODEPLAN, 1980s 116

Figure 4. Organizational Chart: MIDEPLAN, 1990s 120

Figure No. 5. Organizational Chart: Department of Planning and 130

Technical Services, 1958

Figure 6. Organizational Chart: DNP, 1992-Present 144

Figure 7. Organizational timeline Argentina 155

Figure 8. Organizational timeline Ecuador 156

Figure 9. Organizational timeline Chile 157

$\begin{array}{ll}\text { Figure 10. Organizational timeline Colombia } & 158\end{array}$

\section{List of Graphs}

Graph.1 Fog Index applied to the mission of the planning office 


\section{List of Acronyms}

CEPLAN Centro Nacional de Planeamiento Estratégico - Perú

CONADE Consejo Nacional de Desarrollo - Ecuador

CONADE Consejo Nacional de Desarrollo de la Nación - Argentina

CONADI Corporación Nacional Indígena-Chile

CONAM Consejo Nacional de Modernización del Estado-Ecuador

CONARE Consejo Nacional de Reforma del Estado-Chile

CONASE Consejo Nacional de Seguridad -Argentina

CORFO Corporación Fomento de la Producción-Chile

DNP

DRI

Departamento Nacional de Planeación - Colombia

ECLA

Desarrollo Rural Integrado-Colombia

FOSIS

Economic Commission for Latin America

IBRD

IFIs

Fondo de Solidaridad e Inversión Social-Chile

International Bank for Reconstruction and Development (later World Bank)

ILPES

International Financial Institutions

IMF

INJ

Instituto Latinoamericano de Planificación Económica y Social

INPE

International Monetary Fund

ISI

Instituto Nacional de Juventud-Chile

Instituto de Planificación Económica-Argentina

JUNAPLA

Import Substitution Industrialization

MIDEPLAN

Junta Nacional de Planificación Económica - Ecuador

ODEPLAN

Ministerio de Planificación Nacional - Chile

ODEPLAN

Oficina de Planificación - Chile

SECPLAN

Oficina de Planificación Nacional - Ecuador

Honduras

SENPLADES

Secretaría de Planificación, Coordinación y Presupuesto -

SEPLAN

SPP

USA

WB

Secreatría Nacional de Planificación y Desarrollo - Ecuador

Secretaría de Planeación de la Presidencia - Brazil

Secretaría de Planeación y Presupuesto - Mexico

United Sates of America

World Bank 


\section{Chapter 1: Introduction}

In his annual message to Congress on May 21, 1972, Chilean President Salvador Allende said: "The people's government received a global economic planning organization (ODEPLAN) from which the government has launched its strategy to develop a planning system based on the grassroots level (...) ODEPLAN technicians have participated, along with other organizations, in planning the nationalized companies" (Allende, 1972, p 2). Three years later, in his annual message to the citizens, the then President of Chile, General Augusto Pinochet stated the following about the planning office: "by direct provision of the President of the Republic, ODEPLAN has concentrated its efforts on economic and social planning, with special emphasis on the development of the Economic Recovery Plan (...) Accordingly, to date very few companies remain under state ownership; the government has acted within the shortest time possible to transfer them to the private sector" (Pinochet, 1975, p 275). How can the same planning agency perform such contradictory functions over a period of three years? What are the conditions that have changed the design and functions of the central planning organization?

This change in function of the planning office has not been exclusive to Chile. Over the past sixty years, planning agencies in Latin America have undergone multiple transformations in their structural design. In all countries, the planning body came to life during the late-1950s in response to a development strategy that required the state to provide long-run direction to economic development by means of economic planning. Three decades later, the same agencies were reshaped, reconfigured or redeployed to serve the purposes of an entirely different development strategy. The planning body in these countries started to perform functions suitable of a free-market development model, shifting away from their prior focus on an inward development strategy. Subsequently, Latin American countries started to experience a rebirth of the state's economic presence around 2000, including a new reshaping of the economic planning agencies. In between these three distinct strategies for economic and social development, the planning agencies were continuously assigned and redirected toward a wide range of functions as seen necessary. Put simply, the central planning agencies not only emerged across time, but also evolved and shifted in gradual ways. What explains the fact that the same agency, created with the function of planning economic development, has served across time and governments with sometimes sharp ideological, economical, and political differences? What characteristics does this agency entail and which is its appeal allowing it to persist for such a long period of time? 
The underlying research in this document seeks to answer these questions by describing and analyzing the major institutional variables and actors that have influenced the changing role of Latin American central planning agencies during the last sixty years. Accordingly, the differences in the trajectories that the planning organization has followed and the variation across the four countries under investigation -Argentina, Ecuador, Chile and Colombia provide analytical leverage for disclosing the causal mechanisms that propel change.

Literature on the functioning of the public sector in Latin America centers in five branches: there is lengthy work on technocracy, particularly the debate on its autonomy from other political actors, especially its principals, IFIs and business interests (Dominguez, 1997; Montecinos, 1997, 2009; Silva, 1997; Centeno and Silva, 1998; Dargent, 2008; Schneider, 1998); numerous studies on state reform and public administration dealing with the role of the state vis a vis the economic model and diverse management models to improve state's efficiency (Haggard, 1997; Heredia and Schneider, 1998; Bresser and Spink, 1999; Nef, 2003; Weyland, 2002, 2007; Forteza and Tommasi, 2006; Lora, 2007); empirical studies on regulatory agencies (Jacint and Ramió, 2010); the impact of International Financial agencies (Haggard, 1986; Haggard and Kaufman, 1992, 1995; Haggard and Maxfield, 1996; Egan, 2010); and on building state capacity and modernization (Geddes, 1996; Grindle, 1997; Cardenas 2010). However there has been remarkable little advance in the development of research and knowledge about how the Latin American government structures have changed and adapted over time. Very few empirical studies have focused on the historical sequences of the organizational change that has supported such transformations. This research intends to contribute to filling this gap by improving the understanding of the dynamics of central planning organizational change, as well as providing insights into when and where an agency transformation might be expected.

The choice of the planning body, as the subject of study, is grounded on the fact that these agencies have had a unique position within the public sector in Latin America, becoming a real institution. Together with the central banks and ministries of finance, these three organizations have stood out as efficiency pockets vis a vis public administration; however while the first two, regardless of the economic model in place, are necessary to administer monetary and fiscal policies for macroeconomic stability, the planning body could easily become dispensable especially in light of the obvious reduction of state intervention. Contrary, the planning bodies have for an extended period of time been at the center-stage of policy-making, setting the rules for other public bureaus, many of them actually accountable to the planning agency. While typical patronage behavior has surrounded many of the public organizations in Latin America, the planning 
agencies have been significantly less affected by this phenomenon. Rather this agency has attained technical expertise and attracted highly qualified professionals.

Departing from institutionalist theories, the study presents four theoretical lenses to understanding organizational change (Verhoest et al, 2010): (i) a structuralinstrumental perspective, emphasizing formal organizational structure and the rational choice of actors; (ii) a cultural-institutional perspective, stressing organizational culture and organizational path dependency; (iii) an environmental perspective, underlining institutional environments and other elements of the politic and administrative setting; and (iv) a task-specific perspective, emphasizing the characteristics of organizational tasks to solve collective action problems. These four theoretical approaches implicitly point to distinct external inputs as forces driving organizational transformation. The cases suggest that these approaches can indeed, at certain points of time, help to explain the observed pattern of organizational change in the organization. Nonetheless, the empirical data also suggests that it is important to complement such analysis with conceptual tools that capture the logic of endogenous and gradual organizational transformation.

Following Mahoney and Thelen (2010), the study highlights that the basic properties of the planning organization provide some dynamic elements that permit transformation. In particular, the research calls attention to forms of change that are linked to two variables: veto possibilities and compliance. In this context, and in the light of the four case studies, this research shows how the weak veto possibilities faced by those attempting to change the planning agency, combined with high levels of interpretation and low enforcement of the organizations' mandates, has permitted a conversion mode of gradual and transformative organizational change, with the President singled out as the main driver of transformation.

Process tracing is used as research method. For each of the theoretical approaches mentioned, the research deducts the implicit causal mechanism linking $X$ (explanatory variable) and $\mathrm{Y}$ (organizational transformation), and empirically tests whether the observable implications were present and operated as expected (Checkel, 2005). The research understands changes in the structural arrangement of the central planning agency as all transformations in the formal structure of such organization, which might include: (i) change of functions; (ii) change of name; (iii) change of parent ministry and/or change of form of affiliation; (iv) the replacement of the planning organization by a "new" one directed at the same problem (development); (v) the termination of some aspect of the organization while the remainder continues to function; and (vi) the formation of a new planning 
organization whose purpose is closely related to the previous one, yet for which the functions and goals might be quite different (Rolland and Rones, 2009).

This method requires mapping the historical process, in this case, the events and interactions that surround the subsequent transformations of the planning bodies since their inception until present days, data that is qualitative in nature. The empirical evidence used to assess the power of the alternative explanations of organizational change in the Latin American central planning agencies is based on in-depth field research, especially elite interviews with former directors and ministers of domestic planning organization, as well as the analysis of policy documents, organizational records, historical memoirs, legal instruments and press archives.

Case studies are crucial for the present study, in terms of discovering the causal mechanisms that drive organizational change. These take the form of a detailed narrative account that purports to throw light on how an organizational change came about (George and Bennett, 2005). Four case studies are conducted covering the spectrum of positions in relation to the phenomenon of interest, in this case changes in the central planning agency. Planning agencies in Argentina and Ecuador, in tune with their countries' volatile economic and politic context experienced both, numerous abrupt transformations as well as an accumulation of more gradual transformations. Episodes of rapid change were followed by periods of ostracism. Chile and especially Colombia, present a more gradual transformation of their planning body. In Chile, the formal structure of the agency was only transformed in three occasions but the focus of the agency radically shifted across the years. In Colombia, the formal structure of the agency only changed twice over the course of sixty years but it continuously accommodated new tasks and responsibilities assigned by every incoming President.

\subsection{Outline of the dissertation}

In addition to the introduction Chapter, the dissertation is structured in three further parts. Part I of this study (Chapters 2-4) is called Perspectives on Central Planning Agencies in Latin America: History and Theories of Organizational Change. This part sets the scene and describes the prevalence, features and history of the planning organization, as well as presenting the main aspects of the theoretical lenses used in this research.

Chapter 2 provides a historical contextualization and characterization of the central planning agencies in Latin America. The Chapter briefly lays out the multiple transformations in the structural design of the Latin American central planning agencies. The section highlights how the planning body came to life in the region 
as a response to a development strategy that required state intervention by means of economic planning, while the same agency was redeployed during the course of six decades to serve the purposes of different development strategies.

Chapter 3, departing from an institutional perspective on explaining human action presents four theoretical approaches in the study of public organizations: structural-instrumental, cultural-institutional, environmental and task specific. For each theoretical perspective, the implicit force driving change is presented, namely shifts in the balance of powers among powerful actors, episodes of critical junctures, alterations in the accepted "cultural script" for what may be considered a legitimate organizational form, and changes in the economic environment that prompt organizations to reorient their basic functions. The section further elaborates that while these theories provide some insights as to the exogenous shifts that may produce discontinuous organizational changes, they fall short in accounting for endogenous sources of transformation. Therefore, they are in turn augmented with Mahoney and Thelen's conceptual tools that capture the logic of endogenous and gradual organizational change. The argument emphasizes the importance of the interaction between the political context and the characteristics of the organization as a key factor for explaining organizational gradual change.

The final Chapter of the section, Chapter 4, discusses the methodological aspects of the research, constituting the bridge between the introductory Chapters and the case studies presented in Part II. The Chapter explains the use of process tracing to account for the transformations in the Latin American central planning agencies and presents the causal mechanisms for the five theories of organizational change, as well as the observable implications to be empirically traced for. Following, the Chapter presents the research's approach to data collection, management and analysis to then address the methodological considerations of case selection.

Part II of the dissertation (Chapters 5-8) is dedicated to case studies on Argentina, Ecuador, Chile and Colombia. Each Chapter traces the creation, evolution and change over the last sixty years of the planning organization in the respective country by providing a detailed historical account of the dynamics surrounding the subsequent transformations of the planning body. The narrative accounts include secondary data as well as quotations from the various public officials interviewed. Throughout each case study, the research singles out the empirical evidence found in support of one or another causal mechanism of the alternative theoretical approaches of organizational change, assessing the explanatory power of each. 
Part III (Chapters 9-11) brings the analysis to its final stage, putting the four case studies in a comparative perspective and elucidating the main findings that account for the transformations of the planning bodies. Chapter 9 presents the core similarities and differences in each country and summarizes the organizational timeline of transformations for each of the case studies, assessing the merit of the alternative theoretical approaches to explaining the central planning organizational transformations in Argentina, Ecuador, Chile and Colombia. Here the analysis presents the shortfalls as to why the structural-instrumental, cultural-institutional, environmental, and task-specific approaches indeed each contribute to explaining specific moments of change in the central planning offices, but are insufficient to account for the entire fifty years of organizational transformation.

Chapter 10 elaborates on the research's core finding. Empirical evidence in the four cases, consistently show that the institutional trajectory and transformations followed by the planning bodies under research is best explained by what Thelen describes as a conversion mode of institutional change. The Chapter lays out additional empirical evidence on the two variables, that combined together, create the right setting for conversion to take place. The first variable is related to the role of individual or collective actors, whose agreement is necessary to change the status quo (transformation of the planning body). The second variable refers to the difficulty of putting into effect the organization's mandate, in terms of its degree of openness and room for interpretation and implementation. The Chapter describes how Latin American Presidents do not need to navigate through a large number of veto points when they wish to reorganize their administrative bureaus. Moreover, the Chapter also shows how the central planning agency was enacted in the region through vague statutes, leaving many details unspecified and thus opening the door to high levels of discretion and interpretation in formulating development policies. Presidents from these countries, pursuing their interests, frequently revised, supplemented or reinterpreted the structure and functions of the planning agency by exploiting both the low veto possibilities faced when they wanted to change the agency, as well as the ambiguities embedded in the organizations themselves, thus becoming the main source of endogenous organizational change.

Chapter 11 depicts the general conclusions of this research in terms of better understanding the dynamics of institutional change in contexts different from the advanced industrialized democracies. Findings show that institutional transformation, in the context of Latin America, alternate between gradual and abrupt transformations. The chapter also addresses the methodological limitations encountered and invites for further research on issues that require additional knowledge. 
Part I. Perspectives on Central Planning Agencies in Latin America: History and Theories of Organizational Change 


\section{Chapter 2: The variation of the structural arrangement of the central planning agencies in Latin America}

After the great depression of 1929, comprehensive development planning became accepted as a means for accelerating the rate of economic growth and breaking down structural obstacles that hindered progress. Perhaps the chief argument in favor of planning viewed it as a superior mechanism for correcting discrepancies between private and social valuations, as well as the only way to mobilize resources on the scale necessary for a successful development effort. It was thought that national planning would permit setting up a coherent framework for public resource allocation and the establishment of guidelines for decision making by public and quasi-public agencies concerned with national development (Rondinelli, 1978).

Latin America became part of this trend throughout the 1930s, with different countries of the region beginning to switch their development strategy based on a commodity export-led model to a new approach that relied on state-led efforts to construct basic industry, develop infrastructure and build domestic manufacturing. This inward growth model, called Import Substitution Industrialization (ISI), gained a theoretical foundation in the 1950s, when the United Nations Economic Commission for Latin America (ECLA) suggested that developing countries should attempt to reduce their foreign dependency through state-induced industrialization, governmental spending and planning (Iglesias, 2006; Moreira 2008; Bresser, 2009). This Chapter presents a historical contextualization of the central planning agencies in Latin America, detailing the multiple transformations in the structural design of the Latin American planning bodies.

\subsection{The genesis of the central planning organizations}

Following ECLA, Latin American governments adopted a series of measures that included high import tariffs, multiple exchange rates, exchange controls and quotas (Cardoso, 2009). These measures substantially increased the price of imported goods with the aim of fostering national industrial growth (Sapelli, 2003). According to ECLA's view, government's principal task was to provide long-run direction to economic development by means of economic planning. Therefore, one of ECLA's main recommendations was the adoption of a long-term development policy in the region, along with the creation or strengthening of central planning agencies (Iglesias, 2006; Leiva, 2010). 
This idea was reinforced in 1961 when President Kennedy proposed a ten-year plan for Latin America, known as Alliance for Progress (Garcia, 2008; Leiva, 2010). The program called for an annual increase of $2.5 \%$ in per capita income, the elimination of adult illiteracy, the establishment of a land reform agenda and the adoption of economic and social planning, among other things (Taffet, 2007). In addition, the program required participating countries to draw up comprehensive plans for national development as a prerequisite for receiving economic aid. The charter was signed by twenty Latin American nations at an inter-American conference at Punta del Este, Uruguay (Taffet, 2007; Leiva, 2010).

Almost all Latin American governments embraced planning as an instrument for bringing about necessary structural changes, but most importantly as a tool for mobilizing national resources and qualifying for international aid under the Alliance for Progress. In support of this effort, ECLA created the Latin American Institute for Economic and Social Planning (ILPES) in 1962, with the purpose of supporting the Latin American Governments in the area of planning through the provision of training, advisory and research services (ILPES, 2013).

Since its inception, ILPES advocated the establishment of central planning offices. One of the key recommendations of ECLA-ILPES's 1962 Latin American Seminar on Planning was to set up a central planning office within the government structure (Waterston, 1966). Following ECLA's suggestion, those Latin American countries that had not yet established their central planning agencies during the 1950s created them throughout the 1960s, while other countries strengthened their existing ones. Appendix 1 lists the central planning offices that existed in Latin America and the Caribbean during the 1960s.

There was a notable variety in the structural arrangement of the agencies. Eight of the twenty-three countries (Uruguay, Honduras, Guatemala, El Salvador, Ecuador, Dominican Republic, Cuba and Argentina) adopted a collegial body (commission, board or council) as the organizational form for their planning offices. The collegial body consisted of five to seven members, who tended to represent several of the economic-related ministries. Commissioners were appointed by the President and the functions of the organization were normally advisory in nature. In six countries (Chile, Costa Rica, Panamá, Trinidad and Tobago, Venezuela and Nicaragua), the planning agency was an administrative unit within the internal organization of the executive office of the President. In four states (Brazil, Colombia, Mexico and Paraguay), the planning office took the form of a ministry, whereby the minister of planning was appointed by the President and had responsibility for one or more agencies or other administrative organizations. In one country (Barbados), the 
planning body was located as an administrative unit ${ }^{1}$ within the internal organization of the Finance, Economy or Development ministries. Finally, four countries (Bolivia, Haiti, Jamaica and Peru) developed their central planning office as an administrative agency.

Regardless of the specific structure given to central planning offices, whether a collegial body or ministry, the different countries shared a view of the planning agency as a central organization meant to work across government departments or ministries to provide advice to the President on economic development, as well as ensuring policy coherence and coordination on his behalf. The central planning agencies had either formal or informal authority over other departments, ministries and administrative agencies and often directed their actions. In many cases, planning sub-units were created within the jurisdiction of the ministries and administrative agencies, holding the duty of helping these organizations to define their sectoral development targets and plans. In this sense, the planning body differentiated itself from other public organizations because, in principle, it did not involve the representation of particular interests. The planning agency was concerned with the formulation of development and economic policy for the state as a whole, as opposed to the representation of one segment of the economy or substantive area.

The planning bodies were in charge of (i) advising the executive in the preparation of the National Development Plans based upon macro-economic analysis and econometric models; (ii) assisting the President on economic matters; (iii) coordinating the development activities of line ministries and administrative agencies; and (iv) conducting studies concerning the national economy (Waterston, 1966). Seven main functions have been present in these agencies across time and across countries: budget assignment and prioritization; the regulation of economic sectors; macroeconomic forecasting and planning; policy agenda setting; state and public administration reform; the administration of external credit financing; and the coordination of policy design and implementation, both across public entities of the central and decentralized level and with the private sector.

In almost all countries, these functions assumed by the central planning offices were supported by the more competitive recruitment of specialists in the planning agencies and the appointment of experts in key positions of economic policy. As Barbara Geddes (1990) pointed out, the organizations in charge of economic policy making (ministry of economy, central bank and planning agency) in many Latin American countries were isolated from customary political patronage networks.

\footnotetext{
${ }^{1}$ An administrative unit was a low-level division with administrative responsibilities inside an agency, ministry or other administrative organization.
} 
This fact contributed, "first, to the concentration of expertise in these organizations, since jobs are not traded for support; second, to a more efficient concentration of scarce resources on chosen development goals, since contracts and subsidies are not exchanged for support; and third, to greater agency commitment to bringing about change, since the careers of individual bureaucrats depend on achieving goals rather than demonstrating partisan loyalty" (Geddes, 1990, p. 218).

This phenomenon gained widespread visibility in Latin America after the 1960s, following the onset of military rule in Brazil, Argentina, Chile and Uruguay. These governments, typified by Guillermo O'Donnell as bureaucratic-authoritarian regimes, were characterized by the exclusion of organized groups, political parties and Congress on economic policy making, as well as the faith in technical solutions thought as "apolitical" to solve national problems (O'Donnell, 1973; Silva, 1997). Subsequent studies of technocracy in Latin America indicate no substantial change to this approach (Montecinos, 1993; Grindle, 1996; Silva, 1997; Centeno, 1998; Palacios, 2001; Wise, 2003; Montecinos and Markoff, 2009). According to these scholars, elected executives have continued to monopolize economic management, relying on small groups of experts who formulate policies without systematic consultation with political parties, Congress or organized groups.

Furthermore, the University of Chicago's involvement in the "modernization" of its Latin American counterparts encouraged the idea of building up a technical knowledge, based on economic liberal ideas, and technocratic organizations that made government policies adequate (Montecinos, 1993). This point is illustrated by the creation of the Center for Latin American Studies at the University of Chicago, financed by the Ford Foundation, as well as the relationship between the Catholic University of Chile and the Chicago University. The Chilean experience was replicated in other Latin American countries, particularly in Argentina, Brazil and Mexico. As a result, a more competitive recruitment of experts and the appointment of technocrats in key positions of the economic policy making began to mark Latin American public sectors. One such example was the advent of the so-called Chicago Boys in Chile in 1974 (Valdes, 1995).

\subsection{The waves of change in the planning agencies}

By the mid-1970s, many Latin American governments had shifted their planning activities from macro-economic modeling to project approach. This method required the central planning agencies to compile and review the investment proposals of national ministries, local governments and semi-public corporations, allocating the capital budget to them based upon the centrally determined economic priorities. Moreover, many central-planning agencies assumed direct interference on policy decisions related to the prioritization of foreign financing 
and industrial protection policies during this period (Rondinelli, 1978). For example, in 1966, the Colombian planning agency started to favor well-prepared projects instead of macroeconomic forecasts (Urrutia, 1988). In the same direction, the Chilean planning office shifted emphasis from macro (input-output) planning to project appraisal (World Bank, 2006).

Following this trend, Brazil restructured its Ministry of Planning and Coordination in a Secretariat of Planning of the Presidency (SEPLAN) in 1974, assigning it executive functions and the responsibility for all economic decisions. ${ }^{2}$ In the same year, Costa Rica issued its planning Law (Law $\mathrm{N}^{\circ} 525$ ), through which the National Planning Office was granted the budgetary function of defining the national investment project. ${ }^{3}$ During the same period, Panama established the Ministry of Planning and Economic policy (Law $\mathrm{N}^{\circ} 16$ ) with a budgetary role. Finally, the Secretariat of Programming and Budget (SPP) came into existence in Mexico in 1976. By the late-1970s the central planning agencies of Venezuela, Peru, Uruguay, Costa Rica, Dominican Republic, Nicaragua and Honduras also started to prepare the capital budget, in coordination with the Ministry of Finance, or began to supervise the execution of the development plan through the appraisal and approval of all public investments.

During the early-1980s, the import-substitution industrialization model in Latin America was reaching its limits, with its political support gradually eroding:

Not only the size of Latin American domestic markets constrained the opportunities for further industrialization, but also the accumulation of distortions associated with the panoply of government interventions imposed a growing "drag" on the growth prospects of these economies. Moreover, monetary and fiscal profligacy often became the macroeconomic companions of ISI, as governments tried to stimulate economies amid growing signs that the growth dividend of the "easy" ISI phase was gone. These actions paved the way to the growing external debt and balance-of-payment crises experienced by Latin American countries in the 1980s. ${ }^{4}$

The so-called lost decade was characterized by massive foreign debt and macroeconomic problems (especially inflation and fiscal deficit) that occurred

\footnotetext{
${ }^{2}$ See http://www.planejamento.gov.br/

${ }^{3}$ See http://www.mideplan.go.cr/

4 Primo Braga, Carlos (2006) "Import Substitution Industrialization in Latin America: Experience and Lessons for the Future". Paper prepared for a seminar in honor of Professor Werner Baer, held at the University of Illinois at Urbana-Champaign, December 1-2, 2006
} 
during the transition to democracy. While military regimes were the norm in the 1960s and 1970s (Colombia, Costa Rica and Venezuela were the exception), during the 1980s authoritarian rule was confined to four countries: Bolivia, Haiti, Guatemala and Paraguay (Valenzuela, 2004). In face of the aforementioned situation, namely fiscal and inflationary problems, some countries withdrew executive economic functions from the central planning agencies, transferring them to the ministry of finance, while other countries favored short-term economic measures led by their planning offices. In Brazil, Peru and Argentina, the central planning agencies (SEPLAN, National Planning Institute and Planning Secretariat respectively) were relegated to background coordination functions, while the ministry of finance in each country was assigned with all of the important shortrun economic decisions such as dealing with the inflation and debt crises, which resulted in the Cruzado, APRA and Austral Plans, respectively. Meanwhile, countries such as Mexico, Colombia, Chile and Costa Rica empowered their planning agencies with the task of improving the quality of government decision making in areas of public investment, economic policy, foreign aid and credit.

Throughout the late-1980s and early-1990s, the fundamental premise of Import Substitution Industrialization as a growth strategy was completely substituted in the region by the principles of market forces and state retrenchment. Following the Chilean experience, a number of Latin American governments implemented measures based on control of the fiscal deficit, including tax reforms, the liberalization of trade, financial markets, interest and exchange rates and the reduction of the state's size and role. ${ }^{5}$ While the central planning agencies were the natural candidates to disappear in this context of pro-market and multilevel planning public sector reforms, they persisted in the region, with the exceptions of Mexico, Peru, Honduras and Panama. Mexico turned off its Secretariat of Programming and Budget in 1992, transferring many of its functions to the Secretariat of Finance. Peru deactivated its central planning office (National Institute of Planning) in 1992 under the state modernization reforms followed by the Fujimori's government, while Honduras disengaged its office (SECPLAN) in 1996. Finally, Panama merged the Ministry of Planning with the Ministry of Finance in 1998, creating the Ministry of Economy and Finance.

During the 1990s, the so-called neo-liberal changes helped to strengthen some of the functions that central planning offices had been performing, as well as adding new administrative reorganizations. Capabilities for project appraisal and the prioritization of public investment, functions that had been assumed by many planning agencies during the 1970s, were now reinforced as a requirement for the

5 Venezuela 1989-1994; Mexico 1988-1994; Bolivia 1985-1989; Argentina 1989-1999; Peru 1990-2000; Nicaragua 1990-1997; Brazil 1990-1994; Colombia 1991-1994. 
implementation of structural adjustment programs. At the same time, tasks related to negotiating international cooperation and, to a lesser extent, dealing with the public sector restructuring, started to appear as a mandate of the planning agencies. For example, Chile transformed its planning office (ODEPLAN) into the National Ministry of Planning and Cooperation (MIDEPLAN), allocating it the new responsibilities of handling international cooperation and coordinating poverty reduction programs. In Costa Rica, the National Ministry of Economic Planning (MIDEPLAN) assumed functions related to state modernization and international cooperation.

Throughout the 2000s, Latin American governments that had come to power in the 1990s, and in many cases favored pro market policies, started to be replaced by administrations leaning to the left (Maxwell, 2009). Candidates from the left have emerged triumphant in Argentina, Bolivia, Brazil, Chile, Ecuador, Guatemala, Honduras, Nicaragua, Paraguay, Uruguay and Venezuela. Regardless of the ideological affiliation, Latin American governments are bringing the planning agencies back yet again. This trend responds to attempts to better integrate the planning process with the budgetary process, or to an effort to exercise the government's greater intervention in the economy. In this context, Peru reactivated its central planning agency in 2005 with the creation of the National Strategic Planning Center (CEPLAN). In 2004, Ecuador transformed the old Planning Office (ODEPLAN) into the National Planning and Development Secretariat (SENPLADES), assigning it a predominant role in the budgetary process. Bolivia restructured the Ministry of Sustainable Development into the Ministry of Development Planning in 2006, with the task of being the main governing body of the National Planning and Public Investment Systems. Argentina reorganized its Planning Secretariat into the Ministry of Federal Planning, Investment and Public Services, assigning it regulatory functions in transport, mining, communication and energy policies. Finally, Brazil assigned the Ministry of Planning and Management the tasks of monitoring and evaluating the public investment in 2000.

Appendix 2 shows the central planning offices that currently exist in Latin America and the Caribbean, along with all the subsequent organizational changes that each of the agencies have faced across time. Sixteen out of twenty Latin American countries have central planning offices in place. Unlike the 1960s, when there was a wide variety of organizational arrangements among the planning offices, today there is greater homogeneity. Ten out of sixteen countries (Argentina, Bolivia, Brazil, Chile, Colombia, Costa Rica, Cuba, Dominican Republic, Haiti, Uruguay and Venezuela) have adopted the figure of ministry as the preferred structural arrangement for the planning office, while four nations (Ecuador, Guatemala, Paraguay and Uruguay) have created their planning agencies as a technical entity 
under the Presidency of the Republic and two (Nicaragua and Peru) states have arranged their central planning agency as a collegial advisory body (commission, board or council). These figures indicate that $87.5 \%$ of planning entities in Latin America are currently under direct influence of the President.

During the last sixty years, the Latin American central planning organizations have resisted ideological fluctuations, successive fiscal adjustments and unexpected changes of government. Some countries celebrated the fiftieth anniversary of these organizations; for example, Chile and Colombia published commemorative books with the history of their agencies, as well as the issue of a memorial stamp in the case of Colombia, while Costa Rica hosted a gala at the National Theatre in the capital San José, in an event attended by President Laura Chinchilla.

\subsection{Conclusion}

This section has examined the historical context in which the central planning agencies emerged and evolved in Latin America, presenting how these agencies were reshaped and reconfigured over time in the Latin America's public sector. Indeed, these transformations triggered changes in the structure and operation of the agencies, ranging from performing functions related to a strategy of import substitution industrialization to accomplishing tasks linked to an export-oriented development model. Furthermore, the section has also stressed how the location of the planning agency inside the structural arrangement of the state has tended to move closer to the President during recent decades. The next Chapter presents the main theoretical approaches from which the observed pattern of organizational change can be explained. 


\section{Chapter 3: Theoretical approaches}

Following Parson (2007) all explanatory arguments about human action, in general and political action, in particular, can be broken down into four categories: structural, ideational, psychological, and institutional. Each of these positions provides distinct ontological presuppositions about the way in which the world is constructed.

First, under the logic of the structural framework what people do, or are constrained to do, is a function of their position vis a vis exogenously given material structures (e.g. geography, distribution of wealth, and distribution of physical power). In other words, structural claims explain how certain preferences and given material structures dictate observed behavior. According to Parsons (2007) for structure to have any impact, actors have to react in a rational way to their structural position, which is not alterable by people. In this context, entities exist and function, not in terms of their own inherent properties, but rather in relationship with other entities, much more in the sense of how the part fits and relates to the whole Lichbach $(1997,246)$.

Second, the ideational category explains what people do, as a function of cognitive and affective elements, and how they organize their thinking, and therefore their world. Here, the focus is on how ideas matter in ways that cannot be reduced to the objective position of an actor. According to Parsons (2007: p131), "ideational causal claims trace actions to some constellation of practices, symbols, norms, grammars, models, believes and identities through which certain people interpret the world. For these ideational elements to gain autonomy as distinct causes of action, the must be the consequence of earlier contingent actions".

Third, Parsons (2007: p12) states that "psychological claims explain what people do as a function of the cognitive, affective, or instinctual elements that organize their thinking, but see these elements as general across humankind". This category deals with mental rules that are hardwired into human brain, resulting in behavioral regularities.

Fourth, the institutional approach claims that what people do is a function of their position within man-made, therefore adaptable organizations and rules. It is possible to identify three main institutional schools. The first one is the rational institutionalism, which emphasizes methodological individualism, whereby the understanding of social phenomena departs from the motivations and interests of individuals. Put simply, individuals are rational entities in search of maximizing their utility through a process of strategic interactions that allow the individual to 
rank and sort out its preferences. Scholars that work in this perspective include Williamson, 1975; Moe, 1984, 1990; Weingast and Shepsle, 1981. The second one is sociological institutionalism that sees institutions affecting action through a dynamic of legitimacy or appropriateness. People behave in patterned ways in line with organizational models, rules, and informal roles. Powel and Dimaggio (1983) follow this line of research. The third one is historical institutionalism, which conceptualize mechanisms in ways that capture the unforeseen consequences of earlier choices, prioritizing the building blocks of path dependency and temporal effects. Mahoney and Rueschemeyer (2003) and Skopol (1995) are good examples.

Out of these four explanatory arguments to explain human action, this research uses the institutional approach, mainly because it understands the central planning agencies as institutions. This Chapter outlays the core ideas of four different theoretical institutional perspectives in explaining organizational change which stress the importance of external pressure. Following Verhoest et al. (2010), institutional explanations as to why agencies are created and change can be classified based on two major logics of action: first, under the logic of consequentiality, organizations are used by actors as instruments to pursue specific goals; and second, the logic of appropriateness considers public organizations as driven by rules of proper or exemplary behavior. Organizations are created or changed because they are seen as modern, rightful, expected and legitimate. Keeping these two logics of action in account, Verhoest et al. (2010) distinguish four different theoretical perspectives

1. A structural-instrumental perspective that originates from the rational institutionalism school, emphasizing formal organizational structure and the rational choice of actors.

2. A cultural-institutional perspective that follows from the historical institutionalism school, emphasizing organizational culture and organizational path dependency.

3. An environmental perspective that originates from the sociological institutionalism school, emphasizing institutional environments and other elements of the politic and administrative setting.

4. A task-specific perspective, which also originates from the rational institutionalism school, emphasizes the characteristics of organizational tasks to solve collective action problems.

\subsection{Structural-instrumental perspective}

According to this theoretical lens, public organizations emerge and transform out of political conflict and strategic bargaining between rational actors or coalitions. In this sense, choosing differentiated organizational forms for public 
administration is not only a management tool or an instrument of improved governance, but also a political action. Therefore, variations in administrative design across agencies result from rational actors' efforts to optimize expected benefits from the administrative design.

The bulk of this tradition looks at organizational design through a focus on congressional delegation (Lewis 2003). Legislators prefer to delegate policy making authority to bureaucrats (executive) when they feel that delegation will increase their electoral opportunities relative to policy making in Congress; namely, when the policy in question has concentrated benefits and disperse costs or when unpopular policies need to be enacted (delegation is aimed at reducing legislative decision making costs). On the other hand, Congress prefers to make policy itself when the opposite is true (Weingast, Shepsle and Johnsen, 1981; Fiorina, 1982; Horn, 1995; Epstain and O'Halloran, 1999; Lewis, 2003).

However, legislators face a set of problems when delegating authority: how can they persuade bureaucrats to comply with their wishes? Moreover, what should they do when subsequent political coalitions want to change the actual legislation? These two forms of strategic behavior are labeled as bureaucratic and legislative drift.

McCubbins, Noll and Weingast (1987) focus on the problem of encouraging bureaucracies to comply with intentions of elected politicians and how administrative structure and procedures might constitute a solution to this problem. According to McCubbins, Noll and Weingast (1987), bureaucratic drift is a restatement of the classic principal-agent problem. There will always be a tension between the efficiency gains that the delegation provides and the risk that bureaucracies will expropriate these efficiency gains for themselves. Politicians address the bureaucratic drift by changing the procedural rules to which administrative agencies are subject. These procedural rules will create a set of conditions that prompt the agency to generate the policy outcomes that the enacting coalitions want to reach. One of McCubbins, Noll and Weingast's main arguments is that the most effective mean for achieving political control of an agency is establishing ex-ante constraints on its flexibility (restricting the agency's decision making before it actually makes policy choices), rather than reliance on ex-post punishment or oversights. In other words, writing into the law precisely what the agency is to achieve, as well as how it is to do so.

On the other hand, Horn and Shepsle (1989) emphasize that the enacting coalition must not only worry about shirking by the bureaucrats within the agency, but also from the future influence of subsequent political coalitions on the development 
and administration of the law. In order to avoid legislative drift, the enacting coalition influences the costs that subsequent coalitions must incur to modify a deal. In these terms, legislation can be designed to make it difficult for later coalitions to affect the future stream of benefits and costs. Horn and Shepsle (1987) pose that these considerations are likely to influence the enacting coalition's choice of the structure of the public organization that will administer a policy (regulatory commission, state-owned enterprise or administrative agency). These alternative organizational forms vary in the extent to which they are independent from the influence of subsequent coalitions. Therefore, the legislative enacting coalition raise the transaction costs of changing an agency, when they have policy disagreements with other actors that are in a position to influence agencies in the future (Horn, 1995; Epstein and O'Halloran 1999; Huber, Shipan and Pfahler 2001; Huber and Shipan 2002; Wood and Bohte 2004). In other words, legislative coalitions design agencies to insulate policy bargains from future influence.

Here, the formal structure of the organization not only determines whether and how agencies may be controlled, but also the way in which the agency will obtain the desired results. As Macey (1993, p. 93) notes, the "politicians who establish administrative agencies can manipulate the structure and design of those agencies in ways that reduce the chances that future changes in the political landscape will upset the terms of the original understanding among the relevant political actors". There are different ways in which politicians insulate the public organization that they care about, with the literature mentioning, among others, the following:

Location: refers to the organization's proximity to the President. Public organizations that have close proximity to the President are more susceptible to be changed, while distance from the President should render an organization less vulnerable to be controlled (Epstein and O'Halloran, 1999; Boin et al, 2010). According to Lewis (2003), Congress chooses to set organizations outside the office of the President or cabinet as a way of protecting the agencies from presidential influence. For instance, Presidents exerts less control over independent administrations, boards or commissions than on cabinet departments. In this sense, the literature supposes a positive relationship between the structure as a board or commission and the organization's longevity (Horn, 1995; Epstein and O'Halloran, 1999; Lewis, 2003; Wood and Bohte, 2004).

Hierarchical independence: relates to the organization's formal position vis-a-vis other organizations. Whether an agency is placed within or outside existing organizational structures will affect its survival prospect. According to the literature, organizational independence (not established as a subdivision of an 
existing public organization) will increase the agency's life span (Lewis, 2003; Boin et al, 2010).

Appointment: it deals with the rules to appoint and dismiss the head of the organization. The organization's level of protection is influenced by whether the director of the organization is directly appointed by the President without any specific limitations or if the agency's director is chosen by a board or commission.

To summarize, following the logic of consequentiality, the structural-instrumental approach focuses on formal agency structure, assuming that rational politicians purposefully design agencies in order to maximize their utility. In this perspective, there are three actors: interest groups, politicians (legislators) and bureaucrats. Legislators and their constituencies (interest groups) engage in a transaction in which the former want electoral support while the latter seek private benefits (or reduced private cost) of legislation. According to Moe (1989; 1990a; 1990b) and Yelsilkagit (2004), in this relationship interest groups are the actors that are truly concerned about issues pertaining to the organizational structure (should the organization be part of a ministry or independent, etc.). In this sense, interest groups will push legislators to establish administrative agencies with certain structural design to reduce the possibilities of future organizational change. The third and final main actor is the bureaucracy. Bureaucrats and legislators also engage in a transaction in which the latter delegate authority to the former in order to implement a piece of legislation. Bureaucrats implement the legislation through organizational designs, while legislators seek to influence how administrators exercise their discretion. Accordingly, legislators strategically attempt to manipulate administrative design attributes to prevent losses due to drift during policy implementation.

Thus far, legislators have been at the center of attention in this approach concerning administrative agency design. The role and power of Congress in specifying agency design as well as legislators' attempts to control and isolate administrative structures has been predominant. Public organizations are seen almost as an extension of the legislature. In this sense, Congress has the final decision over which agencies are created, what functions they perform and how they are designed (Macey, 1992; Horn, 1995; Epstein and O'Halloran, 1999). This methodological bias towards Congress has prompted some to assume that Congress dominates the politics of agency creation and change, ignoring the unique incentives the President has on agency creation (Lewis, 2003).

One important exception to this line of research argues that the administrative design of public organizations cannot be understood without a good knowledge of 
the influence of the bureaucracy and the President. Moe (1989, 1990a, 1990b), Moe and Wilson (1994), Howell and Lewis (2002) and Lewis (2003) argue that administrative agencies are the result of bargaining between the President and Congress, with the President therefore having a direct influence on agency design. In Moe's work, the role of the President is analyzed in terms of his efforts to oppose attempts by Congress to insulate administrative agencies. "The President takes advantage of collective action problems in Congress, unilaterally creates agencies that are not insulated, and uses other formal powers to persuade Congress to do likewise" (Lewis, 2003, p.15). Building on Moe's insights while closing the gap left by Moe's work, Howell and Lewis (2002) and Lewis (2003) present and test a theory of executive influence in agency design, using quantitative data collected on administrative agencies created in the United States between 1946 and 1997.

Lewis (2002) shows how Presidents, when unable to convince Congress to build an administrative agency, can influence the design of such organizations through their legislative power of veto, their position as a chief executive and their authority to create administrative agencies through executive action (executive orders, departmental orders, reorganization plans). Presidents devise these organizations in ways that take full advantage of their control over them.

One of Lewis's main findings is that Presidents are more prone to creating agencies during periods when the congressional majority is weak, implying that they use the weakness of Congress to establish their preferred types of agencies (Lewis, 2003). Howell and Lewis (2002) highlight that Presidents create fewer administrative agencies when Congress is strong. Furthermore, Lewis finds that Presidents exercise more control over the agencies that they create through unilateral directive than those that Congress and President establish through legislation. By contrast, Lewis discovers that agencies that are insulated from presidential influence are more likely to survive than other agencies (for instance, those created by executive orders). All such findings suggest that institutional factors that undermine Congress augment presidential willingness to create administrative agencies. Nonetheless, Congress continues holding a key strategic advantage in this literature. If a President establishes an agency that members of Congress do not like, they can simply cut off funding. Therefore, Congress continues to have a proactive role in agency design.

These insights concerning the President's role in the creation of administrative agencies has been very helpful in developing a more complete and testable theory about the process of agency design. However, information is still required on the role of the President in contexts in which their power to unilaterally create 
administrative agencies is proactive and not reactive against the power of Congress. Moreover, despite the importance of information about the moment of the agency creation, empirical data about the historical transformation of the agencies and the role of the President in such changes is still required.

\subsection{Cultural-institutional perspective}

This perspective focuses on organizational culture and organizations as institutions (Verhoest et al, 2010). In this literature, organizational forms reflect shared cultural understandings of what is modern, legitimate or efficient (Thelen, 2003). In the same way, "action is regarded as being based on prevalent norms and values rather than goals, and in accordance with logic of appropriateness rather than with logic of consequentiality" (Verhoest et al, 2010, p. 34). This means that decision makers act in accordance with their experience of what has worked well in past or what is considered acceptable in the environment in which the person works (Laegreid and Verhoest, 2010).

Organizational culture is the set of shared values, identities and norms that control organizational members' interactions with each other, as well as other people and organizations outside the agency (Jones 2010). Like structure, culture may constrain and enable what organizations and its members do. However, unlike the structural approach, in which organizations are important in an instrumental sense, under the cultural approach, an agency becomes a value-bearing institution with its own separate identities and judgments concerning the relevant troubles and solutions (Verhoest et al, 2010).

Organizational culture shapes and controls behavior within the organization, influencing how people respond to a situation and interpret the environment surrounding the agency (Wilson, 1989). Therefore, through mechanisms of socialization, organizational culture strengthens cohesion and commitment among its members, while also demarcating organizations from one another. Organizational culture impresses members of the agency with a sense of belonging to a community with shared goals, norms, working language and mission, which are taught to new organizational affiliates.

According to Verhoest et al (2010), path dependence is a central concept in the political science literature on the institutionalization of cultural organization. From this perspective, some organizations can achieve an initial advantage over alternative organizations and succeed, despite the fact that the alternatives would have been more efficient in the long run (Thelen, 2003). Once a set of organization is in place and into a stable trajectory, political actors adapt their strategies to 
accommodate the prevailing pattern in ways by which preceding steps in a particular direction induce further movement in the same direction. Through these developments, the initial choice becomes locked in, making it hard to shift from the chosen institution to another. Peters (1992) refers to this as a "competency trap", which emerges when an organization appears to be competent at what it does and institutionalizes certain means of achieving its ends. By doing so, Peters stresses that the agency ignores the possibilities to respond in other ways that might be more efficient or effective.

According to North (1990), this pattern occurs because new institutions are costly to create, they require organizations to invest in specialized skills, induce complementary organizational forms and networks that need further coordination and confront individuals with the need to adapt to different political and social identities. These features increase both the attractiveness of the existing institutional arrangement and the costs of switching to another alternative institution (Pierson, 2000).

From a path dependence perspective, major changes are only possible or probable at critical junctures (Verhoest et al, 2010). From time to time, long periods of institutional stability and self-reinforcement are interrupted by a relatively short period of institutional unsteadiness during which a significant change is possible (Mahoney, 2000; Pierson, 2000). Throughout this period of contingency, known as a critical juncture, it is possible to adopt a particular organizational arrangement from among two or more alternatives. The juncture is 'critical' because once a particular option has been chosen, it becomes progressively difficult to return to the initial point during which multiple alternatives were still available (Mahoney, 2000, p. 513; Pierson, 2004, p. 144).

\subsection{Environmental perspective}

According to Verhoest et al (2010), institutional environments are characterized by the development of socially shaped norms to which individual organizations must conform in order to gain legitimacy. Here, public organizational configuration is not a domestic affair, but is rather shaped by external factors that are seen as an appropriate model of modernity. Therefore, the best way for a new organization to gain and strengthen its legitimacy is to emulate the structure, goals and culture of successful organizations. As this approach highlights, public organizations are compensated for implementing what is considered acceptable structures and processes, and not for the quantity and quality of their outputs (Christensen and Lægreid, 2007; Verhoest et al, 2010; Laegreid and Verhoest, 2010). 
The process by which a public organization copies another's strategy, structure and culture results in organizational isomorphism (DiMaggio and Powell, 1983). "As with the cultural-institutional perspective, the choice of organizational structure is primarily based on logic of appropriateness, but in this case the dominant norms and values in the environment are most important" (Verhoest et al, 2010, p. 38). DiMaggio and Powel (1983) identify three processes that explain why organizations become more alike: coercive, mimetic and normative isomorphism.

\section{Coercive isomorphism}

Isomorphism is coercive when a public organization adopts goals, structures, norms and values, because it is pressured via laws or regulations, other organizations or powerful actor. Proponents of external pressure mechanisms emphasize that the external actors use their great leverage, especially over developing countries, through instruments such as loan conditionality (Haggard, 1990; Pollitt, 2004; Weyland, 2007). As Pollitt stresses, "the importer may not be in the position of a freely-choosing consumer of the reform in question. The reform may, for example, be a conditionality of aid. Or it may be what is strongly advised by a big, rich country to a small, poor, underdeveloped country - advice which may be hard to refuse" (Pollitt et al, 2004, p.4). As a result, national policymakers react to these external pressures, making policy decisions or designing administrative agencies that reflect the international preferences (Haggard, 1990).

\section{Mimetic isomorphism}

Isomorphism is mimetic when public organizations deliberately imitate one another to increase their legitimacy. A new public organization is particularly likely to copy the structure and process of a successful and prestigious public agency, within their organizational field, when the environment is highly uncertain and thus needs to search for an arrangement and strategy that will increase its possibility of survival (Jones, 2012; Verhoest et al, 2010). According to this perspective, a successful public organization becomes a uniform agency choice across countries, given that it is increasingly perceived as a superior organizational structure due to the salience of its apparent success (Weyland, 2007).

\section{Normative isomorphism}

Isomorphism is normative when public agencies come to resemble one another over time, because they indirectly adopt the norms and values of other public organizations in the environment (Jones, 2010). Following Verhoest et al (2010, p. 38), "normative adoption refers to the kind of dissemination and adoption that arises in organizational field from common norms, values, knowledge and networks held, or engaged in, by various professional groups". 
According to Weyland (2007), the normative isomorphism approach states that powerful international actors influence national policymakers not from the outside, loan conditionality, but rather from the inside, by persuading them concerning what they themselves should want. In this sense, powerful international actors might turn an innovation into a normatively appropriate model of an active symbol of modernity.

\subsection{Task-specific perspective}

The task-specific approach centers on how the particular characteristics of the organization's assignment affect agency design, practice and change. The underlying idea of this approach is that it is not possible to discuss specific organizational structures and processes without taking into account the particular activities to which they apply (Cristensen and Laegreid, 2007). From this view, public organizations are important as long as they help to reduce uncertainty through the establishment of credible commitments between the agency creator and the agency stakeholders, citizens and consumers. The commitment is the expectation that the public agency will carry out the specific policy to solve a particular problem. In other words, the formation of administrative agencies responds to significant events, discontinuities or situations that rendered them necessary as part of the whole public sector system (Kaufman, 1975; Grafton, 1984).

The job that the organization carries out might vary according to the measurability of its outcomes and outputs (Wilson, 1989), the extent of vertical and horizontal specialization (Christensen and Egeberg, 1997; Roness, 2007), its political relevance and attractiveness (Pollitt et al, 2004) and the distinction between regulatory agencies and policy making agencies (Majone, 1997; Gilardi, 2002; Christensen and Lægreid, 2006).

According to Laegreid and Verhoest (2010), the task-specific perspective emphasizes an organization's technical environments, which are mainly determined by the kind of tasks that the agency performs. "These tasks may constrain and enable what an agency and its members are doing, and over time task may be changed as a result of instrumental action or appropriate behavior" (Verhoest et al, 2010). Both the nature of the actual work of the public organization and the specificity of the tasks that the agency performs are important to understand the design of organizations and the way in which they behave and change. 


\subsection{Endogenous and gradual organizational change}

Each of the four theoretical perspectives presented suggests a theory of organizational change. For the structural-instrumental perspective, organizations are expected to evolve as an answer to shifts in the balance of power or the goals of powerful actors. For the cultural-institutional approach, a change is likely when long periods of institutional stability and self-reinforcement are interrupted by a relatively short period of institutional unsteadiness. For the task-specific perspective, organizations might possibly change in response to changes in the basic functions around which the agency is organized. From an environmentalinstitutional perspective, a change in the cultural script that defines what constitutes a legitimate or modern organizational form could lead to an agency transformation.

The previous theoretical approaches provide some insights as to what sustains organizations over time as well as understandings on exogenous shifts that may prompt discontinuous organizational changes. However, these approaches do not provide a long-term explanation for organizational change that captures the influence of, not only, external shocks but also endogenous sources of transformation. In this regard, Thelen (2010) proposes an alternative approach of endogenous and gradual ways of understanding institutional change. Thelen calls attention to forms of institutional change that are linked to issues of compliance and enforcement. Here, organizations are conceived as a set of rules that are enforced or complied with by actors of various sorts. The analysis brings into consideration the fact that rules are never simply applied; rather, they are always interpreted, enforced and enacted by actors with divergent and conflicting interests (Streeck and Thelen, 2005; Thelen and Mahoney, 2010).

The need to enforce institutions carries its own dynamics of potential change, emanating not just from the politically contested nature of institutional rules but also, importantly, from a degree of openness in the interpretation and implementation of these rules. Even when institutions are formally codified, their guiding expectations often remain ambiguous and always are subject to interpretation, debate and contestation. ${ }^{6}$

This characteristic of institutions is important because it opens up space for analyzing what Paul Pierson (2004) has called the 'gaps'. Gaps are related to the discrepancies between the purposes for which an institution was designed and its

\footnotetext{
${ }^{6}$ Mahoney, James and Kathleen Thelen (2010) "A Theory of Gradual Institutional Change". In: Explaining Institutional Change. Ambiguity, Agency, and Power. Cambridge: Cambridge University Press, P 10
} 
actual on-the-ground implementation and effects. According to Thelen (2009), there are four sources of gaps, with the first relating to the cognitive limits of the institutional designers. Institutions can come to function under a somewhat different coalition from the initial one, thus adapting it to their own, very different, ends. Second, gaps materialize because institution-building is a matter of political concession, which implies that institutions and rules are often vague from the beginning. Third, institutions are not neutral; rather, given that institutions instantiate power, they are contested. "However, since the 'losers' in these contests do not always go away, it sometimes happens that actors who are not part of the 'design coalition' may nonetheless find ways to occupy and redeploy institutions not of their own making" (Thelen, 2006, p. 491). The fourth source of gap is time, given that institutions almost always live longer than their designers.

In short, organizational change is animated by the two logics of action described by Verhoest et al (2010). However, incremental and endogenous change emerges from the gaps between the organization and its interpretation and the organization and its enforcement. Moreover, differences in levels of discretion in the interpretation or enforcement of organizations also help to explain modes of organizational change.

Streeck and Thelen (2005) and Mahoney and Thelen (2010) identify four modes of gradual and transformative institutional change: displacement, layering, drift and conversion. Mahoney and Thelen define each dimension of gradual change by asking the questions in Table 1 about the existing institutional arrangement:

Table 1

Types of gradual change

\begin{tabular}{|l|c|c|c|c|}
\hline & Displacement & Layering & Drift & Conversion \\
\hline $\begin{array}{l}\text { 1. Are old rules } \\
\text { removed? }\end{array}$ & Yes & No & No & No \\
\hline $\begin{array}{l}\text { 2. Are old rules } \\
\text { neglected? }\end{array}$ & - & No & Yes & No \\
\hline $\begin{array}{l}\text { 3. Is the } \\
\text { impact/enactment } \\
\text { of old rules } \\
\text { changed? }\end{array}$ & - & No & Yes & Yes \\
\hline $\begin{array}{l}\text { 4. Are new rules } \\
\text { introduced? }\end{array}$ & Yes & Yes & No & No \\
\hline
\end{tabular}

Source: Mahoney and Thelen (2010) 
Displacement: this occurs when the traditional institutional arrangements are discredited or pushed aside in favor of new institutions and associated behavioral logics (Streeck and Thelen, 2005). This mode of institutional change could be abrupt, as in the case of revolutions, or smooth.

Layering: this mode of institutional change implies additions, amendments or revisions to existing institutions. Layering occurs when new rules are introduced on top of or alongside existing ones. Layering can bring considerable transformative potential in the longer run if the adjustments to the old institutions alter their logic, setting in motion dynamics through which these amendments actively crowd out or supplant by default the old institutional arrangement over time (Streeck and Thelen, 2005).

Drift: this occurs when changes in the political and economic environment in which the institutional arrangement is embedded force changes in the impact of existing rules which formally do not change.

Conversion: takes place when existing institutions are strategically redirected to new goals, functions or purposes. Here, the rules remain formally the same yet are interpreted and enacted in new ways (Thelen, 2003, 2005, 2010). Such redeployment might occur as a consequence of new environmental challenges, to which policymakers respond by directing existing institutional resources to new ends. Alternatively, "it can come about through changes in power relations, such that actors who were not involved in the original design of an institution and whose participation in it may not have been reckoned with take it over and turn it to new ends" (Streeck and Thelen 2005, p. 38).

Mahoney and Thelen (2010) offer a general framework to understand the conditions under which one mode of institutional change is more likely to emerge than another. The framework poses as key explanatory factors the character of existing institutional rules and the prevailing political context. The characteristics of the political context are understood by Mahoney and Thelen as the number of individual or collective actors that have to agree to change the status quo. Tsebelis (2002) calls these actors veto players, stating that they might have the capacity to veto both changes in the rules themselves, as well as changes in the rule's enactment in practice. If agents of change face political contexts with numerous veto possibilities, it will be difficult for them to replace the existing institutional rules for new ones. On the other hand, the character of existing institutional rules refers to the differences in levels of discretion in the interpretation or enforcement of formal rules. 
Here, the forms of institutional change described are linked to the two explanatory factors by asking two broad questions: (i) does the political context afford defenders of the status quo strong or weak veto possibilities? Moreover, (ii) does the targeted institution afford actors opportunities for exerting discretion in its implementation and enforcement? (Thelen, 2009, p. 489; Mahoney and Thelen, 2010, p. 18). The answer to these inquiries is detailed in Table 2.

Table 2

Political Context and modes of institutional change

\begin{tabular}{|c|c|c|c|}
\cline { 3 - 4 } \multicolumn{2}{c|}{} & \multicolumn{2}{|c|}{$\begin{array}{r}\text { Characteristics of the targeted } \\
\text { institution }\end{array}$} \\
\cline { 3 - 4 } \multicolumn{2}{c|}{} & $\begin{array}{c}\text { Low level of } \\
\text { discretion }\end{array}$ & $\begin{array}{c}\text { High level of } \\
\text { discretion }\end{array}$ \\
\hline $\begin{array}{c}\text { Characteristics of } \\
\text { the political } \\
\text { context }\end{array}$ & $\begin{array}{c}\text { Strong veto } \\
\text { possibilities }\end{array}$ & Layering & Drift \\
\cline { 2 - 4 } & $\begin{array}{c}\text { Weak veto } \\
\text { possibilities }\end{array}$ & Displacement & Conversion \\
\hline
\end{tabular}

Source: Mahoney and Thelen (2010)

As Table 2 suggests, displacement is improbable in the context of strong veto possibilities. Similarly, attempts at active conversion will be difficult in such a context, given that veto powers also apply to the realm of rule enactment. Instead, drift and layering are more plausible as strategies of change in political environments with strong veto players.

On the other hand, institutional change via layering or displacement is less likely where actors enjoy great discretion in the interpretation or enforcement of the rules. On the contrary, the outcomes of conversion and drift are less probable where agents of change face an institution in which there is very little room for discretion in interpretation and enforcement. Conversion normally occurs when rules are ambiguous enough to permit different interpretations. Drift can occur when a gap opens up between rules and enforcement. By contrast, layering and displacement do not rely on exploiting ambiguities in the rules themselves (Mahoney and Thelen, 2010).

Mahoney and Thelen's model also identifies four dominant agents that are behind the types of change explained. These actors may or may not have transformational motives, which means that "institutional change can be an unintended by-product that grows out of distributional struggles in which no party explicitly sought the changes that eventually occurred" (Mahoney and Thelen 2010, p. 22-23). These actors are defined by asking the questions depicted in Table 3 . 
Table 3

Types of change agents

\begin{tabular}{|l|c|c|}
\hline & $\begin{array}{l}\text { Does the actor seek to } \\
\text { preserve the existing } \\
\text { institutional rules? }\end{array}$ & $\begin{array}{l}\text { Does the actor follow } \\
\text { rules of institution? }\end{array}$ \\
\hline Insurrectionaries & No & No \\
\hline Symbionts & Yes & No \\
\hline Subversives & No & Yes \\
\hline Opportunists & Yes/No & Yeso \\
\hline
\end{tabular}

Source: Mahoney and Thelen 2010

Subversives: are agents of change who work within the structure of rules, waiting for chances to overturn them. These agents probably emerge in the context of strong veto possibilities and few rule interpretation. Subversives are often associated with layering, adding new institutions and rules alongside existing ones.

Symbionts: are actors who rely on and seek to preserve institutions not of their own making. These agents are more likely to flourish in environments characterized by strong veto possibilities and high enforcement discretion. Symbionts are often associated with institutional drift.

Insurrectionaries: are agents of change who consciously and actively mobilize against the status quo. These actors are more likely to thrive in environments characterized by low discretion and weak veto possibilities. Insurrectionaries promote the displacement of old institutions with new ones.

Opportunists: are actors with ambiguous preferences about institutional continuity (they do not actively seek to preserve or change institutions). Opportunists take advantage of opportunities within the prevailing rules to achieve their objectives without trying to change the rules or underlying institutions. These actors tend to flourish in settings where there is a great deal of discretion in how institutions are enacted and there are few veto players to prevent changes in the status quo. Opportunists are often associated with institutional conversion.

\subsection{Conclusion}

This Chapter has presented five theoretical branches that offer plausible reasons to explain the creation, evolution and change of public organizations. The first four, point to exogenous factors as an engine of change, overlooking shifts based on endogenous developments that come along incrementally. The fifth approach 
offered by Thelen stresses that organizational change might result from an accumulation of gradual and incremental transformations. Rather than emanating from the outside, change can be endogenous and in some cases produced by the very behavior that an institution itself generates.

Departing from these competing theories that conceptualize modes of organizational change, next Chapter presents the causal mechanisms for each theoretical approach by means of which it is plausible to encounter a given organizational change. Also Chapter 4, proposes process tracing as a suitable tool for theory-testing and explains the methodology to assessing the operation of the alternative causal mechanisms. 


\section{Chapter 4: Process tracing and causal mechanisms}

This research relies on techniques that fall under the label of process tracing in order to use evidence, from within and between case studies, which allows assessing the hypothesized causal mechanisms that explain change in the Latin American central planning agencies. As Benett and Checkel (forthcoming, p. 7) stress, "process tracing examines the deductive observable implications of hypothesized causal mechanism within a case to test whether these might in fact explain the case, or it inductively uses evidence from within a case to develop hypothesis that might explain the case". In sum, process tracing investigates the working of the mechanism that contributes to produce an outcome (Beach and Pedersen, 2013).

Causal mechanism is defined here as a route in which a causal variable of interest influences an outcome. ${ }^{7}$ According to Beach and Pedersen (2013), that route linking cause and outcome can be understood using a machine analogy. "Each part of the theoretical mechanism can be thought of as a toothed wheel that transmits the dynamic causal energy of the causal mechanism to the next toothed wheel, ultimately contributing to producing outcome Y" (Beach and Pedersen, 2013: p. 29). The identification of causal mechanisms occurs when one puts together general or theoretical knowledge of the world with empirical knowledge of how $\mathrm{X}$ and $\mathrm{Y}$ interrelate by means of examining the intermediate factors and motivations between the explanatory and outcome variables (Gerring, 2004). Beach and Pedersen (2013) suggest a general model expressed as:

\section{$X \rightarrow\left[\left(n_{1} \rightarrow\right) *\left(n_{2} \rightarrow\right)\right] Y$}

Where $X$ is the explanatory variable transmitting its causal forces to producing outcome $\mathrm{Y}$, through a causal mechanism composed of two parts $\mathrm{n} 1$ and $\mathrm{n} 2$ (each part composed of entities and activities that together produce change). The arrow symbolized the transmission forces and the ${ }^{*}$ stands for and. In this context,

\footnotetext{
${ }^{7}$ Benett and Checkel define causal mechanism as "ultimately unobservable physical, social, or psychological processes through which agents with causal capacities operate, but only in specific contexts or conditions, to transfer energy, information, or matter to other entities. In doing so, the causal agent changes the affected entities' characteristics, capacities, or propensities in ways that persist until subsequent causal mechanisms act upon them. If we are able to measure changes in the entity being acted upon after the intervention of the causal mechanism and in temporal or spatial isolation from other mechanisms, then the causal mechanism may be said to have generated the observed change in the entity" (forthcoming, p 15).
} 
Glasser and Strauss (1967) and Gerring (2007) indicate that these mechanisms are often discovered in vivo, gaining insight into the intentions, reasoning capabilities and information-processing procedures of the actors involved in a given setting. Valuable insights might be obtained from verbal accounts describing and interpreting the decisions and development in organizations.

The Chapter proceeds as follows. First, the underlying causal mechanisms that can be implicitly drawn from theory to cause organizational change are introduced, as well as the specific observable implications of each mechanism that the research's fieldwork seeks empirical evidence of. Next, the Chapter presents the research's approach to data collection, management and analysis to then address the methodological considerations of case selection.

\subsection{Causal mechanisms in action}

As stated, the underlying research in this document seeks analyzing the major institutional variables that have influenced the changing role of Latin American central planning agencies during the last sixty years. Accordingly, the center of attention on causal mechanisms means that "positive cases" in which changes in the planning organization have been set in motion are of particular interest, allowing the in-depth examination of the operation of transformation.

Beach and Pedersen (2013) suggest a three step-process for explaining outcome through process tracing. The first step is to hypothesize a causal mechanism between $\mathrm{x}$ and $\mathrm{y}$ based on existing theories. The second step is operationalizing the causal mechanism by translating theoretical expectations into specific observable manifestations. In other words, deducing what evidence should be in place in order to validate theory. And third, the collection of empirical evidence to see if the causal mechanism is present, if it operates as predicted, and whether it is sufficient.

As shown in Chapter 3, the explanation of public organizations' creation, evolution and change can be approached from four different explanatory clusters focusing on external factors, as well as a fifth alternative that considers endogenous sources of organizational change. For each of these approaches, the research first identifies a distinct theoretical logic of action or causal mechanism for interpreting organizational change. In turn, based on the research's own inductive analysis it suggests the set of observable manifestations that ought to be in place, and finally presents the method for data collection to find whether there is empirical evidence to show that all elements of the causal mechanism were present.

First, for the structural-instrumental perspective, this research derives and presents in Table 4 the causal mechanism at play for explaining organizational change. A 
given interplay of political forces (" $x$ ") transmits its causal forces to produce an organizational change (" $y$ ") through two parts: i) the existence of an enacting coalition $\left(\mathrm{n}_{1}\right)$ who see the agency as an instrumental purpose and to this end builds the coalition, drafts and passes the law and decides on a form of delegation; and ii) the setting of administrative procedures and organizational structure to elevate transaction costs $\left(\mathrm{n}_{2}\right)$ to prevent future organizational drift.

Table 4

Causal mechanism for the structural-instrumental perspective

\begin{tabular}{|c|c|c|c|}
\hline $\begin{array}{l}\text { Explanatory } \\
\text { variable }\end{array}$ & \multicolumn{2}{|c|}{$\begin{array}{l}\text { Causal mechanism } \\
{\left[\left(\mathbf{n}_{1} \rightarrow\right)^{*}\left(\mathbf{n}_{2} \rightarrow\right)\right]}\end{array}$} & $\begin{array}{c}\text { Dependent } \\
\text { variable }\end{array}$ \\
\hline $\begin{array}{l}\text { Interplay of } \\
\text { political } \\
\text { forces } \\
\text { (x) }\end{array}$ & $\begin{array}{l}\quad \text { Enacting Coalition (n1) } \\
\text { Entities involved: } \\
\text { - Congress } \\
\text { - President } \\
\text { - Interest groups } \\
\text { Activities: } \\
\text { - Coalition building } \\
\text { - Drafting/passing legislation } \\
\text { - Delegation of policy making }\end{array}$ & $\begin{array}{l}\text { Transaction costs }\left(\mathbf{n}_{2}\right) \\
\text { Activities: } \\
\text {-Adm. procedures } \\
\text { - Org. structure }\end{array}$ & $\begin{array}{l}\text { Organizational } \\
\text { change }(y)\end{array}$ \\
\hline
\end{tabular}

Source: Luis B Mejía, 2014

In terms of the specific observable implications field work seeks to find evidence of enacting coalitions to create the central planning agency, promoted by either the Congress and interest groups, or by the President, that have private economic interests in the agency and whom from the out start strategically manipulate administrative design attributes of the planning organization to control the agency and prevent others from taking over/changing it. Besides the coalition itself, evidence for this causal mechanism looks into explicit legal restrictions set forth to make costly any attempt at changing the organization: constitutional reform to abolish/change the agency; multiple debates in Congress to abolish/change the agency; rigid bylaws and mandates of the agency; restrictions in the allocation of the agency's budget; restrictions for the free appointment and removal of the agency's director, etc.

Second, for the cultural-institutional perspective a three-part causal mechanism linking organizational culture $(\mathrm{x})$ to organizational change $(\mathrm{y})$ is inferred and presented in Table 5: i) the initial choice of organization $\left(\mathrm{n}_{1}\right)$ is seen as advantageous imprinting the agency with a long term cultural mark; ii) short periods of institutional instability coming from political and/or economic crises ( $\left.\mathrm{n}_{2}\right)$ 
open the door for organizational change; and iii) a new process of socialization and self-reinforcing $\left(\mathrm{n}_{3}\right)$ of the organizational cultural values is set in place.

Table 5

Causal mechanism for the cultural-institutional perspective

\begin{tabular}{|c|c|c|c|c|}
\hline $\begin{array}{l}\text { Explanatory } \\
\text { variable }\end{array}$ & \multicolumn{3}{|c|}{$\begin{array}{l}\text { Causal mechanism } \\
{\left[\left(n_{1} \rightarrow\right)^{*}\left(n_{2} \rightarrow\right)^{*}\left(n_{3}\right)\right]}\end{array}$} & $\begin{array}{c}\text { Dependent } \\
\text { variable }\end{array}$ \\
\hline $\begin{array}{l}\text { Org. Culture } \\
(x)\end{array}$ & $\begin{array}{l}\text { Initial environmental } \\
\text { conditions }\left(\mathbf{n}_{\mathbf{1}}\right)\end{array}$ & $\begin{array}{l}\text { Critical } \\
\text { juncture (n2) } \\
\text { Activities: } \\
\text { - Institutional } \\
\text { instability } \\
\text { - Economic and } \\
\text { political crises }\end{array}$ & $\begin{array}{l}\begin{array}{l}\text { Adoption } \\
\text { new values }\end{array} \\
\qquad\left(\mathbf{n}_{3}\right) \\
\text { Activities: } \\
\text { - Institutional } \\
\text { cultural shift, } \\
\text { socialization } \\
\text { and } \\
\text { reproduction }\end{array}$ & $\begin{array}{c}\text { Org. } \\
\text { change } \\
\text { (y) }\end{array}$ \\
\hline
\end{tabular}

Source: Luis B Mejía, 2014

The observable manifestations that are traced in the fieldwork to assess the strength of this causal mechanism, focus primarily on explicit mechanisms of socialization and reinforcement of the agency's culture and whether or not at episodes of critical junctures, like coups d'état and economic crises there is empirical evidence that the planning agency shifted into a different trajectory.

Third, Table 6 exhibits the implicit causal mechanism of the environmental perspective connecting organizational isomorphism $(x)$ to an organizational change (y). In this case, the causal mechanism is only composed of one part, organizational mirroring $\left(\mathrm{n}_{1}\right)$ whereby organizational transformations are transmitted by means of mandatory requirements from powerful actors; the direct and willingly imitation of organizational structures that are apparently successful elsewhere; and the influence of international advisors whom through their knowledge and experience encourage countries to adopt the organizations promoted by IFIs.

In this case, practical evidence of organizational isomorphism to support the causal mechanism of the environmental perspective includes: conditionality loans; foreign missions that replicate external successful experiences in the host-country; training the agency's staff and officials in specific schools of thought; technical international cooperation. In summary evidence is found to support that transformations in the central planning agency are a function of the influence of international actors, 
particularly the World Bank, ECLA and USA, over domestic policymakers, using coercion, persuasion or diffusion means.

Table 6

Causal mechanism for the environmental perspective

\begin{tabular}{|c|c|c|}
\hline $\begin{array}{c}\text { Explanatory } \\
\text { variable } \\
\text { " } x "\end{array}$ & $\begin{array}{c}\text { Causal mechanism } \\
\qquad\left(\mathrm{n}_{1} \rightarrow\right)\end{array}$ & $\begin{array}{c}\text { Dependent variable } \\
\text { "y" }\end{array}$ \\
\hline $\begin{array}{c}\text { Organizational } \\
\text { Isomorphism } \\
\text { (x) }\end{array}$ & $\begin{array}{l}\quad \text { Organizational mirroring }\left(\mathbf{n}_{\mathbf{1}}\right) \\
\text { Entities involved: } \\
\text { - IFIs } \\
\text { - International Cooperation Agencies } \\
\text { - International advisors } \\
\text { Activities: } \\
\text { - Imposition of new organizational forms } \\
\text {-Persuasion } \\
\text { - Willingly adoption of successful } \\
\text { organizational models } \\
\text { - Diffusion of economic/political recipes }\end{array}$ & $\begin{array}{c}\text { Organizational change } \\
(y)\end{array}$ \\
\hline
\end{tabular}

Source: Luis B Mejía, 2014

Fourth, Table 7 presents the causal mechanism that this research derives for the task-specific theoretical perspective on organizational change. In this case, variations in the prevailing economic model $(x)$ propel the forces for the tailoring/adoption of the organizational functions $\left(\mathrm{n}_{1}\right)$ by the bureaucracy and/or technocracy to respond to the new model thus resulting in the organizational change (y). New functions and structures that are deemed necessary as well as old functions and structures that seem irrelevant or outdated are questioned and eventually created, eliminated and/or transformed, deriving into a possible organizational change.

Empirical evidence to support this causal mechanism starts by identifying historical moments where the prevailing economic model changed, followed by finding the particular economic functions that the new model calls for, and whether those technical functions/needs were actually incorporated/adapted by the agency's bureaucracy and technocracy. 
Table 7

Causal mechanism for the task-specific perspective

\begin{tabular}{|c|c|c|}
\hline $\begin{array}{c}\text { Explanatory } \\
\text { variable } \\
\text { " } x "\end{array}$ & $\begin{array}{l}\text { Causal mechanism } \\
\qquad\left(\mathrm{n}_{1} \rightarrow\right)\end{array}$ & $\begin{array}{c}\text { Dependent variable } \\
\text { " } y \text { " }\end{array}$ \\
\hline $\begin{array}{l}\text { Prevailing } \\
\text { economic } \\
\text { model (x) }\end{array}$ & $\begin{array}{l}\text { Tailoring organizational functions (n) } \\
\text { Entities involved: } \\
\text { - Bureaucracy } \\
\text { - Technocracy } \\
\text { Activities: } \\
\text { - Reassignment of tasks } \\
\text { - Adoption/elimination of tasks }\end{array}$ & $\begin{array}{c}\text { Organizational change } \\
(\mathrm{y})\end{array}$ \\
\hline
\end{tabular}

Source: Luis B Mejía, 2014

Fifth, Table 8 presents the causal mechanism that based on Thelen affords institutions to experience gradual modes of institutional change. In this case there are two explanatory variables at play. First, the characteristics of the political context $\left(\mathrm{x}_{1}\right)$ in which theory supposes that there are ongoing political struggles $\left(\mathrm{n}_{1}\right)$ over the existing institutional arrangements and the existence of veto points ( $\left.\mathrm{n}_{2}\right)$ as well as actors capable of slipping in to alter the status quo. Second, the characteristics of the targeted institution ( $\left.\mathrm{x}_{2}\right)$ referred to the ambiguity of institutional rules $\left(n_{3}\right)$ that allow interested actors to reinterpret discretionally and to their favor those rules, and in this way alter the institutional arrangement. Differences in veto possibilities and the extent of discretion in institutional enforcement allow actors pursuing change to adopt a different strategy $\left(\mathrm{n}^{4}\right)$ of gradual transformation.

For this approach, field work seeks evidence of the following aspects: (i) is there a political struggle over the planning agency; (ii) which actors have interests over changing the agency and which specific veto points they face; (iii) extent of ambiguity in the planning agency's mission and functions; and (iv) extent of enforcement of the agency's rules. 
Table 8

Causal mechanism for the endogenous-incremental perspective

\begin{tabular}{|c|c|c|c|c|}
\hline $\begin{array}{l}\text { Explanatory } \\
\text { variable }\end{array}$ & \multicolumn{3}{|c|}{$\begin{array}{c}\text { Causal mechanism } \\
{\left[\left(n_{1} \rightarrow\right)^{*}\left(n_{2} \rightarrow\right)^{*}\left(n_{3} \rightarrow\right)^{*}\left(n_{4} \rightarrow\right)\right]}\end{array}$} & $\begin{array}{l}\text { Dependent } \\
\text { variable }\end{array}$ \\
\hline $\begin{array}{l}\text { Charac. of } \\
\text { the political } \\
\text { context }\left(x_{1}\right)\end{array}$ & $\begin{array}{l}\text { Ongoing political } \\
\text { struggles (n1) } \\
\text { Entities involved: } \\
\text { - Congress } \\
\text { - President } \\
\text { - Bureaucracy } \\
\text { Activities: } \\
\text { - Interest in the } \\
\text { institution }\end{array}$ & $\begin{array}{l}\text { Veto points (n2) } \\
\text { Entities involved: } \\
\text { - Congress } \\
\text { - President } \\
\text { - Bureaucracy } \\
\text { Activities: } \\
\text { - Means to } \\
\text { confront veto } \\
\text { points and alter } \\
\text { status-quo }\end{array}$ & \multirow{2}{*}{$\begin{array}{l}\begin{array}{r}\text { Strategy of } \\
\text { change (n4) }\end{array} \\
\text { Entities } \\
\text { involved: } \\
\text { - Congress } \\
\text { - President } \\
\text { - Bureaucracy } \\
\text { Activities: } \\
\text { - Adapting a } \\
\text { strategy of } \\
\text { change }\end{array}$} & \multirow[t]{2}{*}{$\begin{array}{c}\text { Org. } \\
\text { change }(y)\end{array}$} \\
\hline $\begin{array}{l}\text { Charac. of } \\
\text { the targeted } \\
\text { institution } \\
\left(\mathrm{x}_{2}\right)\end{array}$ & $\begin{array}{r}\text { Entities } \\
- \text { Cor } \\
\text { - Pre } \\
\text { - Bure } \\
\text { Acti } \\
\text { - Extent of int } \\
\text { enforcem }\end{array}$ & $\begin{array}{l}\text { ity }\left(\mathbf{n}_{3}\right) \\
\text { ivolved: } \\
\text { ress } \\
\text { dent } \\
\text { icracy } \\
\text { ties: } \\
\text { pretation and } \\
\text { tt of rules }\end{array}$ & & \\
\hline
\end{tabular}

Source: Luis B Mejía, 2014

The research considers the explanatory power of each causal mechanism, represented by a specific actor or group of actors, in the case studies of Argentina, Chile, Colombia and Ecuador. Using these different expectations as the baseline, in each of the analyzed countries the research empirically traces whether all parts in a given causal mechanism were present, and were sufficient to explain the decision making process leading to a change in the planning organization

The starting point of the research for investigating the evidence on alternative explanations (process tracing) is the creation of the central planning agency in each of the public administrative structures of the selected countries. Even though this historical moment occurred at the end of the 1950s in almost all Latin American countries, the research reviews the years prior to this event in order to take into 
account historical incidents that might have had powerful effects in the creation of such organizations. Subsequently, the research traces the transformations that the organization has experienced until today. In this regard, Falleti (2006) states that the historical narratives are useful for contextualizing the different steps of the process rather than leaving them fragmented into analytical stages.

\subsection{Data collection methods}

The empirical evidence or data used to assess the power of the five alternative explanations of organizational change in the Latin American central planning agencies is based on elite interviewing. Throughout the fieldwork phase of this dissertation, around forty semi-structured interviews were conducted with former directors and ministers of domestic planning organization, former directors of ECLA and ILPES and former congressman. Moreover, domestic policymakers and officials from international financial institutions were also interviewed. These interviewees were purposefully ${ }^{8}$ selected with the aim of drawing a sample that includes the most important political players who participated in the events being studied. By interviewing key participants in the process of organizational change, this research gained data, from first-hand testimony, about the political debates and deliberations that preceded decision making and action taking concerning agency transformation. It is important to highlight that many of the people interviewed occupied different public posts during different governments, as well as various positions within the planning organization across time. Similarly, some of these people played positions in international organizations after working on the planning agency. For instance, Jose Luis Machinea served as a high-ranking staff of the Argentinean planning agency under President Alfonsin during the early-1980s, before serving in the Ministry of Economy under President de la Rúa during the late-1990s. Finally, Machinea served as the ninth Executive Secretary of the United Nations Economic Commission for Latin America and the Caribbean (ECLA) from December 2003 to May 2008.

All the interviews were based on the same open-ended interview protocol. The instrument was organized around five categories: (1) the role of interest groups in the creation and change of the central planning agency; (2) the responsibility of critical junctures in the transformation of the planning organization; (3) the role of

\footnotetext{
${ }^{8}$ According to Tansey (2007); "Purposive sampling is a selection method where the study's purpose and the researcher's knowledge of the population guide the process. If the study entails interviewing a pre-defined and visible set of actors, the researcher may be in a position to identify the particular respondents of interest and sample those deemed most appropriate".
} 
the international powerful actors in the diffusion, formation and transformation of the central planning organization; (4) the influence of the changes in the economic development model over the central planning agency; and (5) the role of individual or collective actors whose agreement is necessary to change the status quo, as well as the extent to which an organizational goal or set of goals allows leeway for interpretation. Specific research questions were constructed for each category, adapted to the specific historical circumstances of each case study. In other words, exactly the same categories were kept in the protocol interview of each country, albeit with changes in the specific questions that compose each group. When needed, the main interview questions were complemented with follow-up questions to obtain optimal responses from interviewees. The analysis of the data obtained from the protocol followed the same categories. The interviews took place between June 2010 and June 2012 and were conducted in Spanish ${ }^{9}$. Table 9 shows the interview categories and the type of questions asked in each group.

The data obtained from the elite interviews was confronted, when possible, with information collected from other secondary sources in each country, particularly press articles, policy documents, public speeches, organizational records and legal instruments (i.e Laws and decrees). This triangulation of the information increased the credibility of the findings, cross-checked the causal inference derived from the interviews and revealed the weakness of some sources that might have otherwise been viewed as reliable. The secondary data was coded and compared, following the same categories used to classify the interviews. The secondary information collected is summarized in Appendix 3.

As mentioned above, the process of gathering evidence took place during the fieldwork phase of the dissertation between 2010 and 2012 as follows: Colombia, October 2010-April 2011; Argentina May-June 2011; Chile July-August 2011; and Ecuador, May-June 2012. The data was collected until any one stream of evidence became so repetitive that gathering more of the same kind of evidence was irrelevant and/or the financial and temporal constrains of the research imposed the limit.

\footnotetext{
9 Translations of original quotes from Spanish to English try to respect, in as much as possible, the original sense and lexicon used by the interviewees. Therefore this may result in some grammar inaccuracies in English.
} 
Table 9

Interview categories and type of questions

\begin{tabular}{|c|c|}
\hline Category & Type of question \\
\hline Interest groups & $\begin{array}{l}\text { - What kind of negotiations took place between } \\
\text { the Congress and the executive to obtain } \\
\text { approval of the central planning agency's } \\
\text { creation? } \\
\text { - Which political or social sectors supported the } \\
\text { creation of the central planning agency? } \\
\text { Can you explain the process through which an } \\
\text { administrative agency is created or transformed } \\
\text { in your country? }\end{array}$ \\
\hline Critical junctures & $\begin{array}{l}\text { - In your opinion, did the debt crisis of the } 1980 \mathrm{~s} \\
\text { influence the organizational arrangement of the } \\
\text { planning agency? } \\
\text { - In your opinion, did the interruption of } \\
\text { democratic regimes condition the role of the } \\
\text { planning office? }\end{array}$ \\
\hline $\begin{array}{l}\text { International powerful } \\
\text { actors }\end{array}$ & $\begin{array}{l}\text { - Did the international financial institutions play a } \\
\text { role in the planning agency's creation? } \\
\text { Was the experience of other planning agencies } \\
\text { in the region considered as a model for the } \\
\text { creation or transformation of the planning } \\
\text { agency in your country? }\end{array}$ \\
\hline $\begin{array}{l}\text { Economic development } \\
\text { model }\end{array}$ & $\begin{array}{l}\text { - In your opinion, did the movement from an } \\
\text { economic model based on import substitution } \\
\text { industrialization to an export-oriented economy } \\
\text { have any impact on the structural arrangement } \\
\text { of the central planning agency? }\end{array}$ \\
\hline Gradual change & $\begin{array}{l}\text { - Do the political actors seek to preserve the } \\
\text { existing planning organization? } \\
\text { - Do the political actors follow the rules of the } \\
\text { planning organization? } \\
\text { - How is an administrative agency created or } \\
\text { transformed in your country? } \\
\text { - How are the goals/objectives/tasks of the } \\
\text { administrative agencies assigned in your } \\
\text { country? } \\
\text { What are the existing veto points to create or } \\
\text { transform an agency? }\end{array}$ \\
\hline
\end{tabular}

Source: Luis B Mejía, 2014 


\subsection{Case studies selection criteria}

The research relies on a practice for choosing cases known as maximum variation strategy. This strategy "requires the selection of a set of cases which are intended to represent the full range of values characterizing $X, Y$, or some particular $X \mid Y$ relationship" (Seawright and Gerring, 2008, p300). In concrete, this method involves covering the spectrum of positions in relation to the phenomenon of interest, in this case changes in the central planning agency, in order to gain greater insights by looking at it from all angles. The research compares two groups of countries (Argentina and Ecuador; Chile and Colombia) that historically differ in the trajectories of the changes followed by their planning organization. Indeed, Argentina and Ecuador experienced changes in the central planning agency that resemble a rollercoaster ride. Episodes of rapid change were followed by periods of ostracism, most notoriously during the second half of the 1980s with the full onslaught of the debt crisis and the application of heterodox economic policies. On the other hand, Chile and Colombia present a stark contrast to Argentina and Ecuador's erratic organizational evolution. In fact, the planning organization of these two countries has presented more gradual transformation, with Colombia presenting the most stable organizational trajectory among these four countries.

While the regional range of the research holds constant various context factors, it also encapsulates considerable differences among the countries under investigation.

Argentina and Ecuador have followed a path of political instability for much of the last six decades, with their political systems characterized by the constant alternation of authoritarian and democratic regimes for over half of the $20^{\text {th }}$ century. Argentina had six episodes of military coups, with the longest for a period of seven years, while the military seized the reins of government in Ecuador on two occasions for a total period of 10 years. "Since 1925, Ecuador has experienced more than 35 different administrations, including 13 caretaker governments, 11 administrations originating from a coup, four that were appointed by a constitutional assembly" (Mejía, et al, 2008, p). In the same way, Argentina and Ecuador changed their Constitutions three and eight times during the $20^{\text {th }}$ century, respectively (Nolte, 2011). In contrast, Chile and Colombia experienced a phase of relative institutional steadiness. Chile enjoyed a stable democracy until 1973, when a military regime took control of the country until 1990, before returning to a democratic system that has lasted until present day. Unlike Chile, Colombia is a country virtually free of coups d'état and military dictatorships, with a stable twoparty political system yet also with the longest armed conflict in the region. During 
the $20^{\text {th }}$ century, Chile and Colombia had an average duration of their constitutions of more than 50 years.

These four countries have also diverged in terms of macroeconomic performance. Despite the fact that all four countries have largely been dependent on external revenues from exports of primary products, bananas and later oil in Ecuador, copper in Chile, cereals in Argentina and coffee in Colombia, and thus vulnerable to international price variations and shocks, Chile and to a greater extent Colombia have enjoyed much greater stability in their economies. By contrast, Ecuador and Argentina have confronted frequent and extreme moments of economic recessions and high inflation.

Finally, even though these countries adopted and discharged three distinct national development strategies between 1930 and 2010 (Import Substitution Industrialization, neoliberalism and the restoration of the state's economic presence), each country transitioned between one development strategy to the next and back with different timing and intensity.

\subsection{Conclusion}

In order to examine the causal mechanisms that drive organizational change in the Latin American central planning agencies and assess the explanatory power of different theoretical accounts, this research applies a case study design in combination with the method of process-tracing. In this context, the study is based on in-depth fieldwork in Argentina, Chile, Colombia and Ecuador, tracing the process by which organizational change occurred through personal interviews with leading decision makers, as well as a close review of organizational documents and press. Alternative causal mechanisms of the decision making process are placed upfront in order to contrast them with the empirical data. Part II (Chapters 6 to 9) is dedicated to case studies, with each Chapter tracing the creation, evolution and change of the planning organization in the country over the last sixty years. 


\section{Part II. Historical Narratives: Four Case Studies}




\section{Chapter 5: Argentina case study}

\subsection{The genesis and evolution of the planning agency}

Argentina has a long planning tradition that can be traced back to the end of the 1920s. As a result of the 1929 stock market collapse and the subsequent international economic crises, Argentina was forced to change its model of outward growth ${ }^{10}$ in one founded in greater state regulation of the economy and the establishment of an inward-oriented growth pattern. The new model was based on promoting industrialization to enhance the domestic market and reduce imports. At this early stage, Import Substitution Industrialization was adopted into Argentina's economic policy, replacing agricultural exports production as the dynamic core of the Argentine capitalism (Smith, 1989).

After 1930, the Argentinean public sector was reorganized in order to adapt itself to the new economic model. The strategy focused on the expansion of state intervention in the economy through the creation of a Central Bank in 1935, as well as the establishment of regulatory boards for marketing agricultural products; for instance, the National Board of Grains and the National Board of Meat were created during the mid-1930s (Smith, 1989). Additionally, new policy instruments such as foreign exchange controls, industrial credit schemes and income taxes were put in place by the government. As a result, the profit rates of the importsubstitution sectors increased to the detriment of rural producers, bringing about a structural transformation of the economy and a new economic class, the industrial entrepreneurs.

Juan Domingo Peron (1946-1952) assumed presidential office in 1946. The Peronist regime faced economic problems related to the exhaustion of the import substitution model. To avoid stagnation, Argentina's government pursued a successful ${ }^{11}$ strategy of widening the internal market and redistributing income through policies of industrial reconversion. This period was also characterized by direct public intervention through subsidies and state ownership of certain key industries. Moreover, Peron launched a wide nationalization program that expanded to the banking system, railways and public service enterprises, as well as an internal market development strategy and industrialization program. Peron created the Technical Secretariat of the Nation's Presidency (Secretaria Técnica de la Presidencia de la Nación) as the governance body of his reforms, which was in

\footnotetext{
${ }^{10}$ During the 1920s, Argentina's exports counted for almost 30 percent of gross domestic production. The sharp drop in its volume of export and the worsening of its terms of trade with the industrial economies were a potential disaster.

${ }^{11}$ Gross domestic product increased from 25 to 29 percent between 1943 and 1948.
} 
charge of coordinating both administrative reforms and national development planning.

In October 1946, the government presented the first five-year development plan (1947-1951) to Congress. This plan consisted of 27 law projects grouped in three main sections: (i) state governance dealing with public administration issues; (ii) national defense associated with both internal and external security policies; and (iii) an economic plan centered on economic and social policies. The plan included different ways and mechanisms for financing the proposed policies.

To coordinate the implementation of the five-year plan, the government issued organic law $\mathrm{N}^{\circ} 13.532$ of 1949 in which the Ministry of Technical Affairs (Ministerio de Asuntos Técnicos) was created. Inside this Ministry, the National Planning Division assumed responsibility over all planning tasks related to the first five-year plan. Additionally, in 1951, the government created the National Planning Council as an organism in charge of defining the government's economic orientation.

On November 11, 1951, Juan Domingo Peron was re-elected for the 1952-1958 period. During this time, Peron primarily stressed supporting foreign capital investment and promoting agricultural development. The Ministry of Technical Affairs initiated the second five-year plan, which was issued by Congress through law 14.184 of 1952 . This second five-year plan consisted of five main chapters: (i) social action; (ii) economic action; (iii) finance and commerce; (iv) public works and services; and (v) military plans.

In July 1954, the government abolished the Ministry of Technical Affairs, replacing it with a Secretariat of Technical Affairs reporting directly to the President of the Nation. However, implementation of the second five-year plan was interrupted in September 1955 due to a coup d'etat. The military government (1955-1958), which named itself the "freedom revolution" (la revolución libertadora), closed Congress, exiled Peron and outlawed Peronism as a political movement.

The military government soon dismantled the planning system created by Peron and replaced the second five-year plan with the so-called Prebisch Plan ${ }^{12}$ as its framework for economic policy. The Prebish plan mainly focused on containing

\footnotetext{
12 The military government asked Raul Prebisch to advise government in the design of a governmental economic plan. Raul Prebish was an Argentine economist president of the Argentinean Central Bank during the great depression; secretary general of ECLA from 1949 to 1960; secretary-general of the United Nations Conference on Trade and Development from 1964 to 1969. Prebish is also known for his contribution to structuralist economics, in particular the Singer-Prebisch thesis.
} 
inflation by reducing the fiscal deficit, reducing state intervention in the economy and proposed the country's inclusion in the International Monetary Fund and World Bank. Due to policies that removed state control over foreign exchange, prices and wages, the presence of transnational corporations and financial institutions in Argentina substantially increased during this period. According to Smith (1989), the result of this new economic transformation was the realignment and diversification of the Argentinean class structure. For example, besides the traditional export-oriented land tenants, merchants, industrialists and an urban middle class also started to emerge.

\subsection{The National Development Council-CONADE}

In 1958, democracy returned to Argentina, with Arturo Frondizi (1958-1962) from the Radical party winning the presidential election. Frondizi found himself supported by a fragile electoral alliance comprising Peronists, on the one hand, and the military, industrial, financial and rural sectors on the other (Wynia, 1978).

His term in office was marked by taking developmentalism as a basic policy of government. Assisted by a left-oriented advisor, Rogelio Frigerio ${ }^{13}$, in the economic policy making and guided by ECLA's critique of export dependence, Frondizi prepared a development program focused on industrializing the country through the use of foreign capital (Wynia, 1978). Frondizi's program mainly consisted of: (1) launching an industrialization program for raw materials and full exploitation of the nation's natural resources; (2) rejecting the concept of the international division of labor; (3) rapid mechanization of the agro industry; (4) attracting foreign capital, especially through international financial organizations; and (5) implementing a rigorous stabilization plan under IMF auspices. This program sought to promote a new stage of industrialization, now under the hegemony of transnational groups. According to Mallon and Sourrouille (1975), Frondizi's developmentalist strategy embraced a clever combination of ideas designed to appeal to both liberal and national populist interest groups: entrepreneurs did not need to fear foreign competition, agricultural property rights would not be tampered with and the military could maintain control over the domestic production of strategic materials (Mallon and Sourrouille, 1975).

However, this multiparty coalition promptly collapsed. Peronists considered industrialization through foreign capital as a disguised form of economic capitalism; organized labor was reluctant to implement the IMF proposals,

\footnotetext{
${ }_{13}$ Argentinean marxist economist and politician highly visible for his ideas of accelerating economic growth and reaching social progress through developing national industry and building a national identity.
} 
especially those related with wages; and the military feared that the alliance between Frondizi and the Peronists would result in the government abandoning the IMF stabilization program. According to Sikkink (1993), the tremendous fragility of Frondizi's government was exposed by his inability to maintain his closest allies in policy making positions. In this sense, the President's narrow base of political support contributed to his vulnerability to the demands of the Argentinean military for policy or cabinet changes (Wynia, 1978). For instance, the military forced Frondizi to dismiss Rogelio Frigerio and his economic team, replacing him with Alvaro Alsogaray ${ }^{14}$ and his own economic staff. In early 1959, the Argentinean President appointed Alsogaray as Minister of Economy.

But Frondizi was a clever man and he also played his cards to balance out the power of the military. He created several organizations, can't remember the names right now, where he placed his people to try to counter the weight of the ministry of economy. ${ }^{15}$

Frondizi's response to the imposed situation involved setting up new economic bureaucratic organizations such as the National Commission of Foreign Investment and the Secretariat for Economic and Social Affairs of the Presidency, with the intention of sidestepping the Ministry of Economy in the formation and implementation of economic policy (Sikkink, 1993). However, the country's economic situation and military pressures forced Frondizi to commit himself to the IMF stabilization program and focus economic policy on cutting expenses, reducing the size of the state apparatus ${ }^{16}$ and liberalizing domestic markets that took away the intended weight from the newly created economic agencies.

This period coincided with the United States' aid program, Alliance for Progress, which requested Latin American governments to create or reinforce their longterm development planning mechanisms. After an Alliance for Progress meeting in Punta del Este (Uruguay) in 1961, at Frondizi's request, Alsogaray created the National Development Council-CONADE (Consejo Nacional de Desarrollo) by decree 7.290, and resumed central planning as a governmental practice. A former planning body director remembers the creation of CONADE as follows:

\footnotetext{
${ }^{14}$ Argentinean military and economist promoter of economic liberalism.

15 Author's interview, former Director of the National Planning Institute (INPE), Buenos Aires, Argentina, June 7, 2011.

16 In late-1958, Frondizi launched the Executive Committee of Rationalization (CEPRA) with the main thrust of reducing the cost of public administration and rationalize the state.
} 
Frondizi saw in the creation of CONADE a new opportunity to counterbalance the power of the Minister of economy in the economic policy making assigning to the new organization a real participation in the economic policy formulation. Of course, Alsogaray was reluctant to the creation of the planning agency, he did not create CONADE by personal conviction but because it was imperative to interact with the Alliance for Progress and to receive financing from international lending agencies and the U.S. Agency for International Cooperation.17

CONADE was, in theory, responsible for formulating long-term economic policy and building a national development strategy to pursue the political goals established by the national government, as well as advising the President on these matters (Bernazza, 2006). To accomplish these objectives, CONADE was structured as a collegial body chaired by the Ministry of Economy and directed by an executive secretary. CONADE's hierarchy was right below the President of the Republic.

Even though Frondizi's attempt to give CONADE an actual involvement in the economic policy making, it was Alsogaray, the Minister of Economy, who concentrated this power. ${ }^{18}$

Later on, Frondizi granted the planning agency with the task of preparing longterm sectoral plans (energy, transport, health, housing, etc.). He was reluctant to involve economic interest groups or political parties in the formulation of such plans, and despite receiving demands to include representatives of economic and social groups in the discussions of the development sectoral plans, CONADE did not invite interest groups (Wynia, 1978). As expressed by a former planning body director:

I remember that during this time CONADE prepared many sectoral policy documents but it was more an internal practice; these were not discussed outside with political groups and were not put in practice. ${ }^{19}$

President Frondizi almost exclusively trusted the economists and state technocrats from CONADE (Bernazza, 2006) who at that point were ECLA-trained economists.

17 Author's interview, former Director of the National Planning Institute (INPE), Buenos Aires, Argentina, June 7, 2011/

18 Author's interview, former Director of the National Planning Institute (INPE), Buenos Aires, Argentina, June 7, 2011.

${ }^{19}$ Author's interview, former planning body Director, Buenos Aires, Argentina, June 7, 2011. 
Frondizi also did not use Congress to ratify these plans; rather, Congress was usually only consulted after the plans had already been designed (Leyva, 2010).

In an attempt to enhance his narrow base of political support, Frondizi decided, in 1961, to reverse the banning of Peronism, which had been ordered by the military dictatorship in 1955, thus allowing its militants to participate in the 1962 local elections. Peronism won ten out of fourteen provincial governments. The military viewed this situation as a risky restoration of the President's alliance with the Peronists, which might force his abandonment of the IMF program (Wynia, 1978). In order to prevent such a change, the military overthrew Frondizi, replacing his government with the de facto civil government of José Maria Guido (1962-1963). Despite its short time in power, President Guido by executive decree 6337 of 1962 assigned CONADE new functions including the prioritization of public expenses in line with the general investment budget; defining investment lines for public works and responsibility for approving the investment plans proposed by other public agencies and line-ministries.

Thus far, the narrative of accounts allows the reader to understand the moment of the agency's creation. In terms of the alternative causal mechanisms it is possible to state the following. First, tuned with the structural instrumental approach the agency's creation responds to a political struggle among the various sectors that conformed the coalition allowing Frondizi into power. But contrary to the hypothesized causal mechanism there is no evidence that the agency itself sought to pursue and protect the interests of a specific coalition. Instead, the agency was created, as well as other agencies, in a reactive way, for President Frondizi to counterbalance the power of Ministry Alsogaray who had the support of the military. To this point there is also no evidence that the agency's design incorporated specific transaction costs to reduce attempts at changing the agency, rather the agency was directly created by Presidential decree. Second, there is strong evidence that the agency's creation responded to the influence of powerful external actor as the causal mechanism of the environmental perspective proposes. Indeed the agency followed the premises of the Alliance for Progress. However, internal actors were not passive receivers of this pressure, Alsogaray was happy to receive financial aid as compensation for creating the agency, and President Frondizi saw the opportunity to staff this agency with his closed allies yet again offsetting the power of Alsogaray.

In 1963, President Guido called for restricted elections, whereby Peronism was prohibited, and Arturo Illia from the Radical party was elected President (19631966). Taking advantage of an economy that had begun to recover from recession, President Illia dedicated his administration to economic expansion. Unlike 
Frondizi, Arturo Illia did not consider the services of the IMF experts or other foreign advisors in designing his economic policy (Wynia, 1978). Instead, Illia commissioned the design of his economic policy to experts from the ranks of the Radical Party.

When Illia won in 1963, Roque Carranza is placed as the head of CONADE, I was one of the first to be there. Who was Carranza? He was a man very close to the Radical party, an engineer who decided to make a planning organization and to build a plan. Carranza had lived in Chile, he had not worked in ECLA but he had been in that Chilean atmosphere. He came with the idea of ECLA's planning and CONADE absorbed an ECLA's delegation office that was operating in Buenos Aires. ${ }^{20}$

Based on Keynesian principles, these experts were inspired and divided into two separate streams. The first one was the economists who were preoccupied with the problem of generating economic recovery as quickly as possible, advocating the application of governmental resources to stimulate economic expansion. These specialists were appointed by President Illia in the Ministries of Economy and Treasury, as well as the Central Bank. The second stream comprised those following the structuralist doctrine developed by ECLA, who advocated for a longterm program of rural and industrial modernization directed at increasing productivity (Wynia, 1978). Representatives of this second group were appointed at the national planning agency, CONADE.

The team of professionals at CONADE was the kind of technical bureaucrats, many of them coming from an agreement that existed with ECLA. There were many Argentineans inside ECLA that belonged to the group coached by Prebish. They were people indoctrinated under the school of ECLA. The government with Illia invited these people and many of them were hired by CONADE. That was the spring time of CONADE, technical cadres were formed that later were absorbed during democracy; for example Bernardo Grinspun and Juan Sourrouille, ministers of President Alfonsin came from the group of people formed at this early stage in CONADE.21

During the message to Congress on May 1, 1966, President Illia said: “The executive has relied on an efficient and high-level technical agency for the

\footnotetext{
${ }^{20}$ Author's interview, former Secretary of Planning and Ministry of Economy, Buenos Aires Argentina, June 13, 2011.

21 Author's interview, National Representative for the province of Buenos Aires Buenos Aires 2007-2009, June 11, 2011.
} 
formulation of the National Development Plan. Public works, investments, both public and private, should be scientifically analyzed by CONADE, which also will set national priorities and a suitable pace of growth for the country" (Alvarez: n.d). This statement reflects President Illia's intention to improve technical capacity of the State in general and the planning agency in particular. In fact, besides the tasks of preparing a National Development Plan (1965-1969)22, CONADE was in charge of defining the short-term investment budget, as well as the monetary, credit and exchange rate policies. According to Ascher (1984), for the first time in Argentina all public budget requests were classified in both economic categories and as part of a specific government program, with the budgetary process becoming standardized and coordinated. Other highly technical tasks were taken away from other agencies and concentrated in CONADE at this time, particularly, the crafting of an input-output matrix, the construction of national accounts, and the design of the first unemployment national survey. According to a former planning body director:

These achievements were possible thanks to the support that President Illia gave to Richard Mallon. Carranza made an agreement with people at Harvard and brought Mallon to CONADE. Mallon came from the Institute of International Development of Harvard. Mallon helped train a group of excellent professionals inside CONADE, technicians, economists. CONADE made a large recruitment of people. It had like 300 people. $^{23}$

President Illia restructured CONADE by adding a vice-presidency (executive secretary $)^{24}$ and technical secretary to the organization, as well as four councilors representing the Ministry of Economy, the Ministry of Public Services, the Central Bank and the Federal Investment Council. Additionally, CONADE had to qualify its personnel in order to take over the aforementioned tasks. The agency not only absorbed the economic experts working in the ECLA's filial in Buenos Aires, but also started to hire professionals who demonstrated specific experience in economics and the field of planning and budgeting, as well as having a relevant university degree. ${ }^{25}$

22 In this plan, the government emphasized strategies to (i) stimulate agriculture by improving land use; (ii) promote the steel and chemical industries; and (iii) increase public investment in infrastructure.

${ }^{23}$ Author's interview, former Secretary of Planning and Ministry of Economy, Buenos Aires Argentina, June 13, 2011.

${ }^{24}$ Bernardo Grinspun was appointed by President Illia as the first executive secretary of CONADE

${ }^{25}$ Author's interview, early official of CONADE, Buenos Aires, Argentina, June 14, 2011. 
Moreover, CONADE promoted training scholarships and kept international technical assistance agreements, especially with ECLA and Harvard University. As mentioned by Mallon (2000), this fact contrasted with other key government ministries and agencies that were under control of patronage appointments.

Throughout this period, CONADE played an active role in the decision making process of the Argentinean public sector, by both legal mandate and ad hoc participation, giving the agency great influence over other public sector organizations (Otero, 1985). As a former director of the planning body points out:

That office had much influence over the government, undoubtedly because Carranza was a man very close to the President. Additionally we had the technical assistance from the Institute of International Development at Harvard, headed by Richard Mallon. So the office worked, the office had much influence over the government. While we were doing the plan, we were participating, at the same time, in daily decision making of economic policy. ${ }^{26}$

According to a former head of CONADE:

This situation was possible not only because the competent technical staff of CONADE, but also because of a very close friendship between President Illia and his CONADE director, Roque Carranza. ${ }^{27}$

In the same direction, an early official from CONADE and actual expert economic analyst stated:

The most interesting time of CONADE and its involvement with economic policy had to do with a personal circumstance, which is that in 1965 the general secretary of CONADE was Roque Carranza, who was a Radical, very close to the President. Carranza was a friend of Illia and other members of the government's economic team; from there on he sat at the table with them, he was taking positions on roundtable discussions. 28

\footnotetext{
${ }^{26}$ Author's interview, former Secretary of Planning and Ministry of Economy, Buenos Aires Argentina, June 13, 2011.

${ }^{27}$ Author's interview, former Director of CONADE and Ministry of economy, Buenos Aires, Argentina, June 14, 2011.

${ }^{28}$ Author's interview, early official of CONADE, Buenos Aires, Argentina, June 14, 2011.
} 
In line with Wynia (1978), Illia only appointed close associates in the economic policy posts due to the strong sense of union that bound party activists together, as well as the belief that only party loyalists deserved to make policy. "The Radicals had never been a wealthy party and had depended instead on the hard work of loyal activists for their electoral success (...) the one thing that allowed the party to survive for many years in the opposition and overcome occasional internal divisions, was the strong sense of fraternity" (Wynia, 1978, p. 118). In this sense, Illia refused to consider the creation of a coalition government.

Even though Illia's government succeeded in rising exports and enhancing technological progress in agriculture, other policies that were hostile toward the international organizations, ${ }^{29}$ the re-imposition of exchange rate controls and the excessive increase of labor benefits within decentralized agencies and state enterprises $^{30}$ polarized opposition towards the government (Mallon and Sourrouille, 1975). According to a former director of Planning:

Liberal business people and representatives from the financial sector were highly discontent with the administration because these sorts of policy decisions had been made without adequate private sector participation. ${ }^{31}$

Also Congress did not play a substantial role in building policy consensus; rather, its function was limited to the ratification of policies designed by executive officials (Wynia, 1978).

Although consensus building was not the principal concern of the CONADE economists ${ }^{32}$, the planning agency kept informative meetings with members of the budget and finance commissions of both the senate and chamber of deputies about the plan and economic policy in order to lessen criticism. However, these reunions had a consultative rather than a decision making character. The plan was also discussed with labor unions and economic associations, who, in general terms, rejected its content (Botana, et al 1973). By 1966, Illia's stubborn partisanship increased the alienation and distrust of political parties and interest groups. The

\footnotetext{
${ }^{29}$ President Illia decided to cancel foreign petroleum company contracts and withdraw the IMF standby agreement.

${ }^{30}$ According to Mallon and Sourrouille (1975), the most notable was the state railway deficit that accounted for almost 20 percent of total central government expenditure by 1965 .

${ }^{31}$ Author's interview, former Secretary of Planning and Ministry of Economy, Buenos Aires Argentina, June 13, 2011.

32 CONADE was concentrated in the solution of the many technical problems associated with creating a development plan, mainly the collection from scratch of social data.
} 
unconformities from both factions resulted in Illia's government being ousted by military forces, followed by the designation of the facto government of General Juan Carlos Onganía (1966-1970).

At this point, and after the initial political struggles under Frondizi, CONADE took an institutionalized organizational trajectory. All sources point that the agency started its golden period. The agency was allotted with functions that were actually implemented on the ground; the agency was now staffed with permanent and qualified personnel that socialized and reproduced its technical profile through scholarships and exchanges with ECLA and Harvard permeating into CONADE. These elements are empirical evidence that match some of the causal mechanisms theorized by both the cultural and environmental institutional approaches. However, according to the empirical accounts collected, much of these achievements were only possible because of the strong affiliation between President Illia and Roque Carranza, who in turn saw in the agency the adequate means to project the President's government plan.

After this coup d'etat, called the Argentinean Revolution (1966-1973), the military government dismantled the preexisting political institutions, removed all the political appointees of the previous regime from public offices, including middle and upper level bureaucrats and technocrats, and started a restructuring process of the public administration. However, CONADE survived due to the military recognition of its technical work in the preparation of Illia's development plan (Mallon, 2000). In this context a former director of the planning organization remembered:

I think Onganía and the military were interested in preserving what CONADE had learned to do, but of course not the people that were there. Those people followed ECLA's ideas not much tuned with the military view on economics. ${ }^{33}$

The public sector reorganization process initiated by President Onganía consisted of three phases. Among them was the reorganization of the planning scheme (law 16.964), which involved the creation of two planning branches: the National Planning and Action System for Development, coordinated by CONADE; and the National Planning and Action System for Security, coordinated by the National Council of Security CONASE. The former was in charge of economic and development planning, while the later was responsible for defense and security planning (Cordone, 2004).

33 Author's interview, former director of planning body, Buenos Aires Argentina, June 14, 2011. 
The specific functions of CONADE included formulating policy and a national strategy on long term development, as well as imprinting directives to sectoral and regional authorities responsible for medium- and short-term policies (Arceneaux, 2001). In this sense, ten Sectoral Development Offices and eight Regional Development Offices were created within the jurisdiction of various state secretariats and regional governments. ${ }^{34}$ These offices had the duty of defining their own sectoral development targets and plans in coordination with CONADE. On the other hand, CONASE was expected to plan policies and strategies related to security; integrating the internal, foreign and defense policy with security affairs and imparting directives to authorities responsible for security (Arceneaux, 2001). Like CONADE, CONASE was directly subordinate to the President. To complete their functions, both CONADE and CONASE were authorized to demand facts, statistics, and other information directly from national ministries, secretaries of the state, commanders in chief, territorial governors, municipal intendments and other public bodies.

According to Potash (1996), the ultimate goal of the planning system as a whole was to harmonize economic development and national security to provide an institutionalized procedure for the military to comment on proposed legislation that related to development and security.

The military regime understood the economic planning system as the materialization of the combination of the traditional military planning, national security doctrine and a kind of modern scientific managerial way to administer the state. In this sense, CONADE was very convenient for them, it gave them the means to articulate what they wanted. ${ }^{35}$

Smith (1989), Wynia (1989), Potash (1996) and Arceneaux (2001) coincide in highlighting that Onganía's vision of the planning system, which was meant to closely coordinate economic development and national security, gave the military regime an institutional input in economic decision making and a way of taking politics away from what was viewed as essentially technocratic work. Neither the rules nor the economic policies implemented by the government were a topic of debate or assessment by the private sector. The central role in Ongania's thoughts of building a technocratic bureaucracy in the Argentinean public administration

\footnotetext{
${ }^{34}$ Cordone (2004) highlighted that the ministries of Public Health, Education, Housing, Social Security, Agriculture, Industry, Energy, Mining, Transport and Public Works, and Communications were the bureaus in which sectoral planning offices were created. In the same way, the regional governments of Patagonia, Comahue, Cuyo, Noroeste, Noreste, Centro, Pampeana, and Metropolitan Area had a regional planning office.

${ }^{35}$ Author's interview, former ILPES Director, Santiago de Chile, June 23, 2011.
} 
was not accidental. According to Cavarozzi (1997), it responded to the conviction that the real problem of Argentina was fundamentally a political one. Therefore, what should be done was to end the complicated and inefficient intermediation of the political parties, parliament and corporate interests in order to allow economic growth to take-off.

By freeing the President from any obligation to bargain with private citizens over the policies he selected, Onganía and his associates believed that they had at last made it possible for the nation's chief executive and the technocrats who assisted him to make policies for the society as a whole rather than according to the demands of a few selfish groups. ${ }^{36}$

The regime's attempt to eliminate politics and technocratize the process of state economic decision making was reflected in the appointments made by Onganía. The President commanded major qualitative changes in the level of technical and scientific knowledge at the top of the state apparatus, and especially in the economic decision making bodies. In this sense, Onganía selected Adalberto Krieger Vasena, PhD economist at Universidad de Buenos Aires, as head of the Ministry of Economy, and José Maria Dagnino Pastore, PhD economist from Harvard University, as a chief of CONADE. In words of a former ILPES director:

These people were known more for their technical expertise than for their affiliation with a political party or economic group. ${ }^{37}$

While Krieger Vasena concentrated on short term economic policies for structural adjustment, Dagnino Pastore centered on long-term national economic development and attracting foreign international cooperation. In this context, former planning director states:

In terms of economic policy, Onganía gave us autonomy to do our job. While Krieger Vasena had immense authority to carry on economic policies to restore business confidence, cut inflation, and to control the money supply, wages and prices, I centered myself in CONADE in preparing projects to be presented to international organizations in order to access international financing, and in preparing the National Development Plan. ${ }^{38}$

\footnotetext{
${ }^{36}$ Wynia, Gary (1978) Argentina in the Postwar Era. Politics and Economic Policy Making in a Divided Society. Alburquerque, University of New Mexico Press, p. 175.

37 Author's interview, former ILPES Director, Santiago de Chile, June 23, 2011.

38 Author's interview, former Director of CONADE and Ministry of economy, Buenos Aires, Argentina, June 14, 2011.
} 
Following the stand of Krieger Vasena, the government adopted a series of economic measures centered on prices and wages. According to Mallon and Sourrouille (1975), the government raised the exchange rate from 280 pesos per dollar to 350, increased taxes on traditional exports and improved tax collection, adjusted the wage rates of different unions, increased tariffs of public utilities, limited firms' possibility to increase prices excessively and signed a new standby agreement with the IMF to hold debt. Bernazza (2006) expressed that these economic measures resulted in reducing the wages of popular sectors, with a negative impact on income distribution, as well as the failure of the industrialization model. This created an uprising from labor unions, students and intellectuals, which resulted in a general rebellion in the city of Cordoba, violently repressed by government. The Cordobazo weakened Onganía's authority by undermining his claim to have stabilized the country. Shortly after, the military withdrew its support of Onganía's government, resulting in his fall in 1970.

The military junta appointed General Roberto Levingston (1970-1971) as new President. Levingston changed the cabinet and selected Carlos Moyano, a Krieger Vasena's disciple, as Minister of Economy. However, the main union organizations rejected this appointment because they considered Minister Moyano as a continuation of Vasena's liberal policies. Conflict between the administration and union organizations subsequently forced President Levingston to replace Moyano with Aldo Ferrer as Minister of Economy. ${ }^{39}$ In an attempt to mitigate the union criticism, Ferrer followed a program of economic expansion, the creation of jobs, national industry stimuli and nationalization (argentinización) of the economy. ${ }^{40}$ Furthermore, Ferrer approved a wage increase of 19 percent, rising to 30 percent by 1971 (Wynia, 1978).

Levingston appointed General Juan Enrique Guglialmelli as director of CONADE. The planning organization under Gugliamelli's direction came forward as the most articulated and politically significant criticism against the economic policy followed by the Ministry of Economy. In particular, Gugliamelli strongly opposed polices regarding wages and labor unions rights.

\footnotetext{
${ }^{39}$ Author's interview, former CONADE official, Buenos Aires, June 2, 2011.

40 According to Smith (1989), this nationalism constituted a demand for a greater participation of the state and national capital in the process of industrialization. The argentinización was an attempt to reorient and redistribute bank credit in favor of locally owned firms.
} 
Levingston replaced Gugliamelli and CONADE retreated. It was difficult times for CONADE as it opposed the economic policies that Krieger had started. ${ }^{41}$

To avoid further controversy and opposition by organized groups, President Levingston simply solved the internal dispute by accepting the resignation of Gugliamelli and appointing Javier Villanueva as a new director of CONADE.

Villanueva reassumed the debate over the National Development Plan that had started during Onganía's government, opening its discussion to different sectors of society, including entrepreneurs and union leaders. As a result, CONADE prepared a final version: the National Development and Security Plan of 1971-1975. The axis of this plan was the impetus of national capital, economic integration and industrial exports (Leiva, 2010). However, increasing inflation and the large external imbalance exacerbated the economic and social crisis, resulting a few months later in the replacement of President Levingston with General Alejandro Lanusse (1971-1973).

President Lanusse, aware of the deterioration of the military regime of the Argentine Revolution, set up the Great National Agreement (Gran Acuerdo Nacional). This agreement sought to incorporate persons opposed to the regime inside the policy making apparatus in an attempt to limit, and reverse, the political defeat of the Cordobazo (Smith, 1989). In the economic policy making realm, the regime proposed the creation of a Social and Economic Council to advice on economic matters. The economic policy making apparatus was opened to discussion with other previously excluded sectors (unions, business associations), which ultimately led to political and clientilistic pressures and the dismemberment of the centralized bureaucratic institutions. Lanusse abolished the Ministry of Economy, replacing it with the new Ministry of Treasury and Finance. Furthermore, Lanusse eliminated CONADE and CONASE, merging both as part of a new Secretary of Planning and Government Action. Additionally, Lanusse lifted the ban on political parties, including Peronism, and called for free elections in 1972. The presidential elections were won by Hector José Campora (Justicialist party), who subsequently resigned only forty-nine days later, together with his Vice-President. New elections were called, this time won by Juan Domingo Perón with $63 \%$ of the votes, returning to power in October 1973.

Reaching this point in time, the historical events showed subsequent transformations of CONADE now in the context of three military governments.

${ }^{41}$ Author's interview, former Secretary of Planning and ministry of economy, Buenos Aires, June 13, 2011. 
The 1966 coup d'état that brought Onganía into the presidency can be read under the cultural institutional approach as the upcoming of a critical juncture. However the structure of the agency as well as its technical essence continued barely unchanged. The changes came from the type of personnel and additional functions introduced that permitted the military with the adequate place to link together economic development with national security. Notwithstanding, when political turmoil started to demand a significant higher political and economic participation in policy making, the rather less technically oriented military Presidents Levingston and Lanusse ceded to this pressure letting go off the agency.

\subsection{The National Institute of Economic Planning-INPE}

One of Perón's first administrative decisions, through the Law of Ministries, was to dismantle the Secretary of Planning and Government Action, created by Lanusse, replacing it with a revived Ministry of Economy, within which Jose Gelbard ${ }^{42}$ was appointed as Minister. Moreover, under the Ministry of Economy, Peron created the Secretary of Planning, Programming and Economic Coordination and the National Institute of Economic Planning (INPE), headed by Benjamin Hopenhayn.

I took part of Peron's government with the clear mandate to coordinate the planning of the government's economic policy and to promote social and economic development. We did this job from inside INPE with the collaboration of Gelbard as ministry of economy. As a result of this work, the triennial 1974-1977 Liberation and Reconstruction plan. ${ }^{43}$

The National Institute of Economic Planning assumed the accumulated body of data, information and knowledge shaped during the course of CONADE's existence (Bernazza, 2006). However, unlike CONADE, INPE was placed inside the Ministry of Economy, thereby reducing the agency's autonomy. According to Leiva (2010), this decision responded to a strategy of preventing the dissociation between short and long run policy.

Though, this can better be explained as an attempt by José Gelbard to control the economic policymaking. ${ }^{44}$

\footnotetext{
${ }^{42}$ Argentine businessman and political activist.

43 Author's interview, former Director of the National Planning Institute (INPE), Buenos Aires, Argentina, June 7, 2011.

44 Author's interviews, National Representative for the province of Buenos Aires Buenos Aires 2007-2009, June 11, 2011, and former ILPES Director, Santiago de Chile, June 23, 2011.
} 
The economic policy led by Gelbard, called the Social Pact, was based on a consensual system of legitimacy that combined parliamentary democracy with notions of corporatist representation. It essentially comprised the elaboration of a commitment document called National Reconstruction, Liberation and Social Justice, in which the General Labor Confederation and the General Economic Confederation ${ }^{45}$ agreed on the government's economic objectives, especially freezing prices and rising wages. The Social Pact also needed to be ratified by the Parliament.

Founded on the Social Pact, Peron requested the elaboration of a national development plan to the planning agency. With this purpose, INPE hired a technical team from ECLA. The main diary of Buenos Aires, El Clarin, reported on April 27, 1973:

The economic planning sub-secretary, Orlando Dadamo, sought the support from the United Nations Organism, to overcome the lack of local planning experts at the Ministry of Economy. However as noted by several people it was also a clever step, having technicians from ECLA served as an indirect means for Argentina to be endorsed by a global organization, guaranteeing the country's access to international credit. ${ }^{46}$

By decree $N^{\circ} 185$ of November 1973, the three-year plan (1974-1977) was launched. This governmental project was centered on increasing the volume of rural production and exports through augmented state intervention. Along with the budgeting office, INPE also prepared and allocated the national investment budget according to the plan's targets and goals. According to Benjamin Hopenhayn:

(...) We came inside any Ministry because we were the ones assigning and managing the money from the State (...). The relationship with the budget director was key as it was people knowing of that relationship. It was also key that Gelbard sent governors to talk to us. It shows the link with politics and the link with the bureaucracy.47

\footnotetext{
${ }^{45}$ Representative group of industrialists.

${ }^{46}$ Cited in: Bernazza, Claudia Alicia (2006) La planificación gubernamental en Argentina. Experiencias del período 1974-2000 como puntos de partida hacia un nuevo paradigma. Facultad Latinoamericana de Ciencias Sociales-FLACSO Argentina, PHD thesis, pp. 129. The translation is mine.

${ }^{47}$ Montagú, Haroldo (2011) “Benjamin Hopenhayn: el Optimismo de la Voluntad". Centro de Estudios para el Desarrollo Economico Benjamin Hopenhayn, N², p. 11.
} 
In 1974, the social pact among organized labor, industrialist and government ended due to the oil crisis of October 1973. Argentina's favorable terms of trade were unexpectedly reversed as oil prices sharply exceeded the price of primary exports in international markets. Industrialists were the first to abandon the price freeze, followed by the trade unions demanding large wage increases (Smith, 1989). This new economic crisis was at its peak when President Peron died on July 1, 1974. He was succeeded by his Vice-President and wife, Maria Estela Martinez (1974-1976), who had little opportunity to confront the unprecedented inflation rate, constant labor unrest, rising foreign debt and collapse of entrepreneurial confidence (Wynia, 1978). President Martinez was overthrown in 1976 by a military coup that gave rise to the self-named National Reorganization Process (1976-1983).

Under General Jorge Rafael Videla, the National Reorganization Process revised the country's approach to development. According to Smith (1989), the new economic team, led by the Minister of Economy, José Martinez de Hoz, rejected the economic project previously implemented by Onganía's regime because he considered it insufficiently orthodox. He also blamed the Keynesian-inspired development model of import substitution industrialization followed by Peronists, radicals and developmentalists for the economic problems that Argentina was facing. Refuting these earlier growth strategies, Martinez de Hoz instead proposed the implementation of an economic model based on economic liberalization and the reinsertion of Argentina's economy in the world's economy (Smith, 1989).

At this point, the main economic premise was to reduce the size and role of the state in the economy. The military regime started to follow the economic guidelines of the Chicago School, which had been implemented by the government of Augusto Pinochet in Chile. In the words of Jose Martinez de Hoz, Minister of Economy of the National Reorganization Process:

[The State] must intervene in the economy directly when there is no possibility or interest of private enterprise to do so. The latter has the responsibility to carry out productive economic activity, notwithstanding the role of the State to determine the superior orientation of the economy and control it through major economic and financial policy instruments. ${ }^{48}$

The economic plan was presented on April 2, 1976, with the explicit aim of stopping inflation through the imposition of fiscal austerity, improving the trade balance through the expansion of agricultural exports and encouraging foreign

48 Cordone, Hector (2004). "Reseña Histórica sobre la Planificación en la Argentina". Documento CEIL-PIETTE, p. 21. The translation is mine. 
investment. Martinez de Hoz also introduced several measures aimed at restoring business confidence, including a banking reorganization scheme (Wynia, 1978). The fiscal measures conformed to International Monetary Fund demands, which also requested the development of mechanisms to allow prioritizing and assessing public investment. In 1977, INPE was restructured in response to this demand. According to former ILPES director:

At that time I was working with ECLA in Buenos Aires and even though we had poor relation with the military government, we had to do what we were asked. So sometime around 1978, 1979 we were convened because a law had been passed in which all public projects exceeding certain amount had to receive approval by INPE. So they called us in ECLA to help them build a project valuation system. ${ }^{49}$

The agency was assigned with three working areas: (i) short-term projections to assess the consistency of the national budget; (ii) project analysis and evaluation; and (iii) global programming. Moreover, the military government established the requisite that all public investment projects overpassing certain amount were to be pre-approved by INPE. According to Otero (1985), the agency was granted with the following functions:

- Developing the information system required for managing public investment

- Public investment forecasting and analysis

- Elaborating a three-year plan for public investment (1978-1981)

- Preparing provincial annual investment budgets in collaboration with the Ministry of Interior and Ministry of Finance

- Formulating the central government and state enterprises' annual budget

- Collaborating with the Finance Ministry on the privatization process

The military government in general and Videla in particular were aware of the urgency of providing the regime with a legitimacy that extended beyond the strictly economic and military fields. For the military regime, it was necessary to have a theoretical political justification for their actions. In this sense, Videla maintained that it was essential to develop a National Project in which the government's fundamental medium- and long-term policies were established. Additionally, Videla had to contain the criticism and resistance from a section of the armed forces who opposed the Ministry of Economy's anti-statist policies (Canelo, 2004). Brigadier General Ramon Diaz Bessone, who had spent time in

${ }^{49}$ Author's interview, former ILPES Director, Santiago de Chile, June 23, 2011. 
France and was "delighted with the French experience in planning" 50 suggested to Videla the creation of an organization that articulated the functions of planning, consultation and decision making in order to interpret the general interest and build a national government project.

As a result, parallel to INPE, in September 1976 the military government decided to create the Ministry of Planning, Law 21.431. The new ministry was introduced as an organization responsible for coordinating between ministries and other public organizations. Videla appointed General Diaz Bessone as Minister, who was to operate as direct adviser to the President and act as delegated President in case of the President's absence.

Unlike other planning agencies created before in the country, which had had a technical nature, the Videla's Ministry of Planning was strictly political, with the sole function of justifying the regime. ${ }^{51}$

Following the original design conceived by Diaz Bessone, Law No. 21,431 dispensed the function of developing and updating the National Project to the Ministry of Planning, which was then to be submitted and approved by the Military Junta. Finally, Law No. 21,431 stipulated that the Ministry of Planning should provide the scenarios for consultation and receiving input from the community. This agency adopted all other planning functions, besides public investment, that INPE had carried out prior to the military coup.

Major political figures and advocates of economic liberalism such as the Minister of Economy Martinez de $\mathrm{Hoz}$ and former Minister of Economy Alsogaray soon opposed the operation of the Ministry of Planning. According to Canelo (2004), the creation of the Ministry of Planning came into collision with various objectives stated as definitive by the military junta. First, from an administrative perspective, the creation of the Ministry of Planning conspired against the objective of rationalizing public administration announced by the Ministry of Economy. Second, in institutional terms, the responsibility for centralizing and coordinating activities with other ministries granted the Ministry of Planning the character of supra-ministry, which undermined the autonomy and power of the Ministry of Economy. Finally, in ideological terms, the idea of state planning, which assigned the state the capacity to set economic and political targets, was contradictory to the tenets of economic liberalism. Confronted with this criticism, Videla withdrew his support to Diaz Bessone. Diaz Bessone's intention to position the Ministry of Planning as a "supra ministry" that marked the basic function of all areas of the

\footnotetext{
${ }^{50}$ Author's interview, former ILPES Director, Santiago de Chile, June 23, 2011.

${ }^{51}$ Author's interview, former ILPES Director, Santiago de Chile, June 23, 2011.
} 
State could not overcome the fact that the real power was under the Ministry of Economy, and especially in the hands of Minister Martinez de Hoz, who was the number one minister of the regime.

On December 31, 1977, Diaz Bessone resigned as Minister of Planning and requested to the Military Junta his retirement from active duty. Nine months later, through Law 21.909 of 1978, the military government abolished the Ministry of Planning, creating in its place the Secretary of Planning under the jurisdiction of the Presidency of the Republic (Otero, 1985). The Secretary of Planning kept the same functions previously assigned to the Ministry of Planning, although planning efforts were in contradiction with the reforms of trade and financial liberalization and reducing state intervention in the economy. Subsequently, economic planning was quickly dismantled, along with other mechanisms of state intervention.

Cornered with a growing external debt, persistent inflation and the cost of defeat in the Malvinas' war, as well as the international pressure for human rights violations, the military government decided to call elections after seven years of martial dictatorship. Democracy returned to Argentina in 1983, with Raul Alfonsin (1983-1989) of the Radical Civic Union party victorious.

Transformations of the planning agency along these years, from the creation of INPE by the Peron government to the splitting of the planning body into two branches, INPE and the Ministry of Planning provide insights that feed into some of the causal mechanisms hypothesized. The return to democracy represents yet another critical juncture in which the Peronist government responded by changing the overall structural administration of the Argentinean public sector, including the replacement of CONADE by INPE. This strategy responds to an attempt by the government to withdraw from the closed and non-participatory structure left by the military government. However, INPE only took a formal change in terms of its name and hierarchy and continued performing almost the same functions as CONADE. Along with the instauration of the new military government two important ruptures took place. First a radical political change in the regime, and second the change of paradigm in the economic model. Matching the theorized hypothesis of the task specific approach, evidence supports that the agency undertook new functions in project appraisal to adopt to the new economic model (without eliminating the prior functions) and that this change, along with the environmental perspective, obeyed to the recommendations of the IMF in the context of stabilization program followed by Argentina.

Although the above-mentioned events are insightful they hardly provide a consistent explanation of the factors that account for the institutional 
transformations of the planning agency. The one evidence that is consistent throughout these years is that changes in the planning body are closely related to the preferences of the President, and that this actor does not encounter any opposition or transaction costs to dismantle and/or transform this agency or any other. A good example is the creation, by military President Videla, of the Ministry of Planning in duplication with INPE, that despite it being counter to the liberal economic premises of the time, he nonetheless went forward with its creation.

\subsection{The Secretary of Planning}

Alfonsin's government faced the most acute economic crises that Latin America had seen since the great depression of 1929, called the lost decade. Fiscal deficit, balance of payments difficulties, macroeconomic instability and recession characterized the Argentinean economy during the 1980s (Murillo, 2000: 140). In an effort to deal with this crisis, Alfonsin turned to the radical economic scheme that had been used during President Illia's term in office twenty years earlier. Bernardo Grinspun, Illia's former sub secretary of CONADE, was appointed as Minister of Economy, and Roque Carranza, Illia's former CONADE director, as Minister of Public Works and Services. Additionally, Alfonsin abolished both the INPE and the Secretary of Planning, and created a new Secretary of Planning through the Law of Ministries of 1983, headed by Juan Vital Sourrouille.

Sourrouille was Secretary and I was deputy Secretary. The Secretary sought to advise the President on the main lines of action. Juan Sourrouille was a well-respected man among the economic team and by the Radicals. His opinions were well received so some of the policy guidelines that we came forward with were discussed or assumed by the President, of course those that interested him. ${ }^{52}$

The economic team responded to the crisis with a nationalistic economic policy focused on reducing external debt, fiscal deficit and inflation volatility. Grinspun applied a Keynesian policy, founded on ECLA's principles, focused on strengthening the domestic market by raising wages, increasing public expenditure and controlling the prices of public services. ${ }^{53}$ Additionally, the government decided not to follow the IMF recommendations and threatened the international institution with declaring moratorium of payments (Murillo, 2000).

\footnotetext{
52 Author's interview, former deputy director of Secretary of Planning, President of the Argentinean Central Bank, Ministry of Economy and ECLA director, Buenos Aires, Argentina, June 9, 2011.

${ }^{53}$ Based on author's interview, former CONADE and Secretary of Planning official, Buenos Aires, Argentina, June 1, 2011.
} 
During this period, the Secretary of Planning continued under the jurisdiction of the President of the Republic with the main objective of advising the President on issues related to economic planning and development. According to Otero (1985), the tasks allotted to the Secretary of Planning were as follows:

a. Formulate medium-term policy goals

b. Set mechanisms to harmonize sectoral planning with general planning

c. Develop plans, programs, economic and social projects

d. Fix regional development goals, along with the Ministry of Finance

e. Participate in the preparation and control of the national budget

f. Evaluate programs and projects established by the National Plan

g. Manage international cooperation initiatives

The planning body produced a document named Guidelines for a Growth Strategy 1985-1989, which never effectively turned into a National Development Plan due to the urgency of working on the short-term problems of macroeconomic instability. ${ }^{54}$ Runaway inflation and the disarticulation of the productive structure brought upon by the neo-liberal project implemented by Martinez de Hoz contributed to the failure of the economic strategy advanced by Grinspun, with annual inflation reaching $625 \%$ towards the end of 1984 .

The economic policies followed by Grinspun led to confrontations with organizations representing business interests. Entrepreneurs strongly criticized state intervention in the economy, especially price controls (Smith, 1989). Moreover, the International Financial Institutions were discontent with Grinspun's management of the economy and his constant battles with these institutions while discussing the Argentinean debt (Leiva, 2010).

In 1985, Alfonsin shifted the heads of the Ministry of Economics and the Secretary of Planning, with Juan Vital Sourrouille appointed as Minister of Economy and Bernardo Grinspun signed up as director of the Secretary of Planning. As a former ECLA director states:

${ }^{54}$ Author's interview, former Secretary of Planning official, Buenos Aires, Argentina, June 1, 2011. 
A new economic policy was needed and Sourrouille was a Harvard trained economist whose academic ideas were well respected by the President, by the entire team of radical government, and by the international financial community. On the other hand, even though Grinspun policies had had openly failed he was an old Radical that could not be easily taken out of government. So, the planning agency was a post from which he could continue contributing with the economic team. Of course, Grinspun was not satisfied with his switch to the Secretary of Planning. ${ }^{55}$

The urgency of working on macroeconomic issues, combined with Grinspun's displeasure with his new position, further contributed to blurring of the planning body. According to a former ILPES director:

Very soon, roles were shifted by Alfonsin. Sourrouille is placed in the Ministry of Economics, receiving all credits, while Grinspun is sent to the planning agency like a consolation prize. Since then, the planning agency loses position within government and has little saying in the economic policy decisions. Here comes to play that old saying that urgency overshadows importance; urgent matters to address short-term macroeconomic policies are shifted over to the Ministry of Economics with Sourrouille in the frontline of this battle. ${ }^{56}$

In June 1985, Sourrouille launched his economic strategy: the Austral Plan. The plan primarily consisted of establishing a new currency with devaluation against the dollar reaching 18 percent; imposing wage and price freezes, with citizens urged to denounce violators; reducing the budget deficit through large increments in charges of government produced services; and restrictions in the printing of money. ${ }^{57}$ Due to the Austral Plan, the Ministry of Economy turned out to be an important and very visible figure in Argentina:

\footnotetext{
55 Author's interview, former deputy director of Secretary of Planning, President of the Argentinean Central Bank, Ministry of Economy and ECLA director, Buenos Aires, Argentina, June 9, 2011.

56 Author's interview, former ILPES Director, Santiago de Chile, June 23, 2011.

57 Smith, William (1989) Authoritarianism and the Crisis of the Argentine Political Economy. Stanford: Stanford University Press, pp. 279-281
} 
I tell you that on 1986 he was the most important person in Argentina, more than the President. He appeared on national television channels almost daily. The finance minister went on to be everything to us. ${ }^{58}$

Meanwhile, Grinspun published a document entitled National Development Plan 1987-1991. According to Leiva (2010), this plan was fashioned in a traditional way: first, a diagnosis of the economy, followed by economic forecasts; then quantitative goals for the external balance, exposure of public sector accounts and definition of public and private investment goals with specific sectoral targets. However, once again, the profound economic problems impeded the relevance and implementation of the plan.

Despite some initial success in limiting inflation, the General Confederation of Labor and industrialists started to demand wage increases and more flexibility in prices. Both political forces pushed for a revision of the Austral plan. Loosening the controls immediately produced accelerated inflation and a further increase in the budget deficit. The economic team was forced to sign an agreement with the IMF promising to carry out a structural adjustment program (Smith, 1989).

In 1989, President Alfonsin resigned several months before his presidential term was due, transferring government to the elected President Carlos Menem (19891999), from the Peronist party. According to Oszlak (2002), the decision was taken after recognizing that the Radical government was absolutely helpless in handling macroeconomic and social policies, in the face of the uncontrolled hyperinflation, massive rioting and looting and the deterioration of socioeconomic indicators.

The severe economic crisis faced by Argentina during this period, together with the urgency to bring about shock economic measures to confront the situation, rendered the planning organization unnecessary and almost outdated. Under such episode and following the causal mechanisms hypothesized by both, the cultural and task specific theoretical perspectives, the expectation would point at the elimination of the agency. However, the role of the President shows up again in shaping the agency's trajectory. For President Alfonsin, the agency granted him the opportunity to post important and historical figures of the Radical Party in a high-level position. Thus Alfonsin, almost ignoring the agency's redundancy decided to keep it.

58 Author's interviews, National Representative for the province of Buenos Aires Buenos Aires 2007-2009, June 11, 2011. 


\subsection{The Ministry of Federal Planning, Investment and Services}

President Menem's administration took office in July 1989 in the midst of a hyperinflationary burst, which significantly reduced his room for maneuver. In an effort to curb this situation, President Menem decided to concentrate power in the executive by means of congressional delegation and the use of urgency decrees (Ferreira and Goretti, 2000).

Congress enacted the Administrative Emergency Act and the Economic Emergency Act (Law No 23.696 of 1989), delegating authority in the Executive regarding privatization and reduced public expenditure. ${ }^{59}$ Furthermore, through this Law, President Menem was granted with the authority to issue need and urgency decrees. In this context, Menem embarked upon a two-phase radical economic reform: the first stage focused on dismantling the statist and inwardoriented structure established under Peron and initiating a program of market oriented reforms such as trade liberalization, privatization, deregulation and an adjustment of the public sector; while the second stage, consisted of enacting his monetary policy (convertibility law ${ }^{60}$ ) and fiscal reform. From July 7, 1989 to August 23, 1994, President Menem issued 335 need and urgency decrees (Ferreira and Goretti, 2000).

The bulk of these reforms were implemented by the Ministry of Economy, under Domingo Cavallo. Together with a team of technocrats, the Minister of Economy transformed into Menem's number one ministry. Cavallo modernized the ministry's information services, recruited a cadre of highly trained technical experts to fill bureaucratic positions and subordinated all units of the executive branch involved in economic matters (departments such as energy, finance, industry and trade) to the Ministry of Economy. Moreover, the Secretary of Planning was renamed as Secretary of Economic Programming and transferred back from the presidency of the Nation to the Ministry of Economy. ${ }^{61}$ In the words of a former ECLA director:

\footnotetext{
${ }^{59}$ According to Ferreira and Goretti (2000), Menem's concentration of power was benefited by two facts. On the one hand, the Justicialist Party was the largest in both Houses of Congress. On the other hand, public opinion demanded efficient government and centered its demands in the Executive, who was better prepared to react quickly to economic crises. ${ }^{60}$ Law 23.928 fixed parity of the peso in Argentina and the U.S. dollar.

${ }^{61}$ According to Leiva (2010), this fact further reduced the hierarchy and influence of the planning body in the Argentinean public sector.
} 
This ministry became powerful and forceful actor, from where almost all the need and urgency decrees were issued. ${ }^{62}$

In 1994, the Argentinean Constitution was changed, granting the President power to initiative bills and veto proposed laws passed by Congress, as well as limiting the President's authority to issue urgency decrees to very exceptional circumstances. However, Menem still issued 210 need and urgency decrees under the new Constitution. President Menem was re-elected in 1995 (Ferreira and Goretti, 2000).

In 1999, Fernando de la Rua (1999-2001) from the Civic Radical Union party won the presidential elections. President de la Rua had to face rising domestic debt as well as the macroeconomic and social problems that resulted from the implementation of Menem's economic policy, especially the convertibility law. Eventually, during the first year of the 2000s, Argentina confronted an economic stagnation that triggered the political, economic, financial and social crisis that resulted in the resignation of President de la Rua, with the provisional government of Eduardo Duhalde taking office (2002-2003) (Wylde, 2011).

Under the administration of Nestor Kirchner (2003-2007), Argentina witnessed economic recovery, in a recuperation rooted in Keynesian policies. President Kirchner withdrew some privatizations and deregulations programs initiated by Menem and increased public investment, especially in public works, housing and infrastructure. Moreover, Kirchner augmented real wages and pushed through a social-security reform that extended access to unemployed and informal-sector workers. Finally, Kirchner renegotiated debt worth around 30 percent of the defaulted sum (Levitsky and Murillo, 2008).

This new state activism was reflected in the revitalization of planning. Under the Law of Ministries 26,338 of 2003, Kirchner created the Ministry of Federal Planning Investment and Services. During the process of creating the Ministry of Planning, various policy areas were shifted away from several agencies and put under the responsibility of the Ministry; for instance (i) energy and communications were transferred from the Ministry of Finance; (ii) civil works, urban development, housing, atomic energy and water issues, from the Presidency of the Nation; and (iii) mining and transport, from the Ministry of Production (decree $\mathrm{N}^{\circ} 1283$ of May, 2003). In the same way, by decree $N^{\circ} 1283$ of May 2003, the new Ministry of Federal Planning, Investment and Services was given regulatory and public

\footnotetext{
62 Author's interview, former deputy director of Secretary of Planning, President of the Argentinean Central Bank, Ministry of Economy and ECLA director, Buenos Aires, Argentina, June 9, 2011.
} 
investment functions. The Ministry of Planning is currently responsible for assisting the President's Office in the design and implementation of public policies related to transport, communications, mining, energy, sanitation, public works, housing, water resources and territorial development.

Since its creation, the Ministry of Federal Planning, Investment and Services has characterized by two aspects: concentration of power and agglomeration. Regarding the first one, President Kirchner appointed Julio de Vido, who continues to hold tenure as Minister of Planning. Almost since his appointment, De Vido has been the most influential figure in the cabinet. The diary La Tercera highlights this fact as follows:

Julio de Vido, the powerful Planning Minister of Argentina, embodies the most laudable strengths and some weaknesses of Kirchnerism. De Vido has hold for eight years the directorate of this ministry key for the model of import substitution and inward development imposed by the Casa Rosada. ${ }^{63}$

In the same way, a former director of the planning body states:

Well this Ministry was done by President Kirchner and he placed there a person of his entire trust, de Vido. One thing Kirchner knew was managing power, so he tried concentrating all power in one person, through that Ministry he could control everything. If I say what I think of the Ministry, I can go to jail. Here they place fines to economic think tanks that contradict the official inflation statistics. They say that this confuses consumers and generates economic panic. What can I say, that Ministry is holding in one hand public works and everything else. I haven't seen concrete studies but there are some people trying to put some order into projects; that ministry is really powerful. ${ }^{64}$

The second aspect is agglomeration. The Ministry of Federal Planning has subordinated under its domain the task of defining, implementing, evaluating, budgeting and regulating the policies of energy, communications, civil works, urban development, housing, atomic energy and water issues. Additionally, the Ministry of Planning controls the allocation of both public investment budget and

\footnotetext{
${ }^{63}$ Navia, Patricio (2011) “El ministro más poderoso de Cristina K". La Tercera, 12 de noviembre

${ }^{64}$ Author's interview, former Director of CONADE, Buenos Aires, Argentina, June 14, 2011.
} 
governmental subsidies. Finally, the Ministry of Planning also governs the stateowned enterprises such as the nationalized oil company YPF.

The planning body in Argentina shifted dramatically over the past two decades. Under the umbrella of neoliberal economic reforms initiated by President Menen and the resilient economic crisis the agency was reduced to a marginal, almost inexistent role, completely overpowered by the Ministry of Economy. Subsequently with the return of left-Peronist governments and its effort to renew state intervention in the economy, the idea of economic planning took life again in the form of a new a powerful planning Ministry. The empirical accounts provide evidence that the causal mechanism predicted by the task specific institutional perspective, whereby transformations are expected in response to changes in the economic model operated consistently in this period. For the other theoretical approaches there is no consistent evidence that the causal mechanisms were in place and operated as expected.

\subsection{Conclusion}

Historical accounts of the creation and evolution of the planning agency in Argentina provide evidence of the operation of various parts of the causal mechanisms of institutional change hypothesized. Particularly and matching the environmental perspective, there is empirical evidence of the role played by international organizations through their diffusion instruments (international advisors, foreign missions, technical assistance, etc) in the creation and consolidation of the planning body. However, it would be inaccurate to think that internal actors were merely passive recipients of international interests. Quite contrary, another part of a causal mechanism in tune with the structuralinstrumental approach which operated as expected throughout the agency's history was its instrumental use for political purposes. Although evidence does not show the existence of coalitions built around the agency, data does provide indications that the agency was used by the President as an instrument to pursue different ends (e.g Frondizi used the agency to counterweight the power of Minister Alsogaray; Onganía to justify the military government; Alfonsin to appoint his close political affiliates from the Radical Party). With the exception of the 1966-1970 golden period of the organization, accounts do not provide support to the idea that the continuous changes in the organization responded to functional adaptations. Evidence is also weak to claim that transformations of the agency amidst fluctuations between democratic and military regimes were real departures from the preceding institutional trajectory. The common factor across fifty years of history of the planning body is the President's influence in each succeeding organizational change. 


\section{Chapter 6: Ecuador case study}

\subsection{The genesis and evolution of the planning agency}

Unlike other countries in the region that adopted the Import Substitution Industrialization model of growth during the 1930s, Ecuador continued with an export-oriented growth model until the 1950s. This can be explained by two factors: on the one hand, Ecuador was essentially a rural and agricultural country until the late-1960s, with agriculture employing almost $60 \%$ of the working population, as opposed to $14 \%$ in manufacturing; on the other hand, Ecuador did not have a large population or income level to support the development of consumer markets for locally produced goods (Pyne, 1975).

During this export-oriented period, the Ecuadorian economy was largely dependent on agricultural products, especially cacao, coffee and bananas, which accounted for almost ninety percent of total exports, exposing the domestic economy to the price volatility of these goods. However, in comparison with other Latin American countries, Ecuador experienced higher economic growth rates throughout this period, enjoying a relative political and economic stability since the 1940s (Larrea and North, 1997).

The trade cycle of these products determined the economic agricultural specialization of the two most important regions of the country, namely the coast and the highlands. The coast was primarily directed toward export production, while the highland was mainly organized around the production of domestically consumed goods (Grindle and Thoumi, 1993). During the course of the export boom, a powerful agro-financial oligarchy was formed in the coast, comprising bankers, export and import enterprises and producers. Meanwhile, the traditional highland elites kept the domain over social status, political power, government patronage and the military. According to Grindle and Thoumi (1993), economic and political rivalry between the two regions became institutionalized in the identities and reputation of their dominant urban areas of Quito in the highland and Guayaquil at the coast. As the coastal region increased its economic power, it also demanded a greater share of political influence.

By the mid-1950s, the high dependence on few crops, coupled with declining terms of trade for agricultural products, started to cripple Ecuador's economy. The export prices of raw materials declined relative to prices of manufactured imports, forcing Ecuador to rely on foreign loans to finance imports and development programs. In reaction to declining export revenues and following ECLA's recommendations, the state began slowly moving towards import substitution industrialization (Kofas, 2001). 
This strategy required an active state involvement in economic development, mainly through the planning and promotion of public investments in strategic sectors. For instance, the government constructed roads and ports, supplied technical assistance and credit to producers to facilitate the incorporation of new land for the production of bananas. In this context, the liberal government of Galo Plaza Lasso (1948-1952) received an ECLA mission that carried out a diagnosis about the Ecuadorian economy and its public administration. One of the main findings was the absolute absence of economic data for economic policy making, as well as the inexistence of adequate public organizations in charge of handling this data and promoting economic development (Vega, 1979).

Following the recommendations suggested by ECLA's report, The Economic Development of Ecuador, and advised by the International Bank for Reconstruction and Development-IBRD (World Bank), the government of President José Maria Velasco (1952-1956) continued with the program of institutional reorganization started by Galo Plaza's government. This program involved the creation of a series of public organizations involved in promoting and coordinating economic development. In this sense, the Industrial Development Center of Ecuador, the Ecuadorian Institute of Electrification, the National Security Commission and the National Board of Economic Planning and Coordination were established throughout Velasco's government. According to Martin-Mayoral (2009), the support and policy economic decisions provided by these agencies allowed a steep increase in industrial investment, which rose from 15.6 million sucres between 1953 and 1957 to 867 million between 1969 and 1972. For instance, with the coordinated work from these agencies, the government was able to invest in infrastructure development, especially in the creation of roads, such as the QuitoGuayaquil development axis, resulting in increased exports (Martín-Mayoral, 2009).

\subsection{National Board of Economic Planning and Coordination}

The National Board of Economic Planning and Coordination (JUNAPLA) was created by Emergency Decree Law $\mathrm{N}^{\circ} 19$ of 1954, following the recommendations suggested by ECLA's report The Economic Development of Ecuador. The board was structured as a collegial body integrated by the Ministries of Economy, Public Works and Treasury, the manager directors of the Central Bank and the National Development Bank, a representative of the National Economic Council and three citizens appointed by the President of the Republic, with recognized experience in public and economic issues. The chairman (executive director) of the National Board of Economic Planning was selected from one of the three members appointed by the President of the Republic (Salgado, 1979). 
During its first meeting, the board members approved the structural arrangement of the planning body. The agency was organized around two departments, a technical and an administrative one. The technical department was in charge of economic studies and forecasts with five subdivisions: agriculture and colonization; industry and energy; transport and communications; social wellbeing; and statistics. On the other hand, the administrative department was set up as the bridge between the technical department and the rest of the Ecuadorian public sector, as well as with the international financial institutions (Junta Nacional de Planificación y Coordinación Económica, 1954). Within the overall state structure, the National Board of Economic Planning and Coordination was under the hierarchy of the Ministry of Economy (Vega, 1971).

The new agency had an enormous demand for qualified technical personnel, which at the time was scarce in the Ecuadorian public sector. The government asked for the assistance of the International Bank for Reconstruction and Development, ECLA and the United States Foreign Operations Administration, as well as the Ecuadorian Central Bank. Many foreign technical personnel started to work in the agency, along with native professionals from the Central Bank and the National Development Bank (Junta Nacional de Planificación y Coordinación Económica, 1954).

In addition to supplying qualified personnel to the planning agency, the IBRD and ECLA sent David Gordon and Celso Furtado ${ }^{65}$ to Ecuador. Both officials worked together with the members of the board in defining the tasks that the agency was to follow. The planning body was granted with the mission of formulating the national and regional development plans, coordinating the economic policy making and public investment and advising the President of the Republic on all issues related to economic development (Junta Nacional de Planificación y Coordinación Económica, 1954). Specifically, the board was responsible for:

- Developing comprehensive projects aimed at promoting economic development

- Coordinating investment plans

- Providing advice on public expenditure prioritization

- Advising on ways to finance development plans

\footnotetext{
${ }^{65}$ Celso Furtado was a Brazilian economist whom, along with Raúl Prebisch, was one of the main formulators of economic structuralism, an economics school that sought to stimulate economic development through governmental intervention, largely inspired on the views of John Maynard Keynes. Furtado was Minister of Planning during the government of President Joao Goulart (1961-1964). Furtado was also one of the founders of the United Nations Conference on Trade and Development (UNCTAD) in 1964.
} 
- Collaborating with the Monetary Board in the identification and coordination of monetary policy

- Making fiscal policy recommendations

- Providing recommendations in the field of administrative, credit, foreign exchange and social welfare policies ${ }^{66}$

Inherent to its purpose, the National Board of Economic Planning and Coordination was responsible for collecting the economic data necessary to design a strategy to implement an import substitution industrialization model in Ecuador.

In my opinion, the largest contribution of JUNAPLA at that time was to begin producing economic data for the country. The government needed information, the President needed information and that was the initial purpose of JUNAPLA. JUNAPLA was the right hand of the executive. Another big success of JUNAPLA was the qualification of the public sector (...) All of that was done with the support and promotion of the international cooperation. ${ }^{6}$

According to Moncada-Sanchez (1974), the goal of generating economic growth through expanding exports and substituting imports with local industrialization had a widespread social consensus, with both coastal and highland elites agreeing with the adoption of economic planning and an inward-oriented growth model. The government, through the National Board of Economic Planning and Coordination, taking advantage of this consensus, subsequently started to construct its economic policy relying on foreign loans and foreign capital investment, a more efficient exploitation of Ecuador's natural resources and import substitution industrialization (Kofas, 2001).

By the mid-1950s, import-substitution had contributed to rapid urban growth, especially in the city of Guayaquil, the emergence of a new industrial and commercial working class and the overall expansion of a middle class. However, by the end of the 1950s foreign debt payments had rapidly risen and the budgetary deficit had increased. President Velasco Ibarra was followed by Camilo Ponce Enriquez (1956-1960), who reduced investment on public works programs and relied on more loans in an effort to contain the budgetary deficit. These policies were rejected by trade unions, which staged numerous protests and strikes. In 1959, police violently confronted rioters, resulting in several people being killed and many wounded (Kofas, 2001). The businesses from the coast region also disagreed with Ponce's economic policy, especially that of borrowing as a vehicle

${ }^{66}$ Emergency Decree Law 19, May 28, 1954

${ }^{67}$ Author's interview, former JUNAPLA official, Quito, Ecuador, May 29, 2012. 
for rapid development ${ }^{68}$, as well as the intrusive role in the state through taxes and tariffs.

Amid social strife, José María Velasco Ibarra won the presidential election of 1960, for the fourth non-consecutive time. Inspired by the Argentinean policies of President Arturo Frondizi, Velasco wanted to pursue a developmental reform model in Ecuador. Promising to improve living standards for workers and peasants, cutting taxes and conducting a land reform, Velasco used a nationalistic rhetoric that, together with the accusations of the former Government being proAmerican and too closely associated with the United Fruit Company ${ }^{69}$, allowed Velasco to attract diverse segments of the society, ranging from wealthy conservatives to indigenous people (Kofas, 2001).

Soon after coming into power, Velasco realized that the country's economic situation required the undertaking of unpopular measures that could quickly erode his political support. He took hold of two opportunities to confront this situation. First, the 1945 Political Constitution granted the President with almost unlimited possibilities to issue emergency decrees, which Velasco used to create new cabinet organizations and several public enterprises ${ }^{70}$ that helped him to fulfill numerous bureaucratic demands from his political supporters. Moreover, the President found that the United States' cooperation policy for Latin America (Alliance for Progress) allowed the government to access some resources that would help Velasco meet some of the electoral promises. However, this implied that Velasco had to tone down his anti-American discourse, which resulted in the antipathy of some of his voters (Pyne, 1977).

Velasco's effort to increase the number of bureaucratic positions at his will continued with the revocation of the Administrative Career Law, created during the previous administration (1956-60) with the intention of establishing a professional bureaucracy, dismissing hundreds of government employees and replacing them by Velasquistas (Pyne, 1977). The bureaucratic instability was also reflected in the high turn-over of the presidential cabinet. Between September 1960 and November 1961, the cabinet, composed of 10 ministers, experienced 28 changes. These changes not only reflected the complexion of the shifting coalition of political forces supporting the government, but also it indicated that the

\footnotetext{
68 The Ecuadorian external public debt was US\$110 million by 1960.

${ }^{69}$ The United Fruit Company was an American corporation that traded in tropical fruit (primarily bananas) grown on Central and South American plantations and sold in the United States and Europe.

70 During the fourth administration of Velasco 122 executive decrees and forty-five emergency decree laws were issued.
} 
President regarded his ministers as disposable. If a political crisis arose, Velasco was prepared to use his ministers as scapegoats (Pyne, 1977). As a result, the limited continuity of policy implementation was a constant during this period.

Amidst this avalanche of reforms that deinstitutionalized the public sector, President Velasco strengthened the structural arrangement of the National Board of Economic Planning and Coordination in several ways. First, Velasco appointed the director of the planning agency as a board member of all major economic policy bodies and public enterprises, such as the External Finance Committee, the Technical Committee of National Budget, the National Security Commission, the Committee of Industrial Development, the Agricultural Development Committee and the Higher Council of Trade. Second, Velasco transferred the organization from the Ministry of Economy to the Presidency of the Republic, elevating its hierarchy as a direct advisor to the President. Third, Velasco ordered the creation of planning offices inside all sectoral ministries in order to contribute with the National Board of Economic Planning and Coordination in the preparation of plans and budgets. Fourth, Velasco assigned the board with the task of preparing a national development plan, named the Immediate Development Plan (Salvador, 1979). Finally, contrary to the clientelistic bureaucratic placements that Velasco carried out in other agencies, he kept the National Board of Economic Planning and Coordination staffed with technical personnel (Vega, 1971).

This apparent contradiction of fortifying the planning agency makes sense. First, having a planning agency was one of the requirements set by the Alliance of Progress. Eliminating the agency or using it as a patronage strategy meant risking the aid from the United States. Second, since its inception in 1954, the planning agency started to be staffed by personnel trained by ECLA and the World Bank; again, using the agency for clientelist staffing meant losing the most qualified people in the Ecuadorian public sector. Third, Velasco was able to disguise questionable political decisions in the framework of the national development plan, which gave him the "technical" justification. Finally, by appointing the director of the planning agency as a board member of all major economic policy bodies and other agencies, President Velasco found a way to directly control the policy decision making in these organizations (Vega, 1971).

After one year in power, a steady decline in the export market caused by the crisis in the banana sector left Velasco without resources to continue financing the import substitution industrialization through government subsidies. Additionally, per capita income began to fall and inflation increased. In an effort to preserve the state's financial solvency, Velasco's government, by presidential decree, resorted to new taxes, which led to social unrest (Pyne, 1977). From October to November 
1961, a wave of protests and strikes led by the Trade Union Confederation practically paralyzed the country. The economic situation finally forced Velasco to devalue $^{71}$ the sucre by 20 per cent and impose a large number of additional consumer taxes (Pyne, 1977). This decision placed Velasco in a bitter conflict with Congress, especially with President of the senate Carlos Julio Arosemena, who was also the Vice-President of Ecuador and a representative of the importing and landowners sectors of the oligarchy. According to Pyne (1975), the implementation of such a program held little appeal for the members of a small yet powerful oligarchy, virtually exempted from taxation. The failure of government in the economic field eventually dried up Velasco's support in Congress, as well as from virtually all sectors of society. On November 9, 1961, Congress, supported by the military, declared vacant the Presidency and appointed Carlos Julio Arosemena Monroy (1961-1963) as a temporary replacement. Arosemena lasted less than two years in power, being deposed by the military in July 1963, who considered him too close to the Cuban revolution.

The military government (1963-1966) justified its intervention on the grounds that it was necessary to bring to an end the institutional chaos brought by Velasco and Arosemena, as well as promoting a new socioeconomic structure that would permit the state to comply with its functions. The military were embracing a modern vision of the state and capitalism promoted by the United States through the Alliance for Progress. Financed with U\$ 84.5 million of US aid, the military government started a structural reform in 1964, concentrated in two areas: the creation of a new tax system and land reform (Lauderbaugh, 2012).

To carry out this structural reform, the military government required basic data (socioeconomic and demographic) as well as the organizational capacity to plan and manage the reform. In the National Board of Economic Planning and Coordination (the only agency that had not been patronized), the military junta found the adequate instrument for this purpose. The planning body was made responsible for writing and directing the First General Plan of Economic and Social Development for the Period 1963-1973, in which the basic policies for land and tax reform were established (Vicuña, 1987). Regarding this plan, a former member of JUNAPLA expressed:

\footnotetext{
${ }^{71}$ According to Pyne (1975), even though the exporting class, centered on Guayaquil, should favor devaluation as the main solution of the economic crisis at the early stage, at the moment when the decision was taken the policy failed to bring any immediate advantage. On the other hand, the importers and landowners from Quito opposed devaluation on the grounds that it would push up their costs.
} 
The plan made by the military was a very detailed one, clearly based on the industrialization ideology of the Military Government, and highly influenced by experts from the Alliance for Progress, especially in the idea of the land reform. Remember that Americans were very afraid that the Cuban revolution spread in Latin America. However, after the fall of the Military Government many of the things that the plan stated were abandoned. ${ }^{72}$

In terms of land reform, the plan recommended issuing an agrarian Law to break up large land estates in the highlands and redistribute them to agricultural labors. Moreover, the plan suggested finishing the huasipungo labor system, which relegated indigenous agricultural labors to a type of medieval serfdom (Lauderbaugh, 2012). The military junta officially launched the agrarian reform by decree 1480 of 1964 . With this act, all responsibility was vested in the Instituto Ecuatoriano de Reforma Agraria y Colonización-IERAC (Martz, 1972).

The military in Ecuador were the first ones to propose an agrarian reform, of course an agrarian reform tailored to their interests; information from JUNAPLA was essential for the military and all of that was built into a plan. ${ }^{73}$

Regarding the tax reform, the plan sought to modernize the country's tax system, which had hitherto heavily relied on indirect taxes and lacked an efficient collection method (Kofas, 2001). The development plan recommended the merging of some disperse taxes and the abolishment of other minor ones (Vicuña, 1987).

Besides responsibility over the government's two main structural reforms, the instrumental importance and confidence given to the planning board by the military government was reflected in the additional tasks that it assigned to the agency. The planning board was made responsible for coordinating international technical assistance, advising the public sector on issues related with external financing, regulating the issuance of state bonds; ruling over municipal budgets and other public sector bodies and keeping a database in which national and international consulting companies were registered (Moncada, 1974). The range of tasks granted to the planning body reflects how the agency had become one of the few reliable and capable organizations among the public sector.

\footnotetext{
72 Author's interview, former JUNAPLA member. Quito, Ecuador, May 31, 2012

${ }^{73}$ Author's interview, Subsecretary of General Planning-SENPLADES. Quito, Ecuador, May 31, 2012.
} 
In line with the recommendations made by the International Monetary Fund and World Bank, the military junta adopted austerity measures to reduce expenditures, lower subsidies, raise gasoline taxes and increase consumer taxes. However, the government continued to rely on foreign loans as a way of financing its import substitution industrialization programs. During the first year of the military regime, external public debt rose from US\$116 million in 1963 to US\$163 million in December 1964 (Kofas, 2001). Business interests from both Guayaquil and Quito started to oppose the regime due to the austerity measures.

By 1966, the revenues from banana exports had again significantly reduced, foreign debt kept rising, government revenues were diminished, the economy was showing signs of recession and there was increasing social pressure on the military junta to abandon the IMF and World Bank austerity measures. Demonstrations orchestrated by the chambers of commerce of Guayaquil and Quito, including a national general strike with workers, students and other political anti-junta interests took place, demanding a return to civilian government (Lauderbaugh, 2012). On March 30, 1966, popular opposition and strikes forced the junta to yield power to an interim coalition government headed by Clemente Yerovi, who had served as a director of the planning board during the military regime. In October 1966, a popularly elected constituent assembly drafted a new constitution and elected Otto Arosemena Gómez, a political centrist, to act as a second provisional President. The new constitution started to run by May 1967, with presidential elections held in June 1968.

From its inception in 1954 until the end of the military regime, the empirical accounts provide steady evidence that the planning body in Ecuador was shaped by the influence of external actors, especially ECLA, the Alliance for Progress and the IBRD. By various means such as conditionality loans, foreign missions, technical assistance and even staffing, powerful international actors subsequently determined the path of the organization through this period, matching the hypothesized causal mechanism of the environmental institutional approach. In line with the above, almost all development plans drafted by the agency reflected the policy priorities of these external actors, particularly regarding economic principles of import substitution industrialization and land reform. This influence marked the start of a trajectory that the agency kept across the years.

During this period, empirical data also support some of the elements of the causal mechanism derived from the structural-instrumental perspective. In particular there is a rational effort to use the planning body for a given purpose. For example, President Velasco in an effort to keep control over policy making preserved the technical autonomy of the agency and granted it additional power to oversee the 
large number of clientelistic agencies. In turn, the military regimes saw the agency as a "pocket of efficiency", with the information and technical capacities to deliver the land and tax reforms.

José María Velasco (1968-1972) was voted into the presidency for the fifth time. Paradoxically to his former view, President Velasco withdrew many of the tasks from the National Board of Economic Planning and Coordination that his government had previously assigned to the board in 1961. For instance, the board was no longer required to pre-approve the economic development policies of other ministries or provide advice on the formulation of the territorial governments' budgets. The government also abolished the seat of the planning Board in twenty agencies and commissions. The National Board of Economic Planning and Coordination prepared a five-volume document named the Ecuadorian Development 1970-1973, which contained a diagnosis of the Ecuadorian economy, as well as a list of investment projects and economic measures to be implemented. Given the lack of presidential support, the plan was never put into practice (Lauderbaugh, 2012). Moreover, during the same time the planning board prepared another document, the Development Strategy for Ecuador, laying the groundwork for undertaking economic measures to tighten control on foreign exchange transactions and raising import tariffs, which also had no executive backing (Moncada, 1974).

Given the shrinkage of duties, the planning board concentrated itself on evaluating the implementation of previous plans and working together with ILPES in developing a document entitled Basis for Development Strategy in the context of a SubRegional Integration (Salgado, 1979). The situation of the planning agency's relative inactivity incited many technicians to leave the organization. This event was so notable, that it was registered in the published memoirs to commemorate the agency's $25^{\text {th }}$ anniversary in 1979.

This change of direction of President Velasco vis-a-vis the planning body is possibly explained by both, the economic conditions prevailing after 1968 and the structure of the public administration that Velasco inherited from the military regime. By that year, rampant inflation, high foreign debt, falling exports and budget deficit made it impossible to continue with the government's public investment program. The deterioration of the fiscal situation forced Velasco to concentrate on short run measures led by the Central Bank and the monetary junta, to the detriment of long-term planning. The President needed to take rapid and effective short-term policies to confront the crisis, which conflicted with the process of revision, approval and prioritization of ministries' policies of which the planning board was in charge. 
On the other hand, by the end of the 1960s Ecuador was plagued by 700 semiautonomous public agencies that had been put in place both during Velasco's previous presidential term and by the military junta. This proliferation of agencies caused excessive budgetary pressures and confronted a large overlap of planning functions (Kofas, 2001). Many of such agencies not only had functions related to sectoral planning, duplicating the role of the planning body, but also had a board of directors in which the cabinet ministers had minor representation, thus granting Velasco little or no control over these agencies. In addition, the 1966 Constitution had allowed greater interference of Congress in public policy and its administration (Martz, 1972).

Finally, one further factor that elucidated the diminishing importance of the planning agency in this period was the fact that the Alliance for Progress aid program was due to end by the end of the 1960s, thus reducing the pressure to keep the former status of the agency.

During the early-1970s, President Velasco advocated for a return to the 1945 Constitution that granted him more powers to legislate and implement public policy. Moreover, the President pressed for public organizational revision in which the directorate of the semi-autonomous public agencies was reconstituted with the majority of its members as government appointees (Martz, 1972). By June 1970, President Velasco declared the adoption of a revised version of the 1945 constitution by executive decree, closed Congress, abolished half of the public organizations, shuttered universities and declared an auto coup d'état. Velasco was able to retain power until February 15, 1972, when once more he was ousted by the militaries (Martz, 1972).

The new military junta (1972-1979) in midst of a boom of oil revenues ${ }^{74}$ promoted a nationalistic economic policy by keeping taxes low, heavily subsidizing fuel and food, expanding public-sector employment and increasing government-sponsored welfare benefits. The military government also assumed broad tasks, moving into banking, basic industries, fishing, agriculture, cement and petroleum by establishing more than a dozen new public enterprises, including the Ecuadorian State Petroleum Corporation-CEPE (Martz, 1988). State participation in mixed enterprises was also encouraged, expanding the economic functions of the Ecuadorian state beyond those accomplished by any previous government. Consequently, government expenditure increased faster than revenues, despite the

\footnotetext{
${ }^{74}$ In 1967, a large oil field were discovered in the Amazon jungle. According to Grindle and Thoumi (1993), the Ecuadorian oil output was 1.4 million barrels in 1970, 1.8 million in 1971, 28.6 million in 1972, and 76.2 million in 1973. The income generated by the oil boom was larger than the generated by the banana, cacao and coffee booms of the past.
} 
large increase in oil revenues. The external debt also grew, from U\$241.5 million in 1970 to U\$ 512.7 million in 1975 and U\$ 6185.8 million in 1981 (Grindle and Thoumi, 1993).

Planning had much appeal within the military dictatorship, there is this vision that I think is almost inherent to the armed forces of the importance of planning. Dictatorships in Ecuador were very nationalistic and even progressive. And this coincided with the boom in oil production (...). At this point JUNAPLA plays an important role, not only in terms of planning for the country's development but contributing to consolidate industry and the national institutional setting, and all of that was put into a development plan. ${ }^{75}$

All these changes were taking place in the context of a military government that lacked programmatic unity on issues other than nationalism (Martz, 1988). The National Board of Economic Planning and Coordination fulfilled this gap by means of providing the military junta an institutionalized organization to give content to the revolutionary and nationalist government. As a result, the military government launched the Comprehensive Plan for Transformation and Development 1973 - 1977. According to Santos (1979), this plan was the result of a precise definition of a political program to address a philosophy and action plan for a revolutionary nationalistic government.

Once again, the military regime brought many of the functions that had been withdrawn during the 1970 reform back to the planning body, as well as positioning the executive director of the planning board in the council of all major economic policy bodies and public enterprises.

When the military came into power, they found in JUNAPLA a reliable source of information for decision making. The military once again elevated the importance of JUNAPLA and introduced back to the agency the functions it had had earlier during the sixties. ${ }^{76}$

However, shortly after, the Ecuadorian economy again started to show signs of recession due to the stagnation of international oil prices, upon which the country depended. By the end of the 1970s, the regime could not reconcile the conflicting interests of the coastal and highland regions, namely the discrepancies between

\footnotetext{
${ }^{75}$ Author's interview, former JUNAPLA official, Quito, Ecuador, May 25, 2012.

76 Author's interview, former JUNAPLA, CONADE, ODEPLAN, and SENPLADES official, Quito, May 28, 2012.
} 
outward-oriented agro-exporters from the coast and import-dependent industrialists from the highland (Grindle and Thoumi, 1993). With rising political and social opposition, increasing economic troubles and internal disputes among the Ecuadorean military, the government reluctantly negotiated a three-year retreat in 1976, which led to the approval of a new constitution in 1978 and elections in 1979, whereby Ecuador returned to democratic rule.

The learning of the organization and trajectory adopted over its early years becomes self-enforced and path dependent during the period between 1968 and 1979. President Velasco disdained the agency and reduced its powers while the military regime that followed, once again treasured the agency to pursue its nationalistic policy. Regardless of its shifting preeminence within the public sector, the agency continued doing development plans of various types (national, sectoral, regional), all of them heavily influenced by the original seal of ECLA. This institutional pattern will continue over the coming years.

\subsection{National Development Council-CONADE}

As part of a strong presidential system and model of development based on state intervention, the new constitution of 1978 situated economic planning at the center of all government policies. The National Board of Economic Planning and Coordination was transformed into the National Development Council-CONADE. The constitution converted the National Development Plan and sectoral plans as mandatory for the public sector and indicative for the private sector. Whereas the development plans previously required approval at the Senate, the Constitution of 1978 established that these plans only required Presidential approval.

This action sought not only to delete a process that in the past had had no effect, but to give more freedom to the President to decide on development policies. ${ }^{77}$

The constitution also defined that the Vice-President of the Republic was to chair the new planning council, which in addition was composed by ten members: four ministers of state, appointed by the President; the President of the Monetary Board; a delegate of Congress; a representative of the mayors and provincial prefects; a spokesperson from the organized labor; a representative of commercial associations; and a person representing the technical universities and schools.

\footnotetext{
77 Author's interview, former JUNAPLA, CONADE, ODEPLAN, and SENPLADES official, Quito, May 28, 2012.
} 
Despite the high positioning that the 1978 constitution granted to central planning, CONADE over the 1980s and 1990s never attained the expected supremacy, but quite contrary lost much of its importance within the Ecuadorian public sector and its appeal for the President. The events that follow help explain this situation.

First, in 1982 the Latin American debt crisis hit Ecuador particularly hard due to its high dependence on external revenues, forcing the Ecuadorian governments throughout the early 1980s to undertake structural adjustment policies to attain fiscal balance. Governments from both center-left and center-right, privileged monetary stabilization and financial liberalization policies over industrial promotion or economic planning policies. As a result, the decision making centers of the economic policy shifted away from organizations such as CONADE to the Central Bank and the Ministry of Finance (Montúfar, 2000). The powers of CONADE in economic matters were gradually dismantled; for instance, the national development plans prepared by CONADE were no longer mandatory for all public sector organizations, while similarly, projects to be financed by international resources no longer required pre-approval by CONADE. At this point, the President attained direct powers to amend the National Development Plan regardless of CONADE's position. These changes deeply altered the prevalence of planning in the hierarchy of state functions and economic planning began to lose relevance in Ecuador (Montúfar, 2000).

Second, the import substitution industrialization development model dried up and was replaced by the world's dominant paradigm, a model focused on liberalizing markets, privatizations and shrinkage of the state which heavily contrasted with the traditional statist profile that the planning agency had had. Multilateral agencies such as the World Bank were advocating for rolling back the state and associated state intervention in the economy through economic planning with inefficiency and resource misallocation. A reflection of this position is expressed by Vice-President and Director of CONADE and former Ministry of finance, Alberto Dahik, who stated that the planning body was a constitutional organization that was not in tune with the country's economic and social realities. According to the Vice-President, economic planning in Ecuador had been developed under the influence of a statist ideological scheme, which saw the engine of development in the state. Following Dahik, this approach to planning needed to be changed to adapt it to the market, as well as the social and political realities of Ecuador. ${ }^{78}$

Third, given that the responsibility over planning had been assigned by the 1978 constitution to the Vice-President, the planning agency was pushed aside from

${ }^{78}$ El Comercio “El CONADE un Nuevo Ministerio?” June 1, 1994. 
direct control by the President. This made the agency lose political appeal for the President, as it no longer helped him to pursue his own interests.

What happened was that in the attempt to give planning a larger political weigh it was handed out to the vice-President, but it actually resulted in the complete opposite. In Ecuador, traditionally the vice-President, has been a political rival of the President, on occasions even a conspirer against the President. So it is not uncommon for the President to try to minimize the responsibilities granted to the vicePresident, to avoid possible conspiracies. So, basically in this context, planning was blurred. President was not going to delegate decisions over economic development in someone he did not trust. And well, during the 80 s the economic problems called for immediate decisions and little planning. ${ }^{79}$

By the early-1990s, this idea was shared by most of the former Presidents and secretaries of the JUNAPLA and CONADE respectively, who gathered in a forum entitled Reality and Perspective of Planning in Ecuador ${ }^{80}$. Conclusions converged towards the statement that the withdrawal of planning from economic decisions resulted from both the location of the planning agency within the state's structure and the concern for the short-term measures due to the economic problems. In this context, a former secretary of CONADE stated:

At that time, CONADE had a marginal role in economic policy and in the important decisions of government. Even though we tried contributing to the debate, our tie to the vice-presidency put us off the President's radar. Besides, the doctrine prevailing was to allow markets to work freely, and well we did not fit very well into that. ${ }^{81}$

In early 1992, President Borja (1988-1992) and the then secretary of planning Moisés Tacle intended to pass a reform to transfer back the head of the planning body from the Vice-President to the President, with the aim of lifting again the political support to the agency and providing the President of the Republic with an economic expert body capable of advising him on such matters. In an interview with the Ecuadorian diary Hoy, Moisés Tacle expressed:

\footnotetext{
79 Author's interview, former JUNAPLA, CONADE, ODEPLAN, and SENPLADES official, Quito, May 28, 2012

80 See Hoy, “La Planificación en Otro Rumbo," September 30, 1991 and Hoy, “Ausencia de Políticas Afectan a Planificación." October 10, 1991.

${ }^{81}$ Interview with former secretary of CONADE, Guayaquil, May 21, 2012.
} 
Well, what advantages would bring that the President of the Republic chairs CONADE? You know that the traditional criticism to CONADE has been that planning in the country is a kind of dead book that is not followed by the government. We believe that if the President of the Republic presides over the actions of the planning agency, this will contribute to a stronger enforcement of the actions laid out by the National Development Plan. ${ }^{82}$

However, this initiative did not prosper because it required a constitutional reform that was not easy to carry out in the few months that President Borja had left in power. ${ }^{83}$ "That's the biggest problem because unfortunately all you have to do with the planning agency is not even product of a law but the constitution itself" ${ }^{84}$

President Duran Ballen (1992-1996) implemented a significant number of neoliberal policies, including reducing public expenditures, cutting subsidies, as well as decentralizing and privatizing state owned industries. From 1993 to 1995, eleven state-owned companies were privatized. ${ }^{85}$ In addition, the government passed the Capital Markets Law to promote foreign investment liberalization, as well as the Hydrocarbons Law, which opened petroleum investment to private investors (Hey and Klak, 1999). Ecuador withdrew from OPEC in 1992, in a move that freed the country from its $\$ 2$ million annual membership fee, as well as production quotas. All these reforms required the strengthening of the Ministry of Finance to the detriment of the planning agency. In fact, under the rubric of modernization of the state, the government established the National Council of Modernization, agency, which, along with the Ministry of Finance, guided the implementation of the promarket and modernization of the state policies. This modernization of public administration was understood by the government as the dismantling of the state capacities of guidance, planning, regulation, control and redistribution. ${ }^{86}$ According to a former CONADE official the effect on the agency was the following:

\footnotetext{
82 Hoy “Borja Presidira el CONADE”. March 2, 1992.

${ }^{83}$ Interview with Moises Tacle. Cited in El Comercio (1994) "El CONADE un Nuevo Ministerio?" Quito: June 1, P 2-A.

${ }^{84}$ Interview with Moises Tacle.Cited in El Comercio (1994) “El CONADE un Nuevo Ministerio?" Quito: June 1, P 2-A.

${ }^{85}$ Crisis Group (2007) Ecuador: Overcoming Instability? Latin America Report: N`22 - 7.

${ }^{86}$ Base on Author's interview, Subsecretary of General Planning-SENPLADES. Quito, May 31, 2012.
} 
CONADE experienced a strong institutional weakening; of about 400 staff members in 1994, we became 40 when the organization was transformed into National Planning Office. During that period we worked poorly on issues of decentralization and regional planning. ${ }^{87}$

By 1996, the state had surrendered much of its regulatory power, while foreign capital accounted for an extraordinary amount of domestic economic activity. The neoliberal reforms caused animosity among social groups, including highly organized indigenous communities, unions and peasants, which contributed to the political instability that the country experienced until 2007.

In correspondence with the cultural-environmental perspective, empirical accounts show that amidst a general fading of the planning agency along these years, CONADE nevertheless continued its path dependent trajectory drafting development plans, in the same fashion that it had done in the past. Regarding the hypothesized causal mechanism of the task-specific perspective, there is no empirical evidence in this period to support that CONADE adapted to changes in the prevailing environment. On the contrary, despite the shift in the economic paradigm the agency did not adapt any of its functions to respond to the tasks demanded by an open-market economy. This period also provided some evidence related to the politics of the agency design. Tuned with the structural-instrumental perspective, there was an attempt to protect the agency by giving it Constitutional status, thus elevating the transaction costs in transforming the agency. In theory, this elevated status should have empowered the role of the planning body. However the empirical accounts coincide in that the weakening of CONADE over this period was also fueled by the hierarchical positioning of the agency under the Vice-President which conflicted with the President's control of the agency.

\subsection{National Planning Office-ODEPLAN}

In 1998, Ecuador adopted a new Constitution. According to Mejía et.al (2007), the new Constitution was inspired by the need to strengthen political institutions that promoted governability and improved political representation. However, in practice, the approved reforms strengthened presidential powers over Congress, and especially those related to the budgetary process. The constitution not only granted the President with the exclusive right to initiate the budgetary process, but also made him less dependent on gathering legislative support for budget approval (Mejía et.al, 2007).

87 Author's interview, Former official of CONADE, ODEPLAN and SENPLADES. Quito, May 29, 2012. 
In this context, the 1998 Constitution settled the planning body as a budgetary institution responsible for setting the national targets for economic and social development, fixing the short-, medium- and long-term development goals to be achieved in a decentralized manner and providing guidance for public investment. To comply with this constitutional provision, the government created, by Executive Decree 120 of September 10, 1998, the National Planning OfficeODEPLAN, replacing the National Planning Council-CONADE. The new planning agency directly depended on the Presidency.

This was a period of both political and economic instability for Ecuador. Six different Presidents took office between 1997 and 2000 amid strong popular protests and legislative-executive inter-branch conflicts. By the year 2000, inflation rate was at $78 \%$, the highest rate in 32 years and the internal gross product was down by $7.5 \%$, while unemployment was peaking at $17 \% .88$ The government responded to the crisis by dollarizing the economy in 2000. Ecuadorian policymakers shifted their attention towards adopting reforms to secure a responsible fiscal management. Accordingly, the Ministry of Economy and Finance prevailed over the planning agency during this period.

\subsection{National Secretary of Planning and Development-SENPLADES}

In 2004, the government of Lucio Gutierrez (2003-2005) transformed ODEPLAN into the National Secretariat of Planning and Development-SENPLADES, by Executive Decree 1372, providing it the same rank as the Ministry of State, responsible for national planning. Among others, SENPLADES was assigned with the following functions: (i) the formulation and revision of long-term, mediumterm and annual national development plans, including the combination and alignment of sector and subsector programs in these plans; (ii) periodic reporting and evaluation on the progress of development plans; (iii) negotiating the acquisition and coordination of foreign aid or credit; and (iv) participation in the budgetary process by targeting public investment.

On January 15, 2007, Rafael Correa (2007- present), a left-leaning economist campaigning against the neoliberal economic policies, won the presidential elections. Correa's government centered its efforts on reasserting the state's control over Ecuador's economy, especially through the creation of subsidies, monetary transfers, tariffs and by reducing the independence of the Central Bank. As a part of this process, President Correa highlighted the urgency to enhance and

\footnotetext{
${ }^{88}$ El desempeño económico en dolarización (2012, December 31) El Telégrafo. Retrieved from http://www.telegrafo.com.ec/economia/masqmenos/item/el-desempeno-economico-endolarizacion.html
} 
strengthen the role of planning and SENPLADES. For his government, development planning is essential to organize and coordinate the public sector, rescue the efficiency and legitimacy of the state and make possible the redistribution of wealth in the country. ${ }^{89}$ Accordingly, a new constitutional reform (2008) brought back economic planning as a compulsory function of the state.

The role of the National Secretariat of Planning and Development (Senplades) has been fundamental for breaking with the inertia of previous governments, in particular by prioritizing public investment. We have a new Constitution that defines the development scheme. We have a National Plan for Good Living, whose axis is sponsoring equality, cohesion and social integration and territorial diversity. ${ }^{90}$

Under Correa's administration, the role of SENPLADES was improved and the agency was merged, by executive decree 103 of 2007, with the National Council of State Modernization (CONAM). Furthermore, Correa created planning offices within the jurisdiction of each state ministry and secretaries. These bureaus have the duty of defining their own sectoral development targets and plans in coordination with SENPLADES. As part of a strategy to regain the state's role in regulation, planning and redistribution, Correa granted SENPLADES with the following new functions: (i) promoting the transformation of specialized public enterprises to reach a selective import substitution; (ii) coordinating with the various state institutions towards the compliance of the goals and objectives of the National Development Plan; and (iii) encouraging de-concentration and decentralization of public administration through the Under-Secretaries of Zonal Planning.

In recent years the planning body in Ecuador recovered its power, regaining control over functions that had faded while assuming new roles in state reform and social policy among others. This rebirth of the organization has been fueled by left-wing President Correa, who has a strong believe in state intervention, economic planning and participatory democracy, and thus purposefully strengthened SENPLADES as the organizational instrument to recover the axis of state guidance. Although with renewed functions, SENPLADES is still framed under the original seal impressed by ECLA, yet again evidencing a pathdependent trajectory.

\footnotetext{
${ }^{89} \mathrm{http}: / /$ www.senplades.gob.ec/web/18607/93

${ }^{90}$ Falconí, Fender (2011) “¿Por qué la SENPLADES?” El Telégrafo. Quito: noviembre
} 


\subsection{Conclusion}

The historical narrative of the creation and evolution of the planning agency in Ecuador permit identifying the causal mechanisms that in certain historical moments coincided with those hypothesized by the environmental and cultural theories of organizational change. Based on the data collected, there is evidence of the influence that international organizations like ECLA and the Alliance for Progress had on the construction, institutionalization and startup of the agency. This early influence over the planning body, especially in the core function of producing development plans heavily marked the subsequent trajectory of the organization in later years when the agency, amid varying political and economic atmospheres continued performing this same task, in what could be a manifestation of an institutional lock-in. However understanding institutional change only on the grounds of path dependency and isomorphism is not sufficient to explain the evolving role of the planning body. For example, why under historical moments that constituted critical junctures did not these events prompt the agency into a different trajectory? Or how does the institutional lock-in explain small and gradual transformations that subsequent governments introduced in the agency? Central to understanding the configuration and change of the planning agency throughout its 62 years of existence is the figure of the President and the capacity of this actor to change the agency's structure and functions. 


\section{Chapter 7: Chile case study}

\subsection{The genesis and evolution of the planning agency}

The collapse of the international economy during the great depression strongly hit the export-oriented Chilean economy. The drop in prices and sales of most of Chile's exports, mainly nitrate, brought a significant negative wealth effect (Lüders, 1998). ${ }^{91}$ This resulted in an immediate fiscal deficit, the suspension of debt payment and the failure of many Chilean businesses, with a corresponding increase in unemployment, poverty and social unrest.

This situation called for the abandonment of liberal economic development strategies based on an export-oriented model and advocated for the implementation of a new strategy based on state intervention. President Arturo Alessandri (1932-1938) provided the first steps in setting up Import Substitution Industrialization as a governmental policy (Silva, 2007). Alessandri raised import tariffs, established import quotas and controls over exchange rate and promoted the development of domestic manufacturing. The new development strategy required the support of a new sociopolitical multi-class coalition, which Alessandri found among incipient industrialists, financiers, merchants and even landowners. ${ }^{92}$ All of them believed in the necessity of expanding and stimulating the domestic industry as a means of reviving the economy and resuming positive growth rates.

Nurtured by Alessandri's ideas about economic policy, a group of left-wing political parties and social organizations that advocated for increased state intervention in the economy created a political coalition named the Popular Front. The Popular Front gathered together the Radical Party, the Socialist Party, the Communist Party, the Democratic Party and the Radical Socialist Party, as well as organizations such as the Chilean Confederation of Workers. The coalition won the presidential voting of 1938, with Pedro Aguirre Cerda (Radical Party) elected President for 1938-1941.

Aguirre Cerda continued to push forward the inward-oriented development strategy. According to Silva (2007, p. 73), "this period witnessed the establishment

\footnotetext{
${ }^{91}$ GDP per capital fell by $47 \%$ and exports by $79 \%$.

${ }_{92}$ At this early stage, Alessandri's industrial policy did not favor non-traditional basic industries discriminating agriculture. According to Silva (2007), landowners supported industrial policy because the 1930s was a period of high unemployment and social turmoil, and the agricultural sector was not ready to bring in unoccupied labor quickly enough. Additionally, Alessandri's industrial policy promoted industries that complemented the agricultural sector, rather than competing against it.
} 
of key elements of the import substitution industrialization model: the developmental state with the institutions and expertise to plan national economic and social strategies and with the instruments to implement them". During this period, the industrialization process received a vital impulse from the state through the creation of the Chilean Development Corporation (CORFO) in 1939. From its creation until the military coup in 1973, CORFO was the organizational axle of the industrialization process, and the main planning agency for economic development in the country (Silva, 1994).

\subsection{The Chilean Development Corporation-CORFO}

According to Silva (1994), enacting the law that created CORFO was preceded by a short yet intensive period of debate and negotiation in Congress, which revealed the different interests and fears between the government, the right wing parliamentary opposition and the entrepreneurial sector. The main stand against the creation of the agency came from representatives of the industrial sector, with some entrepreneurs worrying about the state assuming economic responsibilities related to the development of the business sector, without a proper representation of the business class in the new organization. Specifically, the entrepreneurial sector feared that the government would use CORFO to privilege the administration's interests and promote political activism. The creation of CORFO was also questioned by landowners from the agricultural and mining sectors, who under the preceding Alessandri's government had felt that traditional agricultural and mining prices had been made less competitive compared to imports. This sector feared the creation of a new governmental organization in charge of further promoting industrial development (Muñoz, 1977).

These fears became real attempts to undermine the agency's creation during the bill's transit through Congress. For instance, at some stage in the discussion at the Chamber of Deputies, opposition made changes in the bill, aimed at reducing the influence of the President in the agency. The new organization was made accountable to Congress, as it was compelled to inform Congress on its development activities; moreover, it was also put under the supervision of the General Comptroller of the Republic. In the same way, throughout the debate in the senate, the opposition required the bill to include a requirement for the agency to present each development project for the approval of Congress. In this way, the opposition was trying to obstruct government from having control over financial resources, and putting CORFO completely under the tutelage of Congress (Silva, 1994). Similarly, entrepreneurial organizations ${ }^{93}$ demanded the adoption of a

\footnotetext{
${ }_{93}$ The society for Industrial Development (SOFOFA) and the Corporation for Production and Commerce (COPROCO).
} 
representative formula in the selection of CORFO's board of directors, which would appoint the agency's director. According to Silva (1994), President Aguirre Cerda eventually used his presidential veto to reject many of the proposed modifications to the bill, limiting the efforts of the opposition party to weaken the autonomy of CORFO.

In addition, other scholars (Kaufman, 1972; Loveman, 1979; Silva, 1994) have stressed that the final Congress' acceptance of CORFO as an autonomous body was the output of a non-official agreement between government and the opposition concerning the issue of peasant unionization. Essentially, the opposition accepted the central role of CORFO in the country's industrial development, while the government committed to forbidding the unionization and penetration of urbanbased left wing parties into the countryside (Silva, 1994).

CORFO was finally created through Law 6.434 of 1939 as an executive agency, in which the Minister of Economic Affairs was the corporation's executive President and the executive Vice-President, appointed by the President of the Republic, the actual manager of the organization. The board of directors included representatives from the government, entrepreneurial organizations and a single representative of the Chilean Workers Confederation. Since its inception, CORFO acquired functions related to the formulation of a national production plan, establishing subsidies for targeted industries and setting up tariffs and differentiated exchange rates.

Given the nature of the functions assigned to CORFO, the agency was subject to different interests from external societal forces and stakeholders. To undermine this outside risk, President Aguirre Cerda decided to isolate the agency from external pressures by staffing it with highly specialized engineers. According to Silva (1994), the highly specialized expertise of CORFO's technocrats, who in turn controlled valuable technical information, was one factor in explaining their predominance over entrepreneurs and other government officials. The technocratization of the decision making of CORFO, by Aguirre Cerda, became openly or tacitly supported by important sectors of the population: 
Both public officials and industrialists interviewed by Cavarozzi were unanimous in their opinion about the high quality of CORFO's technical personnel. As he states: they agreed in pointing out that the institution had been able to attract technicians, who for the most part, surpassed the levels of professional expertise and performance of their colleagues in other public, and even in private business organizations. ${ }^{94}$

In this way, the ascendancy of technocrats in CORFO was experienced by many as a suitable way to recruit non-corruptible and apolitical policy makers in charge of the Chilean industrial policy. This gave shape to a social coalition, comprising domestic manufacturers, industrialists and professionals, in tacit alliance with urban labor and mediated by middle class political parties that supported the development strategy directed by CORFO's technocratic elite. According to Silva (1994), the technocratic group within CORFO managed to convince the other economic and social groups that industrial development was the only path for Chile's economic growth, becoming de facto the organic intellectuals of the state's industrialization process.

CORFO's ideology of industrialization was strengthened and reproduced by the internal cohesion and common professional training of the technocratic functionaries. Senior positions in the organization were gradually replaced, when required, by younger staff of intermediate hierarchy within the agency. This recruitment process was also facilitated by the fact that several of CORFO's top managers also taught at the School of Engineering in the University of Chile, having the opportunity to meet and enroll new technicians (Silva, 1994).

Corfo represented a certain political sector of the country; it represented an ascending industrialist middle class that had allied itself with the prior exports oligarchy. It was an alliance pro-industry, in a way leaving behind the agricultural development, because it was a model, let's say, of structuralist type. This urban alliance between entrepreneurs and workers in the sectors of mining, finance and industry expressed itself in CORFO and in a policy that fundamentally sought to attain a larger industrialization. ${ }^{95}$

Between 1939 and 1965, CORFO designed and implemented the country's Electrification Plan, the Coal Development Plan, the Fishing Development Plan

\footnotetext{
94 Silva, Patricio (1994) "State, Public Technocracy and Politics in Chile, 1927-1941". Bulletin of Latin American Research, vol. 13 No. 3 p. 290.

${ }_{95}$ Author's interview, former vice-president of CORFO and Ministry of Energy. Santiago de Chile, Chile, June 24, 2011.
} 
and the Industrial Promotion Plan (Soms, 2010). CORFO also created seven enterprises in the mining, steel, electricity, oil and rubber sectors throughout these years, ${ }^{96}$ laying the basis of a mixed economy in Chile. The developmental state apparatus and the centrist and center-left parties were the threads holding together the different interests that this developmental strategy involved. According to a former president of CORFO:

CORFO tells the story of a public organization that paved the basis for industrial development in Chile. It is there where the large state enterprises were created: energy, telecommunications, and waste collection. So CORFO is a key organism in the development of Chile since the beginning of 1940s. As time goes by it starts to naturally emerge the idea of planning as guidance for public action. Back then, when I was Ministry of Finance in 1964, 75\% of the investment in Chile came from the public sector; in consequence, if one could plan that public investment it would determine the situation of the entire economy. Behind that concept of powerful state, there was not only the influence from ECLA but also, there was a certain consensus around this idea inside the country. ${ }^{97}$

By the end of the 1950s, this equilibrium had started to change. The inwardoriented model adopted for thirty years had begun to exhaust, with most of the easy and obvious substitution of imported goods having already been made. Industrial growth was rapidly slowing down and balance of payment difficulties had become chronic. Public expenses regarding industrial promotion policies as well as onerous social welfare contributed to strong inflationary pressures (Silva, 2007). New economic measures and fiscal adjustments were needed, although many of them were detrimental to some of the sociopolitical actors that had supported the establishment of the economic growth model. Tension was growing within the social support coalition for import substitution industrialization concerning who was to pay for the costs of adjusting.

Jorge Alessandri (1958-1964), supported by conservative political parties, won the presidential contest in March 1958. Alessandri faced difficult decisions that were driven as much by political needs as economics. The government focused on controlling inflation, mainly by placing a ceiling on wages, balancing the state

\footnotetext{
${ }^{96}$ Sociedad Abastecedora Minera; Electromat SA; Compañía de Acero del Pacífico (CAP); Laboratorio Chile SA; Industria Nacional de Neumáticos (Insa); Manufacturas del Cobre (Madeco); Empresa Nacional del Petróleo (Enap).

${ }_{97}$ Author's interview, former president of CORFO and MIDEPLAN director. Santiago de Chile, Chile, June 22, 2011.
} 
budget and liberalizing Chile's tariff regime. These economic policies hit hard on organized unions and its left-wing and centrist political party allies, helping to accelerate the incipient process of party polarization. Socialists formally adopted Marxist-Leninist positions, while the right started to defend more economic liberal reforms (Valenzuela and Scully, 1997).

Based on these ideas and influenced by the Alliance for Progress, the electoral campaign of 1963-1964 brought the urgency of planning to the political debate. Both candidates, Salvador Allende (Popular Action Party) and Eduardo Frei (Christian Democracy Party), declared in their programmatic documents their intention to use economic planning as a fundamental government instrument. During his intervention at the $49^{\text {th }}$ plenary meeting, Salvador Allende stated: "We will create a central planning office as a fundamental instrument of government, with the specific function of translating our programmatic lines in concrete action plans. For this, we will have the active participation of different sectors at the national level, and agreements signed by employers and workers". In similar fashion, Eduardo Frei, in a letter to his campaign programmatic director, said: "The plan calls, for its successful implementation, an organic team, possessed of a spirit and a mystic, courageous to drive Chile forward" (Soms, 2010, p. 27).

Both candidates agreed on creating a separate central planning agency from CORFO, responsible for planning the state intervention in the economy as well as coordinating policy formulation and implementation. As a former vice-President of CORFO indicates:

The economic teams of both candidates, influenced by ECLA, firmly believed that political decision making would increasingly become focused on macro-economic policies, and that such decision making would require expertise on economic models. Therefore, the creation of a central planning office was seen as an effort to implement an economic policy based on innovative interpretations of development that surpassed the engineering vision of development of CORFO. Besides, taking out planning from CORFO responded to an attempt, from both left and right, to cut the domain of the coalition that for 30 years had exercised a great influence over the Chilean industrial policy. ${ }^{98}$

Historical accounts regarding the creation of CORFO attest the existence of all elements of the causal mechanism derived for the structuralist-instrumental approach. There was a coalition interested in launching the agency, political

98 Author's interview, former vice-president of CORFO and Ministry of Energy. Santiago de Chile, Chile, June 24, 2011. 
struggle among various groups vis a vis the agency, and clear efforts between the executive and legislative branches to impose transaction costs to one another in order to keep control over the agency. Evidence for elements of the causal mechanism of the cultural perspective are also quite strong, in particular the socialization and reproduction of the entity's culture, particularly through the inside staffing promotion strategies and recruitment of professionals from the engineering school.

\subsection{The National Planning Office (ODEPLAN)}

In 1964, Eduardo Frei Montalva (1964-1970) won the presidential election. Consistent with his campaign proposals he organized a planning bureau inside the President's office in 1964. According to former Vice-President of CORFO:

Frei expressed that the old Alliance between the middle industrial class and the old exports oligarchy needed to end, he said those that had been excluded, particularly peasants and people from the countryside having had no opportunities were becoming a marginal sector. Action against this exclusion and to promote the agricultural development of Chile through an agrarian reform was needed. ECLA, precisely opens this window of opportunity for President Frei. So in order to intervene with a technical and economic logic ODEPLAN is created. ${ }^{99}$

According to Montecinos (2009), the National Planning Office (ODEPLAN) enormously increased the demand for economists. Through a collaborative agreement signed by ODEPLAN and the Center for International Studies at MIT, a group of US-trained economists with state of the art economic modeling capacities were recruited for the planning agency. Moreover, President Frei brought Jorge Ahumada from ECLA to work at ODEPLAN. Ahumada was a close friend to the President and was his economic advisor during the presidential campaign (Huneeus, 1998).

Over the next two years, the government and Congress debated about the need to create an official central planning agency within the executive branch. The creation of the agency was met with apprehension by the right party, as well as supporters of the import substitution industrialization model. Both groups opposed in Congress the enactment of the agency: the former disliked the idea of having more intervention in the economy through a powerful agency, while the latter did not

\footnotetext{
${ }^{99}$ Author's interview, former vice-president of CORFO and Ministry of Energy. Santiago de Chile, Chile, June 24, 2011.
} 
trust the replacement of CORFO as the key agency for economic policy making. ${ }^{100}$ Finally, in 1967, Congress passed Law $\mathrm{N}^{\circ}$ 16.635, approving the formation of ODEPLAN as a decentralized supra-ministerial agency in the office of the presidency. The agency was set up as the official advisory body for the President in all matters connected with the process of economic and social planning. As a former ODEPLAN director states:

ODEPLAN was very powerful, not only in terms of the functions that were assigned to the agency but more so because President delegated power to the agency. The President listened to what ODEPLAN had to say because its staff were all highly trained people that were close to the President as they had done their careers side to side; they all came from ECLA, internationally known functionaries. That was the key to ODEPLAN's power and its convenience for Frei. ${ }^{101}$

This law transferred the economic planning responsibilities from CORFO to ODEPLAN, as well as the elaboration of the national accounts. CORFO's planning department was relocated and integrated into the new central planning office (Leiva, 2010). Additionally, CORFO gave ODEPLAN a physical place to set up its offices. Law $\mathrm{N}^{\circ} 16.635$ granted ODEPLAN with the following functions:

a. Coordinate the preparation of the National Development, Economic and Social Plan

b. Forecast the behavior of the national economy and prepare socio economic projections for the middle and long run needs in the elaboration of the National Development Plan

c. Propose short and long run sectoral policies in line with the National Development Plan

d. Develop the technical instructions and tools to be followed by the sectoral ministries and other public organizations in the preparation of sectoral plans

e. Propose regional development policies

f. Propose to the President the annual public investment goals, and its composition, both by sectors and regions.

g. Establish the economic and social evaluation criteria for projects financed directly or indirectly by the state

\footnotetext{
${ }^{100}$ Based on Author's interview with former president of CORFO and MIDEPLAN director. Santiago de Chile, Chile, June 22, 2011.

101 Author's interview, former ODEPLAN director. Santiago de Chile, Chile, June 28, 2011.
} 
h. Coordinate with the Ministry of Finance the annual preparation of the investment projects

i. Propose to the President alternatives for financing the National Development Plan

j. Coordinate and target to various sectors/projects international technical assistance

k. Inform, both the President and Congress, about the implementation and achievements of the National Development Plan

1. Prepare the national accounts

ODEPLAN's director, Alvaro Marfan, was directly appointed by the President, while the directors of the sectoral and territorial branches were nominated by the ODEPLAN director in agreement with sectoral ministers and city mayors, respectively. The sectoral and territorial directors were accountable to both ODEPLAN's director as well as the institutional heads. The internal arrangement of the central planning agency comprised a National General Director, under whom three subunits depended: the National Sub-Director, the Regional SubDirector and an International Technical Assistance Department.

The National Sub-Director was responsible for global programming in terms of defining the middle-run macroeconomic program, and for the preparation of national accounts. The Regional Sub-Director was in charge of the Regional Planning Department and Regional Planning Offices (ORPLAC) responsible for making regional diagnosis and delineating regional development plans. Finally, the international Technical Assistance Department had the function of coordinating the international cooperation and preparing annual international requirements for assistance programs. Figure 1 depicts the 1967 ODEPLAN organizational chart.

At the end of the 1960s, ODEPLAN had a numerous staff of around 200 employees, most of whom had professional degrees (Huneeus, 2000). However, carrying out the planning functions at central, sectoral and regional levels presented a challenge due to the insufficient qualified staff in the public sector. To deal with this situation, various international missions from ECLA, the Ford Foundation and the Massachusetts Institute of Technology provided ODEPLAN with technical assistance on aspects related to the social evaluation of investment projects, economic forecasting, regional development and multi-sector models. This contributed to the qualification of the personnel that worked in the agency and, over time, not even the Finance Ministry had comparable technical staff (Montecinos, 2009). 
Figure 1

Organizational Chart: ODEPLAN, 1967

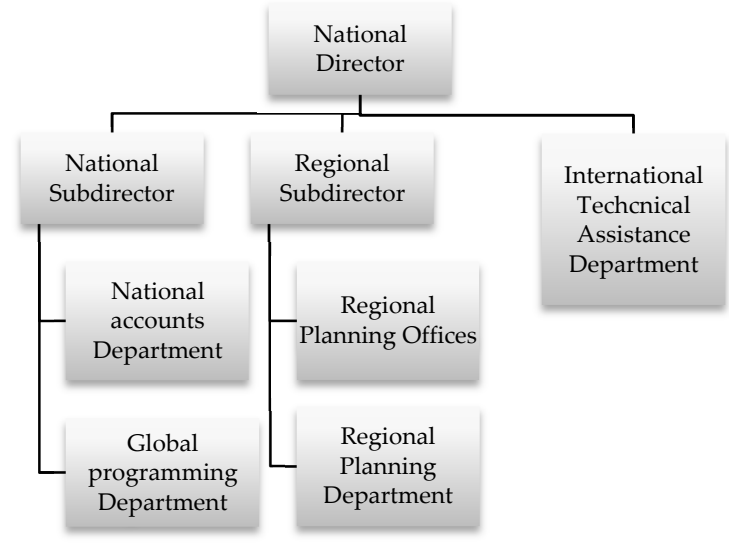

Source: Luis B Mejía, 2014

In addition to ODEPLAN, the government created the Economic Committee of Ministers. This body was intended as a decision making and economic policy coordination organization chaired by the Ministry of Finance and made up by other ministers dealing with economic affairs. ODEPLAN exercised as the technical secretariat of this Committee. As a former CORFO and MIDEPLAN director points out:

As finance minister, I presided over the Economic Committee of Ministers. I decided to invite the planning office to be the technical secretary of this committee. This was done to give life to the organization. That is important for the history of the agency, as it was the step to occupy an important role in the design of economic policy in the country (...) So, in practice, the planning office was not isolated. It had two poles to the ground. The first was through the technical secretariat of the Economic Committee, and, the second one was Alvaro Marfan who was a close friend of President and influenced him. ${ }^{102}$

Therefore, ODEPLAN played an active part in the economic policy making throughout this period, giving the agency a great influence over other public sector organizations. The Frei administration focused on reducing inflation, accelerating economic growth, redistributing income, nationalizing the copper sector and undertaking land reform. In addition, Frei boosted the peasant unionization and

\footnotetext{
${ }^{102}$ Author's interview with former president of CORFO and MIDEPLAN director. Santiago de Chile, Chile, June 22, 2011.
} 
the organization of the unorganized marginal sectors. Putting this into practice required the deployment of state action through its public organizations, and ODEPLAN was the agency in charge of coordinating this intervention. As Soms (2010) states, this public action required the existence of a central agency reporting directly to the presidency of the Republic, with branch offices in each of the ministries and public enterprises, as well as the regions. For this purpose, ODEPLAN, following ECLA's blue print, produced a series of instruments that contained formal planning models, econometric projections, capital-output ratios, saving coefficients and an input-output matrix.

Although the rate of economic growth improved during 1964-1966, none of these policies could stop the economic crisis of 1967. In fact, industrial and GDP growth rates slowed down and inflation increased during this year. However, the more serious difficulties came from sociopolitical tensions. The party system no longer mediated politically conflicting interests between members of the social coalition that supported import substitution industrialization (Silva, 2007). The Christian Democrats exasperated leftist parties by organizing the peasants and marginal classes in their effort to become a majority party. Socialist and communist parties believed that the state role had always been to favor the basic interests of monopolistic capitalism, and subsequently intensified their revolutionary rhetoric (Valdés, 1995). Finally, the expanded support that socialist and communist parties received prompted conservatives to come closer the Christian Democratic Party, which had already displaced the Radical Party as the dominant centrist party.

In September 1970, Salvador Allende won the presidential elections as leader of the Popular Unity coalition (Communist Party, Socialist Party and Unitary Popular Action Movement). Allende took office as the first Marxist to be democratically elected as President in any country of the Americas.

President Allende proposed an ambitious package of structural and economic reforms, with his main transformations including nationalization of the copper industry and banks, improving income distribution, state control over investment proceeds and land reform. These policies were new departures in a country where state economic activity had traditionally been supportive of, rather than competitive with, private capital (Goldberg, 1975). During the first year of government, Allende nationalized the mining of cooper, iron, coal and iodine. His government also expropriated several iron, cement, textile and beer enterprises, as well as sixteen commercial banks and over 1,400 rural properties (Soms, 2010). A high-level bureaucrat from ODEPLAN at that time remembers: 
With the arrival of Allende, ODEPLAN and CORFO are used to articulate an attempt at centralist planning. CORFO recovered part of its lost shine as it was the organization used by Allende to administer nationalization and the expropriation of businesses. For example CORFO's technical committees in the sectors of cement, textiles and food production became the instruments for state intervention. In the meantime ODEPLAN was creating a national plan, action plans for the nationalized enterprises, research on income and general studies of the Chilean economy, etc. ODEPLAN was monitoring the road toward the transition of Chile into socialism. ${ }^{103}$

Economic and social planning took on a greater role within the government of the Popular Unity. Planning was seen as a necessary tool for carrying out the political, economic and social program proposed by Allende and was intended to replace the market in its work as producer and regulator (Leiva, 2010). These ideas were reinforced by the thoughts of exiled leftist intellectuals who had arrived in Santiago from Brazil, Argentina and other neighboring countries (Celso Furtado, Fernando H Cardoso, Theotonio Dos Santos, Ruy Mario Marini, among others), and by a radicalized version of developmentalism from some of ECLA's sector (Montecinos, 2009). Among this group was Pedro Vuskovic, who worked for ECLA for almost 20 years, culminating his carrier in the organization as Director of the Development Division. Vuskovic was the author of the economic platform of the Popular Unity campaign, as well as the economic plan of Allende's government. ${ }^{104}$

In order to get underway and implement his reforms, Allende reorganized the National Planning System ${ }^{105}$ and ODEPLAN in particular, making it the leading agency in charge of coordinating and ensuring consistency of the institutional and economic restructuring. President Allende elevated ODEPLAN to the status of autonomous ministry and changed the internal structure of the agency in some aspects (Montecinos, 2009). First, the director of ODELAN was given ministry rank by presidential decree. Putting ODEPLAN's director in this position empowered him as the official coordinator of the government reform plan. Second, additional departments were attached to the existing national and regional sub-directions. The coordinating role of ODEPLAN was exercised through the network of sectoral planning offices that had been created in most ministries. These offices acted as

\footnotetext{
${ }^{103}$ Author's interview, former ODEPLAN top-level official. Santiago de Chile, June 20, 2011. ${ }^{104}$ Author's interview with former president of CORFO and MIDEPLAN director. Santiago de Chile, Chile, June 22, 2011.

105 The National Planning System was conform by ODEPLAN and its regional offices, the sectoral planning offices, the Finance Ministry's Budget Office and CORFO.
} 
counterparts in the definition, monitoring and evaluation of the sectoral development plans. Third, Allende replaced all top and middle positions of the organization with people who shared his ideological convictions. As a former president of CORFO points out:

I went to talk with President Allende to present my resignation as vicepresident of CORFO, and I talked to him about it. President, I said, I think that from the standpoint of a socialist government CORFO is an essential organization, but I think that CORFO is an organization that must be kept under strict technical standards. I said, here are first class people, people of great experience in CORFO, which have made a career here. These officers are technicians who are well aware about the public sector and its businesses. Then he told me to give him a list of those people he should keep, and what happened next was that he fired all the people that were on the list. And exactly the same thing happened in ODEPLAN, he changed everybody for people who shared his political and economic thoughts. ${ }^{106}$

Under the new institutional arrangement, the National Sub-Director was responsible for the recently created departments of Strategy and Middle Run Plans, Annual Planning and Economic Balance and External Commerce Planning. These new departments reflected the strong emphasis of Allende's government on formulating and evaluating annual and six-annual socio-economic development plans. For its part, the Regional Sub-Director was assigned with three new departments, the Territorial Analysis Department, Long and Middle Run Territorial Planning and Regional Annual Plans, reflecting the government's intention to promote economic planning at the territorial level. Figure 2 depicts the 1970 ODEPLAN organizational chart.

By decree $N^{\circ} 303$ of 1971, President Allende created the National Development Council responsible for discussing the short, middle, and long run development plans prepared by ODEPLAN. Moreover, it also had responsibility in advising the President about different ways of financing these plans. The Council was chaired by the President and composed by representatives of the ministries, six members from the working sector, six delegates from the entrepreneurs, two representatives from the professional colleges and one representative of youth.

\footnotetext{
106 Author's interview with former president of CORFO and MIDEPLAN director. Santiago de Chile, Chile, June 22, 2011.
} 
Figure 2

Organizational Chart: ODEPLAN, 1970

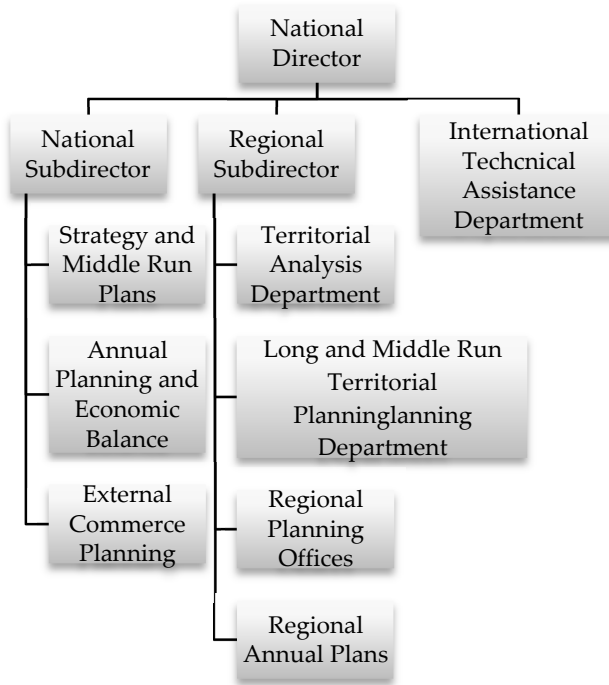

Source: Luis B Mejía, 2014

By 1972, the political situation had deteriorated in response to Allende's reforms, with the opposition parties, middle classes, business and professional elites, small businessmen (particularly the independent truckers) and even some factory workers refusing to accept any restrictions on their standards of living and beginning to coordinate massive mobilization protests. According to Silva (1993), the "socialist experiment" united capitalists, landowners, the middle class and their political party allies against labor, peasants and leftist parties.

The United States vetoed Chilean applications for loans at the US Export-Import Bank and other commercial banks, as well as from International Financial Institutions. This credit blockade forced Allende to use the Chilean foreign currency reserves, which resulted in a drastic 58\% reduction of imports of nonagricultural consumer goods ${ }^{107}$ (Goldberg, 1975). Additionally, inflation shot up to 605 percent in 1973, while the fiscal deficit was 30.5 percent of GDP in the same year. Ultimately, the collapse of the economy, the severity of class conflict and the spiraling polarization and confrontation of political actors led to the downfall of democracy (Silva, 2007). On September 11, 1973, the Chilean military staged a coup d'état against Allende.

${ }^{107}$ Due the scarcity of dollars. 
During this period, the narrative accounts provide consistent evidence of the politics surrounding the agency, matching some of the parts of the causal mechanism of the structural- instrumental approach. Frei and Allende, in the 1963 presidential campaign, despite their opposite political positions both agreed on the need to create a planning agency, one different from the already existent CORFO. They were echoing the Alliance for Progress that was promoting the creation of such agencies in the region, and thus represented a source of external financing for Chile. It was also the opportunity to build up new coalitions among sectors that had been left out by the long-dominance of CORFO's coalition. Once in power President Frei surmounted the Congressional opposition and created ODEPLAN directly under his domain, and welcomed technical assistance by various external actors to further strengthen the technical skills of the already qualified Chilean professionals. Under President Allende there is a rational choice to use the agency, as the bastion of his statist social and economic transformations, as well as a place to post his political affiliates.

With the removal of Allende, a military junta took control of the government suspending the constitution and the Congress, outlawing political parties and depriving labor unions of political activities and bargaining rights. The junta was comprised by General Gustavo Leigh representing the Air Force, General Augusto Pinochet representing the Army, Admiral José Toribio Merino representing the Navy and General César Mendoza representing the Carabineros. Augusto Pinochet acted as head of the state from 1974 to 1990, when democracy was reestablished.

One of the first steps taken by the military authorities was to form an economic team capable of dealing with an inflation that exceeded 800 percent, a short supply of goods and a paralyzed industry (Valdés, 1995). The Navy, which initially took charge of the economy, not only lacked a technical background in economics, but also a detailed strategy to manage the situation. Admiral Lorenzo Gotuzzo, newlyappointed Minister of Finance, and Admiral Jose Toribio Merino, who was responsible for the coordination of the economic front, approached Roberto Kelly, a former marine and personal friend of Merino, who had close links with a group of young professionals that had a plan to solve the economic problems of Chile. A former ODEPLAN director describes the event as follows: 
Robert Kelly is appointed as director of ODEPLAN. Kelly was a man close to Merino, Admiral chief of the navy. From what I heard, the military Junta faced the hard challenge to govern the country in midst of the crises. So, what they did was to part responsibilities, the navy in charge of the economy, the air-forces in charge of the social areas and the military responsible for interior affairs. So, Kelly builds up a team of young economists, most of them recently graduated from the Economics School of Chicago University. Beginning from there the idea of change and economic reforms started to incubate. ${ }^{108}$

Rolf Luderd, cited by Valdes (1995), refers to the group of young economists as follows:

The group's existence and success was probably made possible by the common educational background of its members. In the mid-fifties, Chicago University and the Universidad Católica de Chile had initiated a program for educational exchange. Under this agreement, Chicago University sent professors to Chile to do research and accepted Chilean graduate students (...) Up to 1973, on their return to Chile many of these economists became professors at local universities. Others worked for the government, particularly during Frei's administration. The rest joined the main firms in Chile. But, they all formed a single community sharing the same technical language, a rationalistic approach and eagerness to contribute to creating a prosperous, fair and free society. Most of these economists are currently known -whether they like it or not- as the Chicago Boys. ${ }^{109}$

This group of economists had worked in the preparation of the economic program of the right-wing candidate Jorge Alessandri during the presidential elections of 1970. After Alessandri's defeat in the ballot, the group dedicated itself to providing information and economic guidance to Allende's opponents in Congress, as well as writing critical opinion reviews, in conservative journals, against the Popular Unity government (Montecinos, 2009). This experience culminated in the drafting of an economic development program, which came to be known as the brick, to be implemented after a possible military intervention (Castiglioni, 2001).

The Chicago Boys shared an approach to economic and social policy based on the premise of maximizing the private sector's role in determining the political and

\footnotetext{
108 Author's interview, former ODEPLAN director, Santiago de Chile, Chile, June 20, 2011. 109 Valdés, Juan Gabriel (1995) Pinochet's Economists. The Chicago School in Chile. Cambridge: Cambridge University Press.
} 
economic priorities of the state. In opposition to the Keynesian economic framework and its counter structuralist approach advanced by ECLA, these neoliberal economists believed that the long implementation of Import Substitution Industrialization in Chile had almost shifted the country to socialism. They thought that the traditional industrialist strategy had to be replaced with an export-oriented model primarily based on commodities (agricultural products, forestry, minerals, etc.), and that banks and credit should be kept in private hands.

Kelly, politically supported by the Navy, was appointed as director of ODEPLAN. Although "the brick" was not accepted as the framework for the adoption of economic policy during the first few years of military rule, the Chicago Boys were invited as advisors by the government. They were initially placed in second-level positions inside ODEPLAN, as well as other ministries and state agencies. From 1973 to 1975, the military officials in charge of the economy brought about an economic policy that did not share the radical neoliberal views of the Chicago Boys, focusing on balancing the budget and gradually curbing inflation (Valdés, 1995). However, by 1975, Chile's poor macroeconomic performance (inflation mounted to 340.7 percent), exacerbated by 50 a percent decline in the international price of copper and the oil crisis, prompted technocrats at ODEPLAN to doubt the gradualist strategy, favoring a shift that culminated in the implementation of the Chicago Boys' policy recommendations (Castiglioni, 2001). As a former ODEPLAN director states:

In ODEPLAN, the idea of change began to hatch. ODEPLAN officials started thinking about the economic reforms that the country needed. While the Finance Ministry and Economics Ministry had to deal with the daily difficulties of the economic situation, ODEPLAN was ahead thinking about the economic reforms. ${ }^{110}$

After a period of time, several of the Chicago Boys were able to position themselves as directors of the main economic policy making bodies, with ODEPLAN becoming the institution upon which market-oriented economic policies such as the privatization of state-owned companies, economic liberalization and stabilization of inflation were directed. A former CORFOS president and ODEPLAN director explains why ODEPLAN was important for the military regime:

${ }^{110}$ Author's interview, former ODEPLAN director. Santiago de Chile, Chile, June 21, 2011. 
None of them were thinking in ODEPLAN as a planning agency, they simply wanted the government to see the agency as taking efficient actions. I think ODEPLAN suited a purpose for the Military and for the economic team given the wealth of information it had. It had an economic information system that was there from before them and that they incremented. ${ }^{111}$

Chicago Boys, including Sergio de Castro, Pablo Baraona, Sergio Undurraga, Alvaro Bardón, Miguel Kast, and Emilio Sanfuente, among others, became leading figures in Pinochet's administration. For instance, Sergio de Castro was Minister of Economics from 1975 to 1976, and subsequently Finance Minister until 1982. Pablo Baraona was Minister of Economics from 1976 to 1978, while Miguel Kast was SubDirector of ODEPLAN from 1974 to 1979, then director of the agency from 1978 to 1980 and finally Minister of Labor until 1982 (Valdés, 1995).

By 1975, General Pinochet had appointed Jorge Cauas ${ }^{112}$ as Finance Minister, and Sergio de Castro as Ministry of Economics. Moreover, Pinochet signed Decree 966 of April 1975, turning the Ministry of Finance into a supra ministry, which involved making it responsible for the coordination of the economic system and therefore having direct authority over all government offices involving economic policy (Castiglioni, 2001).

Led by Sergio de Castro and Jorge Cauas, from 1975 to 1980 the Chicago Boys introduced a package of structural reforms in the Chilean public sector that focused on three areas: the liberalization of the price system and markets; the opening of foreign trade and external financing operations; and reduction of government intervention in the economy. Furthermore, the Chicago Boys promoted a radical retrenchment of social policy. This period was characterized by a process of macroeconomic recovery. The average GDP growth was 7.2 percent, with a fiscal surplus and positive balance in the non-financial public sector attained. ${ }^{113}$ Table 10, designed by Meller (1990), summarizes these structural changes.

\footnotetext{
111 Author's interview with former president of CORFO and MIDEPLAN director. Santiago de Chile, Chile, June 22, 2011.

112 Engineer and economist from Columbia University, who shared the ideological position of the Chicago Boys.

113 Valdés, Juan Gabriel (1995) Pinochet's Economists. The Chicago School in Chile. Cambridge: Cambridge University Press.
} 
Table 10

Structural change under the Chicago Boys (first phase)

\begin{tabular}{|c|c|c|c|}
\hline & & Situation in $1972-73$ & Post-1973 \\
\hline 1 & Prices & Generalized price control & $\begin{array}{l}\text { Freed prices (excluding } \\
\text { wages and the exchange } \\
\text { rate) }\end{array}$ \\
\hline 2 & Privatization & $\begin{array}{l}\text { The state control over } 500 \text { firms } \\
\text { and bank }\end{array}$ & $\begin{array}{l}\text { In 1980, twenty-five } \\
\text { companies (including a } \\
\text { bank) belonged to the } \\
\text { public sector }\end{array}$ \\
\hline 3 & Trade regime & $\begin{array}{l}\text { Multiple exchange rates; import } \\
\text { quotas and bans; high tariffs } \\
\text { (average of } 94 \text { percent, maximum } \\
\text { of } 220 \text { percent); prior deposits on } \\
\text { imports ( } 10,000 \text { percent) }\end{array}$ & $\begin{array}{l}\text { Unified exchange rate; } \\
\text { uniform tariff of } 10 \\
\text { percent; no other } \\
\text { barriers to trade }\end{array}$ \\
\hline 4 & Fiscal regime & $\begin{array}{l}\text { Taxes on buying and selling; } \\
\text { swollen public employment; high } \\
\text { fiscal deficit }\end{array}$ & $\begin{array}{l}\text { Value added tax ( } 20 \\
\text { percent); cuts in public } \\
\text { employment; fiscal } \\
\text { surplus (1979-81) }\end{array}$ \\
\hline 5 & $\begin{array}{l}\text { Domestic capital } \\
\text { market }\end{array}$ & $\begin{array}{l}\text { Controls on interest rates; } \\
\text { nationalization of the banking } \\
\text { sector, credit controls }\end{array}$ & $\begin{array}{l}\text { Market-set interest } \\
\text { rates; privatization of } \\
\text { the banks; liberalization } \\
\text { of the capital market }\end{array}$ \\
\hline 6 & Capital account & $\begin{array}{l}\text { Absolute control on capital } \\
\text { movements; the government is the } \\
\text { main external debtor }\end{array}$ & $\begin{array}{l}\text { Gradual liberalization of } \\
\text { capital movements; the } \\
\text { private sector is the } \\
\text { main external debtor }\end{array}$ \\
\hline 7 & Labor regime & $\begin{array}{l}\text { Powerful unions with strong } \\
\text { bargaining power; law of } \\
\text { performance; obligatory salary } \\
\text { increases; high proportion of non- } \\
\text { salary labor costs ( } 40 \text { percent } \\
\text { equivalent of salaries) }\end{array}$ & $\begin{array}{l}\text { Atomized unions with } \\
\text { no bargaining power; } \\
\text { simple dismissal } \\
\text { procedure; drastic fall in } \\
\text { real salaries; low } \\
\text { proportion of non- } \\
\text { salary labor costs ( } 3 \% \\
\text { equivalent of salaries) }\end{array}$ \\
\hline
\end{tabular}

Source: Meller, Patricio (1990) "Revisión del Proceso de Ajuste Chileno de la Década del 80". Colección de Estudios CIEPLAN: º30 p. 7.

However, the Chicago Boys were not just a group of neoliberal technocrats, as they are often represented. Silva (1993) points out that many of the key figures of the Chicago Boys had close binds with the international conglomerates like Edwards, Cruzat-Larrain and BHC groups. For instance, Sergio de Castro (Ministry of 
Finance) was a close friend of Manuel Cruzat, one of the two major figures of the Cruzat-Larrain economic group. In the same way, Pablo Baraona (Ministry of Economy and President of the Central Bank) and Francisco Soza (Vice-president of CORFO) were on the board of directors of well-known Cruzat-Larrain corporations. By accepting the Chicago Boys, Pinochet formed an alliance with the international conglomerates, which allowed him to control the most dynamic economic sectors, while the international conglomerates had a privileged access to policymakers (Silva, 1993).

During this period, ODEPLAN managed to attract a large number of recent graduate professionals to work for the agency. To enroll these young people, ODEPLAN worked closely with the Catholic University. Between 1973 and 1989, ODEPLAN signed 14 institutional agreements ${ }^{114}$ with the Catholic University, yet none during this period with the Economic Institute of the University of Chile, where outstanding professionals were also working. According to Huneeus (2000), this recruitment strategy responded to a plan to engage professionals based not only on their qualifications, but also on their political orientation. According to a former ILPES director:

Well, what happens is that sometimes particular circumstances play a role in organizations. Inside the Universidad Católica there was a strong movement, led by Jaime Guzmán; he became one of the ideologists of the military regime. And around him, other people like Miguel Kast, a disciplined follower, very active and he then ended working in ODEPLAN. ${ }^{115}$

Following Huneeus (2000), during the 1970s Gremialistas were the leading political force in the Catholic University, controlling the principal student unions. Gremialism was a right wing student movement, founded in 1967 by Jaime Guzman, which opposed the economic and political ideas of the left and supported the neo-liberal solutions that the government was implementing. ODEPLAN's director, Miguel Kast, a well-known gremialista, saw in this situation the opportunity to strengthen and reproduce the internal cohesion of the agency. ODEPLAN recruited capable professionals willing to take political commitments with the authoritarian regime. In this sense, ODEPLAN became vitally important for Gremialismo, providing the regime with good servers who could be allowed to build their own political movement in the medium- and long-term (Huneeus, 2000).

114 Throughout these contracts, ODEPLAN transferred U\$12,658,261 to the Catholic University.

${ }^{115}$ Author's interview, former ILPES director, Santiago de Chile, June 23, 2011. 
ODEPLAN also created a scholarship program offering employees the possibility to carry out post-graduate studies abroad. The recipients of the scholarship were committed to return to the country and work in the public sector for twice the amount of time that they spent abroad. The idea of ensuring a job after returning was appealing to the young Chilean professionals. In addition, by 1978 ODEPLAN, with support from the Catholic University and sponsored by the Interamerican Development Bank, designed and put into practice a program to train employees on the social evaluation of public spending. Miguel Kast appointed Ernesto Fontaine, PHD economist from University of Chicago, as director of the program. The course was taken by hundreds of Chilean civil servants, from the central and regional government, as well as many professionals from other countries in the region. The program played an important role in the diffusion of neo-liberal ideas among the public servants. As Huneeus (2000) states:

The Institute was one of ODEPLAN's most important collaborators in generating a group of elite government professionals, training hundreds of students in public administration and spreading the influence of the Chicago Boys among economists from all over Latin America who participated in the program. These participants soon gained international prestige and were able to influence the economic development of the entire region. ${ }^{116}$

From mid-1970 until 1990, ODEPLAN re-assumed the original functions established by law 16.635 of 1967, and adapted it to the new tasks appointed by the military government. Many of the regime's social policy reform projects were partly or entirely drafted in ODEPLAN. Specifically, ODEPLAN was responsible for designing policies to combat extreme poverty, and public sector reform. A former MIDEPLAN director states:

116 Huneeus, Carlos (2000) "Technocrats and Politicians in Authoritarian Regime. The ODEPLAN Boys and the Gremialist in Pinochet's Chile". Journal of Latin American Studies: $\mathrm{N}^{\circ} 32$ 
All the system of surveying and data collection for social indicators come from Kast. At that time I was working in the Universidad Católica and Jorge Causa, ministry of Economy contacted me to work in the characterization and identifications of Chile's poorest segments of the population. We sold the idea to Kast in ODEPLAN and he accepted to fund that project in collaboration with the Universidad Católica. So, we did the first map of Chile's poverty. Kast was a person who had a privileged position inside government, he had large influence in policy making and he was able to do this because he had outstanding people and tools in ODEPLAN. ${ }^{117}$

Furthermore, the agency assumed duties related to the formulation and evaluation of public investment projects. The planning office created an investment project bank and designed criteria for undertaking economic and social evaluation of all the government's investment projects (cost benefit analysis). This meant that all ministries and other public organizations had to submit their investment projects to ODEPLAN for approval prior to sending them to the Ministry of Finance. During this period, the Budget Bureau rendered its traditional authority in the budget process to ODEPLAN (Montecinos, 2009). According to a top-level ODEPLAN official:

By the end of the 1970s, ODEPLAN takes a very important part in the evaluation of investment projects. This was a project supported by Universidad Católica and by the IDB. Professor Ernesto Fontain, who worked for the IDB in Washington came to the Universidad Católica to set up the project evaluation program. There he had bureaucrats coming from many countries in Latin America to take the course and from there it spread out, to ODEPLAN, to various sectoral Ministries. ODEPLAN starts providing the technical criteria for project evaluation. ${ }^{118}$

Additionally, ODEPLAN acted as the technical secretariat of the recently-created Economic Committee, Social Committee and National Commission for Administrative Reform. Together, these responsibilities gave ODEPLAN leverage over other public agencies.

By the late-1970s, ODEPLAN had added a new Department of Studies and Research in charge of analyzing and preparing policy recommendations for the pension system, capital markets and tax reforms. At the beginning of the 1980s,

\footnotetext{
${ }^{117}$ Author's interview, former MIDEPLAN director. Santiago de Chile, Chile, June 22, 2011.

${ }^{118}$ Author's interview, ODEPLAN's top official. Santiago de Chile, Chile, June 23, 2011.
} 
ODEPLAN transferred the function of registering national and regional accounts to the Chilean Central Bank. Figure 3 depicts the ODEPLAN organizational chart during the 1980s.

\section{Figure 3}

\section{Organizational Chart: ODEPLAN, 1980s}

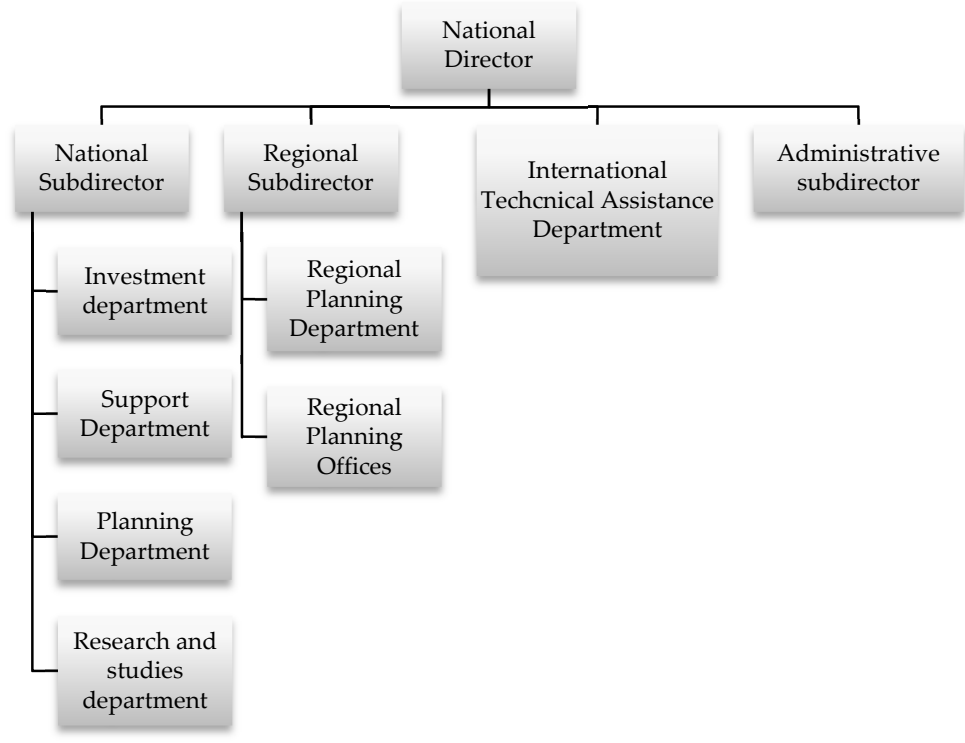

Source: Luis B Mejía, 2014

According to Silva (2000), the supremacy of the Chicago boys reached its highest point at the time the 1980 Constitution was being adopted. On September 11, 1980, the military government held a referendum in which citizens were asked about their approval to change Chile's 1925 Constitution. The result was a victory for those in favor of the new bill $(67.04 \%$ against $30.19 \%)$. With the new Constitution, President Pinochet was placed above the military junta, while his presidential term was prolonged until 1989. However, by the end of 1981 the Chilean Gross National Product had declined by 14 percent and the population's confidence in the government and its economic policies began to rapidly melt (Silva, 2000). In response to the economic situation, the Chicago Boys adopted an expansive fiscal policy and hoped that external disequilibria would be overcome by automatic adjustment.

By 1982, the contraction of the world economy hurt Chilean exports, with the country entering its worst economic recession since the 1930s. Industry and 
construction contracted by over 20 percent, effective unemployment hit 30 percent, bankruptcies tripled and the private financial system suffered losses of twice its capital, on average. As a result, GDP fell by 15 percent and the central bank lost over 45 percent of its international reserves. General Pinochet invited the Finance Ministry to resign and reshuffled his cabinet, taking out the Chicago Boys from government's top positions (Valdés, 1995). During this year, three different generals from the Army were appointed as directors of ODEPLAN.

Pinochet replaced the Chicago Boys with militaries and a moderate right-wing heterodox economic team, able to implement more pragmatic policies in the light of the economic crisis. After the adoption of a series of measures (including currency devaluation, price bands for the import of agricultural products, regulation of the financial system and the provision of subsidies to the private sector), the economy began to recover to the point that Chile started to enjoy high GDP growth rates. The military regime subsequently decided that the economic situation was sufficiently safe to resume and reinforce the neo-liberal reforms. Accordingly, in February 1985 Pinochet appointed Hernán Büchi, who had collaborated with the Chicago Boys since 1975 and had been ODEPLAN's director from 1983 to 1984, as Minister of Finance. Büchi continued to implement the pro market reforms and was shortly able to restore the confidence of international financial agencies in the Chilean economy (Silva, 2000).

According to the transitional provisions of the 1980 Constitution, a referendum was scheduled for October 1988, to vote for or against a new eight-year presidential term for Pinochet. This time, those voting against won, attaining 54.5\% of the votes. Facing internal and international opposition, Pinochet called for presidential and parliamentary elections. In 1989, Patricio Aylwin (1990-1994), representing a coalition comprising center-left parties (the Coalition of Parties for Democracy) was elected new President and the country returned to a democratic system.

The tracing of events of ODEPLAN's evolution throughout the military's regime in Chile is quite interesting as there is a mix of evidence that nicely fits the observable implications proposed by all four theoretical approaches to understanding institutional change. Coinciding with elements of the structural-instrumental approach, the military quickly saw in ODEPLAN a wealth of information that served the regime to implement Chile's structural reforms thus decided to preserve the agency. Consistent with the cultural institutional approach this period provide many examples of the feed-back mechanisms in place, like scholarships, recruitment, and exchanges with Universidad Católica that allowed the "culture" of the Chicago boys to settle and reproduce itself in ODEPLAN. From the standpoint 
of the Environmental approach, the whole adoption of the neoliberal reforms by the Chicago boys took the form of diffusion by persuasion given the training of Chilean professionals in the Economics School of Chicago University. Finally, the predictions of the task specific approach to institutional change were also evidenced throughout this period in that ODEPLAN's functions and internal departments were changed and adapted to respond to the needs of the neoliberal economic model, now in vogue. Transversal to all these elements of the causal mechanisms, it is noticeable that once again the President is determinant in originating organizational change. Significant evidence pointing to this statement is that when the economic conditions in 1982 weakened, President Pinochet faced no restriction to withdraw top personnel from the Chicago boys' line of thinking at ODEPLAN, replacing them with military that had a more moderate economic team. But few years later Pinochet once again called back the Chicago Boys to direct ODEPLAN when economic confidence was resumed.

\subsection{The Ministry of Planning-MIDEPLAN}

President Aylwin's development policy was based on an explicit pro-growth strategy focused on increasing social expenditure and continuing to open the economy to world trade. Additionally, the government followed a conservative fiscal policy, simultaneously pursuing a budget surplus and reduction of public debt. ${ }^{119}$ This strategy required the existence of an agency in charge of coordinating the definition and implementation of the social policy, with ODEPLAN duly chosen to perform this task. ${ }^{120}$

In May 1990, President Aylwin presented a bill to Congress requesting the transformation of ODEPLAN into a new Ministry of Planning. The idea behind this bill was to elevate the organization's level of political and administrative responsibility. According to the executive, only in that way would the planning agency reach the necessary hierarchy for coordinating social policy. The appointed minister, Sergio Molina, defended the transformation of ODEPLAN into MIDEPLAN in these terms:

\footnotetext{
119 World Bank (200) "Shanghai Poverty Conference: Case Study Summary"

${ }^{120}$ Based on Author's interview with former president of CORFO and MIDEPLAN director. Santiago de Chile, Chile, June 22, 2011.
} 
The project aims to meet the requirements of social development in the poorest sectors, through mechanisms to ensure efficient and equitable distribution of available resources for this purpose. For this, we will grant MIDEPLAN its own functions and powers as a Ministry of State. Only then, the government authority responsible for the identification of development policies, evaluation of investment projects in the public sector, coordination of social policy and regional development planning can exert the hierarchy needed to meet these functions. ${ }^{121}$

The transformation of ODEPLAN into MIDEPLAN was questioned by the conservative opposition party in Congress, arguing against the necessity of transforming the structure of an agency that was well functioning, as well as the effectiveness of the proposed new agency. The then Senator Sebastian Piñera (National Renewal Party) questioned the necessity of creating a Ministry of Planning when more than 80 percent of investment was in hands of the private sector. ${ }^{122}$ However, the opposition under a conciliatory spirit marked by the return of democracy finally authorized President Aylwin to create MIDEPLAN.

Law $\mathrm{N}^{\circ} 18.989$ of 1990, transformed ODEPLAN into the Ministry of Planning and Cooperation-MIDEPLAN. This law gave MIDEPLAN very broad functions, including social planning, as well as the development of programs aimed at overcoming poverty and including disadvantaged groups (women, youth, disabled persons, and indigenous). Moreover, MIDEPLAN also kept the project planning and evaluation functions that ODEPLAN had conducted. Article 2 of Law 18.989 assigned MIDEPLAN with the following functions:

a. Conduct studies, analysis and proposals relating to national development and hear proposals from different stakeholders

b. Submit annually to the President of the Republic the public sector goals and the regional investment targets in preparation for the budget bill.

c. Submit annually to the President of the Republic a comprehensive and integrated plan to address poverty and unemployment problems

d. Coordinate with the Budget office of the Ministry of Finance the annual budget projects that ministries, municipalities, decentralized institutions and state enterprises must prepare.

e. Collaborate with the Ministries of Interior and Finance in preparing the draft budget of National Fund for Regional Development

f. Establish the criteria for economic evaluation and social investment projects financed directly or indirectly by the State

\footnotetext{
${ }^{121}$ Intervention of Sergio Molina in Congress.

${ }^{122}$ Congress debate, sesión 10, June 20, 1990.
} 
g. Propose and provide technical advice to mayors for formulating and implementing policies, plans, development programs, and regional investment budgets

h. Carry out research and evaluations of public policy

Law 18.989 proposed an internal organization comprising five divisions: the Administrative, Legal, Planning, Studies and Investment, Social, and Regional Planning divisions.

The Division of Planning, Studies and Investment is responsible for managing and evaluating public investment and coordinating the elaboration of national budget, with the Ministry of Finance. The Social Division is in charge of studying the situation of vulnerable social groups, as well as designing instruments and public policies targeting this population. The Planning Regional Division is accountable for decentralization and strengthening local institutions.

Aylwin's government also linked several organizations in charge of social issues to MIDEPLAN. This was the case for the Fondo de Solidaridad e Inversión Social (FOSIS), the Instituto Nacional de Juventud (INJ), the Corporación Nacional Indígena (CONADI) and the Fondo Nacional de Discapacidad (FONADIS). Therefore, besides its planning tasks, MIDEPLAN also took over functions related to social policies. Figure 4 depicts the organizational chart during the 1990s.

\section{Figure 4}

\section{Organizational Chart: MIDEPLAN, 1990s}

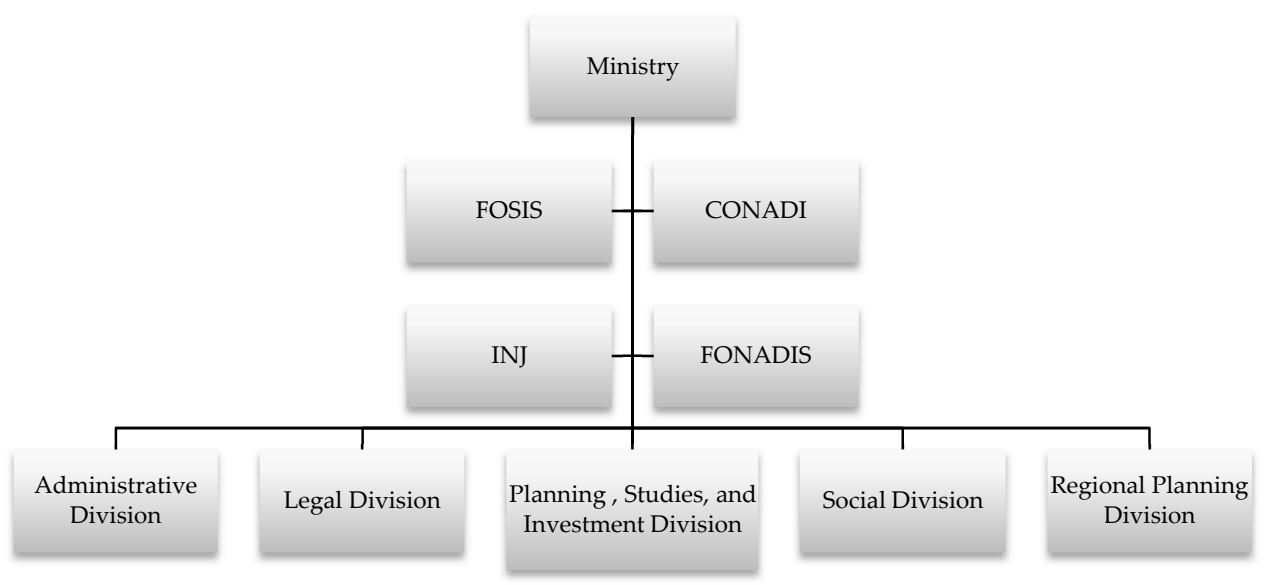

Source: Luis B Mejía, 2014 
By mid-1990, MIDEPLAN faced an institutional crisis. The functions that the agency had developed over the last twenty years had become blurred, while new features related to the coordination of social policy had not begun to materialize. In practice, the government commissioned the development of economic policy to the Ministry of Finance, unaware of the legal mandate that the planning agency had in this field, and the public policy coordination to the General Secretary of the Presidency (Segpres). The economic policy making, was by now in charge of the Ministry of Finance and the Central Bank.

Senator Carlos Cantero claimed that the planning organization had ceased to be the national governing body for planning and economic policy, becoming an abstract agency without a defined role.

What has happened is that MIDEPLAN does not have a defined role. It was born as a hybrid, product of a genetic alteration: planner, evaluator and executor at the same time, with multiple areas and functions, but without effective power of decision. Probably for the same reasons, its director has had little political influence in the cabinet. ${ }^{123}$

A former Minister of Labor also commented:

It was curious because they elevated the status of MIDEPLAN to that of Ministry but instead the organization lost its positioning. In reality there was not one good Minister of Planning, nobody knew well what they were doing. Actually, MIDEPLAN turned out quite irrelevant. The organization was taking over a lot of topics that nobody wanted to assume. ${ }^{124}$

Amid questions about its effectiveness, the agency suffered constant changes in its director (four changes during 1994-1999). At the moment of his resignation from MIDEPLAN, one of these ministers told reporters that the Ministry of Planning did not have appropriate resources or political support to address the long list of tasks allotted to the agency. The situation in MIDEPLAN became complicated to the point that President Frei Ruiz-Tagle (1994-2000) announced the need to end the organization. As a former ILPES director said:

${ }^{123}$ Cantero, Carlos (1999) “¿Quo Vadis MIDEPLAN?”

${ }^{124}$ Author's interview, former Deputy and Ministry of Labor. Santiago de Chile, June 28, 2011. 
Here in Chile President Frei downgraded MIDEPLAN. Here we have a saying "cajón de sastre" - the confectioner's drawer where one throws away all little pieces that are spare. MIDEPLAN during Frei's government started to transform into a confectioners drawer. They included in the agency topics of indigenous populations, disabled, gender issues, this and that. At some point they even talked about MIDEPLAN addressing the social history, what is that? ${ }^{125}$

During this time, several editorials and opinion columns appeared in the newspaper El Mercurio, a conservative Chilean newspaper, criticizing the situation that the agency was facing.

ODEPLAN was independent; the agency only answered to the head of state, but worked closely with the rest of the cabinet. There was unity of thought, coherence in the government team. The creation of MIDEPLAN was harmful and it should become again a planning office linked to the presidency of the republic (...) A paradox: the planning and its institution reach its zenith in Chile during the period of a right-wing authoritarian rule, and its annihilated during a left-center democratic regime (...) We come to the conclusion that there is not a problem of staff, the point is that the law gives MIDEPLAN an immense amount of tasks that are clearly not met for several reasons. To put it bluntly, MIDEPLAN is a useless ministry in current conditions. ${ }^{126}$

With the arrival of Ricardo Lagos (2000-2006) to the presidency, the idea of abolishing MIDEPLAN was reverted and instead efforts were applied to make it more adequate for social policy making. For example, to balance out economists' prevalence over the planning agency, professionals in social sciences and other careers started to be hired as part of the organization's staff. Among the six agency directors from 2000 to 2010, there was one lawyer, one social researcher, two sociologists and one physical education trainer. In the same direction, Clarisa Hardy, Minister of Planning in 2007, decided to end the agency's 30-year contract with the Catholic University to train public officials on social project evaluation. She considered it inappropriate for this university to continue providing this course when other universities were also capable of doing so. Moreover, she was against the economic focus that the Catholic University placed on the social

\footnotetext{
${ }^{125}$ Author's interview, former ILPES director, Santiago de Chile, June 23, 2011.

${ }^{126}$ El Mercurio (1998) "Crónica de una Muerte Planificada." Santiago de Chile: martes 26 de mayo
} 
evaluation of projects. Ernesto Fontaine, director of the program, opposed this decision, as it seemed out of place and ideologically biased. ${ }^{127}$

During the 2000s, MIDEPLAN focused on coordinating social policies, ensuring the appropriate use of investment planning projects through managing the National Investment System and defining national guidelines for regional development. However, the agency's influence over the Chilean public sector largely diminished compared with the role that ODEPLAN had played throughout the 1970s and 1980s.

In 2010, after twenty years of governments from the center-left coalition, a centerright candidate won the presidential elections. President Sebastian Piñera (National Renewal Party) appointed Felipe Kast, son of the former director of ODEPLAN Miguel Kast, as Planning Minister. In an interview prior to his appointment as a minister, Kast had spoken about his thoughts concerning MIDEPLAN:

I would change MIDEPLAN, nobody remembers MIDEPLAN's ministers, unlike the Treasury ministers. I would make the agency a national priority. The social policy that MIDEPLAN manages is precarious; what the agency does is to distribute and channel these social programs that are not even well thought out in the first place. Piñera's proposal to transform MIDEPLAN into a mega-ministry is so powerful because what Chile needs is a coherent and integrated social policy. Today according to some studies, MIDEPLAN is only responsible for $4 \%$ of social spending. This type of ministry cannot assume social policy as a political tool. ${ }^{128}$

In May 2011, Minister Felipe Kast presented a bill to Congress requesting the transformation of MIDEPLAN into a new Ministry of Social Protection. The project was unanimously approved at its first debate and today continues its legislative process.

The planning body in this later period drifted away from its preceding trajectory. Not only was the agency's formal structure changed to that of a Ministry but also, its economic functions replaced by social ones, and the bulk of technical staff with a background in economics replaced by professionals in social sciences' careers. The long-dated training agreement between Universidad Católica and Mideplan

\footnotetext{
127 El Mercurio (2007) "Polémica por decisión de Mideplan de terminar programa que dictaba la UC desde 1976". Santiago de Chile: viernes 8 de junio.

${ }^{128}$ El Mercurio, interview with Felipe Kast. Saturday July 25, 2009.
} 
was also ended. This departure in the agency's trajectory was preceded by a critical juncture, namely the return to Government of a center-left coalition after almost twenty years of military regime, coinciding with the theoretical observable manifestations of the cultural-institutional perspective. The internal structure of MIDEPLAN was also transformed, for example with the inclusion of a Social Division to respond to the new social tasks assigned to the organization as the causal mechanism of the task-specific perspective suggests. Transformations of the agency in this period were initiated by Presidential initiative. The center-left coalition sought to tone down the previous planning agency, sending a message that its economic policy radically differed from the previous one, with social issues put upfront

\subsection{Conclusion}

In light of the theories of organizational change presented in Chapter 3, the case of Chile's planning agency is an interesting one because empirical accounts of punctual historical moments of the agency's transformation credit the operation, with all its composing parts, of all four causal mechanisms. For the period of creation of CORFO, data show the formation of coalitions around the agency as well as explicit efforts to isolate the agency from its opponents as the structuralinstrumental theory predicts. Regarding the cultural-institutional approach, this research finds evidence that after a critical juncture episode (coup d'état in 1973) the planning body changed its trajectory, from structuralist-oriented policies to neoliberal policies. The before-and after critical juncture situation of the planning agency shows distinct socialization and lock-in mechanisms. In the structuralist period, the agency recruited its personnel from the Universidad de Chile (politically inclined to the left) while under the neoliberal period recruitment took place among professionals from Universidad Católica (politically inclined to the right) and among political affiliates of the gremialistas. Transformations of the agency during this same period can also be interpreted under the lens of the environmental perspective given that the neoliberal policies promoted by the University of Chicago permeated Chile's governmental structures. Finally, the transformation of ODEPLAN into MIDEPLAN provides a positive case of operation of the causalmechanism of the task specific perspective given that a change in the prevailing economic development priorities shifted the agency's focus toward social policy, adapting its internal divisions and personnel to this need.

Notwithstanding, looking at the entire sixty years of trajectory, none of these theories on their own provide a sufficient explanation of the continuous transformation of the planning agency. A common denominator alongside these alternative explanations that shows up consistently throughout the history of the 
organization is the role that Presidents, de facto or democratically elected, played in shaping the organizational structure. 


\section{Chapter 8: Colombia case study}

\subsection{The genesis and evolution of the planning agency}

Colombia followed a policy of import substitution industrialization since the 1930s which started as a response to the collapse of international market prices of coffee and the reduction of external credit. This period coincided with the government's establishment of mechanisms of macroeconomic regulation such as import duties to all trade competing with domestic goods, the adoption of an exchange rate control and credit market intervention (Ocampo, 1987). These measures rapidly made domestic production more profitable compared to imported manufactured goods, which became more expensive. Consequently, industry expanded, especially manufacture, with an average annual growth rate of 10.8 percent between 1931 and 1939 (Hartlyn, 1988). These figures sharply contrasted with the country's overall economic growth, which averaged 3.3 percent during the same period (Ocampo, 1987).

In contrast with other Latin American countries where industrial policy discriminated against agriculture in favor of non-traditional basic industries, in Colombia there was no rupture between industrialists and export-oriented landowners during these early years of industrialization (Hartlyn, 1988). In fact, according to Palacios (1983), none of the liberal Presidents of the 1930s developed a conscious industrial policy.

During the 1940s and 1950s, the government strengthened the strategy of import substitution industrialization through the establishment of additional tariff barriers and other restrictions on imports such as licenses and quotas. The government started channeling more resources to the industry and even directly investing in certain businesses. For the first time, the government began substituting the imports of agricultural goods, and especially cotton, in addition to industrial goods. This contributed to the modernization of agriculture and the development of policy instruments designed to promote the rural sector.

These decades were accompanied by an institutional and organizational transformation that supported the establishment of the inward-economic growth strategy. In 1945, a constitutional reform established that Congress should have plans and programs to guide decisions on public investment, with public organizations such as the Development Institute created to make direct investments in the industrial sector. Agencies like the Council of National Economy, the National Economic Board, the Committee of Financial Experts and the Economic Development Committee were granted economic policy making and planning responsibilities. In practice, these tasks were barely exercised; instead, the 
role of these bodies was limited to listening to the opinions of businessmen and politicians (Rivera, 1976; Urrutia, 1988).

This situation began to change during the 1950s. The government of Laureano Gómez (1950-1953) in an attempt to improve the planning instruments of the country requested the World Bank to conduct an assessment mission and provide specific recommendations. The World Bank mission directed by Lauchlin Currie ${ }^{129}$ delivered a policy document "Bases de un Programa de Fomento para Colombia" with recommendations to accelerate urban growth, conduct an agrarian reform and accelerate industrialization. Among other things, the Mission recommended the establishment of several advisory bodies to the President what resulted in the creation of the Planning Office of the Presidency in 1951. This office replaced the Economic Development Committee as well as the Council of National Economy (Rivera, 1976). From an early stage, this planning body started to include the management of external aid and foreign credit as part of its organizational core functions, ${ }^{130}$ in a role that intensified in later planning institutions. In 1952, the government transformed the Planning Office of the Presidency into the National Council of Economic Planning. This Council was comprised of three members chosen by the President and advised by international experts appointed by decree, such as Lauchlin Currie, George Kalmanoff, Jacques Torfs and Albert Hirschman (Caballero and Vélez, 2008).

In July 1953, General Gustavo Rojas (1953-1957) deposed President Laureano Gomez in a coup d'état. General Rojas was thrust into power by a segment of the Conservative Party, the military and with the approval of the Liberal party. During the military regime, all planning activities were suspended for almost a year. In 1954, the military junta reorganized the planning organizations through the abolition of the National Council of Economic Planning and the creation of the National Directory of Fiscal and National Planning, an entity that had no executive functions. Ten months later, the National Directory was converted into the National Planning Committee.

\footnotetext{
${ }^{129}$ Lauchlin Currie was a Canadian-born U.S economist who directed a World Bank mission to Colombia from 1949 to 1953. Currie was chief economist at the Colombian National Planning Department from 1971 to 1981.

130 According to Rivera, "six functions were assigned to the Presidential planning office. Three were related to external influences (foreign credit, technical assistance, and implementation of World Bank recommendations), two referred to research activities, and one emphasized the office's nature as a technical body at the service of the President". Rivera Ortiz, Angel Israel (1976) The Politics of Development Planning in Colombia. New York: A PHD dissertation submitted to the Faculty of the Graduate School of State University of New York.
} 


\subsection{The Department of Planning and Technical Services}

In 1957, democracy was reinstituted in Colombia under a new institutional arrangement known as the National Front. According to Archer and Shugart (1997), the political pact under the National Front was designed to bring to an end conflicts between the two dominant political parties (liberals and conservatives), which had led to civil war and subsequently the four-year military dictatorship of General Rojas. Hartlyn (1988, p.3) described the National Front "as an elite response to a perceived crisis stemming from the fear of exclusion from power by the military government, potentially revolutionary violence in the countryside and economic stagnation". The main stipulations of the National Front involved: (i) alternating the Presidency between both parties, every four years; (ii) sharing governmental responsibilities by having equal representation of both parties in Congress, cabinet and government offices, Supreme Court positions, departmental assemblies and municipal councils; and (iii) demanding a two-thirds majority on non-procedural decisions in all elective bodies (Jaramillo et al, 1999).

This political pact was supported by all factions of the ruling class, industrialists, bankers and merchants (Hartlyn, 1988). Furthermore, the National Front was legitimized through a referendum in which Colombian citizens were asked about their acceptance of the political agreement. Following its approval on December 1, 1957, the political structure of the National Front was set for a period of 16 years (1958-1974). Likewise, the rules to run within parties were also established. Another tacit characteristic of the National Front was that industrialists benefited from long-term privileged access to the policy making process while urban workers and peasantry had little or no participation (Juárez, 1993).

Elections for the first period of the National Front were held in 1958, with Alberto Lleras Camargo (1958-1962) from the Liberal Party assuming the Presidential office. Llera's government continued with the development strategy from earlier decades, expanding support to the industrial sector. Exchange rate controls were implemented, with new tariffs, quotas and licensing designed to shelter the industrial sector from foreign competition (Ocampo, 1987).

Influenced by ECLA and actually consulted with Raul Prebish ${ }^{131}$, President Lleras proposed the creation of a planning body to strengthen the government capacity in economic policy making. In this context, through executive initiative, Congress

\footnotetext{
${ }^{131}$ Based on author's interview, former board of directors of the Central Bank. September 9, 2010. See also Caballero Argaez, Carlos (2008) “Origenes y Antecedentes de la Planeación en Colombia." In: Cincuenta Años Departamento Nacional de Planeación. Bogotá: Departamento Nacional de Planeación.
} 
ruled Law 19 of 1958 on administrative reform. Among other provisions, Law 19 created the Department of Planning and Technical Services as a central planning office. According to a former National Planning Department director:

\begin{abstract}
Alberto Lleras had been working in Washington, and by that time the group known as "the wise" had been already created with the intention of coordinating policy in Latin America. The point is that Lleras is who brings the idea of planning; he brought and proposed the project. And I understand that President Lleras worked closely on the planning project with Carlos Lleras (who was later President of Colombia in 1966). Carlos Lleras comes from the influence of ECLA, he really believed in the idea of planning. So the creation of the planning office dates back to these two people who were acquainted with the idea of the state intervening in the economy (...); and I really think that their idea of creating that sort of organization was to contribute to a good government, to do things right, to allocate public resources well. ${ }^{132}$
\end{abstract}

The planning body was designed as an administrative department of the national government and was directly responsible to the President. According to Augusto Cano (1972), Law 19 of 1958 marked the beginning of a more stable planning agency. For the first time, this entity assumed the technical nature of Administrative Department, which remains to date. The new planning office was assigned with functions related to the preparation of four-year public investment programs, the elaboration of development plans, facilitating the establishment of planning offices inside ministries and other public bodies and the presentation of periodic reports to the President on the execution of governmental plans. Decree 0239 of 1959 further specified the functions, internal organization and type of personnel of the planning department (Rivera. 1976). Figure 5 below shows the internal structure of the planning body.

Law 19 provided that the chief executive of the Department of Planning and Technical Services should be appointed by the President; moreover, it granted him the authority to require from other public agencies data and information necessary for the performance of the duties of the planning body (Morcillo, 2002). According to Law 19, the head of the Department of Planning and Technical Services also should act as Executive Secretary of the National Council of Economic Policy and Planning.

${ }^{132}$ Author's interview, former director of the National Planning Department. June 29, 2010. 


\section{Figure 5}

\section{Organizational Chart: Department of Planning and Technical Services, 1958}

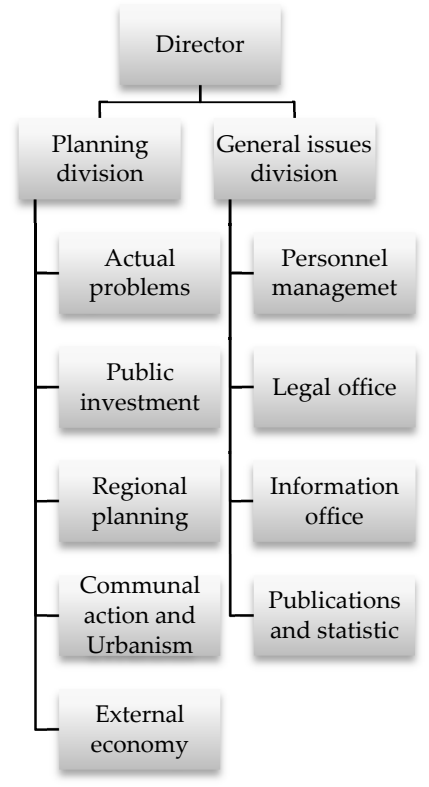

Source: Luis B Mejía, 2014

The National Council of Economic Policy and Planning was a collegial body created by Law 19 and intended as a decision making body. The Council was chaired by the President and initially comprised ministers dealing with economic affairs. However, Congress made radical changes to the Council, creating a fourman board, two members of which were appointed by the President and two directly by Congress ${ }^{133}$ (Urrutia, 1988). According to a former member of the board of directors of the Central Bank:

The attempt of Congress of being part of the planning council contributed with the ineffectiveness of this organism. The council failed to become a forum for a technical discussion of the economic policy, and transformed itself in a scenario where the political quarrel took place. In the long-run, this situation contributed to the weakening of the Planning Department. ${ }^{134}$

\footnotetext{
${ }^{133}$ One by the Senate and one by the House of Representatives.

134 Author's interview, former member of the board of directors of the Central Bank. September 9, 2010
} 
Carlos Lleras who was the direct responsible for writing the text of the original bill of Law 19 also commented on this matter: "the planning council was never conceived with members others than the Ministers and public officials who are the natural policy-makers and executors of economic policy. This structure was previously consulted with Raul Prebish and other economists that had vast experience. But in Congress the bill was changed to introduce that Council of four members, two of them named by the Senate; this never worked, it debilitated the authority of the head of the Planning Department and distanced the Ministries" (Cano, 1978: p223).

Indeed, the Planning Director soon came into conflict with the Council members. According to Cano (1972), the division of functions between councilors and the head of the planning agency was not clear, which affected the authority line with staff members from both the planning agency and the council.

These conflicts weakened the planning organization and turned into crises during the government of the Conservative President Guillermo Leon Valencia (19621966). For a nine-month period, the planning agency had no appointed Director and was thus paralyzed. The National Council of Economic Policy held only six meetings from 1963 to 1965 (Rivera 1976; Urrutia 1988).

The institutional crisis was so severe that Colombia was asked by the World Bank and the International Monetary Fund to commit itself to strengthening the planning office. I think that the real reason behind this was the urge of the international financial institutions to have one cohesive interlocutor to negotiate international credits, instead of dealing with different ministries and entities, each presenting projects for credit approvals with no prior planning. ${ }^{135}$

Additionally, the Colombian government agreed to commit to certain requirements set by the Alliance for Progress, in order to access to the development loans that the United States was granting to developing countries, among them the consolidation of a stable planning system that would allow creditors to understand the set of public investment priorities in which loan resources were to be used.

As a result, in August 1963 Congress passed Law 21 granting powers to the executive to reform public administration. Through Decree-Law 3242, issued by the Government in December 1963, intervention of Congress in planning was

135 Author's interview, former director of the National Planning Department. September 2, 2010 
eliminated by removing the figure of the four councilors. Additionally, the position of planning director was strengthened by appointing its titular as a permanent member of the National Council of Economic Policy and Planning. The ministers of Finance, Development, Agriculture and Public Works also formed part of the new Council, as well as the head of the Central Bank and the director of the National Federation of Coffee Growers. The President of Colombia continued as chairman of the council, while the technical secretariat was delegated to the Sub-Director of the planning agency.

The new organizational arrangement brought by the Decree-Law 3242 also transformed the functions of the Council and the planning agency. The role of the council was now centered on approving the National Development Plan and stipulating policy measures to implement the plan, while the planning agency retained all the technical tasks, particularly including the responsibility for defining the size and breakdown of the national investment budget. The law also provided government with the authorization to reform the rules for the budgetary process (Decree 1675, June of 1964). This decree introduced the Department of Planning as a new budget authority in charge of the investment budget, yet still subordinated to the Ministry of Finance in the final decisions of the budget preparation and execution (Hommes, 1996).

Developing the new technical tasks presented a challenge due to the lack of qualified staff in the public sector. This limitation was partially solved through two strategies (Perry, 1973). First, by using a loan from the Inter-American Development Bank to create a fund oriented to improving the salaries of qualified personnel. As part of this fund, the planning agency added the Projects Group to its structure, a specialized team responsible for drafting projects susceptible to receiving credit from multilateral financial agencies. Second, the strategy was to rely on international technical assistance, with various missions from ECLA, United Nations, World Bank, and Harvard University providing technical advice to the planning office. In particular, USAID, through Alliance for Progress, fostered the development of a technocratic, "de-partisanized" and institutionalized planning structure (Dix, 1987).

The progress made by the Colombian planning system during the first two governments of the National Front was essentially theoretical and formal. It focused on meeting the conditions required to obtain access to external aid from the United States, under the rules of Alliance for Progress. During this period, the planning agency produced the first Colombian Development Plan (Plan General de Desarrollo Económico y Social), following ECLA's blueprint. The plan was presented to the Organization of American States, in Punta del Este, Uruguay, in January 
1962. Also, with the assistance of ECLA, the planning agency produced the first ten-year development plan (Plan General Decenal de Desarrollo). These events match the observable implications, particularly conditionality loans, hypothesized by the causal mechanism of the environmental approach. This early influence on the planning body was not solely the result of external impositions but also the willingly adoption, by President Alberto Lleras Camargo who believed in planning as a way to modernize the country. The narrative accounts of this period also show that the creation of the agency and subsequent amendments were initiated by executive initiative and that the leverage of Congress in planning matters was surpassed by the President.

\subsection{The National Planning Department}

The third period of the National Front between 1966 and 1970, under Liberal President Carlos Lleras Restrepo, was marked by the shift from an import substitution industrialization strategy towards an economic strategy based on export promotion (Juárez, 1993). By 1966, the exchange rate policy had overvalued the peso and made it virtually impossible for industrials to export their products. Furthermore, the government confronted a balance of payment crisis as a result of a continued decline in coffee prices, which was the main generator of foreign currency at the time (Juárez, 1993). According to Edgar Gutierrez Castro (1983), director of the planning agency between 1966 and 1970, the solution to this financial, fiscal and exchange crisis was left to the work of the National Planning Department. Commissioned directly by President Carlos Lleras, the planning body, working closely with the Monetary Junta, designed a new framework for trade and foreign exchange (Hartlyn, 1988).

Opposing the recommendations from International Financial Institutions, the new framework for trade and foreign exchange, Decree-Law 444 of 1967, was based on three set of measures: first, the establishment of a crawling peg exchange rate in which the government made a series of small and gradual devaluations of the peso to keep up with inflation and make exports competitive; second, diversifying exports through incentives for promoting non-traditional exports; and finally, the strategy comprised some basic regulations for international financial institutions to operate in the country in harmony with the national interest.

The new exchange rate scheme successfully addressed the balance of payments problem and, together with export promotion incentives, had the effect of diversifying the country's economy. Both measures played an important role in promoting political stability and reducing the country's vulnerability to the external sector. The export promotion scheme strengthened the political system in 
the sense that a more diversified export sector rendered it more difficult for any one group to play a hegemonic role (Juárez, 1993).

President Carlos Lleras, who had previously participated in the drafting of Law 19 in 1958, giving birth to the planning agency, continued convinced of the necessity to build up a more vigorous state apparatus and rationalize the process of decision making in order to gain economic growth and development. ${ }^{136}$ Accordingly, he undertook a profound administrative reform of the public sector, bringing about the largest institutional transformation of the National Front period. On the one hand, the government promoted the creation of semi-autonomous organizations capable of facilitating the economic policy making. President Lleras set up two new agencies in charge of coordinating foreign economic relations: the Export Promotion Fund and the Foreign Trade Institute. According to Juarez (1993), both agencies were removed from congressional scrutiny and staffed with technocrats.

On the other hand, President Carlos Lleras was sure that the state needed to develop a more vigorous planning capacity. ${ }^{137}$ In this sense, Lleras was determined to produce a constitutional and administrative reform, and accordingly he elaborated a draft proposal to present to the Legislative. Lleras stated the relevance of his intended reform in his message to Congress:

In Colombia there is no real planning to which the activities of the State are connected (...) The proposed constitutional reform provides effectiveness to the planning system and exalts the principle that no expenditure can be authorized if it is not supported by resources to satisfy it (...) Essentially, a modification in the distribution of competences between the executive and legislative branches of power is proposed. ${ }^{138}$

\footnotetext{
${ }^{136}$ Based on author's interviews with Secretary for Administrative Reform under President Carlos Lleras and former mayor. April 29, 2011, and former member of the board of directors of the Central Bank and Ministry of Energy. September 9, 2010. See also Hartlyn, Jonathan (1988) The Politics of Coalition Rule in Colombia. Cambridge: Cambridge University Press.

${ }^{137}$ Based on author's interview with Secretary for Administrative Reform under President Carlos Lleras and former mayor. April 29, 2011. See also Hartlyn, Jonathan (1988) The Politics of Coalition Rule in Colombia. Cambridge: Cambridge University Press.

${ }_{138}$ Mensaje del Presidente de la República, Doctor Carlos Lleras Restrepo al Honorable Senado. In: Rivera Ortiz, Angel Israel (1976) The Politics of Development Planning in Colombia. A PHD dissertation submitted to the Faculty of the Graduate School of State University of New York.
} 
The ruling of the proposal in Congress was not easy. The proposed reform found political opposition, mainly because Lleras' measures generated resistance from politicians concerned about the rationalization of the state's decision making and the immunization of state bureaucracy from clientelist proposes (Hartlyn, 1988). Long negotiations between the legislative and the executive were necessary, with the constitutional and administrative reform finally approved in December 1968. As part of the deal to pass the constitutional reform, the legislative secured individual budgetary allocations (parliamentary grants) to be used in their constituencies. The presidential secretary for administrative reform under President Carlos Lleras commented:

The acceptance of the constitutional reform by Congress, was the output of a non-official agreement between the government and Congress around the issue of parliamentary grants. Through this figure, all Congressmen obtained budgetary resources for their political strongholds, presumably for good deeds and public works of local importance. ${ }^{139}$

At this point, while guaranteeing free enterprise and private initiative, economic planning was set as a compulsory function of the state. Consequently, the role of the executive and the legislative in the planning system was redefined, particularly with reference to public expenditures. The President was assigned the function of presenting the development plan to Congress, as well as an annual budget addressing the priorities set out in that plan. The legislative was authorized to approve or reject the executive's budget as a whole but could neither modify specific appropriations nor add new expenditures (Rivera, 1976). The constitutional reform also created a permanent commission inside Congress with the function of approving and evaluating the national development plan. According to a former director of the planning agency:

139 Author's interview with Secretary for Administrative Reform under President Carlos Lleras and former mayor. April 29, 2011. 
This Commission in reality was never formed. Congressmen could not agree on creating this Commission. And the reason is quite obvious. No Congressman has the intention of delegating into few of his colleagues, who represent a specific region, the oversight of the entire national plan. The regional breakdown of resources was at stake and it could be against the regional political fortresses of various Congressmen. Allowing few hands to have a saying on this was not going to happen. This changed much later with the Constitution of 1991 when the entire Congress, not a small commission, had to approve the National Plan. ${ }^{140}$

The constitutional and administrative reform further cut the legislative initiative through the following type of laws: (i) those establishing national budgetary organic norms; (ii) those establishing that development plans were to be implemented with the national budget; (iii) those transferring the authority to propose the creation and/or transformation of public sector agencies from the legislative to the executive; and (iv) those ruling over policies related to setting or regulating tariffs, currency exchange rates and external trade (Morcillo, 2002). According to Ocampo (1987), the constitutional reform of 1968 concentrated more power and decision making in the hands of the executive. This resulted in the President's greater involvement in issues such as monetary policy, public credit, fiscal balance, foreign trade and the organization and administration of public agencies.

Through decree 2996, the functions of the planning agency were adapted in accordance with the new dispositions of the constitutional reform. Its core functions now included: (i) setting down norms for the establishment and operation of sector-level planning offices; (ii) preparing the central government investment budget to be presented by the Ministry of Finance to Congress; (iii) organizing development plans and presenting them to the Economic Council of Economic and Social Policy; (iv) proposing economic policies; and (v) submitting reports to the President and Congress concerning the progress made in the implementation of the National Development Plan. In addition, the planning office was asked to provide formal approval on budgetary decisions (Ministries do not receive approval for their investment projects without previously justifying them to the planning agency), participate in the computation of governmental incomes, review and endorse both external and internal credit solicitations made by the government, make some decisions over tariffs and provide authorizations of all direct foreign private investments ${ }^{141}$ (Rivera, 1976). Finally, the director of the

\footnotetext{
140 Author's interview, former director of the National Planning Department. June 29, 2010.

${ }^{141}$ In turn, giving the planning office influence over industrial policy
} 
planning agency, or his representative, was appointed as board member of all major economic policy bodies and public enterprises (Urrutia, 1988).

All these new responsibilities appointed to the planning agency required highly qualified personnel, prompting Lleras to bring a whole new generation of economists and engineers with professional degrees from foreign universities to the planning agency (Urrutia, 1988). The technocracy of the planning agency became the transmitter of strategic thinking of the President and that responsible for monitoring the decisions taken in the Council of Economic and Social Policy (Caballero, 2008). In 1969, the planning agency created the document Planes $y$ Programas de Desarrollo (Development Plans and Programs), which was essentially focused on a list of projects that had already guided the governmental action and fulfilled the funding requirements of the lending agencies (Urrutia, 1988).

By 1970, Conservative President Pastrana (1970-1974) inherited the Development Plans and Programs from the Lleras government. Pastrana decided to change this plan for his own program and appointed Roberto Arenas as a new head of the planning agency. Arenas was considered a politician who did not ensure the continuity of the technical style of previous governments, which resulted in a crisis at the National Planning Department, with a massive turnover of personnel (Hartlyn, 1988). Nevertheless, Pastrana not only kept Arenas as head of the planning agency, but also asked Lauchlin Currie to return the country and advise his government on the elaboration of his own National Development Plan, the Four Strategies (Marcos, 2001).

With sixteen consecutive years of power guaranteed by the National Front agreement to a relatively homogeneous group of traditional party leaders, as well as the concentration of power in the Presidential institution, economic policy making was defined simply in technical terms and solved accordingly. The rules of the game were locked for a long period. The interests of the country's industrial elite were secured and thus debate over long-term structural economic choices was not needed. Consequently, the economic policy was centralized within the executive branch and placed under control of semi-autonomous bureaucratic institutions, such as the planning department, in order to concentrate expertise and limit clientelistic pressures for political patronage (Hartlyn, 1988; Juarez 1993).

In fact, from 1970 to date, the National Planning Department has taken over responsibility for all major programs and policies of each government. A former National Planning Department and ILPES director stated: 
Given that the National Planning Department was so good and so technical in what it did, Presidents were adding tasks to what the agency did. Indeed, Presidents saw the planning department as a government agency, let's say, preserved from the political maneuvering. The National Planning Department offered tranquility to the government for its technical work, also the planning agency seemed reliable by Congress. Hence, the design and management of major government programs were charged to the Planning Department by the Presidents, even today. Remember that DRI, the National Rehabilitation Plan, Social Action Plan all of them passed through the planning agency. ${ }^{142}$

In the same way, Luis Eduardo Rosas, former National Planning Department (1972-1974) and ILPES director (1976-2978) states:

The National Planning Department has been assigned with a number of functions in order to ensure that these functions are actually delivered. The problem is that the DNP has to deal with too many aspects. ${ }^{143}$

Also another former director the planning body particularly commented on the influence of the President over the agency:

Each period of the national planning department depends on the priorities that each incoming Government has. So when Presidents are desperate because something is not coming out as they want it, they hook it on to the DNP. So this is why the relative positioning of certain policies are very much tied to the importance that the President gives to the DNP. The planning agency is what the President wants it to be. ${ }^{144}$

Throughout the 1970s, the planning agency was restructured adding new responsibilities to the agency. The government, using a blanket authorization from Congress, enacted a new budgetary regime through Decree 294 of 1973. This regime gave the planning agency the task of allocating the investment resources, albeit subject to the budget limitations imposed by the Ministry of Finance. In 1974, President Pastrana, through Decree Law 627, attached to the National Planning Department the Regional Autonomous Corporations (agencies in charge of the

\footnotetext{
${ }^{142}$ Author's interview, Former National Planning Department and ILPES director. Bogota, April 7, 2011.

143 Rosas, Luis Eduardo (1983) "La Planificación y la Política Macroeconomica". In: La Planeación en Colombia 1958-1983. Bogotá: Departamento Nacional de Planeación.

144 Author's interview, former director of the National Planning Department and congresswoman, Bogota May 18, 2011.
} 
regional planning). President Lopez (1974-1978) commissioned to the planning body the National Food Plan, and placed the Integrated Rural Development Program (organization in control of the agricultural development and promotion) in the structural arrangement of the organization, through Decree 1268 of 1976.

In summary, from 1970 until present, the National Planning Department has taken over responsibility for the elaboration of the National Development Plan of each incoming administration. These plans departed from the traditional structure of macroeconomic and project-level planning, typical of previous 1970s plans, introducing a more policy-oriented format in their presentation. Each plan is printed as a book and made available to the public. Table 11 below depicts the National Development Plans of the last eleven administrations.

Table 11

Colombian National Development Plans

\begin{tabular}{|c|c|c|c|}
\hline $\begin{array}{c}\text { Presidential } \\
\text { period }\end{array}$ & President & $\begin{array}{c}\text { National } \\
\text { Development Plan }\end{array}$ & Main policy lines \\
\hline 1970-1974 & Misael Pastrana & The Four Strategies & $\begin{array}{l}\text { Stimulating urban } \\
\text { housing construction }\end{array}$ \\
\hline 1974-1978 & Alfonso Lopez & To Close the Gap & $\begin{array}{l}\text { Rural sector } \\
\text { modernization }\end{array}$ \\
\hline 1978-1982 & Julio Cesar Turbay & $\begin{array}{l}\text { National } \\
\text { Integration }\end{array}$ & $\begin{array}{l}\text { Public works } \\
\text { expenditure }\end{array}$ \\
\hline 1982-1986 & Belisario Betancur & $\begin{array}{ll}\text { Change } & \text { with } \\
\text { Equity } & \\
\end{array}$ & Decentralization \\
\hline 1986-1990 & Virgilio Barco & Social Economy & $\begin{array}{l}\text { Social changes through } \\
\text { state intervention }\end{array}$ \\
\hline 1990-1994 & Cesar Gaviria & $\begin{array}{l}\text { The Peaceful } \\
\text { Revolution }\end{array}$ & $\begin{array}{l}\text { Institutional } \\
\text { transformation and } \\
\text { economic liberalization }\end{array}$ \\
\hline 1994-1998 & Ernesto Samper & The Social Jump & Social policy \\
\hline 1999-2002 & Andres Pastrana & $\begin{array}{l}\text { Change to Build } \\
\text { Peace }\end{array}$ & $\begin{array}{l}\text { Rebuilding social } \\
\text { networks }\end{array}$ \\
\hline 2002-2006 & Alvaro Uribe & $\begin{array}{l}\text { Towards a Social } \\
\text { State }\end{array}$ & Security \\
\hline 2006-2010 & Alvaro Uribe & $\begin{array}{l}\text { Social State: } \\
\text { Development for } \\
\text { All }\end{array}$ & $\begin{array}{l}\text { Security and regaining } \\
\text { investor's confidence }\end{array}$ \\
\hline $\begin{array}{l}\text { 2010- } \\
\text { present }\end{array}$ & $\begin{array}{l}\text { Juan } \\
\text { Santos }\end{array}$ & National Unity & \\
\hline
\end{tabular}

Source: Luis B Mejía, 2014 
During the 1980s, the economic and debt crises that affected other Latin American Countries were not so severe in Colombia. The country's economic growth decelerated from an average of $5 \%$ to $2.4 \%$, unemployment hit $14 \%$ in 1985 and inflation rose, yet it did not imply an economic recession that other countries of the region were experiencing. Unlike others, Colombia was able to renegotiate its external debt and did not interrupt payments. Throughout this period, the government implemented adjustment policies that helped mitigate external and internal imbalances. Although such adjustments and financial constraints mainly called for attention to short-term problems, the National Planning Department was at the forefront of economic policy design along with the Ministry of Finance and the Central Bank. The government sharpened its technical skills for budget management, macroeconomic and public financial programming and coordination.

According to Hommes (1996), the repeated visits of the IMF monitoring missions rendered it necessary for the government to train and maintain technical staff capable of producing and understanding the data required by the IMF missions on a regular basis. Initially, the Central Bank had the technology, but after several missions, these technical skills were diffused to the Ministry of Finance and to the National Planning Department.145 The continuous implementation of the international financial organization programs helped to strengthen the position of the National Planning Department experts, who in fact became the main interlocutors of these institutions (van Dijck, 1988). In this context, a former director of the planning organization states:

Beginning in 1974 the government of Colombia gained access to international financial bonds. So basically, the IMF and World Bank stopped being the main financial creditors for the country which coincides with a lower influence of these organizations in the planning process. But, in 1983 with the debt crisis, private sector financing becomes harder and once again the IMF and other IFIs gain leverage and they use the planning agency as the technical guaranty for their loans. ${ }^{146}$

The National Planning Department managed to catch the attention of a large number of recent graduate professionals to work for the agency. To enroll these young people, the planning office created a scholarship program offering employees the possibility of carrying out post-graduate studies abroad. The agreement was that the scholar had to return to work for the government for twice the amount of time spent abroad (Caballero, 2008). Some of these professionals

\footnotetext{
${ }^{145}$ Hommes, Rudolf (1996) "Evolution and Rationality of Budget Institutions in Colombia". Inter-American Development Bank, Working Papers.

${ }^{146}$ Author's interview, former director of the National Planning Department. June 29, 2010.
} 
were successful, gained recognition and managed to insert themselves and rotate in top-level positions of economic policy-making bodies, think tanks, IFIs and universities (Palacios, 2001). A former DNP top official commented:

It is quite obvious, you can check out some of the directors of the DNP, almost all of them are from Universidad de los Andes, and spent time abroad. And you see that these same persons occupied high positions in the DNP, the Central Bank, the Ministry of Finance and Fedesarrollo rotating from one place to the next. It is a closed group, cohesive and shares more or less the same economic ideology. ${ }^{147}$

In 1986, President Belisario Betancur (1982-1986) commissioned the definition and administration of the National Plan of Rehabilitation to the National Planning Department. This plan was intended to guide state action to areas of the country affected by violence. The National Plan of Rehabilitation was inherited by President Virgilio Barco (1986-1990), who modified it in order to include all people affected by poverty. Under the Barco presidency, the administration of the National Plan of Rehabilitation was assigned to the Presidential Council for Standardization and Rehabilitation. This presidential Council had the cooperation of the National Planning Department.

Using a blanket authorization from Congress, President Barco enacted a new budgetary regime through Law 38 of 1989. This regime gave the planning agency the task of allocating the investment resources. Among other things, the new law mandated the creation, inside of the planning agency, of the National Investment Project Bank. Within that bank, all investment projects that were to be financed with resources from the national budget had to be registered and pass a socio-economic (technical) valuation. In early-1990, President Virgilio Barco initiated a series of changes in the development strategy to increase competitiveness, strengthen the export sector, and stimulate a productive restructuring in what were the first steps of Colombia's shift toward a more open political and economic system.

The period between 1968 and 1990 represents the golden age of the planning agency, both in terms of its hierarchy vis a vis other public sector organizations, but also because of the technical reliance it offered. The tracing of empirical accounts for this period allow observing some of the elements hypothesized by the causal mechanism of the alternative theories of organizational change. From the cultural perspective, the Constitution of 1968 marks the beginning of a rather stable institutional trajectory that reproduces itself through the recruitment of technical

${ }_{147}$ Author's interview, former top official at the National Planning Department. November 19, 2010. 
personnel from among a close network of professionals. From a task-specific perspective it is noticeable that the DNP learned how to do its tasks, it became a genuine budgetary and economic policy making institution trusted by the President, Congress, scholars, and foreign advisors. In an atmosphere that lacked a clear differentiation between the main political parties and given the rather stable macroeconomic conditions, Presidents exerted an endogenous source of change for the planning body as the agency's tasks were tailored to respond to the specific development plans that each incoming President launched.

The year 1991 marked a turning point in Colombia's history, with the adoption of a new Constitution that replaced the preceding 105 year-old Political Constitution. The 1991 Constitution deepened the decentralization process, encouraged a wider political participation and protection of civil rights. The Constitution introduced changes that further increased the power of the executive in detriment of the legislative, particularly in the extent of involvement of Congress in the planning and budgetary process. For example, the executive reserved the right to enact by decree the appropriations Law in case Congress did not approve the bill by the deadline. In addition, the Constitution lifted the importance of planning by declaring the National Development Plan and the National Planning Department as a tool and central player in the economic and social policy making. ${ }^{148}$ In the economic realm, the Constitutional reform focused on trade, labor and financial markets liberalization, as well as public enterprises privatization.

The design and implementation of these economic reforms was assigned by the President Cesar Gaviria (1990-1994) to the National Planning Department. As José Antonio Ocampo, former National Planning Department Director, stated: "President Gaviria had the good sense to invite, to at least one debate, the Ministers of Development and Agriculture, but basically the process of economic

\footnotetext{
148 This Constitutional provision was developed by Law 152 of 1994 that establishes the procedures and mechanisms (organic rules) for the development, adoption, implementation, monitoring and evaluation of national development plans and regulates planning aspects. Among other things, this law determines that the National Development Plan of each administration must set the economic and social policies as well as public expenditures to be followed during the length of the presidential term. It mandates that the National Development Plan is submitted for consultation of different groups of society, and approved by Congress. During each presidential term, all public expenditure must be framed by its respective National Development Plan; finally Law 152 stipulates that the National Planning Department is responsible for coordinating the development and implementation of the National Development Plan.
} 
opening was conducted by the National Planning Department". ${ }^{149}$ President Gaviria relied on the technical capacity and expertise of planning officials to progress the proposed reforms. ${ }^{150}$

Once again, the internal organization of the planning agency was restructured to respond to the new constitutional functions, as well as the economic policies contained in President's Gaviria National Development Plan. Decree 2167 of 1992 added new Units to the organization, namely the Territorial Development and Business Development units. Moreover, with the support of the World Bank, the planning agency launched the National Evaluation System of Public Sector Performance (SYNERGY). Figure 6 presents the organizational chart of the National Planning Department that remains current to date. According to a former planning director:

The national planning department has gradually adjusted to the country's changes. For example, before when the economy was closed, the agency was a very different thing from what it is today. There was an office approving foreign direct investment, there was a committee establishing tariffs, etc. It reflected what the country was, a closed country. During the 90s the country opened up, both in economic and democratic terms and the planning agency changed alongside. For example, to better respond to the long internal armed confrontation, the government created inside the planning body the Justice and Security unit in charge of designing, together with the Ministry of Defense, the budgetary strategy for facing conflict. ${ }^{151}$

By the end of the 1990s, Colombia experienced economic recession, with negative economic growth occurring for the first time since the great depression of the 1930s (Lora, 2010). Besides, the scale and intensity of the Colombian internal conflict had increased, contributing to the steady decline of the economy and the deterioration of the social conditions. President Andres Pastrana (1998-2002) relied on the planning agency not only for the design of the Plan Colombia, ${ }^{152}$ but also the social

\footnotetext{
149 Interview with Jose Antonio Ocampo. In: Urrutia, Miguel and Carlos Caballero Argaez, (2008) Cincuenta Años Departamento Nacional de Planeación. Bogotá: Departamento Nacional de Planeación

${ }^{150}$ Author's interview, former National Planning Department and ILPES director, Bogota, April 7, 2011.

151 Author's interview, former director National Planning Department. Bogotá April 26, 2011.

152 Plan Colombia was focused on strengthening the military capacity of the Colombian Armed Forces and was partially financed by USAID.
} 
safety net programs seeking to mitigate the impact of economic shocks on the poorest segments of the population. The National Planning Department provided President Pastrana with the technical tools to focus social aid toward specific vulnerable populations, as well as the design of social policy projects to confront the economic situation. 153

\section{Figure 6}

\section{Organizational Chart: DNP, 1992-Present}

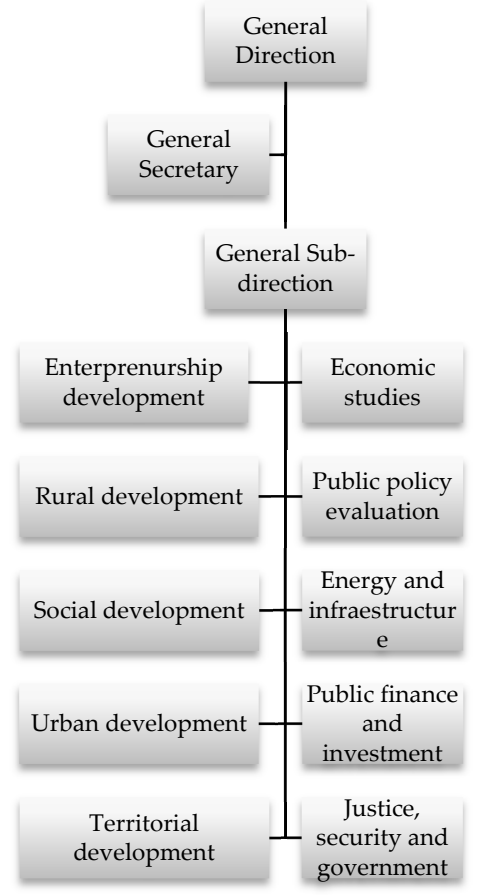

Source: Luis B Mejía, 2014

In 2002, the elected President Alvaro Uribe (2002-2006 and 2006-2010) expressed his intention to quickly address the problem of violence in the country. His administration was characterized by an intensified struggle against the illegal groups and drug trafficking under a government program called democratic security policy. With Uribe's personal style of government, he was highly involved in each and every detail of governing. The President himself took over technical issues in various policy areas, directly subtracting decision making authority from

${ }^{153}$ Interview with Jaime Eduardo Ruiz Llano. In: Urrutia, Miguel and Carlos Caballero Argaez, (2008) Cincuenta Años Departamento Nacional de Planeación. Bogotá: Departamento Nacional de Planeación 
technical organizations, and especially the Planning agency. ${ }^{154}$ The newspaper $E l$ Espectador presented the situation as follows:

Any evaluation of the recent activities by the National Planning Department has to conclude that this has been one of the institutions most affected by the presidential re-election and the excessive personalization of power. The way to decision making of President Uribe, impulsive, sometimes improvised, with certain contempt for studies and the analysis of experts, has become a severe blow to the National Planning technocracy. ${ }^{155}$

Semana magazine also acknowledged the situation, stating in a 2009 editorial:

In the past, the National Planning Department was seen as a kind of supra-ministry within the orbit of the purely technical. It would be a concern for the country to now relegate the planning agency to the backdoor. The debate is certainly not new. It has to do with the style of the current government in which the Presidential figure is very strong. Unlike other Presidents, President Alvaro Uribe takes active part in macro and micro issues of state, somehow downplaying everything else, especially the technicians. ${ }^{156}$

Several analysts addressed this same issue and expressed concern over the fate of the planning agency. They thought that the entity was losing its technical prominence and leadership among government institutions during Uribe's government. For Juan Carlos Echeverry, director of the DNP during Pastrana's administration, "President Uribe had given ministers a free hand and instead hindered the National Planning Department, which is the entity that uses technical criteria for the design of long-term public policies"157. The same opinion was provided by Alejandro Gaviria, deputy director of Planning during the first years of Uribe's administration and currently Ministry of Health. He believes that "there was a very obvious clash between some ministers and the Planning Department [...] they were 'untouchable persons' within the cabinet and in that circumstance the planning department often lost the battles". ${ }^{158}$

\footnotetext{
154 Author's interview, former Sub-Director National Planning Department. Bogotá, March 3, 2011. See also Semana (2009) "Al Banquillo". Bogotá, February 28.

${ }^{155}$ El Espectador (2008) "los Cincuenta Años del DNP”. Bogotá: El Espectador, December 12. 156 Semana (2009) "Al Banquillo". Bogotá, February 28. 157 Semana (2009) “Al Banquillo”. Bogotá, February 28. 158 Ibid
} 
However, this does not mean that the planning body was not useful for the President. In fact, President Uribe used the planning agency to justify his decisions, under either technical or political grounds. As a former deputy director of the agency commented "President Uribe utilized the planning body's services when it implied that political decisions of his pursuit could be successfully justified based upon planning and technical analysis. However, when the support of planning directives implied evident political risks, the National Planning Department was bypassed in the decision making process". ${ }^{159}$

This situation has not changed under the administration of President Juan Manuel Santos (2010-Current) who once in office undertook and administrative reform through which several independent agencies were attached to other ministries, many of them duplicating the functions of the NDP. The planning body remains with its same formal structure but its technical grandeur of the past somewhat diminished.

Since the Constitutional reform of 1991 to date, two elements hypothesized by the alternative theories of institutional change are observed throughout this period. First, as the task-specific approach predicts the National Planning Department undertook new functions and tasks to respond to the broader political participation and decentralization commanded by the Constitution, as well to implement measures tuned with the open-market model promoted by President Gaviria. Second, empirical evidence once again provides support to the idea that an important source of endogenous transformation of the agency comes from the active or passive position that Presidents take vis a vis the organization, directly influencing its course of action.

\subsection{Conclusion}

Colombia's central planning office trajectory is rather stable. With few exceptions, its transformations have been influenced from both within the organization itself and by its close connection to the President's office. The planning body has not experienced abrupt changes in the structure and positioning of the agency within the hierarchy of the public sector, nor extreme fluctuations of the agency's prevalence.

The genesis of the planning agency in Colombia was not alien to the influence of the international actors such as ECLA, Harvard University and the World Bank, as the environmental approach would predict. These organizations contributed to the

159 Author's interview, former Deputy Director of the National Planning Department. Bogotá, March 3, 2011. 
initial configuration, staffing and financing of the agency. However, by 1968 when the agency was still young, President Carlos Lleras, by his very own genuine conviction in planning as a modern tool for policy development and coordination, greatly strengthened the agency, placing it at the center of economic policy decision making. Reinforced by various socialization mechanisms among an elite network of economists that shared common training, the agency attained technical recognition and inserted into a stable trajectory, much like the cultural institutional approach predicts. Transformations of the agency from this point onwards have gradually emerged from the incorporation of new tasks to respond to shifting conditions in the political and economic environments of the country, and most importantly induced by the President, with each incoming government using the agency's resources to design and implement their specific government priorities or as in more recent years, using the agency as a shield to bypass difficult political decisions. Without exception, all amendments to the functions of the National Planning Department have been the result of legislative initiative of the President or through direct executive decrees. 


\section{Part III. Comparative Perspectives and Conclusions}




\section{Chapter 9: The tale of four trajectories of organizational change}

After having presented the historical accounts of the transformations and evolution of the central planning agencies in the four case studies, this Chapter summarizes for each country, and compares among them, the research's main findings in terms of the plausible explanations to account for the agency's transformation. The Chapter starts by identifying similarities and differences encountered in the four countries. It then presents a summary timeline of each country's planning agency highlighting the evidence in place to support or reject the theories of organizational change introduced in Chapter 3. Finally, the Chapter exposes the shortfalls found in the external explanations of change, to then conclude that while all these explanations are necessary to elucidate certain historical moments of transformation, they are insufficient to explain sixty years of organizational change.

\subsection{Similarities and differences among case studies}

In light of the four case studies, this section presents the core similarities and differences in the historical trajectories of change of the central planning agencies of Argentina, Ecuador, Chile and Colombia.

The research compares four countries Argentina, Ecuador, Chile and Colombia that historically differ in the trajectories and changes that their planning organizations have followed. The planning agencies of these countries came to life during the late 1950s, in a response to an inward economic growth model encouraged by the Economic Commission for Latin America (ECLA). This idea of strengthening or creating a planning body was reinforced by the Alliance for Progress, from which the four countries received economic aid. Argentina and Ecuador adopted a collegial body as the structural arrangement of their planning body, while Chile and Colombia embraced a presidential office as their preferred organizational design. The initial functions assumed by these four countries were very similar, ranging from making development plans to preparing the national accounts. However, as illustrated in Table 12, the trajectory in these functions shows variations over the last sixty years. Today, the planning agency of Chile focuses on poverty alleviation and social policy, particularly targeted at minorities and vulnerable populations; in Colombia, it continues to hold many of the initial functions but now concentrates on allocating the public investment budget; the planning agency in Argentina at present is mainly responsible for regulating sectoral policies (transportation, communications, mining, energy, sanitation, public works, housing, water and roads) and providing export licenses; and finally, Ecuador's planning agency preserves several of its initial functions, but today actively leads poverty alleviation and state modernization programs. Appendix 4 
presents in further detail the evolution in the tasks undertaken by the planning agencies in each of case studies.

Table 12

Trajectory of the initial functions of the planning agency

\begin{tabular}{|c|c|c|c|c|c|c|c|c|}
\hline & \multicolumn{4}{|c|}{$1960 \mathrm{~s}$} & \multicolumn{4}{|c|}{ Today } \\
\hline & Arg & Col & Ecu & Chi & Arg & Col & Ecu & Chi \\
\hline \multicolumn{9}{|l|}{ Development plans } \\
\hline \multicolumn{8}{|l|}{ Long-term economic policy making } & \\
\hline \multicolumn{8}{|l|}{$\begin{array}{l}\text { Advising President on economic } \\
\text { matters }\end{array}$} & \\
\hline \multicolumn{8}{|l|}{ National Accounts } & \\
\hline \multicolumn{8}{|l|}{ Economic forecasting } & \\
\hline \multicolumn{8}{|l|}{$\begin{array}{l}\text { National budget, public investment \& } \\
\text { project assessment }\end{array}$} & \\
\hline \multicolumn{9}{|l|}{ Monetary Policy coordination } \\
\hline \multicolumn{9}{|l|}{$\begin{array}{l}\text { Int. aid and technical assistance } \\
\text { coordination }\end{array}$} \\
\hline \multicolumn{8}{|l|}{ Regional development policy } & \\
\hline \multicolumn{8}{|l|}{ Regulation } & \\
\hline \multicolumn{8}{|l|}{ Sectoral policy } & \\
\hline \multicolumn{8}{|l|}{ Trade related tariffs \& licenses } & \\
\hline \multicolumn{8}{|l|}{ Eval. \& monitoring Nat. Dev. Goals } & \\
\hline \multicolumn{8}{|l|}{ Modernization of the State } & \\
\hline \multicolumn{9}{|l|}{ Descentralization } \\
\hline \multicolumn{9}{|l|}{$\begin{array}{l}\text { Poverty alleviation and } \\
\text { unemployment policy }\end{array}$} \\
\hline \multicolumn{9}{|l|}{$\begin{array}{l}\text { Conducting studies on economic and } \\
\text { social policies }\end{array}$} \\
\hline $\begin{array}{l}\text { Social dialogue for improved } \\
\text { transparency and citizen participation }\end{array}$ & & & & & & & & \\
\hline $\begin{array}{l}\text { Policies targeted at minorities and } \\
\text { vulnerable groups }\end{array}$ & & & & & & & & \\
\hline
\end{tabular}

Source: Luis B Mejía, 2014

From the political standpoint, Argentina, Ecuador, Chile and Colombia have also traversed similar critical junctures coming from the various coups d'état, the processes of transition to democracy and the constitutional reforms associated to both authoritarian and democratic governments. As Table 13 exhibits, from the 
1950s to date, the four countries have undergone periods of military rule ranging from four years in the case of Colombia to eighteen years in the case of Argentina.

Table 13

Political regime (1950-2013)

\begin{tabular}{|c|l|l|l|l|}
\hline Country & $\begin{array}{c}\text { Authoritarian } \\
\text { regime }\end{array}$ & $\begin{array}{l}\text { Duration } \\
\text { military } \\
\text { regime }\end{array}$ & $\begin{array}{l}\text { Democratic } \\
\text { regime }\end{array}$ & $\begin{array}{l}\text { Duration } \\
\text { civilian } \\
\text { regime }\end{array}$ \\
\hline Argentina & $1955-1958$ & 18 years & $\begin{array}{l}1958-1962 \\
1963-1966\end{array}$ & 40 years \\
& $1962-1963$ & & $1973-1976$ & \\
& $1966-1973$ & & $1983-2013$ & \\
& $1976-1983$ & & $1950-1973$ & 46 years \\
\hline Chile & $1973-1990$ & 17 years & $1958-2013$ & \\
\hline Colombia & $1953-1957$ & 4 years & $1950-1963$ & 54 years \\
\hline Ecuador & $1963-1965 ;$ & 9 years & $1965-1972$ & \\
& $1972-1979$ & & $1979-2013$ & \\
\hline
\end{tabular}

Source: Luis B Mejía, 2014

While these fluctuations in the political regime were a commonality in the four countries, the specific experiences were quite diverse. For example, the relative political stability of Chile and Colombia stands in sharp contrast with the constant turmoil endured by Argentina and Ecuador during the same period. This latter pair of countries has followed a path of institutional instability for much of the last six decades, with the constant alternation of authoritarian and democratic regimes being a feature of their political system for over half of the twentieth century. After the 1950s, the military seized the reins of government in Argentina on three occasions (1962, 1966, and 1977) while in Ecuador the military twice overthrew the civilian governments (1963 and 1972). Democratic elected governments were not only deposed by the militaries, with street protests and politicians also ousting Presidents in Ecuador and Argentina. For instance, Ecuador had eight Presidents between 1996 and 2005 while Argentina had three Presidents from 1999 to 2003. In the same way, during the $20^{\text {th }}$ century, the average life of Constitutions in Latin American countries was 28.7 years, with large variations among countries. Chile and Colombia had an average duration of their constitutions of more than 50 years, while Ecuador had a mean duration of its constitutions of 13 years (Nolte, 2011).

The institutional instability in Argentina and Ecuador was reflected in the trajectory of change of the planning body in these two countries. The Argentinean and Ecuadorian planning body have entirely changed their organizational 
structure six and four times respectively during the last sixty years. Both countries adopted and discharged agency arrangements that represent the whole array of structural outcomes in organizations, namely collegial body (commission, board or council), administrative unit within the internal organization of the Finance or Economy ministries, and ministry. This contrasts with the more gradual transformation trajectory of the planning organization of Chile and Colombia, both of which changed on two occasions.

Findings of this research reveal some consistent patterns of behavior: first, organizational change has occurred regardless of the existence of institutional instability at the country level; second, rather than emanating from outside, organizational change is often endogenous; and third, stronger legislative presidential and the existence of few veto point gives Presidents great prevalence in the creation and transformation of public agencies, including the Central Planning Agencies. Next section further elaborates on understanding the drivers of agency transformation for each of the cases studies by assessing whether empirical evidence was in place to validate the hypothesized causal mechanisms of organizational change presented in Chapter 3.

\subsection{Organizational change in a nutshell: timelines of transformations}

Figures 7 thru 10 summarize for each of the case studies the timeline of transformations followed by the planning agency. Situated above the timeline, the figure shows each successive transformation that the agency traversed. It includes, both major milestones of the agency's changes in its formal structure (creation of the agency; position within the hierarchy of the public sector; replacement of the agency by a "new" one; termination; merging with another agency, etc) as well as gradual transformations like the addition or elimination of certain functions and tasks. Right below the timeline, the figures highlight historical episodes of critical junctures, both from political and economic perspective. Finally in the bottom area of the figure, shaded in grey, the figure depicts the empirical evidence that supports that one or another part of the various causal mechanisms tested were indeed present, and the length of time that they were in place.

Figure 7 presents the timeline of transformations of the planning agency in Argentina. Changes in the formal structure of the planning agency primarily concentrated in the first 25 years since the agency's birth, which is also the period with the largest political instability, including two coups d'état. Throughout this period empirical accounts show the instrumental use of the agency by the executive, whether democratically elected or de facto, as the structuralinstrumental predicts. This was not the sole driver of change during this period. Evidence supports the influence of ECLA and other international advisors, in the 
structuring of the agency, in line with the environmental perspective. Scattered around, there are signals of the agency performing technical tasks that responded to changes in the economic model matching the task-specific approach, for example the regulatory and subsidy allocation tasks adopted by the agency since the early 2000s.

Ecuador's planning agency trajectory, as Argentina, was characterized by a large number of transformations of the agency's formal structure as well as fluctuations in the scope of functions assumed throughout history, all of this in a context of great political turmoil (Figure 8). In terms of the observable implications of the theories of organizational change in the case of Ecuador the strongest evidence observed supports the hypothesis of the environmental and cultural-institutional approaches. Ecuador had a strong outside influence from external actors in determining the agency's creation, initial structure, and staffing, influence that impressed a long-lasting seal on the organization that inertially continued in its same path until at least 1997 . However it is noteworthy that contrary to what the environmental approach proposes, Ecuador experienced numerous and strong critical junctures that did not insert the agency into a different trajectory as the theory suggests. As observed in the figure, the observable implications of the causal mechanisms suggested by the structural-instrumental and by the task specific approaches are hardly accounted for by the empirical data.

Unlike Argentina and Ecuador, the trajectory of change observed in the planning agency of Chile has been more stable (Figure 9). While the formal structure of the agency was only transformed in three occasions, the focus of the agency has radically shifted. This pattern of change coincides at certain points in history with various elements hypothesized by the causal mechanisms of organizational change. The birth of CORFO closely meets the structural-instrumental perspective. The historical accounts show the existence of interplay of political forces around the creation of CORFO between the legislative and the executive. After the agency's kicks off, historical accounts reflect a strong process of institutionalization in which the promotion of staff within the agency's hierarchy and the recruitment policies from among Universidad de Chile generated a feed-back effect as the cultural-institutional perspective suggests. Interesting in the case of Chile, is that forms of socialization are a common element both, under democratic and military regimes. Difference lies on the type of affiliation and ideas reproduced: Pinochet with the liberal ideas from University of Chicago and Universidad Católica on one side, and the democratic governments with ECLA and Universidad de Chile on the other side. In line with the task-specific perspective, another commonality in Chile's planning agency trajectory across periods of time is its adaption in its functions and tasks to respond to alternative models of development. The agency 
traversed from classical development planning functions in its earlier years, to deregulation, privatization and decentralization in the 1970s and 1980s, and finally toward social policy making since the late 1990s.

Of all case studies, the trajectory of change followed by the planning agency in Colombia is the most stable (Figure 10). While formal changes to the structure of the agency only occurred twice in almost sixty years, the narrative accounts show consistent evidence that gradual transformation was a constant characteristic throughout its trajectory, motivated by each incoming President assigning the agency with new tasks, internal units, responsibilities and their key development programs. The agency's creation and initial years of strengthening received the influence of external actors, such as ECLA and the World Bank, through technical assistance and conditionality loans like the environmental approach predicts. The World Bank, in particular saw the agency as its natural counterpart in loan negotiations. The initial technical expertise attained by the agency and reproduced among a close network of economists sharing the same ideas, created a generalizable trust in the agency by the executive, the legislative, think tanks, and other government agencies. There is concurring evidence from the environmental and task-specific perspectives that this in term, locked-in the organization into a task-specific trajectory, whereby the agency performed the varying set of tasks it was assigned, managing to stay at the center of decision-making until at least the early 2000s.

After having summarized the historical evidence from the four case studies in terms of the causal mechanisms and the observable implications of the external theories of organizational change presented in Chapter 3, this research finds that the structural-instrumental, cultural-institutional, environmental, and task-specific approaches indeed each contribute to explaining specific moments of change in the central planning offices. However, none of these theories in themselves are sufficient to account for the entire fifty years of organizational transformation. The following section addresses some of the shortfalls of each of the theories. 


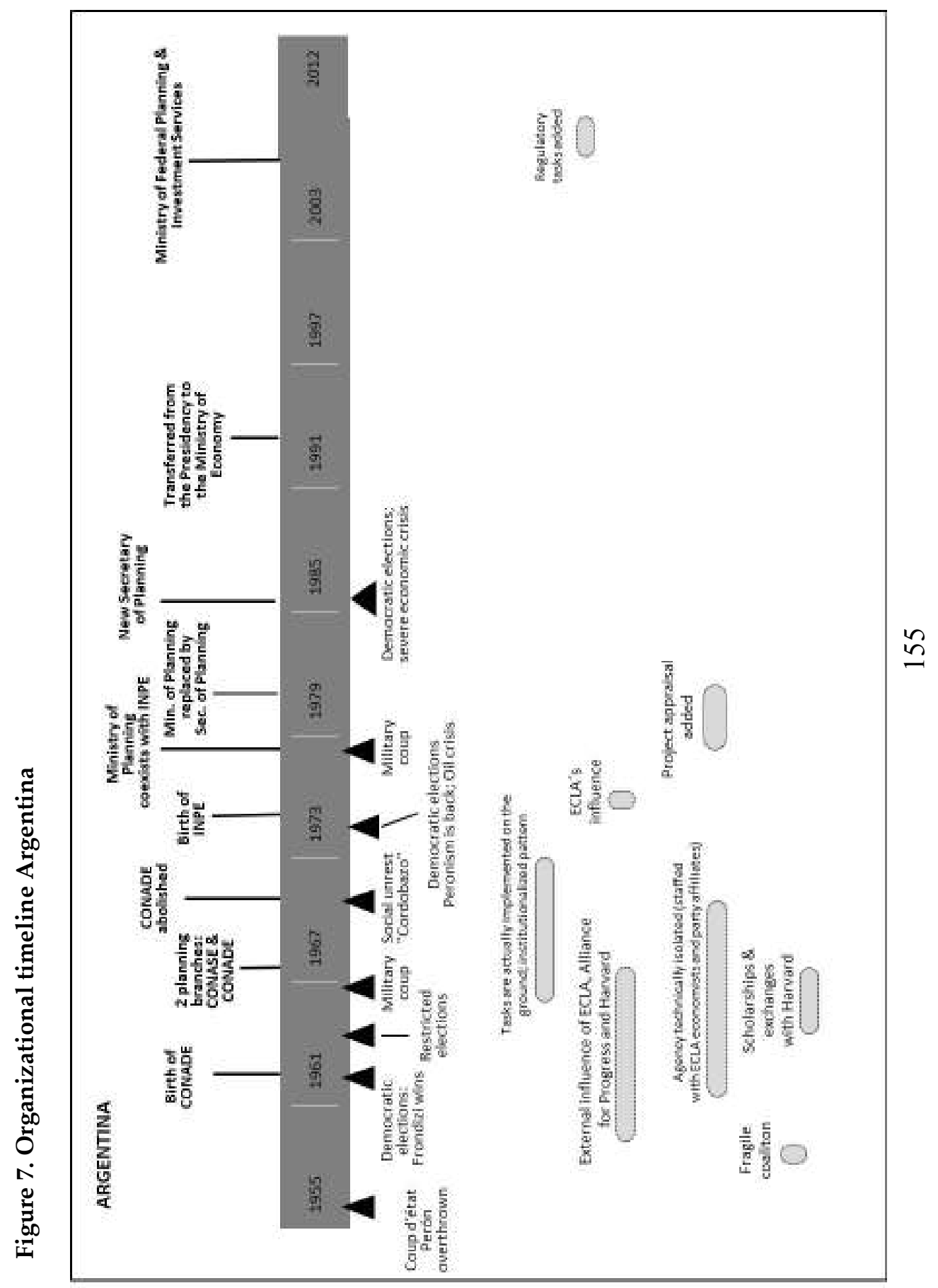




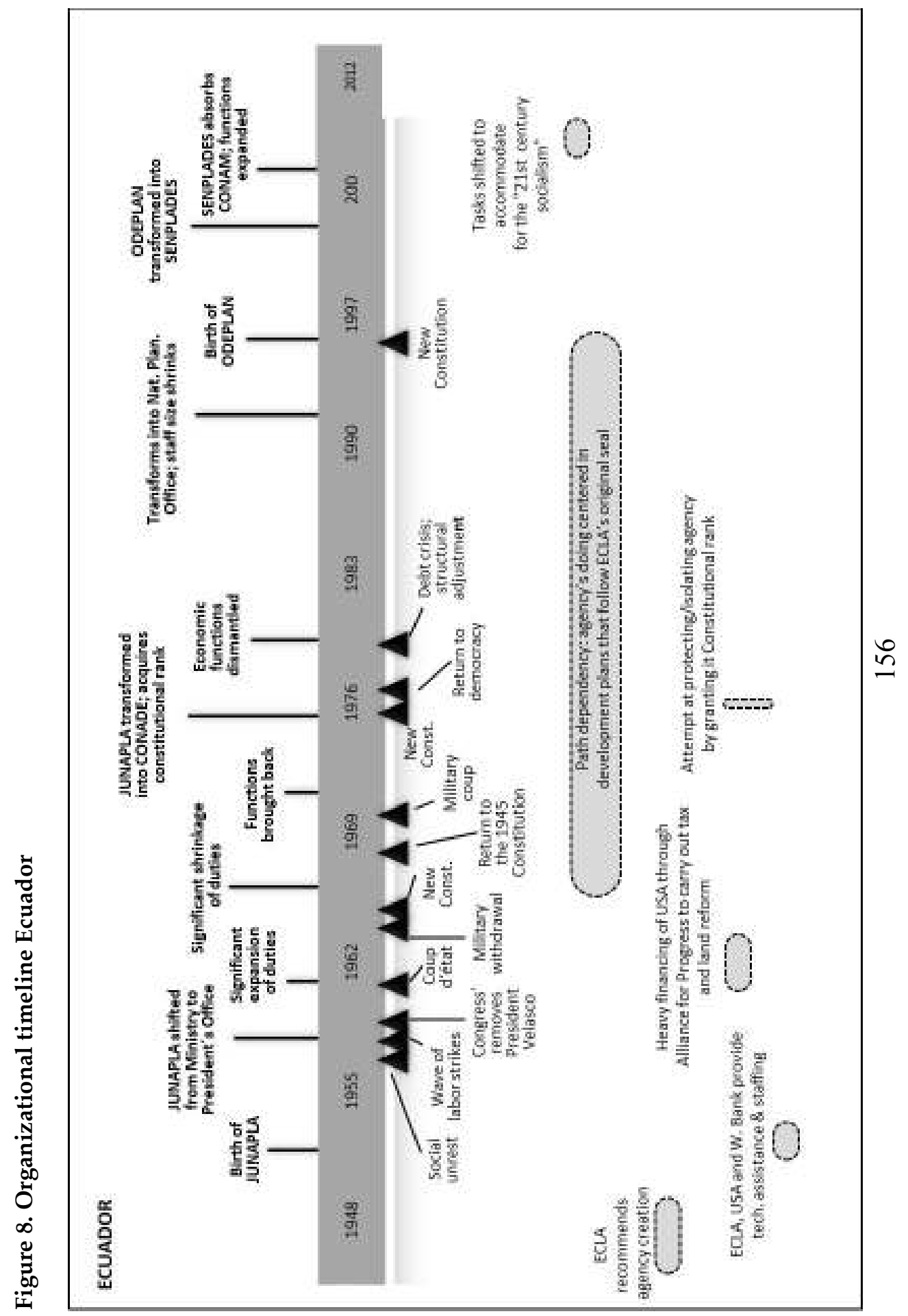




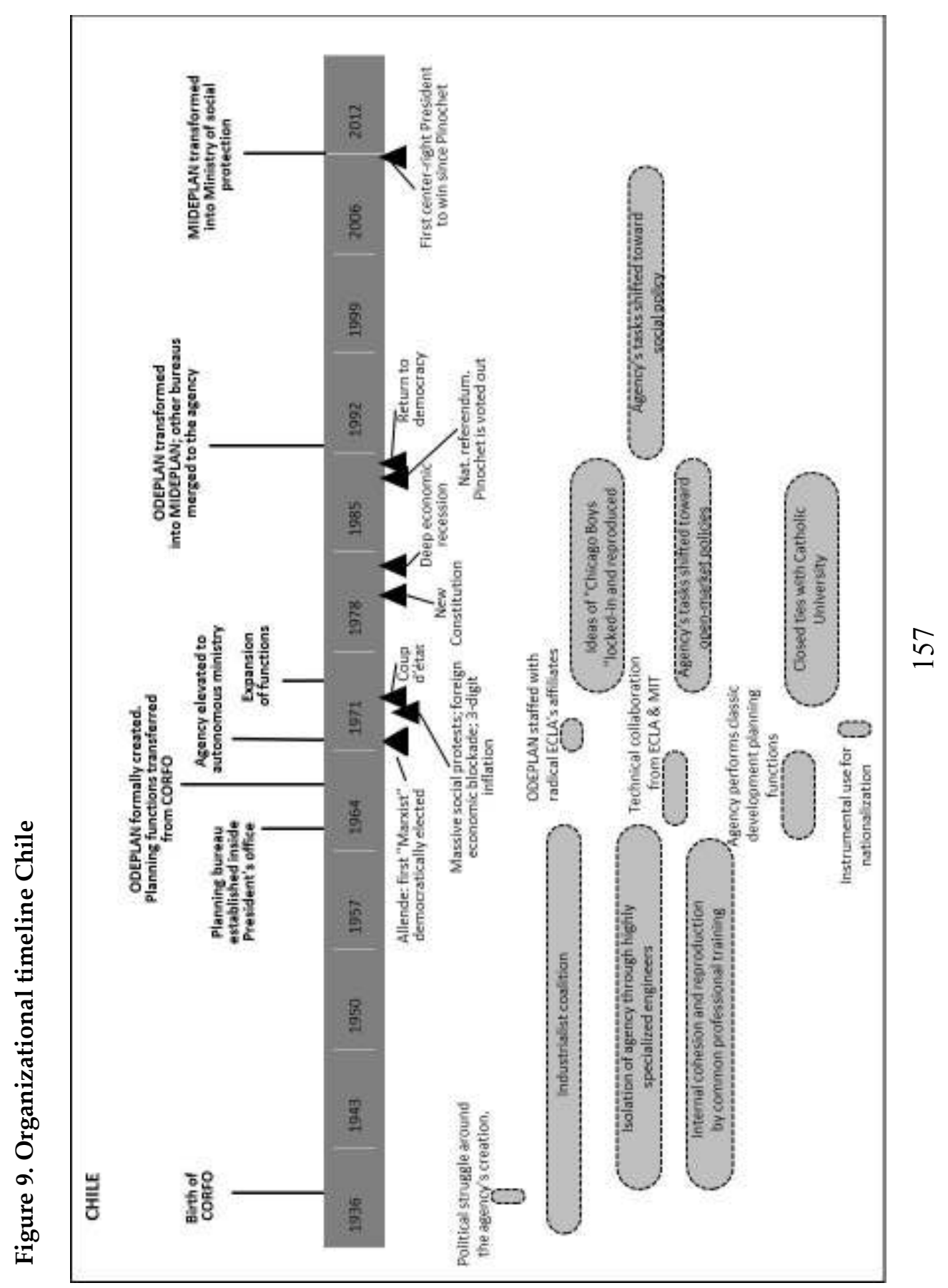




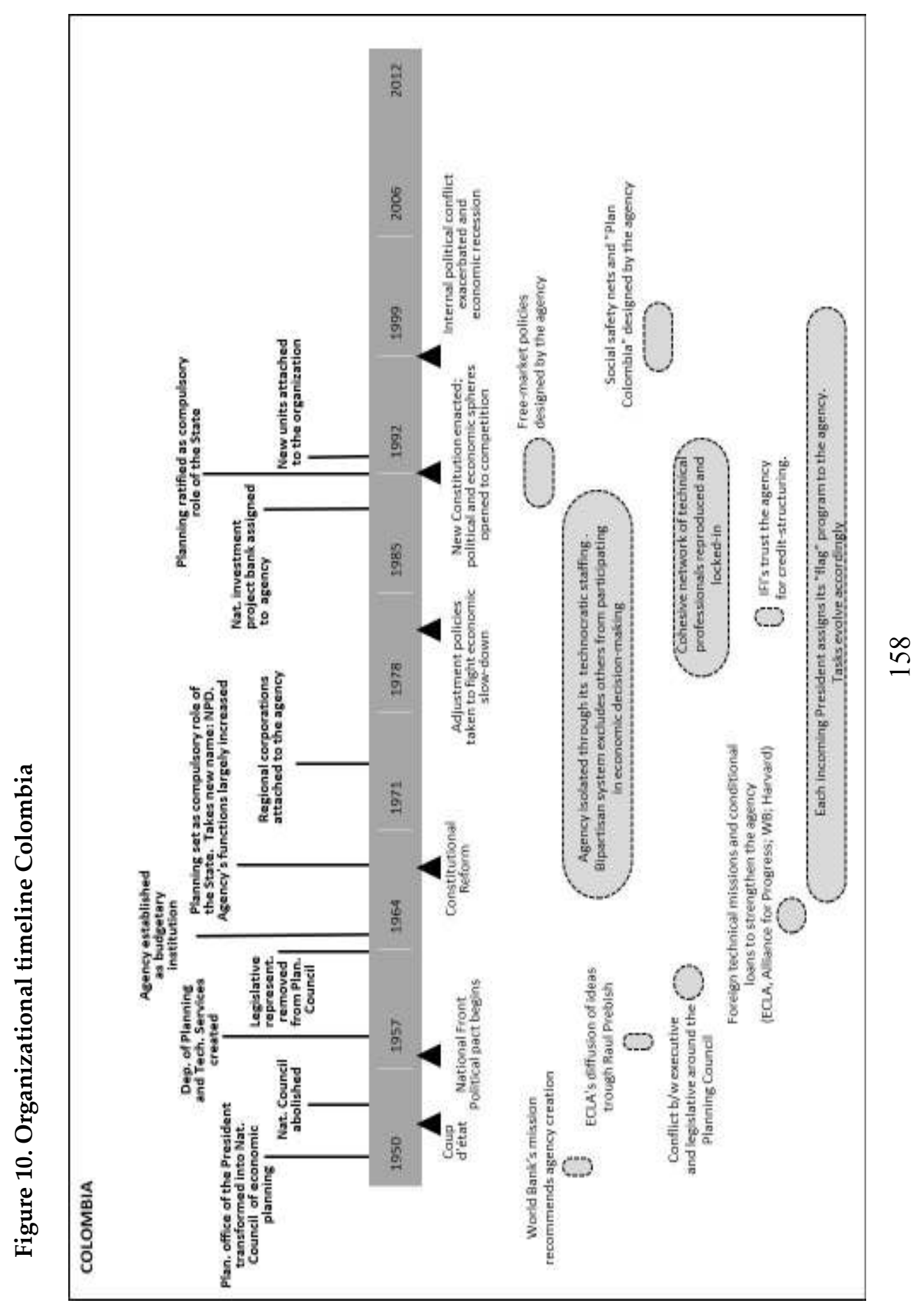




\subsection{The weight of the structural-instrumental perspective}

The empirical accounts gathered in this dissertation pose some challenges to validate the hypothesis of the structural-instrumental perspective for explaining organizational change. This approach suggests that agency transformation emerges out of political conflict and strategic bargaining among coalitions in the legislative. Here, the agency's adopted structure reflects the preferences of the enacting coalition, which also uses administrative procedures to predispose agencies towards policy choices preferred by legislators' favored constituents.

The first difficulty with the structural-instrumental approach is that the executive dominates the politics of agency design in Latin America. Therefore, administrative agencies cannot be seen as a mechanism used by Congress to ensure that the policy implementation reflects the preferences of legislators' enacting coalition. In fact, there is not an enacting coalition; in almost all cases, the creation of the planning organization occurred by executive decree. Even assuming that the creation of the planning organization rested on a particular balance of power, the historical transformation in the tasks performed by such organizations poses a doubt as to whether these agencies continued to benefit those who created them.

The second problem with the structural-instrumental perspective is that the agency's structural design in no way conditioned the particular role that the organization assumed throughout history. The historical narratives presented in this research show how ODEPLAN in Chile and the National Planning Department in Colombia, with the same basic design, performed functions that shifted from an inward development strategy to a free-market development model. On the other hand, despite the structural arrangement of the Argentinean and Ecuadorian planning organization having constantly changed from collegial bodies to the presidential office or ministry, the influence of the executive over such organization never changed. In other words, the Presidents in those countries had a great leverage over the planning agency, regardless of the organization's structural design.

The third drawback with the structural-instrumental approach is that neither the structural arrangement of the central planning agency nor administrative procedures have systematically been used to isolate the planning organization. As long as the President dominates the politics of agency scheme, the design of the planning organization has not been the product of inter-and intra-branch negotiations among political actors with individual interests shaped by their policy preferences. For example, Presidents have filled high-level planning agency posts with appointees whose preferences closely resemble those of the chief executive. In 
this sense, there is no necessity to calculate how to properly insulate the agency from the legislative. The same is true for administrative procedures, established by the legislative, in order to control the agency. In fact, the historical narratives presented show how the President has taken advantage of vague legislation in order to assign or change the tasks of the agency, regardless of whether the agency was structured as a collegial body, a presidential office or ministry.

Nonetheless, this does not mean that the President did not try, by means of creating bureaucratic capacity, to isolate the planning agency from politics. In the cases in which this isolation succeeded, it was thanks to the planning organization having created a publicly recognized capacity, expertise and monopoly on information. The planning bodies from Colombia, Chile, and Argentina during the 1960s are examples of this.

\subsection{The weight of the cultural-institutional perspective}

Findings in this research point that the planning agency in several of the countries studied experienced a path dependent trajectory at certain periods of time. Factors like the technical staffing of the agency's personnel, the quality and type of information that the agency treasured and the fact that in some countries, such as Ecuador, the planning agency was granted with Constitutional rank, were conditions that allowed contingent choices that set the agencies into a specific trajectory. However, from the stand point of the cultural-institutional theory of organizational change, periods of critical junctures are the source of institutional change, argument that is not systematically validated by the empirical data. All four countries underwent numerous critical junctures, but the cases offer counter evidence in which exogenous shocks did not prompt the organizational change of the planning bodies or when change occurred during periods of institutional stability. For example, the debt crises of 1982 hit Colombia as well the rest of Latin American countries. This crisis implied the abandonment of the importsubstitution industrialization as the country's economic model; however, the National Planning Department did not transform its functions radically at this time. Rather, throughout the 1980s and 1990s the agency gradually assumed functions related to the introduction of an outward economic development model. Contrary to Colombia, the planning agency in Chile underwent an important change as result of a critical juncture, particularly the coup d'état of 1973, when the agency drastically (in the course of a year) dropped all functions related with the state's intervention in the economy to assume neoliberal related functions. Nonetheless, with the return of democracy in 1990, ODEPLAN initiated a slow process of transformation that lasted twenty years. Finally, in Ecuador, when confronted with the same 1980s debt crisis, the planning agency did not suffer any 
change in its structural arrangement; rather, it simply moved into a long period of inertia.

\subsection{The weight of the environmental perspective}

The role played by international organizations in the creation and consolidation of the planning agencies is undeniable. Empirical evidence shows how ECLA and the Alliance for Progress influenced the specific organizational structures and the agency's functions throughout the 1960s. Characters like Celso Furtado, from ECLA, Richard Mallon from Harvard University, and Albert Waterston from the World Bank carried out technical assistance missions in the countries studied, disseminating the ideas of the organisms that they represented. However it is hard to argue that the historical moments of transformation or elimination of the central planning bodies were systematically influenced or directed by International Financial Institutions and powerful states.

Governments in the four countries studied, formally agreed to the contents of the Alliance for Progress, including the creation of central planning agencies and formulation of development plans. In practice however, the development plans rarely reached the implementation phase. Rather, as the case studies have shown, the development plans were useful in meeting the formal conditions required for obtaining financial aid yet they were seldom used in preparing or guiding economic policy. The alternation of political regimes, which showed opposed ideologies, orientations and development strategies, hindered the continuity of the development plans. In fact, as Table 14 summarizes, the average President length in office between 1961 and 1970 (period of duration of the Alliance for Progress) was 2.5 years in Argentina, 1.8 years in Ecuador, 4.5 years in Chile and 4 years in Colombia. During the same period, with the exception of Chile, each of these countries prepared two national development plans on average.

During this same period, ECLA reached its intellectual zenith in the region thanks to achieving consensus on development strategy. The historical narratives showed that many economists trained at ECLA occupied positions in the ministries of economy and planning, particularly in Chile and Argentina. However, this intellectual success did not translate into political influence. While plans were being formally approved and planning offices established, the politicians often ignored the economic recommendations of ECLA. 
Table 14

National Development Plans during the Alliance for Progress

\begin{tabular}{|c|c|c|c|c|}
\hline Country & Year & President & $\begin{array}{c}\text { National Development } \\
\text { Plan }\end{array}$ & $\begin{array}{l}\text { Planning } \\
\text { body }\end{array}$ \\
\hline \multirow{4}{*}{ Argentina } & $1958-1962$ & $\begin{array}{l}\text { Arturo } \\
\text { Frondizi }\end{array}$ & Long term sectoral plans & \multirow{4}{*}{$\begin{array}{l}\text { National } \\
\text { Development } \\
\text { Council- } \\
\text { CONADE }\end{array}$} \\
\hline & $1962-1963$ & $\begin{array}{l}\text { Jose Maria } \\
\text { Guido }\end{array}$ & No development plan & \\
\hline & 1963-1966 & Arturo Illia & $\begin{array}{c}\text { National Development } \\
\text { Plan 1965-1969 } \\
\end{array}$ & \\
\hline & $1966-1970$ & $\begin{array}{l}\text { Juan Carlos } \\
\text { Onganía } \\
\text { (Argentinean } \\
\text { Revolution) }\end{array}$ & $\begin{array}{c}\text { General Development } \\
\text { and Security Plan 1968- } \\
1977\end{array}$ & \\
\hline \multirow{2}{*}{ Chile } & $1958-1964$ & $\begin{array}{c}\text { Jorge } \\
\text { Alessandri }\end{array}$ & No development plan & \multirow{2}{*}{ ODEPLAN } \\
\hline & 1964-1970 & $\begin{array}{c}\text { Eduardo Frei } \\
\text { Montalva }\end{array}$ & No development plan & \\
\hline \multirow{3}{*}{ Colombia } & $1958-1962$ & Alberto Lleras & $\begin{array}{l}\text { General Economic and } \\
\text { Social Development Plan }\end{array}$ & \multirow{3}{*}{$\begin{array}{c}\text { National } \\
\text { Planning } \\
\text { Department }\end{array}$} \\
\hline & $1962-1966$ & $\begin{array}{c}\text { Guillermo } \\
\text { Leon Valencia }\end{array}$ & No development plan & \\
\hline & $1966-1970$ & Carlos Lleras & $\begin{array}{c}\text { Plans and development } \\
\text { programs }\end{array}$ & \\
\hline \multirow{5}{*}{ Ecuador } & 1961-1962 & $\begin{array}{l}\text { C.J. Arosemena } \\
\text { Monroy }\end{array}$ & $\begin{array}{c}\text { The Immediate } \\
\text { Development Plan 1961- } \\
1962\end{array}$ & \multirow{5}{*}{$\begin{array}{c}\text { National } \\
\text { Board of } \\
\text { Economic } \\
\text { Planning and } \\
\text { Coordination }\end{array}$} \\
\hline & $1963-1966$ & Military Junta & $\begin{array}{l}\text { General Economic and } \\
\text { Social Development Plan } \\
\text { of Ecuador 1964-1973 }\end{array}$ & \\
\hline & 1966 & $\begin{array}{l}\text { Clemente } \\
\text { Yerovi }\end{array}$ & No development plan & \\
\hline & $1966-1968$ & $\begin{array}{c}\text { Otto } \\
\text { Arosemena }\end{array}$ & No development plan & \\
\hline & 1968-1972 & $\begin{array}{l}\text { José María } \\
\text { Velasco Ibarra }\end{array}$ & $\begin{array}{l}\text { The Ecuadorian } \\
\text { Development 1970-1973 }\end{array}$ & \\
\hline
\end{tabular}

Source: Luis B Mejía, 2014

In the same way, the environmental perspective falls short at explaining why the planning agencies were not dismantled during the period in which the international pressure was pushing for structural adjustment programs and economic liberalization. While the external actor influence helps explaining the diffusion of ideas in the 1980s, related to state modernization, privatization, and shrinkage of the state it does not clarify why the planning agencies did not 
disappear, despite being the natural candidates to vanish when confronted with pro-market public sector reforms.

\subsection{The weight of the task-specific perspective}

The task-specific perspective emphasizes the technical environments of an organization, which might constrain and enable what an agency and its members are doing, and over time, changes in the technical environment might reflect subsequent transformations of the agency's functions. In this context, the taskspecific perspective could help explain the changes observed in the tasks of the central planning agencies as a response to the shift from the economic development model based on import substitution industrialization to the economic development strategy that relied on the principles of market forces and state retrenchment. This is the case in Chile, which implemented a rapid and extensive privatization, deregulation and reduction of trade barriers, when influenced by the Chicago Boys liberal school in the early-1970s, which translated into a change of scope of the planning agency. Later on, by the 2000s, when the prevailing economic model was calling for a comeback of the state's role to target poverty and income inequality, the agency in Chile responded by shifting its functions towards social policies targeted at minorities and vulnerable groups. In Colombia, despite being more paced, the functions of the planning agency responded to changes in the technical environment. Nonetheless, this explanation of agency change is less apparent for Argentina and Ecuador. For instance, during the military dictatorship in Argentina during the 1970s, the military government kept INPE with the same functions as during Peron's government, despite that the Ministry of Economy publicly declaring the need to move towards a pro-market model.

\subsection{Conclusion}

The process of explaining the drivers of institutional change of the planning agencies in Argentina, Ecuador, Chile and Colombia is very complex, multifactored and extremely context specific. However it is fairly reasonable to generalize that the alternative accounts in explaining the central planning organizational transformations were necessary but not sufficient to account for the entire fifty years of organizational transformation. There are pieces of evidence in each of the countries in support of one or another theory operating in a given historical moment; however none of the explanations are empirically validated to have occurred in a systematic manner. Among the various theories tested, the most salient one, without being sufficient to explain the outcome is: in Argentina the structural-instrumental emphasizing the rational political use of the agency; in Ecuador, the cultural perspective as path dependency conditioned the agency's trajectory; in Chile empirical evidence is stronger for the structural-instrumental and cultural institutional perspectives as there was political bargaining around the 
agency in its early years, and strong mechanisms of socialization and reproduction throughout the agency's life; and in Colombia there is concurrent evidence of both the environmental and the task-specific approach as the agency with its know-how did gradually adapt functionally to subsequent changes in the country's economic model.

Contrary to the scattered pieces of evidence in support of the above-mentioned theories, the empirical accounts find that the President's action (or inaction) has been systematically the major source of the organizational inertia or change in the four countries. Next Chapter explores in detail, the conditions that allow Presidents to be the main driver of organizational change. 


\section{Chapter 10: Explaining endogenous change}

As presented in Chapter 3, Mahoney and Thelen (2010) highlight the idea that the basic properties of institutions provide some dynamic elements that permit change. These scholars call specific attention to forms of change that are linked to two variables: veto possibilities and compliance.

The first variable (veto possibilities) is understood as the role of individual or collective actors whose agreement is necessary to change the status quo (Tsebelis, 2002). Tsebelis (2002) focuses on the effective number of institutional veto points, in the sense that it is more difficult to change policy the more veto points in a system, because the probability of a player exercising its veto option increases with numbers. Whether veto players or veto points, "veto possibilities are high where there exist actors who have access to institutional or extra-institutional means of blocking change" (Mahoney and Thelen, 2010, p.19). However, actors with strong veto possibilities vis-à-vis a given institution might not benefit from this strength vis-à-vis another institution.

The second variable (compliance) refers to the need to enforce the institution. Following Mahoney and Thelen (2010), the urgency to put institutions into effect not only emerge from the politically contested nature of institutional rules, but also from a degree of openness in the interpretation and implementation of these rules. "Even when institutions are formally codified, their guiding expectations often remain ambiguous and always are subject to interpretation, debate, and contestation" (Mahoney and Thelen, 2010, p. 11).

This Chapter explains, in the context of Latin America, why administrative reformminded Presidents do not have to navigate through a large number of veto points. Here, the President's formal power to introduce legislation on a broad range of policy areas, including administrative reorganizations, and to induce congressional action, is discussed. The second part of the Chapter documents how central planning agencies were enacted following vague statutes that left many details unspecified, opening the door to high levels of discretion and interpretation in formulating development policies. Finally the Chapter concludes by illustrating how the weak veto possibilities faced by those attempting to change the agency, combined with high levels of interpretation and low enforcement of the agency's mandates, has permitted a conversion mode of gradual and transformative organizational change, within which the President is singled out as the main driver of change. 


\subsection{Veto faculties and decree powers in Latin America}

According to Tsebelis (2002), one institutional feature of Latin American constitutions has remained unchanged since their establishment two hundred years ago: the President's formal power to introduce legislation on a broad range of policy areas and compel congressional action. These constitutional powers of the President allow him to initiate major policy change, or to prevent it from happening (Rius and van de Walle, 2003).

The President's faculties that have been most frequently stressed are his veto authority and decree power. Veto power refers to the situation in which no bill can become law without meeting the President's approval (Mainwaring and Shugart, 1997). After legislation is passed by the legislative and signed into law by the executive, the President implements the law via regulatory decrees, whereby detailed rules are attached to the more general provisions of the legislation (Sondrol, 2005). On the other hand, decree power means that the Presidents are allowed to legislate, without Congress, by means of a different kind of executive mandates such as decree-laws, regulatory directives, executive orders and instructions (Tsebelis and Aleman, 2005).

According to Mainwaring and Shugart (1997), veto power is essentially reactive because it allows the President to defend himself from the attempts of the legislative to alter the state of affairs through passing a new legislation. By contrast, decree power is proactive, given that it enables the President to initiate legislation submitted to Congress, in this way establishing a new status quo (Bonvecchi and Scartascini, 2011).

In addition to veto and decree powers, the President has the authority to set the policy agenda through mechanisms such as prioritizing bills, enacting urgency decrees and calling plebiscite or referendum in almost all countries of the region. Finally, Latin American Presidents also have the right to initiate legislation on a broad range of policy areas, including the budget and the reorganization of the public administration.

The power to maintain or reorganize the administrative apparatus enables Latin American Presidents not only to centralize control of decision making in the Presidency, but also to pursue public policy without Congress. According to Mainwaring (1990, p. 169), "when Presidents are incapable of pushing critical legislation through Congress, they often create new state agencies as a means of enhancing their power and accomplishing their agendas". A reformist agenda may move faster and further if Presidents find themselves in an office with significant constitutional legislative prerogatives (decree power, veto power, exclusive right of 
legislative introduction). A few examples from the case studies are illustrative: Decrees-Law 17614 of 1966 and 21630 of 1977 issued by Argentinean de facto Presidents Juan Carlos Onganía and Rafael Videla to rationalize the Public Administration; Decrees 2192/3/4 of 1986 pushed forward by President Raul Alfonsín to conduct state reform; power granted to President Carlos Menem to carry out the administrative reforms, which resulted in the downsizing of the Argentinean public sector (Law of the State Reform 23.696) was delegated by Congress to the President under the figure of economic emergency. In Colombia, Congress also delegated to Presidents Guillermo Leon Valencia, Carlos Lleras, and Misael Pastrana the authorization to restructure public administration in 1963 (Law 21), 1967 (Law 65), and 1973 (Law 2) respectively. Later on, in 1998, Congress granted the Colombian President permanent authorization to restructure and downsize public sector by means of issuing presidential decrees (Law 489 of 1998 and Law 790 of 2002). In Chile, the military Junta created CONARA, decree law 2093, as an organism in charge of advising the President on issues related to administrative reform. Finally, in Ecuador, President Sixto Durán Ballen issued executive Decree 1623 of 1994, setting out the general regulations for the State Modernization.

The tendency to pursue administrative reforms in Latin America through the executive rather than through Congress is present in the context of the planning agencies. Table 15 shows the rule of law that enacted the planning body in sixteen Latin American countries, including the four case studies, during the late-1950s and early-1960s. Twelve out of sixteen countries (Argentina, Bolivia, Brazil, Ecuador, Guatemala, Nicaragua, Panama, Paraguay, Peru, Uruguay and Venezuela) created their central planning organization through a rule of law issued by the head of state (Decree, Decree Law, Presidential Agreement, etc.). The remaining four countries (Chile, Colombia, Costa Rica and Dominican Republic) enacted their planning body through Congress-approved Law. However, in these four cases it was the President (executive) who initiated the legislation, submitting the draft bill to Congress.

The authority of Latin American Presidents to create, transform and terminate administrative agencies has not significantly changed since the onset of the planning offices. Table 16 shows the rule of law of the latest administrative reorganization of the planning body in fifteen Latin American countries. Here, nine countries (Argentina, Brazil, Colombia, Ecuador, Guatemala, Nicaragua, Paraguay, Uruguay and Venezuela) transformed their planning agency through a rule of law issued by the President (Decree, Decree Law, Presidential Agreement, Provisional Measure, etc.), while the remaining six countries (Bolivia, Chile, Costa Rica, Dominican Republic, Panama and Peru) changed their planning body trough 
Law. Once again, in these latter countries, it was the President who initiated the legislation, submitting the respective bill to Congress.

Table 15

Legal instrument underpinning the creation of the planning office

\begin{tabular}{|c|c|c|c|}
\hline Country & Planning body & Rule of law & Year \\
\hline Argentina & $\begin{array}{l}\text { Consejo Nacional de Desarrollo de la } \\
\text { Nación (CONADE) }\end{array}$ & Decree 7.290 & 1961 \\
\hline Bolivia & Junta Nacional de Planeamiento & $\begin{array}{l}\text { Supreme Decree } \mathrm{N}^{\circ} \\
5600\end{array}$ & 1960 \\
\hline Brazil & Ministério de Planejamento & Delegated law No. 1 & 1962 \\
\hline Chile & Oficina de Planificación (ODEPLAN) & Law $N^{\circ} 16.635$ & 1967 \\
\hline Colombia & $\begin{array}{l}\text { Departamento Administrativo de } \\
\text { Planeación y Servicios Técnicos }\end{array}$ & Law 19 & 1958 \\
\hline Costa Rica & $\begin{array}{l}\text { Oficina de Planificación de la } \\
\text { Presidencia de la República }\end{array}$ & Law № 3087 & 1963 \\
\hline $\begin{array}{l}\text { Dominican } \\
\text { Republic }\end{array}$ & $\begin{array}{l}\text { Junta Nacional de Planificación y } \\
\text { Coordinación }\end{array}$ & Law 5788 & 1962 \\
\hline Ecuador & $\begin{array}{l}\text { Junta Nacional de Planificación y } \\
\text { Coordinación Económica (Junapla) }\end{array}$ & $\begin{array}{ll}\text { Emergency } & \text { Decree } \\
\text { Law } N^{\circ} 19 & \\
\end{array}$ & 1954 \\
\hline Guatemala & $\begin{array}{l}\text { Consejo Nacional de Planificación } \\
\text { Económica }\end{array}$ & Decree Law 114 & 1954 \\
\hline Mexico & $\begin{array}{l}\text { Comisión Intersectorial para la } \\
\text { Formulación de Planes de Desarrollo }\end{array}$ & $\begin{array}{l}\text { Presidential } \\
\text { Agreement }\end{array}$ & 1962 \\
\hline Nicaragua & Oficina de Planificación Económica & Decree 52 & 1962 \\
\hline Panama & $\begin{array}{l}\text { Dirección General de Planificación y } \\
\text { Administración }\end{array}$ & Decree Law 11 & 1961 \\
\hline Paraguay & $\begin{array}{l}\text { Secretaria Técnica de Planificación del } \\
\text { Desarrollo Económico y Social }\end{array}$ & Decree - Law № 312 & 1962 \\
\hline Peru & Instituto Nacional de Planificación & $\begin{array}{lll}\begin{array}{l}\text { Decree } \\
14220\end{array} & \text { Law } & N^{\circ} \\
\end{array}$ & 1962 \\
\hline Uruguay & $\begin{array}{l}\text { Comisión de Inversiones y Desarrollo } \\
\text { Económico (CIDE) }\end{array}$ & Executive power & 1960 \\
\hline Venezuela & $\begin{array}{l}\text { Oficina Central de Coordinación y } \\
\text { Planificación de la Presidencia de la } \\
\text { República }\end{array}$ & Decree $\mathbf{N}^{\circ} 287$ & 1958 \\
\hline
\end{tabular}

Source: Luis B Mejía, 2014 
Table 16

Legal instruments used to transform the planning offices

\begin{tabular}{|c|c|c|c|}
\hline Country & Planning body & Rule of law & Year \\
\hline Argentina & $\begin{array}{l}\text { Ministerio de Planificación } \\
\text { Federal, Inversión Pública y } \\
\text { Servicios }\end{array}$ & Decree 27 & 2003 \\
\hline Bolivia & $\begin{array}{l}\text { Ministerio de Planificación del } \\
\text { Desarrollo }\end{array}$ & $\begin{array}{l}\text { Law on Organization of the } \\
\text { Executive Branch № } 3351\end{array}$ & 2006 \\
\hline Brazil & $\begin{array}{l}\text { Ministerio do planejamento, } \\
\text { orcamento e gestao }\end{array}$ & $\begin{array}{l}\text { Executive } \quad \text { Provisional } \\
\text { Measure No. 1911-8 }\end{array}$ & 1999 \\
\hline Chile & $\begin{array}{l}\text { Ministerio de planificacion } \\
\text { nacional (MIDEPLAN) }\end{array}$ & Law $\mathrm{N}^{\circ} 18.899$ & 1990 \\
\hline Colombia & $\begin{array}{l}\text { Departamento Nacional de } \\
\text { Planeación }\end{array}$ & Decree 1832 & 2012 \\
\hline Costa Rica & $\begin{array}{l}\text { Ministerio de Planificación } \\
\text { nacional y política económica } \\
\text { (MIDEPLAN) }\end{array}$ & Law No. 5525 & 1973 \\
\hline $\begin{array}{l}\text { Dominican } \\
\text { Republic }\end{array}$ & 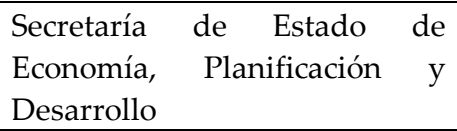 & Law No. 496 & 2006 \\
\hline Ecuador & $\begin{array}{lcc}\begin{array}{l}\text { Secretaria } \\
\text { planificación y desarrollo }\end{array} & \text { nacional } \\
\end{array}$ & Executive Decree No. 1372 & 2004 \\
\hline Guatemala & $\begin{array}{lcc}\text { Secretaria de } & \text { Planificación } & \text { y } \\
\text { Programación } & \text { de } & \text { la } \\
\text { Presidencia (SEGEPLAN) } & \end{array}$ & $\begin{array}{l}\text { Governmental agreement } \\
224\end{array}$ & 2003 \\
\hline Nicaragua & $\begin{array}{lrr}\text { Consejo } \quad \text { Nacional } & \text { de } \\
\text { Planificación } \quad \text { Económica } & y \\
\text { Social (CONPES) } & \\
\end{array}$ & Executive Decree 113 & 2007 \\
\hline Panama & $\begin{array}{l}\text { Ministerio de Planificación y } \\
\text { Política Económica }\end{array}$ & Law 97 & 1998 \\
\hline Paraguay & $\begin{array}{l}\text { Secretaría } \\
\text { Técnica de } \\
\text { Planificación del Desarrollo } \\
\text { Económico y Social de la } \\
\text { Presidencia de la República }\end{array}$ & Decree $\mathrm{N}^{\circ} 4.070$ & 2004 \\
\hline Peru & $\begin{array}{l}\text { Centro Nacional de } \\
\text { Planeamiento } \\
\text { (CEPLAN) }\end{array}$ & Law 28522 & 2009 \\
\hline Uruguay & $\begin{array}{l}\text { Oficina de Planeamiento y } \\
\text { Presupuesto }\end{array}$ & Decree 91 & 1997 \\
\hline Venezuela & $\begin{array}{l}\text { Ministerio de Planificación y } \\
\text { Finanzas }\end{array}$ & Presidential Decree $N^{\circ} 7.187$ & 2010 \\
\hline
\end{tabular}

Source: Luis B Mejía, 2014

Additional data collected for the four case studies is presented in Table 17 showing that Presidents in these countries extensively used their decree power to 
restructure the planning agencies: in Argentina, Presidents restructured the planning body eight times (three by presidential decree and five by law); in Chile, Presidents did so five times (two times by presidential decree and three by Law); in Colombia, this frequency was up to 15 times (13 by decree and two by Law); and in Ecuador, Presidents changed the planning body six times, all by presidential decree. These modifications prompted by the Presidents gradually reshaped the planning agencies by altering its organizational structure, adding and/or withdrawing functions and relocating the position and hierarchy of the agency visa-vis other public agencies.

Table 17

Amendments to the planning agencies made by presidential mandate

\begin{tabular}{|c|c|c|c|c|}
\hline & Argentina & Chile & Colombia & Ecuador \\
\hline $\begin{array}{l}1950- \\
1960\end{array}$ & & & $\begin{array}{l}\text { Law } 19 \text { of } 1958 \\
\text { Decree } 0239 \text { of } \\
1959\end{array}$ & $\begin{array}{l}\text { Emergency } \\
\text { Decree Law } 19 \\
\text { of } 1954\end{array}$ \\
\hline $\begin{array}{l}1960- \\
1970\end{array}$ & $\begin{array}{l}\text { Decree } 7.290 \text { of } \\
1961 \\
\text { Law } 16.964 \text { of } \\
1966\end{array}$ & $\begin{array}{l}\text { Law } N^{\circ} 16.635 \text { of } \\
1967\end{array}$ & $\begin{array}{l}\text { Decree- law } \\
3242 \text { of } 1963 \\
\text { Decree } 2996 \text { of } \\
1968\end{array}$ & \\
\hline $\begin{array}{l}1970- \\
1980\end{array}$ & $\begin{array}{l}\text { Decree } 1.057 \text { of } \\
1973 \\
\text { Law } 21.431 \text { of } \\
1977 \\
\text { Law } 21.909 \text { of } \\
1978\end{array}$ & $\begin{array}{l}\text { Decree } N^{\circ} 303 \text { of } \\
1971 \\
\text { Decree } 966 \text { of } \\
1975\end{array}$ & $\begin{array}{l}\text { Decree } 983 \text { of } \\
1972 \\
\text { Decree } 294 \text { of } \\
1973 \\
\text { Decree law } 627 \\
1974\end{array}$ & \\
\hline $\begin{array}{l}1980- \\
1990\end{array}$ & $\begin{array}{l}\text { Law of } \\
\text { Ministries of } \\
1983\end{array}$ & & $\begin{array}{l}\text { Law } 38 \text { of } 1989 \\
\text { Decree } 2410 \text { of } \\
1989\end{array}$ & \\
\hline $\begin{array}{l}1990- \\
2000\end{array}$ & & $\begin{array}{l}\text { Law } \mathrm{N}^{\circ} 18.989 \text { of } \\
1990\end{array}$ & $\begin{array}{l}\text { Decree } 2167 \text { of } \\
1992 \\
\text { Decree } 1363 \text { of } \\
\text { July } 2000\end{array}$ & $\begin{array}{l}\text { Executive } \\
\text { Decree } 120 \text { of } \\
1998\end{array}$ \\
\hline $\begin{array}{l}2000- \\
2010\end{array}$ & $\begin{array}{l}\text { Law of } \\
\text { Ministries } 26.338 \\
\text { of } 2003 \\
\text { Decree } N^{\circ} 1283 \\
\text { of May, } 2003\end{array}$ & & $\begin{array}{l}\text { Decree } 160 \text { of } \\
2002 \\
\text { Decree } 195 \text { of } \\
2004 \\
\text { Decree } 4355 \\
\text { of } 2005 \\
\text { Decree } 3517 \text { of } \\
2009\end{array}$ & $\begin{array}{l}\text { Executive } \\
\text { Decree } 1372 \text { of } \\
2004 \\
\text { Executive } \\
\text { Decree } 103 \text { of } \\
2007\end{array}$ \\
\hline
\end{tabular}

Source: Luis B Mejía, 2014 
Latin American Presidents have also been bestowed by constitution with the power to nominate, appoint and dismiss government officials, including the head of the planning organization. "In Latin America, it is common for each incoming President to change not only the people in charge of the ministries but also the overall structure of government by creating new ministries, eliminating others, changing their names, functions, and scope, and the like" (Scartascini, 2010, p. 38).

\subsection{The ambiguity in the interpretation and implementation of the central planning agencies in Latin America}

Chun and Rainey (2005, p. 3) define goal ambiguity as "the extent to which an organizational goal or set of goals allows leeway for interpretation". An organizational goal loses clear significance and becomes vague when it invites a number of different interpretations (DiMaggio, 1987; Feldman, 1989; Locke et al, 1989; Epstein and O'Halloran, 1999; Kelemen, 2000; Huber and Shipan, 2002).

By the mid-1960s, all Latin American countries had a permanent organization inside the machinery of the central government responsible for planning activities. Although central planning agencies structurally evolved in diverse ways in different countries, their goals and procedures nonetheless manifested prominent similarities. Planning bodies were in charge of (i) advising the executive in preparing National Development Plans based upon macro-economic analysis and econometric models; (ii) assisting the President on economic matters; (iii) coordinating development activities of line ministries and administrative agencies; and (iv) executing studies on the national economy. It was not unusual for mandates and functions to be broad. As functions for the four case studies have already been presented, a few specific examples from other countries (Uruguay and Paraguay) are depicted in Table 18 to further illustrate this statement.

Almost all these goals were unclear because people could have many possible ways of interpreting words such as economic strategy, national productivity, development plans and development policy, depending on their political and economic standpoint. Moreover, even if people should agree on the meaning of one goal, they could still disagree on the specific way of attaining it (Wilson, 1989). By the mid-1960s, Waterston (1966) observed that this situation contributed to the central planning agencies being called to do tasks that were unrelated to planning. "For example, the Venezuelan central planning agency initiated a program for establishing seven automotive assembly plants, and carried out the program over a two-year period before turning it over to a ministry" (Waterston, 1966, p. 421). 
Table 18

Central planning agency mandates (1960s)

\begin{tabular}{|c|c|c|c|}
\hline Country & Planning agency & Year & Mandates \\
\hline Uruguay & $\begin{array}{l}\text { Investment and } \\
\text { Economic } \\
\text { Development } \\
\text { Commission }\end{array}$ & 1960 & $\begin{array}{l}\text { Executive Power (National Council of } \\
\text { Government): } \\
\text { 1. Formulate economic } \\
\text { development plans } \\
\text { 2. Project and seek internal and } \\
\text { external funding } \\
\text { 3. Coordinate efforts aimed at } \\
\text { increasing national } \\
\text { productivity } \\
\text { 4. Advise the Executive on the } \\
\text { definition of economic } \\
\text { strategy } \\
\text { 5. Monitor the implementation } \\
\text { of the approved plans }\end{array}$ \\
\hline Paraguay & $\begin{array}{l}\text { Secretary of Planning, } \\
\text { Economic and Social } \\
\text { Development }\end{array}$ & 1962 & $\begin{array}{l}\text { Decree Law № } 312 \\
\text { 1. Analyze the economic } \\
\text { situation and its trends } \\
\text { 2. Make recommendations } \\
\text { about the general direction of } \\
\text { development policy } \\
\text { 3. } \text { Elaborate sectoral and } \\
\text { regional development goals } \\
\text { 4. Coordinate technical } \\
\text { assistance programs and } \\
\text { financial aid from } \\
\text { international and } \\
\text { governmental agencies } \\
\text { Advise the National } \\
\text { Economic Coordination } \\
\text { Council } \\
\text { 6. Valuate that development } \\
\text { plans and investments are } \\
\text { properly executed. } \\
\text { 7. Make periodic reports to the } \\
\text { Executive about the result of } \\
\text { the development plans } \\
\text { 8. Participate in the study of the } \\
\text { Nation's General Budget }\end{array}$ \\
\hline
\end{tabular}

Source: Luis B Mejía, 2014 
The leeway for interpretation of the central planning agency's organizational goals has not significantly changed since Waterston's research was published. One approach to assess the extent of ambiguity in the mission statements of the Latin American central planning agencies is the Gunning Fog index, an indicator for evaluating the degree of blurriness in a written passage. In this sense, the GFI predicts the extent to which a piece of writing can be easily understood by readers. Some previous research has used this index as an indicator of mission statement clarity. For example, Weiss and Piderit (1999) applied the GFI to the mission statements of 304 public schools in order to assess the impact of mission clarity on school performance. Later, in their effort to evaluate the extent of ambiguity in the goals of the American Federal Administrative agencies, Chun and Rainey (2005) utilized the GFI in combination with other three indicators: directive goal ambiguity, evaluative goal ambiguity and priority goal ambiguity. Specifically, through the GFI, Chun and Rainey measured the mission's comprehension ambiguity.

The GFI captures average sentence length and the frequency of use of multisyllabic words: 160 the higher the GFI, the harder the written passage is to comprehend. While near-universal understanding requires an index of less than 8 for texts in English, in Spanish it calls for an index no greater than 20. As illustrated in Graph 1 the GFI was applied to the current mission of ten Latin American planning organizations, including the four case studies, attaining an average score of 36.2. Scores obtained for the cases studies were 47.9 in Argentina, 25.2 in Ecuador, 37.4 in Chile and 52.4 in Colombia.

These rather high scores suggest that the mission statement of the planning agencies is complicated and hard to communicate, thus allowing for great possibility of interpretation in terms of what the agency is expected to do. For example, observe the low readability or lack of clarity in the mission statement of the Colombian planning agency:

160 The Gunning Fog Index was originally constructed by Robert Gunning in 1952. The algorithm starts by determining the average sentence length, before introducing a count of complex words and subsequently averaging the sentence length with the percentage of complex words by use of the following formula: $0.4\left[\left(\frac{\text { words }}{\text { Sentences }}\right)+100\left(\frac{\text { Complex words }}{\text { Words }}\right)\right]$ 
The National Planning Department in its advisor role to the National Government promotes a strategic vision for the country, leads and orients the formulation of the National Development Plan and the assignment and monitoring of the investment resources targeted to the medium and long term objectives; it orients, formulates, monitor and evaluates policies, plans, programs and projects for economic, social and environmental development of the country, by means of a coordinated inter-institutional work with national and territorial entities, and with responsibility towards the citizenry. ${ }^{161}$

\section{Graph 1}

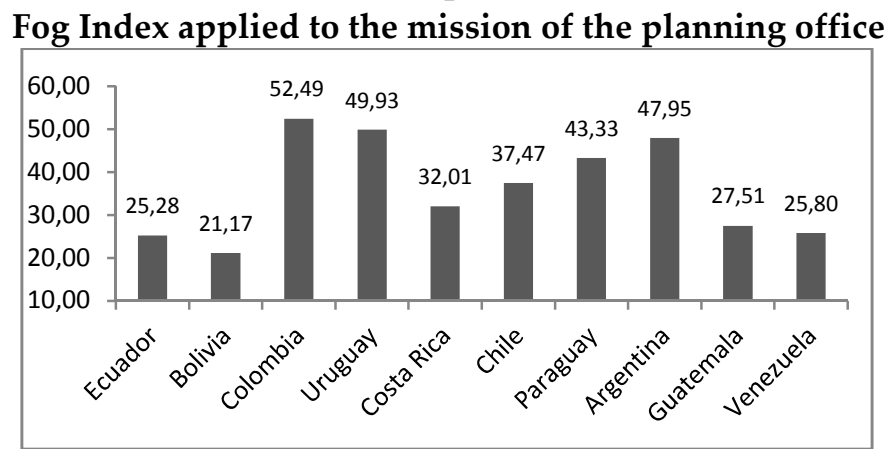

Source: Luis B Mejía, 2014

However, aware that the GFI is not free of subjectivity and that Chun and Rainey (2013) stated that the GFI of an agency's mission statement did not have any statistically expected effect on various empirical studies, this research complements the GFI with the work inspired by Huber and Shipan (2002) on Deliberate Discretion. The authors explore how elected officials use statutes to establish policy details in an effort to achieve desired outcomes. In this context, the scholars pay attention to two different strategies: one is to write long statutes with extremely detailed language in an effort to micromanage the policy making process; while the other is to write vague statutes that leave many details

161 Original statement of mission in Spanish: "Como organismo técnico asesor del Gobierno Nacional, el Departamento Nacional de Planeación impulsa una visión estratégica de país, lidera y orienta la formulación del Plan Nacional de Desarrollo y la programación y seguimiento de los recursos de inversión dirigidos al logro de los objetivos de mediano y largo plazo, orienta, formula, monitorea, evalúa y hace seguimiento a las políticas, planes, programas y proyectos para el desarrollo económico, social y ambiental del país, a través de un trabajo interinstitucional coordinado con las entidades del orden nacional y territorial, con sentido de responsabilidad frente a la ciudadanía." 
unspecified, thereby delegating policy making authority to bureaucrats (Huber and Shipan, 2002).

Based on Huber and Shipan, this research quantifies the lack of precision in the planning agencies' current functions as the percentage of functions that fall under a general policy language, as opposed to specific policy language. Specific tasks are understood here as those that entail the agency doing something concrete and measurable, such as formulating the national development plan, preparing the annual investment budget and establishing the evaluation criteria for the national development plan, while general policy language entails broad functions such as coordinating decentralization policies, advising the President on economic matters, conducting sectoral and macroeconomic studies, participating in the definition of economic policy, etc. Table 19 provides examples of general and specific policy language for some of the functions of the planning agencies of the four case studies.

Table 20 codes the above mentioned percentage for the planning functions of eleven planning agencies of Latin America. With the exception of Guatemala, which presents a $38 \%$ of general policy language, more than $50 \%$ of the functions of the central planning agencies consistently fall under a general policy language across all other countries analyzed, the upper case being Peru, with $78 \%$. The percentage of general-policy functions in the four case studies is: Argentina 54\%, Ecuador $60 \%$, Chile $70 \%$ and Colombia $55 \%$.

In summary the previous data call attention to the fact that both mandates and functions of the central planning offices, including those in Argentina, Ecuador, Chile and Colombia, are written under a broad policy language leaving many details unspecified, placing few constrains to implementation and allowing room for interpretation or the emergence of gaps between the purposes for which the planning agencies are designed and their actual on-the-ground implementation. 
Table 19

Examples of General and Specific Policy language

\begin{tabular}{|c|c|c|c|}
\hline Country & Decree/Law & $\begin{array}{l}\text { Example of General Policy } \\
\text { Language }\end{array}$ & $\begin{array}{c}\text { Example of Specific Policy } \\
\text { Language }\end{array}$ \\
\hline Argentina & Decree 27/ 03 & $\begin{array}{c}\text { Understand the } \\
\text { establishment of goals and } \\
\text { policies in its own } \\
\text { competence areas. }{ }^{162}\end{array}$ & $\begin{array}{c}\text { Intervene on the definition of } \\
\text { the structure of import } \\
\text { taxes }^{163} \text {. }\end{array}$ \\
\hline Ecuador & $\begin{array}{c}\text { Executive } \\
\text { Decree 1372/ } \\
04\end{array}$ & $\begin{array}{l}\text { Process, harmonize and } \\
\text { conciliate the set of public } \\
\text { policies and integrate them } \\
\text { to the Development } \text { Plan }^{164} \text {. }\end{array}$ & $\begin{array}{l}\text { Propose alternatives and } \\
\text { necessary resources for the } \\
\text { financing of national and } \\
\text { sub-national development } \\
\text { plans } \text { s }^{165} \text {. }\end{array}$ \\
\hline Chile & Law 18.899/ 90 & $\begin{array}{l}\text { Propitiate research on } \\
\text { planning and evaluation } \\
\text { techniques } \\
\text { t66. }\end{array}$ & $\begin{array}{l}\text { Set the social and economic } \\
\text { valuation criteria for } \\
\text { investment projects financed } \\
\text { directly or indirectly by the } \\
\text { state }\end{array}$ \\
\hline Colombia & $\begin{array}{l}\text { Decree 1832/ } \\
\qquad 12\end{array}$ & $\begin{array}{l}\text { Promote and coordinate } \\
\text { research and studies on } \\
\text { modernization and } \\
\text { technification of the macro- } \\
\text { structure of the State }{ }^{168} \text {. }\end{array}$ & $\begin{array}{l}\text { Approve the methodologies } \\
\text { for the identification, } \\
\text { formulation and evaluation } \\
\text { of projects financed with } \\
\text { public resources } \\
\text { 169. }\end{array}$ \\
\hline
\end{tabular}

Source: Luis B Mejía, 2014

${ }^{162}$ Original text in Spanish: "Entender en la determinación de los objetivos y políticas del área de su competencia".

${ }^{163}$ Original text in Spanish: "Intervenir en la elaboración de las estructuras arancelarias".

164 Original text in Spanish: "Procesar, armonizar y conciliar el conjunto de políticas públicas e integrarlas en el Plan de Desarrollo".

165 Original text in Spanish: "Proponer las modalidades y recursos necesarios para el financiamiento de los planes nacionales, regionales y provinciales de desarrollo".

166 Original text in Spanish: "Propiciar investigaciones sobre técnicas de planificación y de evaluación en las materias asignadas al Ministerio"

167 Original text in Spanish: Establecer los criterios de evaluación económica y social para los proyectos de inversión financiados directa o indirectamente por el Estado".

168 Original Text in Spanish: "Promover, elaborar y coordinar estudios e investigaciones atinentes a la modernización y tecnificación de la macroestructura del Estado".

169 Original text in Spanish: "Aprobar las metodologías para la identificación, formulación y evaluación de los proyectos financiados con recursos nacionales". 
Table 20

Percentage of functions that fall under general or specific policy language

\begin{tabular}{|c|c|c|c|c|c|}
\hline & \multicolumn{2}{|c|}{ General Policy Language } & \multicolumn{2}{|c|}{ Specific Policy Language } & \multirow{2}{*}{$\begin{array}{c}\text { TOTAL } \\
\text { FUNCTIONS }\end{array}$} \\
\hline & No. & Percentage & No. & Percentage & \\
\hline Argentina & 29 & $54 \%$ & 25 & $46 \%$ & 54 \\
\hline Bolivia & 9 & $64 \%$ & 5 & $36 \%$ & 14 \\
\hline Brasil & 8 & $73 \%$ & 3 & $27 \%$ & 11 \\
\hline Colombia & 18 & $55 \%$ & 15 & $45 \%$ & 33 \\
\hline Costa Rica & 2 & $50 \%$ & 2 & $50 \%$ & 4 \\
\hline Ecuador & 12 & $60 \%$ & 8 & $40 \%$ & 20 \\
\hline Chile & 7 & $70 \%$ & 3 & $30 \%$ & 10 \\
\hline Guatemala & 5 & $38 \%$ & 8 & $62 \%$ & 13 \\
\hline Paraguay & 11 & $65 \%$ & 6 & $35 \%$ & 17 \\
\hline Perú & 7 & $78 \%$ & 2 & $22 \%$ & 9 \\
\hline Venezuela & 13 & $54 \%$ & 11 & $46 \%$ & 24 \\
\hline
\end{tabular}

Source: Luis B Mejía, 2014

\subsection{Conversion mode of organizational change}

According to Thelen, institutions cannot be taken for granted. They are open to interpretation and subject to degrees of enforcement. Therefore, compliance and enforcement are key aspects in understanding organizational change. The interaction between the extent of compliance with the political context surrounding the agency, particularly the existence of veto points, enables one of four possible modes of institutional change: layering, drift, displacement and conversion.

Conversion takes place when existing organizations are strategically redirected to new goals, functions or purposes. The planning bodies came to life during the late1950s in response to a development strategy that required the state to provide long-term direction to economic development by means of economic planning. Across five decades, the same agencies have been redeployed, shaped and reconfigured to serve the purposes of alternative, sometimes opposite, development strategies.

Following Thelen, the confluence of low veto possibilities against those trying to change the agency with high levels of discretion in the interpretation/enforcement of the agency's mandates provide the setting in which it is more likely for a conversion mode of organizational change to occur. This research has found evidence in Argentina, Ecuador, Chile and Colombia of the existence of a strong 
presidential system in which the head of the state confronts weak veto possibilities to rearrange the administrative structure of the public sector. Likewise, data shows a commonality in the four countries in terms of the high ambiguity in the interpretation of the planning agencies' mandates. Combined, both of these variables have permitted the right setting surrounding the planning agencies to explain their fifty years of transformations as a conversion mode of organizational change.

However, what is the rationale for Presidents to influence the course of action taken by the planning agencies? In this respect, it is important to refer back to Thelen's remark in terms that actors driving change may or may not have transformational motives or, in other words, that transformations may not respond to an explicit or intentional motivation. This is the case for the evidence found in Argentina, Ecuador, Chile and Colombia. While Presidents have been the main actor responsible for the evolving role of the central planning agencies, they have not always actively sought to preserve or change the planning agency. Instead, they act in an opportunistic manner and depending on the circumstances and historical moments they use the planning agency in ways that better suit their interests, depending on the circumstances and historical moments. In this process, Presidents have either prompted transformations of the planning agency or contributed toward the agency's isolation and organizational inertia.

The research finds that the planning agencies have been useful to the President in at least four situations:

(i) The need to mobilize resources coming from foreign aid

In the four countries studied, Presidents first saw the opportunity in establishing planning agencies when the Alliance for Progress and later on the International Bank for Reconstruction and Development-IBRD (World Bank) started requiring countries to set up a planning agency and construct a national development plan, as a conditionality to access external aid and obtain technical assistance.

By the late-1960s, Presidents in these four countries had fulfilled their commitment made in Punta del Este. As table 21 depicts, the central planning agency was in motion and at least one national development plan had been created.

These plans were infrequently used as a basis for economic policy making and appear to constitute a diplomatic maneuver for attracting foreign capital. From that moment on, all four countries specifically included the coordination of international aid as one of the functions granted to the planning offices. 
Table 21

The Planning Agencies and the Alliance for Progress

\begin{tabular}{|c|c|c|c|c|c|}
\hline Year & Country & President & Planning body & $\begin{array}{c}\text { National } \\
\text { Development } \\
\text { Plan }\end{array}$ & $\begin{array}{c}\text { Loans and } \\
\text { grants } \\
\text { announced } \\
\text { in early } \\
1963\end{array}$ \\
\hline $\begin{array}{l}1963- \\
1966\end{array}$ & Argentina & Arturo Illia & CONADE & $\begin{array}{l}\text { National } \\
\text { Development } \\
\text { Plan 1965-1969 }\end{array}$ & $\begin{array}{l}\text { \$59.7 } \\
\text { million }\end{array}$ \\
\hline $\begin{array}{l}1958- \\
1964\end{array}$ & Chile & $\begin{array}{l}\text { Jorge } \\
\text { Alessandri }\end{array}$ & ODEPLAN & $\begin{array}{l}\text { National } \\
\text { Economic } \\
\text { Development } \\
\text { Program (1961- } \\
1970)\end{array}$ & $\begin{array}{l}\$ 40.4 \\
\text { million }\end{array}$ \\
\hline $\begin{array}{l}1962- \\
1966\end{array}$ & Colombia & $\begin{array}{l}\text { Guillermo } \\
\text { Leon } \\
\text { Valencia }\end{array}$ & $\begin{array}{l}\text { Administrative } \\
\text { Department of } \\
\text { Planning and } \\
\text { Technical } \\
\text { Services }\end{array}$ & $\begin{array}{l}\text { General } \\
\text { Economic and } \\
\text { Social } \\
\text { Development } \\
\text { Plan and Ten } \\
\text { Year } \\
\text { Development } \\
\text { Plan }\end{array}$ & $\begin{array}{l}\$ 72.3 \\
\text { million }\end{array}$ \\
\hline $\begin{array}{l}1963- \\
1966\end{array}$ & Ecuador & $\begin{array}{l}\text { Military } \\
\text { Junta }\end{array}$ & $\begin{array}{l}\text { National Board } \\
\text { of Economic } \\
\text { Planning and } \\
\text { Coordination }\end{array}$ & $\begin{array}{l}\text { First Social and } \\
\text { Economic } \\
\text { General } \\
\text { Development } \\
\text { Plan (1964- } \\
\text { 1973) }\end{array}$ & $\$ 5.3$ million \\
\hline
\end{tabular}

Source: Taffet, 2007

In Colombia, for example, practically each incoming government has implemented a strategic policy program financed by the World Bank and/or the Interamerican Development Bank on the condition that the National Planning Department undertakes the technical design and supervision of the program.

(ii) The need to veto projects from politically powerful ministers and control the spending appetite of the line ministers

Starting in the late-1970s and throughout the 1980s, Chile and Colombia created mechanisms inside the planning agency to filter and prioritize the spending proposals coming from the line ministries. By means of these project prioritization tools, governments could rationalize the national budget and provide technical viability to public investment projects. 
Specifically, ODEPLAN in Chile under President Pinochet created an investment project bank and designed criteria for undertaking economic and social evaluation of all governments' investment projects (cost benefit analysis). This meant that all ministries and other public organizations had to submit their investment projects to ODEPLAN for approval prior to sending them to the Ministry of Finance. In similar ways, through Law 38 of 1989, President Barco in Colombia allotted the planning agency with the task of allocating the country's investment resources, leading to the creation of the National Investment Project Bank inside of the planning agency. Within that bank, all investment projects that were to be financed with resources from the national budget had to be registered and pass a socio-economic (technical) valuation. The investment project banks in Colombia and Chile continue in place today.

(iii) The need to provide President with technical justifications and legitimacy

Supported by the work conducted in the planning agencies, Presidents have sought to remain popular and strengthen their legitimacy by using national plans to explain how national goals and economic growth can be achieved. For example, the military regime of Ongania in Argentina used the agency to harmonize economic development and national security to provide an institutionalized procedure for the military to justify measures of political control based on economic growth proposals (i.e. economic decision making was not consulted with labor unions).

Similarly, in Ecuador, the Military Junta in 1972-1979 found in the National Board of Economic Planning and Coordination a place to provide content to its nationalistic approach to development. In their drive to expand the state intervention in the economy, the development plan provided the President with the framework and tools for setting subsidies and welfare benefits and creating state-owned enterprises across various economic sectors.

In Colombia, President Uribe provides an example from a different angle. He was a very acute politician and as such had a certain disdain for the technocracy. However, when he had to respond to accountability inquiries from factions of Congress, he backed up his argument by stating that all budgetary allocations had been assigned with technical criteria stated in the national development plan.

(iv) The need to provide Presidents with accurate information and control Common to the origin of all planning agencies was the recruitment of qualified staff, the creation of systems and quantitative tools for policy analysis, aspects that were not only collaboratively financed by the international organizations but 
actually promoted. The international organizations needed an agency that could "do things right". Over the years, a stock of information and data was accumulated and consolidated in these agencies, more so than in any other agency, thus becoming a valuable resource for the President's office to design their priority policies. While turnover of staff at the planning agency occurred; for instance, it was not uncommon for Presidents such as Allende and Pinochet in Chile or the Military Juntas in Argentina to replace directives and general staff from the planning office, they did not destroy or dismiss the data. On the contrary, the information was used toward various different ends.

Likewise, the tentacles of the planning agency across the public sector have historically granted Presidents with an across-the-board control-point and influence of the public sector, whether through the establishment of satellite planning dependencies inside line ministries, regional and municipal planning offices or through the appointment of the head of the planning agency in the boards of other public agencies. With the possible exception of Chile, the planning agency in today's structure of the public sector in Argentina, Colombia and Ecuador is still the agency with the largest connections to the rest of the public bureaus.

\subsection{Conclusion}

This Chapter highlights that the presidential system of government that has characterized Argentina, Ecuador, Chile and Colombia, and the structural arrangement of central planning agencies, together allowed for what Mahoney and Thelen (2010) identify as a "conversion" mode of institutional change. Despite external shocks and pressures having been powerful stimuli for changes in the organizational arrangements of the planning body in these countries, organizational transformations have consistently been the result of sixty years of Presidents' redeployment of the goals, functions and purposes of the planning body. 


\section{Chapter 11: Conclusions}

This research builds upon the notions of organizational conversion in historical institutionalism by proposing that even though organizational change in the planning organizations studied has been animated by the two logics of action, namely consequentiality and appropriateness ${ }^{170}$, described in Chapter three, the historical change observed in such organizations has evolved from the gaps between the organization and its interpretation and the organization and its enforcement.

The Presidents of Argentina, Ecuador, Chile and Colombia have played a major role in shaping the structure of public administration in their countries. Either through executive action (executive orders or reorganization plans) or by delegated faculties, Presidents have influenced the structure of the state's public bureaus, including the central planning organizations, by creating, transforming or dismantling administrative agencies as well as rearranging functions within bureaucracy. Much of this influence comes from the presidential power to veto legislation and the executive right to introduce legislative proposals in certain policy areas, particularly in the creation of new bureaucratic offices. This authority of creating, transforming and terminating administrative agencies has not faced effective veto points. As the historical narratives suggest, there have not been strong actors with access to institutional or extra-institutional means of blocking the presidential will of organizational change. This situation, combined with the fact that the legal mandates and functions of the central planning agencies leave many details unspecified, has allowed the executive substantial discretion in transforming the structural arrangement of the planning agency. Through the redeployment of the goals, functions and purposes of the planning organization, the planning agencies have been converted in ways unanticipated by their designers. Historically, Presidents in Argentina, Ecuador, Colombia and Chile have adopted a wait-and-see approach that better suited their interests, becoming the main agent of endogenous organizational change within this process.

The case studies analyzed in this research elucidate some lessons that can feed the field of research on organizational change in Latin America. First, the cases show that the end of one organizational path and the transition to another can be initiated by both exogenous and endogenous sources. In other words, it is not always necessary that a critical juncture disturbs the organizational equilibrium to force an organizational transformation. The cases of Argentina and Ecuador show

\footnotetext{
${ }^{170}$ Under the logic of consequentiality, organizations are seen as an instrument to pursue specific goals. Below the logic of appropriateness, public organizations are understood as the reflection of what is perceived as modern, rightful, expected and legitimate.
} 
how critical junctures set in motion a series of events that led to agency transformation, but also indicate that subsequent changes occurred in the absence of specific breaking points. On the other hand, the cases of Colombia and Chile (at least after the return of democracy) show how an organizational path switchover gradually resulted from endogenous factors and without a contingent event. Second, it is very important not to underestimate the influence that Presidents in Latin America have in the structure of the public sector; the bias of the literature on agency creation and change towards Congress is of little applicability in the region, particularly given the unique Constitutional powers that Presidents have.

Findings in this research, contribute to better understanding the dynamics of institutional change in contexts different from the advanced industrialized democracies were the bulk of empirical testing of the theoretical approaches on institutional change have been conducted. While in these countries, institutions are more mature and long-time rooted, in the Latin American context institutions are more volatile. Very few studies have implemented a historical empirical account to test such theories in this context, making this research pioneering. Findings show that when these theories are tested in the context of Latin America, institutional change does not unfold in the rather antagonist ways, abrupt or continuous, but rather both forms of change are present. The planning offices studied all traversed abrupt episodes of transformation often preceded by critical junctures. But in between these abrupt changes, the agencies experienced continuous and gradual transformations all throughout their history. The historical character of this study was essential to reach to this conclusion because it permitted looking at the social processes around the planning agency's evolution as they unfolded, rather than looking at single moments of change in isolation.

Future research to complement findings of this study is welcomed. First, the transversal characteristic, inherent to the planning bodies since their inception, is quite unique to this organization. Central banks, sectoral ministries, departments, administrative and regulatory agencies and subnational agencies tend to cluster around a particular sector, region or policy of interest. It would be enlightening to understand the sources driving change in such type of organizations over an extended period of time, whether Presidents also represent an important role in the institutional transformations, and if so, the rationale at play for Presidents to intervene in the organization's course of action. Second, this research could be extended toward other countries in the region that implemented a parliamentary system of government, like the Caribbean countries, where the President is granted with fewer Constitutional powers, to gain knowledge on factors driving organizational change in such a system. Finally, another question that still needs resolution and thus calls for further investigation is to better understand why 
agents, other than the Presidents, are passive observers of the institutional switchover of the planning bodies. Is it the agency itself that has little appeal to other actors? Do other actors interact differently vis a vis other public bureaus? Under what circumstances would other actors be willing/capable of imposing their veto powers to protect/transform an agency?

The contribution made by Thelen and her collaborators on gradual and endogenous organizational change is insightful as it alerts the researcher to lay eyes on types of organizational change that depart from the punctuated equilibrium models. By calling attention to two explanatory variables (veto points and rule discretion) as well as the likelihood scenario in which four modes of gradual organizational change might be expected (layering, drift, displacement and conversion), Thelen provides hands-on tools and language as to the empirical evidence that the researcher should seek for. However, further research is needed to better draw the divisor line among these four modes of gradual change, as in practice the researcher may encounter particular outcomes that could possibly fit in more than one category. This research concluded that conversion was the mode of organizational change that better described the 50 years of transformations in the central planning offices studied, but at certain times in history outcomes could have been interpreted as a different mode of gradual change. For example in Colombia, the subsequent additions of each incoming President assigning the planning agency with its "flag" program could be interpreted to fall under the definition of layering (new rules are introduced on top of or alongside existing ones). Thus a stronger delimitation of boundaries among modes of gradual change would be of great benefit.

In a similar line of thought, Levitsky and Murillo (2010) call attention to conditions whereby under a weak institutional environment, a third strand of institutional change referred as serial replacement may occur. Serial replacement falls midground between punctual equilibrium models and gradual institutional change. Rather than being infrequent and radical or ongoing and gradual, institutional change is characterized as frequent and radical. Future empirical research in public agencies of countries like Argentina and Ecuador that historically have confronted a weak institutional environment (e.g multiple coups d'état; frequent constitutional amendments; massive turnover) is necessary to explore whether Levitsky and Murillo's mode of transformation finds solid ground in the data. The point is that empirical research on institutional change, whether in Latin America or even in other settings could greatly benefit from a sharper and explicit delimitation of typologies of institutional change. 
This research relied on process tracing as a methodological tool which has its strengths and weaknesses. The main advantage of this methodology is that it allows understanding, in larger depth, the mechanics and assembly of elements linking a theorized variable with a given outcome. This research has explored the black box of change in the planning agencies by reconstructing fifty years of the events and rationales surrounding agency transformations. Five theoretical approaches to understanding institutional change were unsurfaced. Only the on the ground process tracing of the observable implications of the causal mechanisms, allowed to weight-out the various theories and conclude that conversion, under the tutelage of the President, was the explanation that best accounted for fifty years of organizational change. As noted earlier, other theories of organizational change did influence the institutional trajectory taken by the planning bodies, but only the process tracing methodology provided the elements to assess that consistency of these other explanations was not evidenced throughout the studied period but only in isolated specific moments. In other words, they accounted, in one or another moment, and in one or another country, as a necessary but not sufficient explanation. Had the traditional correlation analysis been conducted, probably results would point at $X$ explaining $Y$ but they would hardly provide an explanation of how the causal forces were transmitted, whether they were consistently present and operating as expected.

One of the limitations of the methodology used is that it is case specific. Although the secondary data in countries, other than the ones were fieldwork was conducted, shows a similar trend to the one found in the case studies, results are not generalizable as evidence that is meaningful in one case is not necessarily meaningful in another case. This research was able to draw comparisons among Argentina, Ecuador, Chile, and Colombia, only because the historical narratives permitted noticing certain commonalities. However, given that the idiosyncrasy, economic and political context, and administrative structure of the public sector surrounding each country is unique, findings of this research are hard to generalize to other countries in the Latin American region, and almost impossible to stretch to planning offices in Europe (e.g. Iceland, Netherlands), Africa (e.g. Nigeria, Kenya) and Asia (e.g. India).

Another shortfall of the process tracing method in this study is that one of the sources to account for evidence of the observable implications of the causal mechanisms was based on interviews. Besides the natural bias that individuals may have when providing their testimonies, there may be lapses in memory, especially when events of interest took place many years earlier. The research mitigated this shortage by triangulating various sources of data. 


\section{Appendix 1: Central Planning Offices in Latin America and the Caribbean - 1960s}

\begin{tabular}{|c|c|c|}
\hline Country & Planning body & Year \\
\hline Argentina & $\begin{array}{l}\text { Consejo Nacional de Desarrollo de la Nación (National } \\
\text { Development Council, Presidency of the Nation) }\end{array}$ & 1961 \\
\hline Barbados & Planning Unit, Ministry of Finance & 1963 \\
\hline Bolivia & $\begin{array}{l}\text { Secretaría Nacional de Planificación y Coordinación (Nacional } \\
\text { Secretariat of Planning and Coordination) }\end{array}$ & 1961 \\
\hline Brazil & Ministerio de Planejamento (Ministry of Planning) & 1962 \\
\hline Chile & $\begin{array}{l}\text { Oficina de Planeación Nacional, Presidencia de la República } \\
\text { (Central Planning Office, Presidency of the Republic) }\end{array}$ & 1967 \\
\hline Colombia & $\begin{array}{l}\text { Departamento de Planeación y Servicios Técnicos } \\
\text { (Department of Planning and Technical Services) }\end{array}$ & 1958 \\
\hline Costa Rica & $\begin{array}{l}\text { Oficina de Planeación, Presidencia de la República (Planning } \\
\text { Office, Presidency of the Republic) }\end{array}$ & 1963 \\
\hline Cuba & Junta Central de Planificación (Central Planning Board) & 1959 \\
\hline $\begin{array}{l}\text { Dominican } \\
\text { Republic }\end{array}$ & $\begin{array}{l}\text { Junta Nacional de Planificación y Coordinación (National } \\
\text { Planning and Coordination Board) }\end{array}$ & 1962 \\
\hline Ecuador & $\begin{array}{l}\text { Junta Nacional de Planificación y Coordinación Económica, } \\
\text { Presidencia de la República (National Board of Planning and } \\
\text { Economic Coordination, Presidency of the Republic) }\end{array}$ & 1954 \\
\hline El Salvador & $\begin{array}{l}\text { Consejo Nacional de Planificación y Coordinación Económica } \\
\text { (National Council of Planning and Economic Coordination) }\end{array}$ & 1962 \\
\hline Guatemala & $\begin{array}{l}\text { Consejo Nacional de Planificación Económica (National } \\
\text { Council of Economic Planning) }\end{array}$ & 1954 \\
\hline Haiti & $\begin{array}{l}\text { Commissariat Nacional de Développement et de Planification } \\
\text { (National Development and Planning Commission) }\end{array}$ & 1962 \\
\hline Honduras & Consejo Nacional de Economía (National Economic Council) & 1956 \\
\hline Jamaica & Central Planning Unit & 1955 \\
\hline Mexico & Secretaria de la Presidencia (Secretariat of the Presidency) & 1976 \\
\hline Nicaragua & $\begin{array}{l}\begin{array}{l}\text { Oficina de Planificación Económica de la Presidencia } \\
\text { (Economic Planning Office) }\end{array} \\
\end{array}$ & 1962 \\
\hline Panamá & $\begin{array}{l}\text { Departamento de Planificación, Dirección General de } \\
\text { Planificación y Administración, Presidencia de la República } \\
\text { (Department of Planning, Directorate of Planning and } \\
\text { Administration, Presidency of the Republic) }\end{array}$ & 1956 \\
\hline Paraguay & $\begin{array}{l}\text { Secretaría Técnica de Planificación del Desarrollo Económico y } \\
\text { Social de la Presidencia de la República (Technical Secretariat } \\
\text { of Planning for Economic and Social Development }\end{array}$ & 1962 \\
\hline Peru & $\begin{array}{l}\text { Instituto Nacional de Planificación, (National Planning } \\
\text { Institute) }\end{array}$ & 1962 \\
\hline $\begin{array}{l}\text { Trinidad and } \\
\text { Tobago }\end{array}$ & $\begin{array}{l}\text { Town and country planning department, Prime Minister's } \\
\text { Office }\end{array}$ & 1960 \\
\hline
\end{tabular}




\begin{tabular}{|c|l|c|}
\hline Country & \multicolumn{1}{|c|}{ Planning body } & Year \\
\hline Uruguay & $\begin{array}{l}\text { Comisión de Inversiones y Desarrollo Económico (Investment } \\
\text { and Economic Development Commission) }\end{array}$ & 1960 \\
\hline Venezuela & $\begin{array}{l}\text { Oficina Central de Coordinación y Planificación, Presidencia } \\
\text { de la República (Central Office of Planning and Coordination, } \\
\text { Presidency of the Republic) }\end{array}$ & 1958 \\
\hline
\end{tabular}

Source: Luis B Mejía, 2014 based on Waterston, 1966 


\section{Appendix 2: Central Planning Offices in Latin America and the Caribbean - 2010}

\begin{tabular}{|c|c|c|c|}
\hline Country & $\begin{array}{l}\text { Central } \\
\text { planning } \\
\text { agency }\end{array}$ & Organizational changes & $\begin{array}{c}\text { Administrative } \\
\text { design }\end{array}$ \\
\hline Argentina & $\begin{array}{l}\text { Ministerio de } \\
\text { Planificación } \\
\text { Federal, } \\
\text { Inversión } \\
\text { Pública y } \\
\text { Servicios }\end{array}$ & $\begin{array}{l}1953 \text { Consejo Nacional de } \\
\text { Planificación } \\
1961 \text { Consejo Nacional de } \\
\text { Desarrollo de la Nación } \\
\text { (CONADE) } \\
1971 \text { Secretaría de Planeamiento y } \\
\text { Acción de Gobierno } \\
1973 \text { Instituto Nacional de } \\
\text { Planificación Económica. } \\
1978 \text { Secretaria de Planeamiento } \\
2003 \text { Ministerio de Planificación } \\
\text { Federal, Inversión Pública y } \\
\text { Servicios }\end{array}$ & Ministry \\
\hline Bolivia & $\begin{array}{l}\text { Ministerio de } \\
\text { Planificación } \\
\text { del Desarrollo }\end{array}$ & $\begin{array}{l}1961 \text { Junta Nacional de } \\
\text { Planemiento } \\
1974 \text { Secretaria Nacional de } \\
\text { Planificación y Coordinación } \\
1977 \text { Ministerio de Planeción y } \\
\text { Coordinación } \\
1999 \text { Ministerio de Desarrollo } \\
\text { Sostenible y Planificación } \\
\text { 2006 Ministerio de Planificación } \\
\text { del Desarrollo }\end{array}$ & Ministry \\
\hline Brazil & $\begin{array}{l}\text { Ministerio do } \\
\text { planejamento, } \\
\text { orcamento e } \\
\text { gestao }\end{array}$ & $\begin{array}{l}1962 \text { Ministério de Planejamento } \\
1967 \text { Ministério do Planejamento e } \\
\text { Coordenação } \\
1974 \text { Secretaria do Planejamento } \\
\text { SEPLAN } \\
1992 \text { Secretaria de Planejamento, } \\
\text { Orçamento e Coordenação da } \\
\text { Presidência da República } \\
1995 \text { Ministério do Planejamento e } \\
\text { Orçamento } \\
\text { 1999 Ministério do Planejamento, } \\
\text { Orçamento e Gestão }\end{array}$ & Ministry \\
\hline Chile & $\begin{array}{l}\text { Ministerio de } \\
\text { planificación } \\
\text { nacional } \\
\text { (MIDEPLAN) }\end{array}$ & $\begin{array}{l}1965 \text { Oficina de Planificación } \\
\text { (ODEPLAN) } \\
1990 \text { Ministerio de Planificación y } \\
\text { Cooperación (MIDEPLAN) }\end{array}$ & Ministry \\
\hline
\end{tabular}




\begin{tabular}{|c|c|c|c|}
\hline Country & $\begin{array}{l}\text { Central } \\
\text { planning } \\
\text { agency }\end{array}$ & Organizational changes & $\begin{array}{c}\text { Administrative } \\
\text { design }\end{array}$ \\
\hline Colombia & $\begin{array}{l}\text { Departamento } \\
\text { Nacional de } \\
\text { Planeación }\end{array}$ & $\begin{array}{l}1958 \text { Consejo Nacional de Política } \\
\text { Económica y Planeación } \\
1958 \text { Departamento } \\
\text { Administrativo de Planeación y } \\
\text { Servicios Técnicos } \\
1968 \text { Departamento Nacional de } \\
\text { Planeación }\end{array}$ & $\begin{array}{l}\text { Department } \\
\text { (ministry) }\end{array}$ \\
\hline Costa Rica & $\begin{array}{l}\text { Ministerio de } \\
\text { Planificación } \\
\text { nacional y } \\
\text { política } \\
\text { económica } \\
\text { (MIDEPLAN) }\end{array}$ & $\begin{array}{l}1963 \text { Oficina de Planificación de la } \\
\text { Presidencia de la República } \\
1974 \text { Oficina de Planificación } \\
\text { Nacional y Política Económica } \\
\text { (OFIPLAN) } \\
\text { 1982 Ministerio de Planificación } \\
\text { Nacional y Política Económica } \\
\text { (MIDEPLAN) }\end{array}$ & Ministry \\
\hline Cuba & $\begin{array}{l}\text { Ministerio de } \\
\text { Economía y } \\
\text { Planificación } \\
\end{array}$ & $\begin{array}{l}1960 \text { Junta Central de } \\
\text { Planificación } \\
1962 \text { Ministerio de Planificación }\end{array}$ & Ministry \\
\hline $\begin{array}{l}\text { Dominican } \\
\text { Republic }\end{array}$ & $\begin{array}{l}\text { Secretaría de } \\
\text { Estado de } \\
\text { Economía, } \\
\text { Planificación y } \\
\text { Desarrollo }\end{array}$ & $\begin{array}{l}\text { 1962 Junta Nacional de } \\
\text { Planificación y Coordinación } \\
1965 \text { Oficina Nacional de } \\
\text { Planificación } \\
2006 \text { Secretaría de Estado de } \\
\text { Economía, Planificación y } \\
\text { Desarrollo (SEEPYD) }\end{array}$ & Ministry \\
\hline Ecuador & $\begin{array}{l}\text { Secretaria } \\
\text { nacional de } \\
\text { planificación y } \\
\text { desarrollo }\end{array}$ & $\begin{array}{l}1954 \text { Junta Nacional de } \\
\text { Planificación y Coordinación } \\
\text { Económica (Junapla) } \\
1979 \text { Consejo Nacional de } \\
\text { Desarrollo (CONADE) } \\
1998 \text { Oficina de Planificación } \\
\text { (ODEPLAN) } 2004 \text { Secretaría } \\
\text { Nacional de Planificación y } \\
\text { Desarrollo (SENPLADES) }\end{array}$ & $\begin{array}{l}\text { Technical entity } \\
\text { under the } \\
\text { Presidency of } \\
\text { the Republic }\end{array}$ \\
\hline Guatemala & $\begin{array}{l}\text { Secretaria de } \\
\text { Planificación y } \\
\text { Programación } \\
\text { de la } \\
\text { Presidencia } \\
\text { (SEGEPLAN) }\end{array}$ & $\begin{array}{l}\text { 1954 Consejo Nacional de } \\
\text { Planificación Económica } \\
1954 \text { Secretaria de Planificación y } \\
\text { Programación de la Presidencia } \\
\text { (SEGEPLAN) }\end{array}$ & $\begin{array}{l}\text { Technical entity } \\
\text { under the } \\
\text { Presidency of } \\
\text { the Republic }\end{array}$ \\
\hline Haiti & $\begin{array}{l}\text { Ministère de la } \\
\text { Planification et } \\
\text { de la }\end{array}$ & $\begin{array}{l}1962 \text { le Conseil National de } \\
\text { Développement et de } \\
\text { Planification (CONADEP) }\end{array}$ & Ministry \\
\hline
\end{tabular}




\begin{tabular}{|c|c|c|c|}
\hline Country & $\begin{array}{l}\text { Central } \\
\text { planning } \\
\text { agency }\end{array}$ & Organizational changes & $\begin{array}{c}\text { Administrative } \\
\text { design }\end{array}$ \\
\hline & $\begin{array}{l}\text { Copération } \\
\text { Externe } \\
\text { (Ministry of } \\
\text { Planning and } \\
\text { External } \\
\text { Cooperation) }\end{array}$ & $\begin{array}{l}1968 \text { Commissariat National de } \\
\text { Développement et de } \\
\text { Planification } \\
1978 \text { Ministère du Plan } \\
1986 \text { Commissariat à la Promotion } \\
\text { Nationale et à l'Admnistration } \\
\text { Publique } 1989 \text { Ministère de la } \\
\text { Planification et de la Coopération } \\
\text { Externe }\end{array}$ & \\
\hline Nicaragua & $\begin{array}{l}\text { Consejo } \\
\text { Nacional de } \\
\text { Planificación } \\
\text { Económica y } \\
\text { Social } \\
\text { (CONPES) }\end{array}$ & $\begin{array}{l}1962 \text { Oficina de Planificación } \\
\text { Económica } \\
1971 \text { Oficina Nacional de } \\
\text { Planificación } \\
1985 \text { Consejo Nacional de } \\
\text { Planificación } \\
1999 \text { Consejo Nacional de } \\
\text { Planificación Económica y Social } \\
\text { (CONPES) }\end{array}$ & $\begin{array}{l}\text { Collegial body } \\
\text { of government } \\
\text { (Council). } \\
\text { Executive } \\
\text { branch of } \\
\text { government }\end{array}$ \\
\hline Paraguay & $\begin{array}{l}\text { Secretaría } \\
\text { Técnica de } \\
\text { Planificación } \\
\text { del Desarrollo } \\
\text { Económico y } \\
\text { Social de la } \\
\text { Presidencia de } \\
\text { la República }\end{array}$ & $\begin{array}{l}1962 \text { Secretaria Técnica de } \\
\text { Planificación del Desarrollo } \\
\text { Económico y Social }\end{array}$ & $\begin{array}{l}\text { Technical } \\
\text { Secretariat }\end{array}$ \\
\hline Peru & $\begin{array}{l}\text { Centro } \\
\text { Nacional de } \\
\text { Planeamiento } \\
\text { Estratégico } \\
\text { (CEPLAN) }\end{array}$ & $\begin{array}{l}1962 \text { Instituto Nacional de } \\
\text { Planificación } \\
1981 \text { Sistema Nacional de } \\
\text { Planificación-Instituto Nacional } \\
\text { de Planificación } \\
1992 \text { INPE eliminated } \\
2005 \text { Centro Nacional de } \\
\text { Planeamiento Estratégico } \\
\text { (CEPLAN) }\end{array}$ & $\begin{array}{l}\text { Collegial body } \\
\text { of government } \\
\text { (Council). } \\
\text { Executive } \\
\text { branch of } \\
\text { government }\end{array}$ \\
\hline Uruguay & $\begin{array}{l}\text { Oficina de } \\
\text { Planeamiento y } \\
\text { Presupuesto }\end{array}$ & $\begin{array}{l}1960 \text { Comisión de Inversiones y } \\
\text { Desarrollo Económico (CIDE) } \\
1967 \text { Oficina de Planeamiento y } \\
\text { Presupuesto } \\
1976 \text { Secretaría de Planeamiento, } \\
\text { Coordinación y Difusión } \\
\text { (SEPLACODI) } \\
1985 \text { Oficina de Planeamiento y }\end{array}$ & $\begin{array}{l}\text { Technical entity } \\
\text { under the } \\
\text { Presidency of } \\
\text { the Republic }\end{array}$ \\
\hline
\end{tabular}




\begin{tabular}{|c|c|c|c|}
\hline Country & $\begin{array}{l}\text { Central } \\
\text { planning } \\
\text { agency }\end{array}$ & Organizational changes & $\begin{array}{c}\text { Administrative } \\
\text { design }\end{array}$ \\
\hline & & Presupuesto (OPP) & \\
\hline Venezuela & $\begin{array}{l}\text { Ministerio del } \\
\text { Poder Popular } \\
\text { para la } \\
\text { Planificación y } \\
\text { el Desarrollo }\end{array}$ & $\begin{array}{l}1958 \text { Oficina Central de } \\
\text { Coordinación y Planificación de la } \\
\text { Presidencia de la República } \\
2007 \text { Ministerio del Poder Popular } \\
\text { para la Planificación y el } \\
\text { Desarrollo }\end{array}$ & Ministry \\
\hline
\end{tabular}

Source: Luis B Mejía, 2014 


\section{Appendix 3: List of secondary data reviewed}

\begin{tabular}{|c|c|c|c|c|}
\hline Country & $\begin{array}{c}\text { Press } \\
\text { articles }\end{array}$ & Policy documents & $\begin{array}{l}\text { Organizational } \\
\text { records }\end{array}$ & Legal instruments \\
\hline Argentina & $\begin{array}{l}\text { Clarín } \\
\text { La Nación }\end{array}$ & $\begin{array}{l}\text { First Five Year } \\
\text { Development Plan } \\
\text { Second Five Year } \\
\text { Development Plan } \\
\text { National } \\
\text { Development Plan } \\
\text { 1965-1969 } \\
\text { General } \\
\text { Development and } \\
\text { Security Plan 1968- } \\
\text { 1977 } \\
\text { National } \\
\text { Development and } \\
\text { Security Plan 1968- } \\
\text { 1972 }\end{array}$ & $\begin{array}{l}\text { Organizational } \\
\text { charts } \\
\text { Budgets }\end{array}$ & $\begin{array}{l}\text { Dec. } 7.2901961 \\
\text { Law } 16.964 \text { of } 1966 \\
\text { Dec. } 1.0571973 \\
\text { Law } 21.431 \text { of } 1977 \\
\text { Law } 21.909 \text { of } 1978 \\
\text { Law of Ministries of } \\
1983 \\
\text { Law of Ministries } \\
\text { 26.338 of } 2003 \\
\text { Dec. } 12832003\end{array}$ \\
\hline Chile & $\begin{array}{l}\text { La Tercera } \\
\text { Mercurio }\end{array}$ & $\begin{array}{l}\text { Six Year National } \\
\text { Economic Plan } \\
\text { 1971-1976 } \\
\text { National } \\
\text { Development } \\
\text { Indicative Plans } \\
\text { Ten Years } \\
\text { Government Plan } \\
(1989-1998)\end{array}$ & $\begin{array}{l}\text { Organizational } \\
\text { charts } \\
\text { Budgets }\end{array}$ & $\begin{array}{l}\text { Law } 16.635 \text { of } 1967 \\
\text { Dec. } 3031971 \\
\text { Dec. } 9661975 \\
\text { Law } N^{\circ} 18.989 \text { of } 1990\end{array}$ \\
\hline Colombia & $\begin{array}{l}\text { El Tiempo } \\
\text { Espectador } \\
\text { El Siglo }\end{array}$ & $\begin{array}{l}\text { National } \\
\text { Development Plan: } \\
\text { 1970-1974 } \\
1974-1978 \\
1978-1982 \\
9182-1986 \\
1986-1990 \\
1990-1994 \\
1994-1998 \\
1998-2002 \\
2002-2006 \\
2006-2010 \\
2010-\end{array}$ & $\begin{array}{l}\text { Organizational } \\
\text { charts } \\
\text { Budgets }\end{array}$ & $\begin{array}{l}\text { Law } 19 \text { of } 1958 \\
\text { Dec. } 0239 \text { of } 1959 \\
\text { Dec.- law } 3242 \text { of } 1963 \\
\text { Dec. } 29961968 \\
\text { Dec. } 9831972 \\
\text { Dec. } 294 \text { of } 1973 \\
\text { Dec. law } 6271974 \\
\text { Law } 38 \text { of } 1989 \\
\text { Dec. } 2410 \text { of } 1989 \\
\text { Dec. } 21671992 \\
\text { Dec. } 13632000 \\
\text { Dec. } 1602002 \\
\text { Dec. } 1952004 \\
\text { Dec. } 43552005 \\
\text { Dec. } 35172009\end{array}$ \\
\hline Ecuador & $\begin{array}{l}\text { Comercio } \\
\text { Hoy }\end{array}$ & $\begin{array}{l}\text { National Planning } \\
\text { Board-Annual }\end{array}$ & $\begin{array}{l}\text { Organizational } \\
\text { charts }\end{array}$ & $\begin{array}{l}\text { Emergency Decree } \\
\text { Law } 19 \text { of } 1954\end{array}$ \\
\hline
\end{tabular}




\begin{tabular}{|c|c|c|c|c|}
\hline Country & $\begin{array}{c}\text { Press } \\
\text { articles }\end{array}$ & Policy documents & $\begin{array}{c}\text { Organizational } \\
\text { records }\end{array}$ & Legal instruments \\
\hline & & $\begin{array}{l}\text { report 1954-1955 } \\
\text { National Planning } \\
\text { Board-The National } \\
\text { Development Plans } \\
\text { and its coordination } \\
\text { National Planning } \\
\text { Board-25 years of } \\
\text { national planning } \\
\text { 1955-1979 }\end{array}$ & Budgets & $\begin{array}{l}\text { Executive Decree } 120 \\
\text { of } 1998 \\
\text { Executive Decree } \\
1372 \text { of } 2004 \\
\text { Executive Decree } 103 \\
\text { of } 2007\end{array}$ \\
\hline
\end{tabular}

Source: Luis B Mejía, 2014 


\section{Appendix 4: Historical evolution of Argentina's Central Planning Agency Tasks}

\begin{tabular}{|c|c|}
\hline & $\begin{array}{l}\text { CONADE-INPE-Ministry of Planning-Secretary of Planning- Ministry of } \\
\text { Planning and Investment Services }\end{array}$ \\
\hline $\begin{array}{l}1960- \\
1970\end{array}$ & $\begin{array}{l}\text { Preparing the National Development Plan and the national accounts } \\
\text { Participating in the industrial policy making } \\
\text { Defining the short term investment budget, and the monetary, credit, and } \\
\text { exchange rate policies } \\
\text { Coordinate regional development }\end{array}$ \\
\hline $\begin{array}{l}1970- \\
1980\end{array}$ & $\begin{array}{l}\text { Preparing the National Development Plan } \\
\text { Preparing the National Investment Budget } \\
\text { Collaborating with the Finance Ministry on the privatization process } \\
\text { Development of tools to streamline public investment }\end{array}$ \\
\hline $\begin{array}{l}1980- \\
1990\end{array}$ & $\begin{array}{l}\text { Formulating medium-term policy goals } \\
\text { Drafting development plans, programs, economic and social projects. }\end{array}$ \\
\hline $\begin{array}{l}1990- \\
2000\end{array}$ & Drafting programs, plans and projects \\
\hline $\begin{array}{l}2000- \\
2010\end{array}$ & $\begin{array}{l}\text { Assisting in the design, implementation and regulation of public policies } \\
\text { related with transport, communications, mining, energy, sanitation, public } \\
\text { works, housing, water resources, and territorial development }\end{array}$ \\
\hline
\end{tabular}

Source: Luis B Mejía, 2014 


\section{Appendix 5: Historical evolution of Ecuador's Central Planning Agency Tasks}

\begin{tabular}{|c|c|}
\hline & JUNAPLA-CONADE-ODEPLAN-SENPLADES \\
\hline $\begin{array}{l}1960- \\
1970\end{array}$ & $\begin{array}{l}\text { Preparing projects for external financing } \\
\text { Conceptualizing on the setting of tariffs, taxes and fees } \\
\text { Formulating the preparation of the National Development Plan } \\
\text { Advising the public sector on issues related with the issuance of state } \\
\text { bonds }\end{array}$ \\
\hline $\begin{array}{l}1970- \\
1980 \\
\end{array}$ & Preparing studies on the Ecuadorian economy \\
\hline $\begin{array}{l}1980- \\
1990\end{array}$ & Formulating the preparation of the National Development Plan \\
\hline $\begin{array}{l}1990- \\
2000 \\
\end{array}$ & Providing guidance for public investment \\
\hline $\begin{array}{l}2000- \\
2010\end{array}$ & $\begin{array}{l}\text { term and annual national development plans } \\
\text { Evaluating the progress of the development plans } \\
\text { Negotiating the acquisition and coordination of foreign aid or credit } \\
\text { Participating in the budgetary process by targeting public investment. }\end{array}$ \\
\hline
\end{tabular}

Source: Luis B Mejía, 2014 


\section{Appendix 6: Historical evolution of Chile's Central Planning Agency Tasks}

\begin{tabular}{|c|c|}
\hline & ODEPLAN-MIDEPLAN-Ministry of Social Protection \\
\hline $\begin{array}{l}1960- \\
1970\end{array}$ & $\begin{array}{l}\text { Coordinating the preparation of the National Development Plan and the } \\
\text { economic policy making }\end{array}$ \\
\hline $\begin{array}{l}1970- \\
1980\end{array}$ & $\begin{array}{l}\text { Designing major reforms to prepare for a neoliberal development model } \\
\text { Developing tools to measure extreme poverty and target public investment } \\
\text { Creating a system to evaluate the efficiency of public spending }\end{array}$ \\
\hline $\begin{array}{l}1980- \\
1990\end{array}$ & Developing tools to streamline public investment \\
\hline $\begin{array}{l}1990- \\
2000\end{array}$ & $\begin{array}{l}\text { Coordinating social policies } \\
\text { Managing the National Investment System } \\
\text { Defining national guidelines for regional development }\end{array}$ \\
\hline $\begin{array}{l}2000- \\
2010\end{array}$ & $\begin{array}{l}\text { Coordinating the Social Protection System (elderly, children unprotected, } \\
\text { people with disability) }\end{array}$ \\
\hline
\end{tabular}

Source: Luis B Mejía, 2014 


\section{Appendix 7: Historical evolution of Colombia's Central Planning Agency Tasks}

\begin{tabular}{|c|c|}
\hline & $\begin{array}{c}\begin{array}{c}\text { Department of Planning and Technical Services - National Development } \\
\text { Plan }\end{array} \\
\end{array}$ \\
\hline $\begin{array}{l}1960- \\
1970\end{array}$ & $\begin{array}{l}\text { Coordinating the preparation of the National Development Plan and the } \\
\text { economic policy making } \\
\text { Preparing projects for external financing } \\
\text { Issuing its opinion on external loans requested by the country } \\
\text { Taking decisions over tariffs }\end{array}$ \\
\hline $\begin{array}{l}1970- \\
1980\end{array}$ & $\begin{array}{l}\text { Defining industrial protection policies } \\
\text { Participating in the sectoral public policy formulation } \\
\text { Reviewing and endorsing, both external and internal credit solicitations } \\
\text { made by the government } \\
\text { Issuing authorizations for direct foreign private investment } \\
\text { Conceptualizing on the procurement by other public organizations of } \\
\text { electronic calculation equipments }\end{array}$ \\
\hline $\begin{array}{l}1980- \\
1990\end{array}$ & $\begin{array}{l}\text { Guiding the level of state intervention in the economy } \\
\text { Deciding the level of public expenditure and investment } \\
\text { Defining the composition of the public investment } \\
\text { Allocating public investment } \\
\text { Participating in the sectoral public policy formulation }\end{array}$ \\
\hline $\begin{array}{l}1990- \\
2000\end{array}$ & $\begin{array}{l}\text { Directing the liberalization of the economy and opening of markets } \\
\text { Coordinating the decentralization process } \\
\text { Regulating the delivery by private enterprises of public services }\end{array}$ \\
\hline $\begin{array}{l}2000- \\
2010\end{array}$ & $\begin{array}{l}\text { Developing tools to streamline public investment } \\
\text { Defining the composition of the public investment } \\
\text { Allocating public investment }\end{array}$ \\
\hline
\end{tabular}




\begin{tabular}{|l|l|}
\hline & $\begin{array}{l}\text { Department of Planning and Technical Services - National Development } \\
\text { Plan }\end{array}$ \\
\hline Participating in the sectoral public policy formulation \\
Directing the state reform
\end{tabular}

Source: Luis B Mejía, 2014 


\section{References}

Álvarez Guerrero, Osvaldo (Comp.) (n.d) Arturo Illia. La Ortodoxia Republicana. Buenos Aires, CECIES -Pensamiento Latinoamericano y Alternativo. Retrieved from http://www.cecies.org/imagenes/edicion 164.pdf

Allende, Salvador (1972) "Segundo Mensaje Presidencial. El Sistema Nacional de Planificación."In: DOCUMENTOS DE SALVADOR ALLENDE. Su pensamiento, el homenaje y visiones diversas sobre su quehacer y papel histórico Documentos de la alianza que representó. Retrieved from

http://www.archivochile.com/S Allende UP/html/sallende doc de.html

Arceneaux, Craig (2001) Bounded Missions: Military Regimes and Democratization in the Southern Cone and Brazil. University Park: Pennsylvania State University Press

Archer, Ron and Matthew S. Shugart (1997) The Unrealized Potential of Presidential Dominance in Colombia." In: Presidentialism and Democracy in Latin America. New York: Cambridge University Press.

Ascher, William (1984) Scheming for the Poor: The Politics of Redistribution in Latin America. Cambridge: Harvard University Press

Benett, Andrew and Jeffrey Checkel (2012) "Process Tracing: From Philosophical Roots to Best Practices." In: Process Tracing in the Social Sciences: From Metaphor to Analytic Tool. Andrew Bennett and Jeffrey T. Checkel, Editors, forthcoming

Beach, Derek and Rasmus Brun Pedersen (2013) Process-Tracing Methods. Foundations and Guidelines. Ann Arbor: The University of Michigan Press

Boin, Arjen, Sanneke Kuipers and Narco Steenbergen (2010) "The Life and Death of Public Organizations: A Question of Institutional Design?" Governance, Volume 23, Issue 3,

Bonvecchi, Alejandro and Carlos Scartascini (2011) "The Presidency and the Executive Branch in Latin America: What We Know and What We Need to Know," Research Department Publications 4756. Washington: Inter-American Development Bank, Research Department

Botana, Natalio, Rafael Braun y Carlos Floria (1973) El régimen militar. 1966-1973. Buenos Aires: La Bastilla 
Bresser Pereira, Luiz Carlos and Peter Spink (1999) Reforming the State: Managerial Public Administration in Latin America. Boulder: Lynne Rienner Publishers

Bresser Pereira, Luiz Carlos (2011) "From Old to New Developmentalism in Latin America." In: The Handbook of Latin America Economics. Oxford: Oxford University Press

Caballero Argaez, Carlos and Cristina Vélez (2008) “Origenes y Antecedentes de la Planeación en Colombia" In: Cincuenta Años Departamento Nacional de Planeación. Bogotá: Departamento Nacional de Planeación

Caballero Argaez, Carlos (2008) "De los Años Sesenta a los Ochenta del Siglo XX. Reorganización del Departamento Nacional de Planeación" In: Cincuenta Años Departamento Nacional de Planeación. Bogotá: Departamento Nacional de Planeación

Cameron, Maxwell (2009) "Latin America's Left Turns: beyond good and bad," Third World Quarterly, Vol. 30, No. 2

Canelo, Paula (2004) "La Política Contra la Economía: Las Elecciones Militares Frente al Plan Económico de Martínez de Hoz durante el Proceso de Reorganización Nacional." In: Empresarios, Tecnócratas y Militares. La Trama Corporativa de la Última Dictadura. Buenos Aires: Siglo XXI.

Cano Motta, Augusto (1972) “El proceso de la planeación en Colombia. In: Lecturas Sobre Desarrollo Económico Colombiano. Bogota: FEDESARROLLO

Cano, Augusto (1978) Antecedentes Constitucionales y Legales de la Planeación en Colombia. In: Lecturas sobre Desarrollo Económico Colombiano. Bogotá: FEDESARROLLO

Cárdenas, Mauricio (2010) "State Capacity in Latin America." Economía. Volume 10, Number 2

Cardoso, Eliana (2009) "A Brief History of Trade Policies in Brazil: From ISI, Export Promotion and Import Liberalization to Multilateral and Regional Agreements." Paper prepared for the conference on "The Political Economy of Trade Policy in the BRICS" New Orleans

Castiglioni, Rossana (2001) "The Politics of Retrenchment: The Quandaries of Social Protection under Military Rule in Chile, 1973-1990", Latin American Politics and Society Vol. 43, No. 4 
Cavarozzi, Marcelo (1997) Autoritarismo y Democracia (1955-1996). La Transición del Estado al Mercado en la Argentina. Buenos Aires: Compañía Editora Espasa Calpe / Ariel

Cejudo, Guillermo (2007) “Critical Junctures or Slow-moving Process? The Effects of Political and Economic Transformations on the Mexican Public Sector". Revista Chilena de Administración Pública, $\mathrm{N}^{\circ} 10$

Centeno, Miguel A. and Patricio Silva (1998), eds. The Politics of Expertise in Latin America. Houndsmills: Macmillan

Cordone, Hector (2004) "Reseña Histórica sobre la Planificación en la Argentina". Documento CEIL-PIETTE

Checkel , Jeffrey (2009) "It's the Process Stupid! Process Tracing in the Study of European and International Politics." In: Qualitative Methods in International Relations: A Pluralist Guide. Syracuse: Palgrave Macmillan

Christensen, J. G. and Yesilkagit, K. (2006). "Delegation and Specialization in Regulatory Administration: A Comparative Analysis of Denmark, Sweden and the Netherlands". Paper prepared for the SOG and Scancor Workshop on Autonomization of the state: From integrated administrative models to single purpose organizations Scancor, Stanford University

Christensen and P. Lægreid (eds), Autonomy and Regulation. Coping with Agencies in the Modern State. Cheltenham: Edward Elgar

Christensen, T. and Laegreid, P. (2006). '"Agencification and Regulatory Reform". In: Autonomy and Regulation: Coping with Agencies in the Modern State. Cheltenham: Edward Elgar

Christensen, T. and Laegreid, P. (2007). "Regulatory Agencies - The Challenges of Balancing Agency Autonomy and Political Control", Governance, 20 (3)

Christensen, T. and M. Egeberg (1997) "Central Government - a Survey on the Characteristics of Ministries." In: Forvaltningskunnskap. Oslo: Tano Aschehoug

Chun, Young Han and Hal Rainey (2005) "Goal Ambiguity in U.S. Federal Agencies." Journal of Public Administration Research and Theory, Vol. 15, no. 1

Crisis Group (2007) Ecuador: Overcoming Instability? Latin America Report №22 - 7 
Dargent, Eduardo (2008) "Agents or Actors? Assessing the Autonomy of Economic Technocrats in Peru (1990-2008) and Colombia (1958-2008)". Paper presented at the annual meeting of the Midwest Political Science Association 67th Annual National Conference, The Palmer House Hilton, Chicago, IL, Apr 02, 2009

Denhardt, Robert (2008) Theories of Public Organization. Belmont: Thomson Wardsword

Departamento Nacional de Planeación (1983) La Planeación en Colombia 1958-1983. Bogotá: Departamento Nacional de Planeación

DiMaggio, Paul and Powell, W. W. (1983). “The Iron Cage Revisited: Institutional Isomorphism and Collective Rationality in Organizational Fields", American Sociological Review 48 (2)

DiMaggio, Paul (1987) "Nonprofit organizations in the production and distribution of culture". In: The nonprofit sector: Research handbook, ed. W. Powell. New Haven: Yale University Press

Dix, Robert (1987) The Politics of Colombia. New York: Hoover Institution-Praeger Publishers

Domínguez, Jorge (1997) "Technopols: Ideas and Leaders in Freeing Politics and Markets in Latin America in the 1990s", in: Freeing Politics and Markets in Latin America in the 1990s. University Park: Pennsylvania State University Press

Egan, Patrick (2010) "Hard Bargains: The Impact of Multinational Corporations on Economic Reform in Latin America." Latin American Politics and Society. Volume 52, Issue 1

Epstein, David, and Sharyn O'Halloran. (1999) Delegating Powers. A Transaction Costs Politics Approach to Policy Making under Separate Powers. Cambridge: Cambridge University press

Falconí, Fender (2011) “¿Por qué la SENPLADES?” El Telégrafo. Quito: noviembre

Feldman, Martha (1989) Order without design: Information production and policy making. Stanford: Stanford University Press 
Falleti, Tulia (2006) “Theory Guided Process Tracing: Something Old, Something New," APSA-CP, Newsletter of the Organized Section in Comparative Politics of the APSA, Volume 17, Issue 1

Ferreira Rubio, Delia and Matteo Goretti (2000) "Executive-Legislative relationship in Argentina: From Menem's Decretazo to a new style?" Argentina 2000: Politics, Economy, Society and International Relations. Annual conference. Oxford, May 15-17, 2000

Fiorina, Morris (1977) Congress. The Keystone of Washington Establishment. New Heaven, Yale University Press

Fiorina, Morris (1982) “Legislative Choice of Regulatory Forms: Legal Process or Administrative Process?" Public Choice 39

Florez, Luis Bernardo (2009) "Colombian Economics. Policy and Economists". Economist in the Americas. Cheltenham: Edward Elgar Publishing

Forteza, Alvaro and Mariano Tommasi (2005). "Understanding reform in Latin America." Working papers 2205, Universidad de San Andres, Departamento de Economia

García Bossio, Horacio (2008) Génesis del Estado Desarrollista Latinoamericano: el Pensamiento y la Praxis Política de Helio Jaguaribe (Brasil) y de Rogelio Frigerio (Argentina). Buenos Aires: Pontificia Universidad Católica- Departamento de Economía, Documento de Trabajo № 23

Geddes, Barbara (1990) "Building State Autonomy in Brazil, 1930-1964". Comparative Politics, Vol. 22, No. 2

Geddes, Barbara. (1996). Politician's Dilemma: Building State Capacity in Latin America. Berkeley: University of California.

George, Alexander and Andrew Bennett (2005) Case Studies and Theory Development in the Social Sciences. Cambridge: MIT press

Gerring, John (2007) Case Study Research. Principles and Practices. Cambridge: Cambridge University Press 
Gilardi, Fabrizio. (2002) "Policy Credibility and Delegation to Independent Regulatory Agencies: A Comparative Empirical Analysis", Journal of European Public Policy, 9 (6)

Glaser, Jeff and Anselm Strauss. (1967) The Discovery of Grounded Theory: Strategies for Qualitative Research. New York: Aldine de Gruyter

Goldberg, Peter (1975) "The Politics of the Allende Overthrow in Chile." Political Science Quarterly Vol. 90, No. 1

Grafton, C. (1979) "The Reorganization of Federal Agencies". Administration and Society 10

Grindle, Merilee, ed. (1997). Getting Good Government. Cambridge: Harvard University Press.

Grindle, Merilee (1996) Challenging the State: Crisis and Innovation in Latin America and Africa. Cambridge: Cambridge University Press

Grindle, Merilee, and Francisco Thoumi (1993) "Muddling Toward Adjustment: The Political Economy of Economic Policy Change in Ecuador." In: Political and Economic Interactions in Economic Reform. Evidence from Eight Countries: Cambridge: Blackwell Publishers

Haggard, Stephan (1986) "The Politics of Adjustment: Lessons from the IMF's Extended Fund Facility." In: The Politics of International Debt. Ithaca: Cornell University Press

Haggard, Stephan (1990) Pathways from the Periphery. The Politics of Growth in the Newly Industrializing Countries. Ithaca: Cornell University Press

Haggard, Stephan and Robert R. Kaufman eds. (1992) The Politics of Adjustment. Princeton: Princeton University Press

Haggard, Stephan, and Kaufman, R. R. (1995). The political economy of democratic transitions. Princeton: Princeton University Press

Haggard, Stephan and Sylvia Maxfield (1996) "The Political Economy of Financial Internationalization in the Developing World". International Organization 50(1) 
Han Chun, Young and Hal Rainey (2005) "Goal Ambiguity in U.S. Federal Agencies". Journal of Public Administration Research and Theory: Vol. 15, no. 1

Hartlyn, Jonathan (1988) The Politics of Coalitional Rule in Colombia. Cambridge: Cambridge University Press

Heredia, Blanca and Ben Ross Schneider (1998) "The Political Economy of Administrative Reform: Building State Capacity in Developing Countries." Political Science Department, Northwestern University. Mimeograph

Hey, Jeanne and Thomas Klak (1999) "From Protectionism Toward Neoliberalism: Ecuador Under Four Administrations (1981-1996)," Studies in Comparative International Development. Vol. 34, No. 3

Hirschman, Albert (1958) The strategy of economic development. New Haven: Yale University Press

Hirschman, Albert (1963) Journeys toward progress. New York: Twentieth Century Fund

Hommes, Rudolf (1996) "Evolution and Rationality of Budget Institutions in Colombia". Inter-American Development Bank, Working Papers

Horn, Murray J. (1995). The Political Economy of Public Administration. Cambridge: Cambridge University press

Horn, Murray and Keneth Shepsle (1989) "Commentary on Administrative Arrangements and the Political Control of Agencies: Administrative Process and Organizational form as Legislative Responses to Agency Costs", Virginia Law Review, vol 75

Howell, William, and David E Lewis (2002) "Agencies by Presidential Design". Journal of Politics 64

Huber, john and Charles R Shipan (2002) Deliberate discretion? The institutional foundations of bureaucratic autonomy. Cambridge: Cambridge University Press.

Huber, John, Charles R. Shipan and Madelaine Pfahler (2001). "Legislatures and Statutory Control of Bureaucracy", American Journal of Political Science, Vol. 45, No. 2 
Huneeus, Carlos (1998) "Technocrats and Politicians in the Democratic Politics of Argentina (1983-95)". In: The Politics of Expertise in Latin America. New York: St. Martin's Press, INC.

Huneeus, Carlos (2000) "Technocrats and Politicians in Authoritarian Regime. The ODEPLAN Boys and the Gremialist in Pinochet's Chile", Journal of Latin American Studies $\mathrm{N}^{\circ} 32$

Iglesias, Enrique (2006) "El papel del Estado y los paradigmas económicos en América Latina." In: Revista de la CEPAL, 90

ILPES (2013) Aportes a la reflexión sobre las actividades del ILPES: antecedentes sobre el financiamiento y la gestión de los recursos. Brasilia: XIV Reunión del Consejo Regional de Planificación del ILPES

Jacint, Jordana and Carles Ramió (2010) "Delegation, Presidential Regimes, and Latin American Regulatory Agencies." In: Journal of Politics in Latin America, 2, 1,

Jaramillo, Juan Carlos et al. (1999) “The Political Economy of Exchange Rate Policy in Colombia". Inter-American Development Bank, Working paper

Jones, Gareth (2012) Organizational Theory, Design, and Change. Upper Saddle River: Prentice Hall

Juarez, Carlos (1993) "Trade and Development Policies in Colombia: Export Promotion and Outward Orientation, 1967-1992", Studies in Comparative International Development $\mathrm{Vol} .28, \mathrm{~N}^{\circ} 3$

Junta Nacional de Planificación y Coordinación Económica (1954) Informe Anual 1954-1955. Quito: Banco Central del Ecuador

Kaufman, Herbert (1976). Are Government Organizations Immortal? Washington: Brookings

Kelemen, Mihaela (2000) "Too much or too little ambiguity: The language of Total Quality Management", Journal of Management Studies 37

Kofas, Jon (2001) "The IMF, the World Bank, and U.S. Foreign Policy in Ecuador, 1956-1966", Latin American Perspectives: Issue 120, Vol. 28 No. 5 
Laegreid Per, and Koen Verhoest (2010). "Introduction: Reforming Public Sector Organizations". In: Governance of Public Sector Organizations. Proliferation, Autonomy and performance. Brussels: Palgrave Macmillan-International Institute of Administrative Sciences

Lauderbaugh, George (2012) The History of Ecuador. Santa Barbara: Greenwood

Larrea, Carlos and Liisa L. North (1997) "Ecuador: Adjustment Policy Impacts on Truncated Development and Democratisation", Third World Quarterly Vol. 18, No. 5

Leiva Lavalle, Jorge (2010) Instituciones e Instrumentos para el Planeamiento Gubernamental en América Latina. Brasilia: Instituto de Investigación Económica Aplicada-CEPAL

Levitsky, Steven and María Victoria Murillo (2008) "Argentina: From Kirchner to Kirchner", Journal of Democracy Vol. 19, No. 2

Levitsky, Steven and Maria Victoria Murillo (2010) "Continuity and Change in Weak Institutional Environment." Work in progress. New York: Columbia University

Lewis, David (2003) Presidents and the Politics of Agency Design. Stanford: Stanford University Press

Lichbach, Mark (1997) "Social Theory and Comparative Politics" In: Mark Irving Lichbach and Alan S. Zuckerman, eds., Comparative Politics. Rationality, Culture, and Structure. Cambridge: Cambridge University Press

Locke, E. A., D. Chah, S. Harrison, and N. Lustgarten (1989) "Separating the effects of goal specificity from goal level", Organizational Behavior and Human Decision Processes 43

Lora, Eduardo (2010) "La Situación Económica y Social Antes y Después de la Constitución de 1991". In: Consecuencias Imprevistas de la Constitución de 1991. Bogotá: Alfaomega-FEDESARROLLO

Lora, Eduardo, ed. (2007) The State of State Reform in Latin America. Washington: Inter-American Development Bank-Stanford University Press 
Loveman, Brian (1979) Chile, the Legacy of Hispanic Capitalism. Oxford: Oxford University Press

Lüders, R. (1998). “The Comparative Economic Performance of Chile: 1810-1995,” Estudios de Economía 25

Macey, Jonathan (1993). “Organizational Design and Political Control of Administrative Agencies," Journal of Law, Economics, and Organization, Vol 8, No 1

McCubbins, Matthew, Roger Noll and Barry Weingast (1987) "Structure and Process, Politics and Policy: Administrative Arrangements and the Political Control of the Agencies", Journal of Law Economics \& Organization 3

Mahoney, James (2000) "Path Dependency in Historical Sociology", Theory and Society, $\mathrm{N}^{\circ} 29$

Mahoney, James and Kathleen Thelen (2010) "A Theory of Gradual Institutional Change". In: Explaining Institutional Change. Ambiguity, Agency, and Power. Cambridge: Cambridge University Press

Mainwaring, Scott (1990) "Presidentialism in Latin America", Latin America Research Review, Vol. 25 No. 1

Mainwaring, Scott and Matthew Shugart (1997) "Presidentialism and Democracy in Latin America: Rethinking the Terms of the Debate." In: Presidentialism and Democracy in Latin America. Cambridge: Cambridge University Press

Majone, Giandomenico. (1997) "From the Positive to the Regulatory State: Causes and Consequences of Changes in the Mode of Governance", Journal of Public Policy, $17(2)$

Mallon, Richard and Juan Sourrouille (1975) Economic Policy Making in a Conflict Society: The Argentinean Case. Cambridge: Harvard University Press

Mallon, Richard (2000) The New Missionaries. Memoirs of a Foreign Adviser in LessDeveloped Countries. Cambridege: Harvard University Press

Martz, John (1988) "The Military in Ecuador: Policies and Politics of Authoritarian Rule". Occasional Paper Series $\mathrm{N}^{\circ} 3$. Albuquerque: The University of New MexicoLatin American Institute 
Martz, John (1972) Ecuador: Conflicting Political Culture and the Quest for Progress. Boston: The Allyn and Bacon Series in Latin American Politics

Martín-Mayoral, Fernando (2009) "Estado y mercado en la historia de Ecuador. Desde los años 50 hasta el gobierno de Rafael Correa", Nueva Sociedad No 221

Marcos, Palacios (2001) "Saber es Poder: El Caso de los Economistas Colombianos." In: De Populistas Mandarines y Otras Violencias. Bogotá: Editorial Planeta

Maxwell, Cameron, A (2009) "Latin America's Left Turns: beyond good and bad," Third World Quarterly, Vol. 30, No. 2

Mejía, Andrés, Vicente Albornoz, and Caridad Araujo (2007) "The political economy of the budget process: the case of Ecuador". Washington: Inter-American Development Bank, Country Studies Series, Working Paper CS-101

Mejía Acosta et al (2008) "Veto Players, Fickle Institutions, and Low-Quality Policies: The Policymaking Process in Ecuador. In: Policy Making in Latin America. How Politics Shapes Policies. Washington: Inter-American Development Bank-David Rockefeller Center

Meller, Patricio (1990) "Revisión del Proceso de Ajuste Chileno de la Década del 80". Colección de Estudios CIEPLAN №30

Moe, Terry (1989) "The Politics of Bureaucratic Structure". In: Can the Government Govern? Edited by John E Chubb and Paul E Peterson. Washington: The Brooking Institution Press

Moe, T. M. (1990a). "Political Institutions: The Neglected Side of the Story", Journal of Law, Economics, and Organization, 6(Special Issue)

Moe, T. M. (1990b). "The Politics of Structural Choice: Toward a Theory of Public Bureaucracy." In: Organization Theory: From Chester Bernard to the Present and Beyond. Edited by Oliver Williamson. New York: Oxford University Press

Moe, Terry and Scott A. Wilson (1994) "Presidents and the Politics of Structure" Law and Contemporary Problems 57

Moncada-Sánchez, José (1974) "La Evolución de la Planificación en el Ecuador." Nueva Sociedad: $\mathrm{N}^{\circ} 13$ 
Montecinos, Verónica (1993) “Economic Policy Elites and Democratic Consolidation." Working Paper \#191

Montecinos, Verónica (1997) "Economists in Political and Policy Elites in Latin America", in: The Post-1945 Internationalization of Economics. Durham: Duke University Press

Montecinos, Veronica (2009) "Economics: the Chilean History". In: Economists in the Americas. Cheltenham, Edward Elgar Publishing Inc.

Montecinos, Verónica and John Markoff (2009) Economists in the Americas. Cheltenham: Edward Elgar Publishing

Montúfar, Cesar (2000) La Reconstrucción Neoliberal. Febres Cordero o la Estatización del Neoliberalismo en Ecuador 1984-1988. Quito: Ediciones Abya-Yala

Morcillo, Pedro Pablo (2002) La Planeación en Colombia: Historia, Derecho y Gestión. Bogotá: Universidad Piloto de Colombia

Moreira, Carlos (2008) “El Estado Latinoamericano en el Último Medio Siglo: Crisis, Reformas, ¿Resurrección?" Conferencia INAP Guatemala - Maestría en Administración Pública

Murillo, Maria Victoria (2000) "From Populism to Neoliberalism: Labor Unions and Market Reforms in Latin America", World Politics Vol .52, No. 2

Muñoz Gomá, Oscar (1977) “Origenes Políticos y Económicos del Estado Empresarial en Chile". Estudios Cieplan 16

Navia, Patricio (2011) “El ministro más poderoso de Cristina K”. La Tercera, 12 de noviembre

Nef, Jorge (2003) "Public Administration and Public Sector Reform in Latin America." In: Handbook of Public Administration, London: Sage

Nolte, Detlef (2011) "Reformas Constitucionales en América Latina en Perspectiva Comparada: La Influencia de Factores Institucionales.” German Institute of Global and Area Studies

North, Douglas (1990) Institutions, Institutional Change and Economic Performance. Cambridge: Cambridge University Press 
Ocampo, José Antonio (1987) Historia Económica de Colombia. Bogotá: FEDESARROLLO-Siglo Veintiuno Editores

O'Donnell, Guillermo (1973) Modernization and Bureaucratic Authoritarianism: Studies in South American Politics. Berkeley: University of California

Oszlak, Oscar (2002) Redemocratization and the Modernization of the State: the Alfonsin Era in Argentina."In: Transitions from Authoritarianism: The Role of the Bureaucracy. London: Praeger ed.

Otero Prada, Diego (1985) Análisis de los mecanismos de planificación y del proceso de fijación de prioridades en el sector público de Argentina. Quito: FLACSO

Page, Scott (2006) "Path Dependence." Quarterly Journal of Political Science, N¹

Palacios, Marco (2001) "Saber es Poder. El Caso de los Economistas Colombianos." In: De Populistas, Mandarines y Violencias. Luchas por el Poder. Bogotá, Editorial Planeta

Parsons, Craig (2007) How to Map Arguments in Political Science. Oxford: Oxford University Press

Perry, Guillermo (1973) Desarrollo institucional de la planeación en Colombia. Bogotá: FEDESARROLLO

Peters, Guy (1992). "Government Reorganization: A Theoretical Analysis". International Political Science Review Vol. 13 No. 2

Pierson, Paul (2000) "Increasing Returns, Path Dependence, and the Study of Politics." The American Political Science Review Vol. 94, No 2

Pierson, Paul (2004) Politics in Time. History, Institutions, and Social Analysis. Princeton: Princeton University Press

Pinochet, Augusto (1975) Mensaje Presidencial. 11 de Septiembre 1974-11 de Septiembre 1975. Retrieved from memoriachilena.cl/602/w3-propertyvalue127440.html

Pollitt, Christopher, C. Talbot, Caulfield and A. Smullen (2004) Agencies. How Governments do Things through Semi-Autonomous Organizations. London: Palgrave 
Potash, Robert (1996) The Army and Politics in Argentina, 1962-1973: from Frondizi's Fall to the Peronist Restoration. Stanford: Stanford University Press

Primo Braga, Carlos (2006) "Import Substitution Industrialization in Latin America: Experience and Lessons for the Future" Paper prepared for a seminar in honor of Professor Werner Baer, held at the University of Illinois at UrbanaChampaign, December 1-2, 2006

Pyne, Peter (1977) “Presidential Caesarism in Latin America: Myth or Reality? A Case Study of the Ecuadorian Executive during the Presidency of José María Velasco Ibarra, 1960-1961", Comparative Politics Vol. 9, No. 3

Pyne, Peter (1975) "The Politics of Instability in Ecuador: The Overthrow of the President, 1961", Journal of Latin American Studies Vol. 7, No. 1

Rainey, Hal (2003) Understanding and Managing Public Organizations. Hoboken: Jossey-Bass

Renteria, Carolina (2008) "Cincuenta Años del DNP, Historia de una Construcción Colegiadas." In: 50 Años Departamento Nacional de Planeación. Bogotá: Departamento Nacional de Planeación

Rius, Andrés and Nicolas Van de Walle (2003) "Political Institutions and Economic Policy Reform." Document presented to Global Development Network: Understanding Reform

Rivera Ortiz, Angel Israel (1976) The Politics of Development Planning in Colombia. A PHD dissertation submitted to the Faculty of the Graduate School of State University of New York

Rolland, Vidar and Paul G. Roness (2009) "Mapping Organizational Change in the State: Challenges and Classifications." Paper presented at the International Workshop on 'Mapping State Administrations: Towards a Common European Research Agenda'

Rondinelli, Dennis (1978) "National Investment Planning and Equity Policy in Developing Countries: The Challenge of Decentralized Administration", Policy Sciences, 10, 45-74 
Roness, Paul (2007) "Types of State Organizations: Arguments, Doctrines and Changes Beyond New Public Management." In: Transcending New Public Management. The Transformation of Public Sector Reform. Christensen and P. Lægreid (eds). Aldershot: Ashgate Publishers.

Rosas, Luis Eduardo (1983) “La Planificación y la Política Macroeconomica”. In: La Planeación en Colombia 1958-1983. Bogotá: Departamento Nacional de Planeación

Salgado, Germánico (1979) 25 Años de Planificación. Quito: Junta Nacional de Planificación y Coordinación Económica

Salvador, Galo (1979) "La Junta Nacional de Planificación y sus Responsabilidades en el Desarrollo Económico y Social del Ecuador". In: 25 Años de Planificación. Quito: Junta Nacional de Planificación

Santos, Eduardo (1979) El Proceso de Planificacion en Ecuador. Contextos, influencias y dificultades. Quito: Universidad Alfredo Pérez Guerro, boletín no. 44

Sapelli, Claudio (2003) "The Political Economy of Import Substitution Industrialization. Documento de trabajo N0 257". Instituto de Economía. Santiago: Pontificia Universidad Católica de Chile

Scartascini, Carlos (2008) "Who's Who in the PMP: An Overview of Actors, Incentives, and the Roles they Play." In: Policy Making in Latin America. How Politics Shapes Policies. Washington: Inter-American Development Bank

Schneider, Ben Ross (1998) "The Material Basis of Technocracy: Investor Confidence and Neoliberalism in Latin America." In: The Politics of Expertise in Latin America. New York: Macmillan Press

Seawright, Jason and John Gerring (2008) "Case Selection Techniques in Case Study Research A Menu of Qualitative and Quantitative Options", Political Research Quarterly Vol. 61, No. 2

Sikkink, Kathryn (1993) "Las Capacidades y la Autonomía del Estado en Brasil y Argentina. Un Enfoque Neoinstitucionalista”. Desarrollo Económico, Vol. 32 No128

Skoopol, Theda (1995) “Why I am an Historical Institutionalist.” Polity 28

Silva, Eduardo (2007) “The Import Substitution Model: Chile in Comparative Perspective" Latin America Perspectives, vol. 34 No. 67 
Silva, Eduardo (1993) "Capitalist Coalitions, the State, and Neoliberal Economic Restructuring. Chile 1973-88", World Politics No 45

Silva, Patricio (1994) "State, Public Technocracy and Politics in Chile, 1927-1941". Bulletin of Latin American Research, vol. 13 No. 3

Silva, Patricio (1997) "Ascenso tecnocrático y democracia en América Latina", Nueva Sociedad No. 152 Noviembre-Diciembre

Silva, Patricio (2000) "State Capacity, Technocratic Insulation, and GovernmentBusiness Relations in South Korea and Chile". Santiago de Chile: FLACSO

Smith, William (1989) Authoritarianism and the Crisis of the Argentine Political Economy. Stanford: Stanford University Press.

Steinmo, Steven, Kathleen Thelen and Frank Longstreth (1992) Structuring Politics. Historical Institutionalism in Comparative Analysis. Cambridge: Cambridge University Press

Soms Garcia Esteban (2010) ODEPLAN/MIDEPLAN. Una Escuela Para el Cambio Social. Santiago de Chile. Santiago: Ministerio de Planificación

Sondrol, Paul (2005) “The Presidential Tradition in Latin America", International journal of Public Administration, vol. 28

Streeck, Wolfang and Kathleen Thelen, (2005) "Introduction: Institutional Change in Advance Political Economies." In: Beyond Continuity: Institutional Change in Advance Political Economies. Oxford: Oxford University Press

Taffet, Jeffrey (2007) Foreign Aid as Foreign Policy. The Alliance for Progress in Latin America. New York: Taylor \& Francis Group

Thelen, Kathleen (1999) "Historical Institutionalism in Comparative Politics". Annual Review of Political Science No 2

Thelen, Kathleen (2003) "How Institutions Evolve. Insights from Comparative Historical Analysis". In: Comparative Historical Analysis in the Social Sciences. Cambridge: Cambridge University Press

Thelen, Kathleen (2009) "Institutional Change in Advanced Political Economies". British Journal of Industrial Relations 47:3 
Tsebelis, George (2002) Veto Players: How Political Institutions Work. Princeton: Princeton University Press

Tsebelis, George and Eduardo Aleman (2005) "Presidential Conditional Agenda Setting in Latin America," World Politics, Vol. 57, No. 3

Urrutia, Miguel (1988) “The Changing Nature of Economic Planning in Colombia.” In: Development Planning in Mixed Economies. Hong Kong: The United Nations University

Valdés, Juan Gabriel (1995) Pinochet's Economists. The Chicago School in Chile. Cambridge: Cambridge University Press

Valenzuela, Arturo (2004) "Latin American Presidencies Interrupted", Journal of Democracy Vol. 15, No 4

Valenzuela, Samuel and Timothy Scully (1997) "Electoral Choices and the Party System in Chile: Continuities and Change at the Recovery of Democracy", Comparative Politics Vol. 29, $\mathrm{N}^{\circ} 4$

van Dijck, Pitou (1998) "The World Bank and the Transformation of Latin American Society". In: The Politics of Expertise in Latin America. London: Palgrave Macmillan

Vega-Moreno, Néstor (1971) Los Planes de Desarrollo. Su Coordinación dentro de la Subregión Andina. Quito: Junta Nacional de Planificación y Coordinación Económica

Vega-Moreno, Néstor (1979) “Logros de la Planificación Económica en Ecuador". In: 25 Años de Planificación. Quito: Junta Nacional de Planificación

Verhoest, Koen, et al (2010) Autonomy and Control of State Agencies. Comparing States and Agencies. Basingstoke: Palgrave Macmillan

Vicuña Izquierdo, Leonardo (1987) La Planificación en Ecuador. Quito: Banco Central del Ecuador-Corporación Editora Nacional

Waterston, Albert (1966) Development Planning. Lessons of Experience. London, Oxford University Press 
Weingast, Barry, Kenneth Shepsle, and Christopher Johnsen (1981) "The Political Economy of Benefits and Costs: A Neoclassical Approach to Distributive Politics", Journal of Political Economy 89

Weyland, Kurt (2002) The Politics of Market Reform in Fragile Democracies: Argentina, Brazil, Peru and Venezuela. Princeton: Princeton University Press

Weyland, Kurt (2007) Bounded Rationality and Policy Diffusion: Social Sector Reform in Latin America. Princeton: Princeton University Press

Wilson, J. Q. (1989) Bureaucracy: What Government Agencies Do and Why They Do It. New York: Basic Books.

Weiss, Janet and S. Piderit (1999) "The value of mission statements in public agencies", Journal of Public Administration Research and Theory 9

Williamson, Oliver (1975) Markets and Hierarchies. New York: Free Press

Wise, Carol (2003) Reinventing the State. Economic Strategy and Institutional Change in Peru. Ann Arbor: The University of Michigan Press.

Wood, Dan, and John Bohte (2004). "Political Transaction Costs and the Politics of Administrative Design", The Journal of Politics Vol. 66, No. 1

World Bank (2006) Appraisal of Public Investment: Chile. Knowledge Brief for Bank Staff

Wynia, Gary (1978) Argentina in the Postwar Era. Politics and Economic Policy Making in a Divided Society. Alburquerque: University of New Mexico Press

Wylde, Christopher (2011) "State, Society and Markets in Argentina: The Political Economy of Neodesarrollismo under Nestor Kirchner, 2003-2007", Bulletin of Latin American Research Vol. 30, No. 4

Yesilkagit, K. (2004) "The Design of Public Agencies: Overcoming Agency Costs and Commitment Problems", Public Administration and Development, 24 (2) 


\section{Samenvatting}

\section{De Veranderende Rol van de Centrale Planbureaus in Latijns-Amerika: Perspectief van een Vergelijkende Historische Analyse (1950-2013)}

Gedurende de afgelopen zestig jaar heeft het structurele ontwerp van de centrale planbureaus in Latijns-Amerika meerdere gedaantewisselingen ondergaan. Deze bureaus ontstonden aan het einde van de vijftiger jaren als antwoord op een ontwikkelingsstrategie die van de staat vereiste middels economische planning in een lange termijn bestuur voor de ontwikkeling te voorzien. Drie decennia later werden diezelfde bureaus omgevormd, geconfigureerd of opnieuw geimplementeerd om de doeleinden van een volledige andere ontwikkelingsstrategie te dienen. De planningsinstanties in deze landen begonnen functies uit te voeren die geschikt waren voor een vrije markt ontwikkelingsmodel, waardoor zij wegschoven van hun voorgaande focus op een naar binnen gerichte ontwikkelingsstrategie. Vervolgens, rond het jaar 2000, begon er voor de LatijnsAmerikaanse landen een wedergeboorte van de economische aanwezigheid van de staat, inclusief een nieuwe herstructurering van de economische planbureaus. Tussen deze drie verschillende strategiën voor economische en sociale ontwikkeling door, werden de planbureaus voortdurend toegewezen en geredirigeerd naar een breed scala van functies al naargelang dit noodzakelijk werd geacht. Wat verklaart het feit dat hetzelfde bureau, opgericht met de functie van het plannen van economische ontwikkeling, door de tijd heen regeringen met soms scherpe idieologische, economische en politieke verschillen heeft gediend? Welke karakteristieken heeft dit bureau en wat is zijn aantrekkingskracht waardoor het in staat is gedurende zo'n lange periode stand te houden?

Het onderliggende onderzoek in deze dissertatie probeert een antwoord te geven op deze vragen door de belangrijke institutionele variabelen te beschrijven en te analyseren die van invloed zijn geweest op de veranderende rol van de LatijnsAmerikaanse centrale planbureaus gedurende de afgelopen zestig jaar.

De keuze van de planningsinstantie als onderwerp van studie is gebaseerd op het feit dat deze bureaus een unieke positie hebben gehad binnen de publieke sector in Latijns-Amerika, waarbij zij een echte instelling werden. Samen met de centrale banken en de ministeries van financiën, onderscheidden deze drie instellingen zich als "efficiency pockets" ten opzichte van de overheidsadministratie. Echter, terwijl de eerste twee, ongeacht het economische model ter plekke, noodzakelijk zijn om het monetaire en fiscale beleid te beheren voor de macroeconomische stabiliteit, kon de planninginstantie gemakkelijk overbodig worden, in het bijzonder in het licht van de duidelijke vermindering van de staatsinterventie. 
Theoretisch werk over organisatorisch institutionalisme zoals de structureleinstrumentale, cultureel-institutionele, taakspecifieke en institutionele klimaat perspectieven, is krachtig voor de verklaring van veranderingen in specifieke historische momenten in de Latijns-Amerikaanse planning organisaties. De empirische data suggereren echter dat het belangrijk is een dergelijke analyse aan te vullen met conceptuele instrumenten die de logica van de endogene en geleidelijke organisatorische gedaantewisseling vastleggen. Daarom worden deze perspectieven aangevuld met de conceptuele instrumenten van Mahoney and Thelen (2010) die de logica van endogene en geleidelijke verandering vastleggen.

Case studies zijn cruciaal voor onderhavig onderzoek. Deze nemen de vorm aan van een gedetailleerd relaas dat pretendeert te belichten hoe een organisatorische gedaantewisseling tot stand kwam. Gezien in deze context is dit onderzoek gebaseerd op de technieken die onder het label van "process- tracing" vallen door bewijsmateriaal uit de case studies te gebruiken waardoor het mogelijk wordt de verondertelde causale mechanismen vast te stellen die de veranderingen in de Latijns-Amerikaanse centrale planning verklaren. Voor elk der genoemde theoretische benaderingen, deduceert het onderzoek de impliciete causale mechanismes door theoretische verklarende variabelen en organisatorische gedaantewisseling met elkaar te verbinden. Het empirische bewijs dat gebruikt werd om vast te stellen of de waarneembare gevolgen aanwezig waren en funcioneerden zoals verwacht werd is gebaseerd op diepte-veldonderzoek in Argentinië, Ecuador, Chili en Colombia.

De kern van het onderzoeksresultaat laat zien dat het presidentiële regeersysteem dat Argentinië, Ecuador, Chili en Colombia heeft gekarakteriseerd tesamen met de structurele opstelling van de centrale planbureaus mogelijk maakten wat Mahoney and Thelen (2010) identificeren als een "conversie" modus van institutionele verandering. Ondanks het feit dat externe schokken en druk krachtige stimuli zijn geweest voor veranderingen in de organisatorische opstelling van de planninginstanties in deze landen, zijn de organisatorische gedaanteverwisselingen consequent het resultaat geweest van zestig jaar herschikking van de doelen, functies en toepassingen van de planninginstanties door de presidenten. 


\section{MGSoG Dissertation series}

Cheng Boon Ong

Ethnic Segregation in Housing, Schools and Neighbourhoods in the Netherlands

MGSoG Dissertation Series, nr 45 (2014)

Luciana V. Cingolani

Bureaucracies for Development: Oxymoron or Reality?

Studies on State Capacity in Challenging Governance Contexts

MGSoG Dissertation Series, nr 44 (2014)

Carlos Cadena Gaitán

Green Politics in Latin American Cities - Sustainable Transport Agendas

MGSoG Dissertation Series, nr 43 (2014)

Katie Kuschminder

Female Return Migration and Reintegration Strategies in Ethiopia

MGSoG Dissertation Series, nr 42 (2014)

Metka Hercog

Highly-Skilled Migration and New Destination Countries

MGSoG Dissertation Series, nr 41 (2014)

Margaret Agaba Rugadya

Can Remittances Influence the Tenure and Quality of Housing in Uganda?

MGSoG Dissertation Series, nr 40 (2014)

Ilire Agimi

New Governance Under Limited Statehood

The Case of Local Government Reform in Kosovo

MGSoG Dissertation Series, nr 39 (2014)

Kristine Farla

Empirical Studies on Institutions, Policies and Economic Development

MGSoG Dissertation Series, nr 38 (2013)

Marina Petrovic

Social Assistance and Activation in the Pursuit of Happiness:

Shedding New Light on Old Policy Solutions to Social Exclusion

MGSoG Dissertation Series, nr 37 (2013) 
Laura Torvinen

Assessing Governance Assessments; The Case of Mozambique

Governance Assessments in the Context of Aid Effectiveness Discourse

MGSoG Dissertation Series, nr 36 (2013)

Biniam Egu Bedasso

Institutional Change in the Long Shadow of Elites

Essays on Institutions, Human Capital and Ethnicity in Developing Countries

MGSoG Dissertation Series, nr 35 (2013)

Sepideh Yousefzadeh Faal Deghati

Childhoods Embargoed

Constructing and Reconstructing Multidimensional Child Poverty in Iran 1984-2009

MGSoG Dissertation Series, nr 34 (2013)

Robert Bauchmüller

Investing in Early Childhood Care and Education:

The Impact of Quality on Inequality

MGSoG Dissertation Series, nr 33 (2013)

Martin Rehm

Unified Yet Separated

Empirical Study on the Impact of Hierarchical Positions within Communities of Learning

MGSoG Dissertation Series, nr 32 (2013)

Dorcas Mbuvi

Utility Reforms and Performance of the Urban Water Sector in Africa

MGSoG Dissertation Series, nr 31 (2012)

Lina Salanauskaite

Distributional Impacts of Public Policies:

Essays in Ex-Ante and Ex-Post Evaluation

MGSoG Dissertation Series, nr 30 (2012)

Esther Schüring

To Condition or not - is that the Question?

An Analysis of the Effectiveness of Ex-Ante and Ex-Post Conditionality in Social Cash

Transfer Programs

MGSoG Dissertation Series, nr 29 (2012) 
Joe Abah

Strong Organisations in Weak States

Atypical Public Sector Performance in Dysfunctional Environments

MGSoG Dissertation Series, nr 28 (2012)

Zina Samih Nimeh

Social Citizenship Rights: Inequality and Exclusion

MGSoG Dissertation Series, nr 27 (2012)

Lenka Eisenhamerová

Legitimacy of 'Humanitarian Military Intervention'

MGSoG Dissertation Series, nr 26 (2011)

Sonila Tomini

Informal Payments for Health Care Services in Albania

MGSoG Dissertation Series, nr 25 (2011)

Jinjing Li

Dynamic Microsimulation in Public Policy Evaluation

MGSoG Dissertation Series, nr 24 (2011)

Aziz Atamanov

Rural Nonfarm Employment and International Migration as Alternatives to Agricultural

Employment:

The Case of Kyrgyztan

MGSoG Dissertation Series, nr 23 (2011)

Frieda Vandeninden

Poverty Alleviation: Aid and Social Pensions

MGSoG Dissertation Series, nr 22 (2011)

Juliana Nyasha Tirivayi

The Welfare Effects of Integrating AIDS Treatment with Food Transfers:

Evidence from Zambia

MGSoG Dissertation Series, nr 21 (2011)

Agnieska Ewa Sowa

Who's Left Behind? Social Dimensions of Health Transition and Utilization of Medical

Care in Poland

MGSoG Dissertation Series, nr 20 (2011) 
Emmanaouil Sfakianakis

The Role of Private Actors in the Provision of Public Goods with Applications to Infrastructure and Financial Stability

MGSoG Dissertation Series, nr 19 (2011)

Siu Hing Lo

White Collars Green Sleeves

An Interonganizational Compariso of Deteminants of Energie-Related Behaviors among Office Workers

MGSoG Dissertation Series, nr 18 (2011)

Treena $\mathrm{Wu}$

Constraints to Human Capital Investment in Developing Countries:

Using the Asian Financial Crisis in Indonesia as a Natural Experiment

MGSoG Dissertation Series, nr 17 (2011)

Henry Espinoza Peña

Impact Evaluation of a Job-Training Programme for Disadvantaged Youths:

The Case of Projoven

MGSoG Dissertation Series, nr 16 (2011)

Florian Tomini

Between Family and Friends

Understanding the Interdependency of Private Transfers

MGSoG Dissertation Series, nr 15 (2010)

Michał Polalowski

The Institutional Transformation of Social Policy in East Central Europe:

Poland and Hungary in comparative and historical perspective

MGSoG Dissertation Series, nr 14 (2010)

Maha Ahmed

Defining, Measuring and Adressing Vulnerability:

The Case of Post Conflict Environments

MGSoG Dissertation Series, nr 13 (2010)

Pascal Beckers

Local Space and Economic Success

The role of spatial segregation of migrants in the Netherlands

MGSoG Dissertation Series, nr 12 (2010) 
Victor Cebotari

Complicting Demands in Ethnically Diverse Societies

Ethnopolitical Contention and Identity Values in Europe

MGSoG Dissertation Series, nr 11 (2010)

Dennis Gyllensporre

Competing and Complementary Perspectives on the EU as a Crisis Management Actor:

An Examination of the Common Security and Defence Policy through the Lenses of

Idealism and Realism

MGSoG Dissertation Series, nr 10 (2010)

Judit Vall Castello

Business Cycle and Policy Effects on Labour Market Transitions of Older and Disabled Workers in Spain

MGSoG Dissertation Series, nr. 9 (2010)

Keetie Roelen

False Positives or Hidden Dimentions: the definition and measurement of child poverty

MGSoG Dissertation Series, nr. 8 (2010)

Denisa Maria Sologon

Earning Dynamics in Europe

MGSoG Dissertation Series, nr. 7 (2010)

Melissa Siegel

Money and Mobility: Migration and Remittances

MGSoG Dissertation Series, nr. 6 (2010)

Jessica S. Hagen-Zanker

Modest Expectations: Causes and effects of migration on migrant households in source countries

MGSoG Dissertation Series, nr. 5 (2010)

Mirtha R. Muniz Castillo

Human Development and Autonomy in Project Aid: Experiences from four

bilateral projects in Nigaragua and El Salvador

MGSoG Dissertation Series, nr. 4 (2009)

Christiane Arndt

Governance Indicators

MGSoG Dissertation Series, nr. 3 (2009) 
Britta Augsburg

Microfinance - Greater Good or Lesser Evil?

MGSoG Dissertation Series, nr. 2 (2009)

Geranda Notten

Measuring and Managing Poverty Risks

MGSoG Dissertation Series, nr. 1 (2008) 